'To the curious enquirer': depictions of Pacific peoples in popular illustrated books from Paris and London c. $1775-1810$

\title{
Vivienne Morrell
}

A thesis submitted to the Victoria University of Wellington in fulfilment of the requirements for the degree of Master of Arts in Art History

Victoria University of Wellington 2010 


\section{Contents}

Abstract iii

Acknowledgements

Chapter 1 Introduction: curiosity and the exotic 1

Chapter 2 The genres: encyclopaedias, cosmographies, and costume books 21

Chapter 3 Reading the frontispieces: the four parts of the world 34

Chapter 4 Inventing Oceania for the costume books 46

$\begin{array}{lll}\text { Chapter } 5 & \text { Costume and custom in illustrated encyclopaedias } & 69\end{array}$

Chapter 6 Conclusions: what the 'curious enquirer' found in the

illustrated encyclopaedias $\quad 92$

$\begin{array}{ll}\text { List of illustrations } & 101\end{array}$

$\begin{array}{ll}\text { Illustrations } & 111\end{array}$

$\begin{array}{ll}\text { Bibliography } & 174\end{array}$ 


\section{Abstract}

This study considers a range of illustrated encyclopaedias published in London and Paris in the late eighteenth and early nineteenth centuries depicting peoples of the Pacific or Oceania. Using a framework of curiosity, exoticism, and costume iconography, as well as considering relevant contemporary developments, I argue that, despite the widespread appeal to 'curiosity', the books reveal a fairly superficial interest, at a popular level, in other peoples: one that is mainly interested in contrasting 'civilised' Europe with less civilised or 'savage' others. The genres to which these books belonged developed in the sixteenth century, and the books considered in this study followed their genre traditions, fitting the 'new discoveries' of Oceania into these existing traditions. The frontispieces set the tone of the books, and embodied moral value judgements revealing European views of political, social and economic relations between Europe and other peoples and countries at that time. They were also following an iconographic tradition set down much earlier and generally failed to acknowledge recent events that challenged these prevailing views. I consider how the images of Oceanic peoples in the French costume books were developed (or as I argue 'invented') from the source material, which was mainly images in the published accounts of Captain Cook's three voyages. In inventing images designed to please the eye, the sources chosen reveal the prejudices and expectations of European readers. But how were the 'new' Oceanic peoples incorporated into these books? By seeing Oceanic peoples as part of America it was easy to fit them into existing prejudices about 'savages' and into existing pictorial conventions for depicting 'savages'. For an audience expecting to see 'savages' wearing grass skirts and feather headdresses these images would have appeared 'authentic'. My study will highlight more popular views rather than the views of philosophers, or the voyagers' accounts, which understandably have been given more academic attention. These books are overlooked today because they are derivative and their images are not necessarily ethnographically accurate; yet they were popular in their time. They represent a conservative Eurocentric viewpoint and their inclusion of new material from Oceanic voyages did not challenge these views. Images and texts such as these likely reinforced European views of their own superiority and made it easy to justify missionary activity and colonisation in various parts of the world, particularly Oceania. 


\section{Acknowledgements}

I would firstly like to thank my supervisor, David Maskill, for his helpful suggestions, comments on draft chapters, and support. Thanks also to Pippa Wisheart, art history department administrator and Annie Mercer, School Manager, School of Art History, Classics and Religious Studies, and other art history staff and post-graduate students for discussions and support. Roger Collins of Dunedin also helpfully suggested additional books.

Most of the books used in this study were sourced from the Alexander Turnbull Library, Wellington and I would like to acknowledge the help of Dr Ruth Lightbourne, Special Printed Collections librarian, in locating and suggesting additional material. My research would have required many more visits to the library were it not for the recent policy allowing researchers to take their own digital photographs, for which I am grateful. The images in this thesis reproduced from books in the Turnbull library are my own photographs. I also looked at a copy of Grasset de Saint-Sauveur's print (Tableau of discoveries of Cook and La Pérouse) at the Museum of New Zealand Te Papa Tongarewa, and thank Tony Mackle, Collection Manager Prints and Drawings, for access to this.

I also undertook some research in Australia - at the State Library of New South Wales, Sydney; National Library of Australia (NLA), Canberra and National Gallery of Australia (NGA), Canberra. I would like to thank staff from those institutions, in particular Rose Montebello at the NGA for arranging access for me to see the Dufour wallpaper in storage and Nick Nicholson for providing photographs of the wallpaper; and Sylvia Carr at the NLA for suggesting additional material in their collection. All these institutions also allowed me to take photographs, some of which are reproduced here.

Lastly I would like to thank my husband, Mark MacCallum, and friends for their patience and support. 


\section{Chapter 1 - Introduction: curiosity and the exotic}

To know the world from Home you need not Stray;

Sit at your Ease, and ev'ry Clime Survey:

Here Empires, Kingdoms, States, and Realms are shown

Men, Manners, Customs, Arts and Laws made known:

Here ev'ry Page your Wonder shall excite,

And give Improvement, while it gives Delight. ${ }^{1}$

The entertainment derived from the perusal of this work is not less than the advantages, as it extends to men of letters ... to politicians ... to officers, military and naval, as informing them of the state of countries ... to naturalists ... to merchants and traders, as assisting them in taking prudent measures for the advancement and circulation of commerce; and to the curious enquirer, to gratify his desire for universal knowledge. ${ }^{2}$

The 'curious enquirer' or 'curiosity' is widespread in the travel literature of the later eighteenth century. Curiosity played a crucial role in shaping knowledge. It was,

nevertheless, a term with moral overtones. Other countries, or the 'exotic', were among the typical objects of that curiosity. This study analyses a number of illustrated encyclopaedias produced in London and Paris from approximately 1775 to 1810 that presented these other worlds to a European audience. These were not first-hand travel accounts, but synthesised such accounts and a variety of other sources. My main focus will be images of peoples of the 'South Seas' (as the Pacific / Oceania was generally called in the eighteenth century), but I will consider these in the context of the books as a whole. As the above quotations show, these books aimed to both entertain and inform. To help analyse how 'the world' (its places and peoples) was understood by that audience, notions of 'curiosity', and 'exoticism' provide a useful framework. Brief consideration of contemporary events, philosophical ideas, and social climate will also be necessary to place the books in their historical contexts, and to identify possible causes of changes over the 35-year time period. Images of Oceanic peoples in these illustrated encyclopaedias in the late eighteenth and early nineteenth centuries conformed to certain pictorial conventions and genre traditions that ultimately tell us more about Europeans' views of themselves than about the Pacific. I

\footnotetext{
${ }^{1}$ Charles Middleton, A new and complete system of geography, London: J. Cooke, 1777, 2 vols, quotation on title page of vol. 1 .

${ }^{2}$ Thomas Bankes, New, royal and authentic system of universal geography, London: C. Cooke, 1790, Address to the reader, unpaginated.
} 
argue that images in these encyclopaedias often 'tell' a different 'story' from the text and were just as concerned to 'please the eye' as to present accurate information. What does this tell us about the audience for these books? Despite the popularity of the travel genre and widespread appeals to 'curiosity', I believe that European interest in others was fairly superficial; it was mainly a way of escaping into the 'exotic' and comparing other societies with one's own - and, for readers of these encyclopaedias, benefiting from the comparison. Notions of curiosity, used so often in these books, encapsulate this desire for restless novelty through appeals to the senses.

An engraved frontispiece to a 1713 book made in Augsburg shows a Pilgrim accompanied by Devotion and Curiosity - Devotion is a veiled and barefoot woman, eyes downcast, carrying a cross and bible, following behind the Pilgrim. Curiosity is a welldressed, attractive, woman who looks directly at the Pilgrim and points the way (fig. 1). ${ }^{3}$ Curiosity is clearly a temptation that may lead a man astray. Lorraine Daston and Katharine Park consider the relationship between 'wonder' and 'curiosity', arguing that the positive or negative connotations of the two words completely reversed over several centuries. ${ }^{4}$ Whereas 'wonder' was earlier seen in a positive light (for example, the wonders of God's creation) and 'curiosity' was viewed as a sin (related to the Fall of Adam and Eve and therefore lust and pride), by the mid-seventeenth century the two were more equal, and by the mid-eighteenth, curiosity was viewed more positively than wonder. The authors discuss an interesting example of a 1736 Parisian sale catalogue for exotic shells - the advertisement appealed to the "naturalists who exercised the recreation of the mind" (preferring their shells natural) and the curieux who sought "recreation of the eye" (preferring polished shells). ${ }^{5}$ This suggests the curious were more likely to be tempted by the senses and their interests were not quite the same as those of a scientist.

Daston and Park consider that by the mid-eighteenth century curiosity had lost its connotations of 'desire' and cite as evidence the French Encyclopédie (published 17511772), which praised the "noble curiosity" that "demanded continuous work and

\footnotetext{
${ }^{3}$ Conrad Hietling, Peregrinus affectuose per terram sanctam et Jerusalem a devotione et curiositate conductus, Augsburg, 1713. Illustrated as the frontispiece in Neil Kenny, The uses of curiosity in early modern France and Germany, Oxford \& New York: Oxford University Press, 2004. Reproduced by permission.

${ }^{4}$ Lorraine Daston and Katharine Park, Wonders and the order of nature 1150-1750, New York: Zone Books, 2001.

5 ibid, p. 325.
} 
application". ${ }^{6}$ However, I believe it is still used in contradictory ways into the late eighteenth century. In 1750, Jean-Jacques Rousseau (1712-1778) characterised "vain curiosity" as a vice, while Samuel Johnson (1709-1784) could declare it to be "one of the permanent and certain characteristics of a vigorous mind" (1751). ${ }^{7}$ Edmund Burke (17291797), writing in On the sublime (1757), said:

By curiosity, I mean whatever desire we have for, or whatever pleasure we take in novelty ... But as those things which engage us merely by their novelty, cannot attach us for any length of time, curiosity is the most superficial of all the affections ... it has an appetite which is very sharp, but very easily satisfied; and it has always an appearance of giddiness, restlessness and anxiety. ${ }^{8}$

While some educated gentlemen and scientists might claim that curiosity was a disinterested pursuit of knowledge, Johann Reinhold Forster (1729-1798), for example, on James Cook's (1728-1779) second world voyage also makes clear that the sailors were collecting great quantities of 'curiosities' to sell. ${ }^{9}$ Forster characterised his curiosity as for the benefit of the government and the public, while the sailors thought only of private benefit, but commerce (whether Government-supported or private) was never far behind curiosity. It was an ambiguous term in another way too - reactions in England to revelations of sexual contact between the crew and Tahitian women in the official account of Cook's first voyage included satirical poems and caricatures - thus calling into question the ostensibly scientific purpose of the voyage. Even if curiosity did become more acceptable, the acquisition of knowledge was not without moral connotations. As Nicholas Thomas asserts, in eighteenth-century travel accounts:

...that the nature of curiosity is not fixed but morally slippery, that the legitimacy of curious inquiry is uncertain, and that this area of semantic conflict is directly associated with responses to ethnographic specimens, since 'curiosities' were frequently characterized as being 'curious' and as arousing the 'curiosity' of people for whom they were exotic. ${ }^{10}$

\footnotetext{
6 ibid, p. 327.

${ }^{7}$ Rousseau quotation from Kenny, 2004, p. 334; and Johnson quotation from Peter Harrison, 'Curiosity, forbidden knowledge, and the reformation of natural philosophy in early modern England', Isis, 92(2), June 2001, p. 288.

${ }^{8}$ Edmund Burke, A philosophical enquiry into the origin of our ideas of the sublime and beautiful [1757], Eighteenth-century collections online, VUW library, $2^{\text {nd }}$ ed 1759, accessed 12 October 2009, pp. 41-42.

${ }^{9}$ Nicholas Thomas, 'Licensed curiosity: Cook's Pacific voyages', in John Elsner and Roger Cardinal (eds), The cultures of collecting, Melbourne \& London: Melbourne University Press, 1994, p. 135. Curiosity developed this meaning, i.e. as an object of interest, from the mid-seventeenth century in English (OED).

10 ibid, p. 122.
} 
Neil Kenny also disputes the view that curiosity was solely a positive term by the mid-eighteenth century, and argues that its uses were various and often contradictory, but he believes the point of invoking curiosity was almost always to regulate knowledge or behaviour, and under what circumstances. ${ }^{11}$ Forster's distinction between his enlightened (good) curiosity and that of the greedy sailors (bad) is a case in point. And, as might be expected, curiosity was used very differently when attributed to men or women - mostly it was male curiosity that became more acceptable in the eighteenth century. The contradictory uses of women's curiosity are shown in the popular Rev. James Fordyce's Sermons to young women (1775) - on one occasion a distinction is drawn between "a laudable inquisitiveness and an improper curiosity", in another "female curiosity" is said to have been "justly a topic of satire"; yet he recommends young women read books of voyages and travels, as: "How amusing to curiosity! How enlarging to our prospects of mankind!". ${ }^{12}$ An illustration of the allegory of Curiosity from one of the few English eighteenth-century costume books shows a pretty young woman with motifs of eyes and ears decorating her skirt (fig. 2). ${ }^{13}$ Notably, a similar motif was used in the so-called Rainbow portrait of Queen Elizabeth I (c.1600-03) which, as Roy Strong shows, was based on a Regione di stato figure in Cesare Ripa's Iconologia and implies a head of state who hears and sees many things through her servants. ${ }^{14}$ Barbara Benedict believes that the response of many writers and cultural critics to the new prominence of women in the eighteenth century, and their threat to established social hierarchies, was to revive biblical indictments against women's curiosity as impertinent, thus trying to regulate or control it and them. ${ }^{15}$

The extent to which curiosity was directed at useful purposes was a subject of debate. It was generally not a desire for all knowledge - its typical objects of study were the

${ }^{11}$ Kenny, 2004, p. 1

${ }^{12}$ Rev. James Fordyce, Sermons to young women, (a new edition), 2 vols, 1775, Eighteenth-century collections online, VUW library, accessed 21 August 2008, quotations from vol. 1, p. 165, vol. 2, p. 62, vol. 2 , p. 11. The popularity of his books can be gauged by noting that the $12^{\text {th }}$ edition was published in 1800 (and also in America).

${ }^{13}$ In A collection of the dresses of different nations, antient and modern ..., 4 vols, London: Thomas Jefferys, 1757-72. Eighteenth-century collections online, VUW Library, accessed 4 September 2008. From Gale. Eighteenth Century Collections Online. () Gale, a part of Cengage Learning, Inc. Reproduced by permission. www.cengage.com/permissions.

${ }_{15}^{14}$ Roy Strong, Gloriana: the portraits of Queen Elizabeth I, London: Pimlico, 2003, pp. 157-161.

${ }^{15}$ Barbara M. Benedict, Curiosity: a cultural history of early modern inquiry, Chicago \& London: Chicago University Press, 2001, p. 54. 
rare, the novel, and the exotic. Some writers associated the non-utility of curiosity with a praiseworthy disinterestedness. ${ }^{16}$ On the other hand, the philosopher Gottfried Leibniz (1646-1716) in founding a Prussian Academy in 1700 wanted to focus on agriculture, manufacture, commerce, etc, and avoid 'useless curiosities' and 'mere curiosity'. ${ }^{17}$ The notion of curiosity used in later eighteenth-century exploration accounts tends to separate the apparently disinterested pursuit of knowledge from the implications of discovery for the 'interested' processes of commerce and colonialism. ${ }^{18}$ Each of Cook's voyages had an important scientific mission, yet commerce was also an important consideration, especially for the second and third voyages (respectively, finding - or disproving the existence of the Southern Continent; and searching for a northwest passage that, if it existed, would greatly reduce the sailing time from Europe to the Pacific Ocean and the East). Margaret Hunt sees in English travel narratives a close link with commercial objectives. In discussing some of the advice books written over the course of the eighteenth century on things travellers should look for, she says: "travel writing merged seamlessly at a very early stage in Britain's imperial history with a discourse of profitability, labor efficiency, and national prosperity". 19

Curiosity was seen by some writers as one marker of civilisation and therefore lacking in 'savages'. The philosopher Adam Smith believed the 'savage' had no use for human curiosity and therefore did not experience wonder which is the source of philosophical inquiry. ${ }^{20}$ Captain Cook noted the apparent lack of curiosity (because of a lack of interest in European goods) in some Oceanic peoples as a factor that in his view put them on a lower level in their 'progress' towards 'civilisation' than those peoples who were interested in trading. Similarly, by 1777, he could detect no inclinations in the Queen Charlotte Sound New Zealanders towards 'progress' because they did not attempt to improve their

\footnotetext{
${ }^{16}$ Daston and Park, p. 309.

${ }^{17}$ Neil Kenny, 'The metaphorical collecting of curiosities in early modern France and Germany', in Curiosity and wonder from the Renaissance to the Enlightenment, Robert J. W. Evans and Alexander Marr (eds), Aldershot \& Burlington: Ashgate, 2006, p. 57.

${ }^{18}$ Noel Elizabeth Currie, Constructing colonial discourse: Captain Cook at Nootka Sound, 1778, Montreal: McGill-Queen's University Press, 2005, p. 49.

${ }^{19}$ Margaret Hunt, 'Racism, imperialism, and the traveler's gaze in eighteenth-century England', The Journal of British Studies, 32(4), October 1993, p. 351.

${ }^{20}$ Anthony Pagden, European encounters with the new world: from Renaissance to Romanticism, New Haven \& London: Yale University Press, 1993, p. 151.
} 
knowledge, "nor are they remarkably curious either in their observations or enquiries". ${ }^{21}$

On the other hand, although curiosity was aroused by the visits of Ma ' $\mathrm{i}$ ('Omai') to

England and Ahutoru to Paris, as Louis-Antoine de Bougainville (1729-1811) put it, this was a 'sterile curiosity' - the interest was not so much in their countries, societies or even their point of view, but in their reactions to the host country. The novelist Frances Burney (1752-1840) wrote of one of her meetings with Ma' $i$ : "as we are totally unacquainted with his country, connections, and affairs, our conversation ... consisted wholly in questions of what he had seen here". ${ }^{22}$ This is despite the fact that her brother James Burney (17501821) was a lieutenant on the ship that brought Ma'i to England, recorded information he learnt from $\mathrm{Ma}^{6} \mathrm{i}$ in his journal and sometimes acted as his interpreter in England.

'Exotic' objects and people were among the typical objects studied by the curious. The term 'exotic' was used in the eighteenth century, but in England, according to Christa Knellwolf, it was mainly used to describe botanical specimens. ${ }^{23}$ However, the Oxford English Dictionary provides some non-botanical uses of 'exotic' in the eighteenth century, such as "the Italian Opera, an exotick and irrational entertainment" (1779-81). ${ }^{24}$ David Culpin traces the use and meaning of the term exotique in France from the late seventeenth century. ${ }^{25}$ At that time it meant an intellectual curiosity toward the 'foreign', but conveyed "none of our modern sense of the imaginative excitement in response to foreignness ...rather, that connotation was available in the word curieux". Exotique could not incorporate imaginative excitement until a positive attitude toward the imagination developed - Culpin believes the French translation of Mille et une nuits [Arabian nights] in the early eighteenth century was above all others what, "in the European mind, so decisively associated the exotic with a new imaginative excitement". ${ }^{26}$

In the eighteenth century it was fashionable to display exotic objects, although often these were adapted to suit European taste by combining them with European decorative

\footnotetext{
${ }^{21}$ Harriet Guest, Empire, barbarism, and civilisation: James Cook, William Hodges, and the return to the Pacific, Cambridge: Cambridge University Press, 2007, p. 137.

${ }^{22}$ Guest, 2007, pp. 152-155 for the English reaction to Ma'i; and Pagden, 1993, p. 32 for French reaction to Ahutoru. Bougainville brought Ahutoru to Paris from Tahiti.

${ }^{23}$ Christa Knellwolf, 'The exotic frontier of the imperial imagination', Eighteenth-century life, 26(3), Fall 2002, p. 10.

${ }^{24}$ Oxford English Dictionary online, $2^{\text {nd }}$ ed., 1989, VUW Library, accessed 4 August 2008.

${ }^{25}$ David J. Culpin, 'The exotic and the creative imagination in the 1690s: Charles Perrault's Les hommes illustres', Eighteenth-century life, 26(3), Fall 2002, pp. 31-44.

${ }^{26}$ ibid, p. 43.
} 
elements. As well as markers of the owner's wealth and status, they declared a person to be of 'good' taste. In this context, the exotic usually contained only pleasing or amusing scenes. There was, however, also a fascination with reading about 'savage' practices, such as cannibalism; therefore the exotic could encompass both desire and threat. Yet there did not seem to be a real desire to know these 'others' in depth - once some 'new' peoples were 'discovered', interest in the old quickly waned - so, the South Seas replaced America in the European imagination in the late eighteenth century. While voyage literature was popular, the rewriting of it to suit particular European interests was even more popular. ${ }^{27}$ As noted above, limited interest is also demonstrated in the reception shown in 'exotic' visitors to London and Paris over the course of the eighteenth century. As Katharine Fullagar argues: "If Omai represented the apex of British interest in New World visitors, the decline after his visit was surprisingly steep". ${ }^{28}$ Fullagar links this interest (or lack of) to key debates and social changes going on in England at the time, and whether 'savages' could be useful as models of "alternate ways of being". ${ }^{29}$

Writers from various disciplines have used theories of 'exoticism' to interpret the ways Europeans have viewed 'others' especially in and since the eighteenth century. I believe these can provide a useful framework for my study, but it is worth noting that 'exoticism' was not a term used in the eighteenth century. The earliest use given in the Oxford English Dictionary is for 1827 where it was used in a negative way - "tainted with many exoticisms and other defects"; and it appeared in French around $1845 .^{30}$ Not all modern writers and theorists have meant the same thing by its use, although there are commonalities. George Rousseau and Roy Porter mean by exoticism "all those constellations of ideas and human practices that thrive on the remote, the strange, and the unfamiliar for their essential vitality". 31 They see the exotic as a way people of the eighteenth century measured their own society and values; so a way of making comparisons

\footnotetext{
${ }^{27}$ Jane Elliott, 'The choosers or the dispossessed? Aspects of the work of some French eighteenth-century Pacific explorers', in Annick Foucrier (ed), The French and the Pacific world, $17^{\text {th }}-19^{\text {th }}$ centuries, Aldershot \& Burlington: Ashgate, 2005, pp. 284-285.

${ }^{28}$ Katharine Fullagar, 'Savages and moderns: the New World in Britain, $1710-\mathrm{c} 1800$ ', PhD thesis, University of California, Berkeley, 2004, p. 6, partial access from ProQuest Dissertations and Theses, VUW Library, accessed 24 May 2008.

${ }^{29}$ Ibid: abstract (summary).

${ }^{30}$ Oxford English Dictionary online; VUW Library, accessed 4 August 2008; Le Grand Robert de la Langue Francaise, $2^{\text {nd }}$ ed., Paris: Dictionnaires le Robert, 2001.

${ }^{31}$ George Rousseau and Roy Porter, (eds), Exoticism in the Enlightenment, Manchester: Manchester University Press, 1990, p. vi.
} 
with other societies. According to them, the exotic became a "code-word for modes of belief and behaviour which specifically transgressed the norms of Christian, civilised, rational Europe". ${ }^{32}$ It could be both inviting and threatening and provide a fantasy world where the 'normal' rules could legitimately be suspended. ${ }^{33}$

Someone or some object in its natural environment is not necessarily exotic - it is the outside viewer with different standards who interprets them as exotic. Taking or seeing other peoples and objects out of their natural context turned them into exotic 'curiosities'. For Bernard Smith, the exotic "was a category of accommodation by means of which the European perceived and interpreted the Other according to the limits and constraints of European understanding". ${ }^{34}$ The exotic as an aesthetic category originates in Europe, or the European mind, when perceiving and seeking to understand the foreign; and although it is present in the initial viewer ("the unknown being viewed naturally enough in terms of the known"), more importantly, it is a way of transforming these first-hand records to serve the diverse needs of a European audience. ${ }^{35}$ So the exotic is not 'out there' waiting to be discovered; it is produced by taking objects or people from their 'other' setting and transposing them to a different setting. ${ }^{36}$ Objects from different parts of the world could be combined in one image to enhance its exotic appeal; geographical specificity is not important, what matters is the contrast with home or the familiar. Mason says that remoteness rather than specificity is important; ${ }^{37}$ yet, the 'exotic' could also be quite close to home (for example, Spanish scenes could be seen as exotic in England and France). A French writer of the time commented: "We know that the most refined countries of Europe have customs which would surprise us were we to discover them in America or amongst the negroes". 38

\footnotetext{
32 ibid, p. 5.

33 ibid, p. 13.

${ }^{34}$ Bernard Smith, Imagining the Pacific: in the wake of the Cook voyages, Melbourne: Melbourne University Press at the Miegunyah Press, 1992, p. 10.

35 ibid.

${ }^{36}$ Peter Mason, Infelicities: representations of the exotic, Baltimore \& London: Johns Hopkins University Press, 1998, p. 3.

37 ibid, p. 159.

${ }^{38}$ Quoted in Daniel Roche, [1989] The culture of clothing: dress and fashion in the Ancien Regime, translated by Jean Birrell, Cambridge: Cambridge University Press, 1994, p. 25.
} 
The exotic is a 'lure', but it is also elusive, according to Mason - it draws peoples' interest, but never quite satisfies. ${ }^{39}$ There is still a sense of this in some contemporary travel literature, where some travellers seek areas of the world and peoples that are ever more remote and supposedly 'untouched' by western ideas and lifestyles. The dissatisfaction may come from the apparent need to see the exotic in familiar terms. Bougainville, for example, saw Tahiti in terms of a 'New Cythera' ${ }^{40}$ In some ways the audience expects to see what it wants to see. This may 'tame' the unfamiliar, and perhaps adds a measure of control, but once something is too familiar it no longer fulfils the desire for exotic difference. This sense of appropriating or wanting to control the unfamiliar is incorporated in Roger Célestin's definition of exoticism. He puts forward the idea of two poles or tendencies of exoticism - what he calls exemplification and experimentation. In exemplification the 'other' is only there to illustrate some European viewpoint, while in experimentation the European individual explores the foreign as a way of strengthening individuality - at its extreme it sometimes results in a 'loss of self' or 'merging with the other'. He sees exemplification as particularly prevalent in the eighteenth century: "Exemplification is characterised by the appropriation of the exotic through its representation for the Centre ... to provide a means of ... incorporating, of controlling". ${ }^{41}$ In Denis Diderot's (1713-1784) Supplement to the Voyage of Bougainville (1772) (circulated at the time, but not published until 1796) the exemplification pole has one of its strongest texts: the Tahitians gradually disappear, overshadowed by the (philosophical) point whose illustrations they are meant to be. $^{42}$

The exotic genre was used for criticising one's own society - Diderot's Supplement is an example. Comparison was one of the key methodologies of Enlightenment thinking. In the eighteenth century, European writers were, as Rousseau and Porter argue, "sufficiently self-critical to confront other cultures, admittedly not as equals, but at least as alternative versions of living". ${ }^{43}$ This is the main meaning Tzvetan Todorov gives to exoticism: it is "less a valorization of the other than an act of self-criticism, less the

\footnotetext{
${ }^{39}$ Mason, 1998, pp. 152-3.

${ }^{40}$ Cythera was the Aegean island associated with Venus/Aphrodite in classical mythology, and therefore with love.

${ }^{41}$ Roger Célestin, From cannibals to radicals: figures and limits of exoticism, Minneapolis \& London: University of Minnesota Press, 1996, p. 6.

42 ibid, p. 25.

${ }^{43}$ Rousseau and Porter, p. 14.
} 
description of a reality than the formulation of an ideal". ${ }^{44}$ Like Célestin he sees two poles - the things European authors chose to focus on are usually along an axis that opposes simplicity to complexity, nature to art, origins to progress, savagery to sociality, spontaneity to enlightenment:

Thus, in theory, there are two symmetrical sorts of exoticism, depending on whether the culture or people are considered to be simpler or more complex than ourselves, more natural or more artificial, and so on. In practice, however ... western European authors considered themselves to be bearers of a culture that was more complex and more artificial than any other ... In short, up to fairly recent times exoticism was necessarily accompanied by primitivism. ${ }^{45}$

According to Arthur Lovejoy and George Boas a 'cultural primitivist' is discontented with 'civilisation' or some feature of it, and almost invariably believes that the simpler life is lived by so-called 'savages'. Lovejoy and Boas coined the two terms, soft and hard primitivism, to identify, respectively, those whose lives were thought to be simpler and 'easier' than the European and those whose lives were harder and austere, but bore it courageously. ${ }^{46}$

Some writers have seen during the eighteenth century a paradigm shift in the way in which the native inhabitants of new worlds were understood and described. ${ }^{47}$ Renaissance perceptions of difference were religious rather than racial or national, whereas in the eighteenth century this was replaced by natural history as the basis for seeing others. For example, Montesquieu (1689-1755) and Buffon (1707-1788) emphasised variations in the natural environment, arguing that the supposed European superiority derived from the geographical advantages offered by its climate and soils. ${ }^{48}$ Montesquieu claimed that warm climates create physiological weaknesses, which in turn generate moral and political subservience. ${ }^{49}$ Buffon had argued that the mammals of the Americas were smaller and the

${ }^{44}$ Tzvetan Todorov, On human diversity: nationalism, racism, and exoticism in French thought, translated by Catherine Porter, Cambridge, Mass \& London: Harvard University Press, 1993, p. 264.

45 ibid, p. 266.

${ }^{46}$ Arthur Lovejoy and George Boas, [1935] Primitivism and related ideas in antiquity, New York: Octagon books, reprinted 1965, pp. 7-10.

${ }^{47}$ Rod Edmond, Representing the South Pacific: colonial discourse from Cook to Gauguin, Cambridge: Cambridge University Press, 1997, p. 7.

${ }^{48}$ Denis Cosgrove, Apollo's eye: a cartographic genealogy of the earth in the Western imagination, Baltimore \& London: The Johns Hopkins University Press, 2001, p. 198.

${ }^{49}$ Madeleine Dobie, Foreign bodies: gender, language, and culture in French Orientalism, Stanford: Stanford University Press, 2001, p. 39. 
indigenous people weaker than those of other continents. ${ }^{50}$ This approach tended to limit the capacity of humans to alter their condition. An alternative was proposed by AnneRobert-Jacques Turgot (1727-81) who saw human societies moving toward the perfectibility that European society had most nearly achieved, and found evidence of previous stages in remoter parts of the globe. ${ }^{51}$ While Scottish philosophers emphasised the mode of subsistence as a way of identifying the stages - from hunting, through herding, then agriculture to trading - French philosophes were more likely to rank societies by reference to a vaguer notion of the state of the arts and sciences. ${ }^{52}$

In the eighteenth century, natural history became an important way of knowing and representing the world. Carl von Linné (Linnaeus, 1707-1778) eventually included humans among his classification of animals. By 1758 he had divided homo sapiens (his term) into six varieties, whose main features are summarised below:

a. Wild Man - four-footed, mute, hairy.

b. American - copper-coloured, choleric, erect. Hair black, straight, thick; nostrils wide; face harsh; beard scanty; obstinate, content, free. Paints himself with fine red lines. Regulated by customs.

c. European - fair, sanguine, brawny; hair yellow, brown, flowing; eyes blue; gentle, acute, inventive. Covered with close vestments. Governed by laws.

d. Asiatic - sooty, melancholy, rigid. Hair black; eyes dark; severe, haughty, covetous. Covered with loose garments. Governed by opinions.

e. African - black, phlegmatic, relaxed. Hair black, frizzled; skin silky; nose flat; lips tumid; crafty, indolent, negligent. Anoints himself with grease. Governed by caprice.

f. Monster - dwarfs, giants; as well as 'man-made' monsters such as eunuchs. ${ }^{53}$

Following the end of the Seven Years' War in 1763, voyages to the Pacific were once again on the agenda of the European powers, and in the later eighteenth century Oceanic peoples came to replace the Americas as a testing ground for ideas about the natural. ${ }^{54}$ This began in 1756 when Charles de Brosses (1707-1777) published in Paris a two-volume Histoire des navigations aux terres australes; a history of previous accounts of

${ }^{50}$ Peter Hulme and Ludmilla Jordanova (eds), The Enlightenment and its shadows, London \& New York: Routledge, 1990, introduction, p. 10.

${ }^{51}$ Cosgrove, p. 198.

${ }^{52}$ T. Carlos Jacques, 'From savages and barbarians to primitives: Africa, social typologies, and history in eighteenth-century French philosophy', History and theory, 36(2), May 1997, pp. 203-4.

${ }^{53}$ John Burke, 'The wild man's pedigree: scientific method and racial anthropology' in Edward Dudley and M. Novak (eds), The wild man within: an image in western thought from the Renaissance to Romanticism, Pittsburgh: University of Pittsburgh Press, 1972, pp. 259-280.

${ }^{54}$ Hulme and Jordanova, p. 10. 
voyages to the Pacific. Tom Ryan sees it as "marking a fundamental change in Western thinking about the human inhabitants of the South Seas, a shift from a gaze dominated by the monstrous and fantastic to another more deliberately rational and scientific". ${ }^{55} \mathrm{De}$ Brosses organised the accounts into three regions - Magellanie (South Atlantic); Australasie (everything south of Asia, including New Zealand); and Polynésie (everything in the Pacific Ocean); and he saw fundamental differences between the inhabitants of the latter two regions. The 'austral peoples' supposedly had a philosophy of only doing as much work as was necessary to procure agreeable commodities. And the peoples of Magellanica and New Holland (Australia) illustrate "the most miserable way of life in the world" ${ }^{56}$ Johann Reinhold Forster - naturalist on Cook's second voyage - divided Oceanic peoples into two 'varieties' or 'races'; the first, which he considered more advanced than the second, comprised Tahiti, Marquesas, Tonga (or Friendly Isles) and New Zealand (he also ranked them within the group in that order with Tahiti highest). The second group comprised New Caledonia, Tanna (New Hebrides) and Malikula. ${ }^{57}$ Bernard Smith applied Lovejoy and Boas's notion of 'soft' and 'hard primitivism' to how writers had typically seen Oceanic peoples - 'soft primitivism' applied mainly to the inhabitants of the Society Islands (including Tahiti) and 'hard primitivism' applied to peoples such as the Fuegians, Māori, and Australian Aborigines. ${ }^{58}$

An approach based on natural history could accommodate both negative and relatively positive views, usually depending more on the viewpoint of the observer than on the behaviour of the observed. Todorov wonders whether there is not a natural inclination of travellers to praise what they have seen; "otherwise how could they justify the risks, the exhaustion, the expense?"59 And if one is perfectly satisfied with everything at home, why travel? "We shall not be surprised then to find the image of the noble savage and its obligatory counterpart, the critique of one's own society, amply represented in travel

\footnotetext{
55 Tom Ryan, “Le president des Terres Australes": Charles de Brosses and the French Enlightenment beginnings of Oceanic anthropology', The journal of Pacific history, 37(2), Sept. 2002, p. 158.

56 ibid, p. 175.

57 Johann Reinhold Forster, [1778] 'On the varieties of the human species' in Observations made during a voyage round the world, Nicholas Thomas, Harriet Guest, and Michael Dettelbach (eds), Honolulu: University of Hawaii Press, 1996, pp. 153-171.

${ }^{58}$ Bernard Smith, European vision and the South Pacific 1768-1850, London, Oxford, New York: Oxford University Press, 1960, p. 6.

59 Todorov, p. 270.
} 
narratives". ${ }^{60}$ These kinds of descriptions of 'savage' life are often just the inverse of European; not necessarily saying much about the other, but a lot about the kind of ideal society the European writer would like. Todorov sees three features that most writing of the 'noble savage' genre shares: what he calls an egalitarian principle, a minimalist principle and a naturalist principle. ${ }^{61}$ The egalitarian saw an absence of hierarchy or subordination resulting in freedom. The minimalist sees subsistence production - the 'savages' limit themselves to what they need, resulting in an idle life; and the naturalist sees living in conformity with nature - this could mean in conformity with what is 'reasonable' or sometimes related to spontaneous (instinctual) behaviour. An example is Guillaume Raynal's (1713-1796) Histoire...les deux Indes (1770) where his praise of the 'savage' is used to criticise aspects of the ancien régime. However, he also expressed negative views of 'savages' in the same work - in particular those in France's colony of Guiana. ${ }^{62}$ Pierre de Charlevoix (1682-1761) is another writer who expressed both positive and negative views about the same Canadian Indians, but in different books; Ter Ellingson attributes the differences at least partly to the different audiences Charlevoix intended for his two works - French nobility for one and Jesuits for the other. ${ }^{63}$

Some of the images in the illustrated encyclopaedias in this study are of 'Oriental' peoples and therefore theories about orientalism could be considered. For Edward Said, in his 1978 book Orientalism, Oriental studies by Europeans were a means of dominating, restructuring, and having authority over the Orient. ${ }^{64}$ Said's interest is mainly in 'modern orientalism', which he sees beginning with Napoleon's invasion of Egypt in $1798 .{ }^{65}$ As Madeleine Dobie discusses, in France in the eighteenth century there was an 'obsession' with the Orient, but very little discussion about France's own New World colonies or practices of slavery, at least until the $1770 \mathrm{~s} .{ }^{66}$ Where slavery or colonialism was discussed it was usually in the abstract or 'displaced' onto other countries' colonies or 'Oriental' slavery practices. Therefore, while some (including Said) have seen the French eighteenth-

\footnotetext{
${ }^{60} \mathrm{ibid}$, p. 271. 'Noble savage' is le bon sauvage in Todorov's original French.

61 ibid, pp. 273-275.

${ }^{62}$ William Womack, 'Guillaume Raynal and the eighteenth-century cult of the noble savage', Bulletin of the Rocky Mountain Modern Language Association, 26(3), Autumn 1972, pp. 98-107.

${ }^{63}$ Ter Ellingson, The myth of the noble savage, Berkeley, LA \& London: University of California Press, 2001, pp. 101-102.

${ }^{64}$ Edward Said, Orientalism, New York: Vintage Books, 1978, p. 3.

65 ibid, p. 42.

${ }^{66}$ Dobie, pp. 17-18.
} 
century fascination with the Orient as a 'rehearsal' of its expansion into the Orient at the end of the century, viewed in light of a paucity of debate about France's existing colonies: "eighteenth-century [French] Orientalism seems to be not a properly colonial discourse, but on the contrary the negation or displacement of a discourse on the colonies". ${ }^{67}$

Orientalism is closely tied to assertions of European political power and dominance - whereas some writers on exoticism see that as less overtly political:

It is not the original geographic or cultural contexts which are valued, but the suitability of the objects to assume new meanings in a new context. It is indifferent to ethnographic or geographic precision and tends to serve imaginative rather than concretely political ends. ${ }^{68}$

However, at this period, as Célestin argues, only Western Europe had the power to make their own culture an "ultimate standard of measurement for all other cultures. What is in fact not at all natural but historical acquires the appearance of naturalness through power". ${ }^{69}$ Only the European observer could travel so far (had the means and desire to) and gather information as well as material objects. However, where colonisation becomes the norm, the exotic becomes obsolete. ${ }^{70}$ This relates to the idea I expressed earlier, that the closer and more familiar one gets with the 'exotic' the more it loses its exotic appeal; it ceases to be 'exotic'. As Todorov says, particularly if one wishes to idealise the 'other', "one must not describe it in too much detail". ${ }^{71}$ This provides one reason why exoticism seems more appropriate to analyses of eighteenth-century Oceania and orientalism to the nineteenth, when colonies had become established.

Although orientalism has had a significant influence on subsequent scholarship, it has also been criticised. For example, John MacKenzie notes some of the areas of challenge to Said's views:

His notion of unchallenged western dominance; his identification of a monolithic and predominantly male-originated discourse, which equally subjects the West to 'occidentalism' ... to these we can add a historicism which is essentially ahistorical; an unwillingness to grapple with political economy, with class, and the contrasting economic and social circumstances of different territories; and difficulties in ...

\footnotetext{
${ }^{67}$ ibid, p. 18.

${ }^{68}$ Mason, 1998, p. 3.

${ }^{69}$ Célestin, p. 14.

${ }^{70}$ Rousseau and Porter, p. 14.

${ }^{71}$ Todorov, p. 271.
} 
establishing the precise relationship between scholarly Orientalism and imperial instrumentality. ${ }^{72}$

In art history, orientalism has been applied more to the nineteenth and early twentieth centuries than the eighteenth, although depictions of the Orient (Turkey for example) were popular in the eighteenth century. Perrin Stein, who studied eighteenth-century French images of turquerie, mainly used a framework of exoticism rather than orientalism. ${ }^{73}$ As Stein argues: "fantasies of territorial expansionism could, in eighteenth-century constructions of the exotic 'other', take a backseat to allegorical functions built around gender and class differences closer to home", 74

Exoticism does, however, share with orientalism a link with the erotic: both have a gendered dimension. And Linda Nochlin's notion that the gaze of the western spectator, by virtue of its very absence from Orientalist depictions, is the controlling gaze that brings the Oriental world into being, could also be applied to exoticism. ${ }^{75}$ The eighteenth-century Enlightenment is often seen to have adopted a universalist position - one that affirms the existence of a universal human nature, but all too often it uses the European male as the measure of a 'universal' standard. ${ }^{76}$ This perspective could make women invisible, except for their sexual role. The observers in Oceania for most of the eighteenth century were overwhelmingly male and on Cook's voyages their perception of the position of women in each society was taken to be one of the main markers of the advancement of society as a whole. For example, the writers are usually disapproving of examples of female labour, taking it as evidence of the degeneracy and tyranny of men. ${ }^{77}$ Writers on orientalism have pointed out that the Orient was often perceived as feminine, and this can also sometimes be seen in writing about Oceania, for example, Forster comments on the men of Tahiti that the "outlines of their bodies are... beautifully feminine". ${ }^{78}$

\footnotetext{
72 John MacKenzie, Orientalism: history, theory and the arts, Manchester \& NY: Manchester University Press, 1995, p. 11.

${ }^{73}$ Perrin Stein, 'Exoticism as metaphor: turquerie in eighteenth-century French art', PhD thesis, New York University, 1997.

${ }^{74}$ Perrin Stein, 'Amédée Van Loo's costume turc: the French sultana', The art bulletin, 78(3), Sept. 1996, p. 417.

${ }^{75}$ Linda Nochlin, The politics of vision: essays on nineteenth century art and society, London: Thames and Hudson, 1991, p. 37.

${ }^{76}$ Dobie, p. 59.

${ }^{77}$ Harriet Guest, 'The great distinction: figures of the exotic in the work of William Hodges', Oxford art journal, 12(2), 1989, p. 40.

78 ibid, p. 38.
} 
While Enlightenment scientists might have been concerned to find natural factors, such as climate, to explain the differences between people, in more popular spheres such as pantomime, ballet, and fiction, clothing marked cultural difference. For example, in Montesquieu's fictional Lettres persanes [Persian letters] (1721), when one of the Persian men exchanges his Persian clothing for French clothing, he writes: "I had every reason to complain of my tailor, who in one moment, made me lose the attentions of public esteem, for I immediately fell into a frightful void. I could stay sometimes for a whole hour in a social gathering without being looked at". ${ }^{79}$ In other words, his identity to the French was dependent on his clothing (at least until he spoke). Clothing (the fabric, style, fit, the accessories, as well as the wearer's poise) in the eighteenth century was one of the main markers of social status, occupation, and identity for Europeans, and especially for the French. From mid-century, criticism of spending on women's clothing and appearance increased, often expressed in terms of its artifice and as being contrary to nature. A simpler style of clothing began to appear - for example, Queen Marie-Antoinette appeared in muslin dresses, which were considered by many as inappropriate to her position. In terms of some of the themes of this study, the Orient was seen to be conservative in its customs and clothing; a French observer noting "our villagers are rather Turkish with regard to fashion". ${ }^{80}$ As this implies, the clothes of the poorer and provincial sections of European society changed relatively little; it also shows how readily European observers judged the clothing and appearance of others.

The images of Oceanic peoples in the universal geographies and costume books in this study are predominantly sourced from the art of Captain Cook's three world voyages. The designers and engravers would have relied on published accounts as sources, rather than the original artist's drawings or watercolours. Bernard Smith was one of the first art historians to discuss in detail the differences between original voyage drawings and their published engravings - the engravers adapted the original to suit the techniques of engraving and their European artistic training and preconceptions. ${ }^{81}$ The books in my study are another step removed from the published travel accounts and the extent to which they

\footnotetext{
${ }^{79}$ Baron de Montesquieu, [1721], The Persian letters, edited, translated and introduced by J. Robert Loy, New York: Meridian Books, 1961, p. 87.

${ }^{80}$ Daniel Roche, p. 4.

${ }^{81}$ See Bernard Smith, European vision and the South Pacific, New Haven \& London: Yale University Press, $2^{\text {nd }}$ ed., 1984; and Imagining the Pacific, 1992.
} 
follow their sources will be considered in subsequent chapters. It should be said that neither the original voyage art, nor the engravings in the travel accounts, nor the illustrated encyclopaedias in my study were regarded as 'high art' at the time. History painting was considered the highest genre, and notably Sir Joshua Reynolds (1723-1792) in his eleventh discourse (1782) criticised the kind of landscape that John Webber (1751-1793; the artist on Cook's third voyage) did - an artist should show the 'general effect'; apply "himself to the imagination, not to the curiosity, and works not for the virtuoso or the naturalist, but for the common observer of life and nature". ${ }^{82}$

Studies of the art of Cook's voyages (and its derivatives) will inevitably need to engage with the pioneering work of Bernard Smith in European vision and the South Pacific (1960, 1984) and Imagining the Pacific (1992). Smith made a number of important arguments, such as the opening of the Pacific was one of the factors contributing to the triumph of Romanticism and science in the nineteenth century. While some of his arguments have subsequently been disputed, as Harriet Guest noted in 2007, "My own work is indebted rather to Smith's emphasis on the need to understand European encounters with the people and landscapes of the South Pacific as more or less shaped by the cultural baggage they carried with them..." ${ }^{83}$ While the voyage art has been discussed by art historians such as Bernard Smith and Rudiger Joppien, the subsequent uses of it in more popular forms have not received much attention. When this material has been discussed it has not been looked at in the wider context of the other images in the books or in relation to the text. ${ }^{84}$ Grasset de Saint-Sauveur's images, in particular, are often seen as charmingly exotic and not very accurate, but according to Perrin Stein, the lack of veracity of such exotic images should be seen as a hint that the artist's interests lay elsewhere, rather than as a failing. ${ }^{85}$ In fact, Peter Mason argues that the verisimilitude of exotic images derives from their conformity to certain conventions, rather than their correspondence to objects and practices encountered in the 'field'. These conventions include non-specificity, evocation of

\footnotetext{
${ }^{82}$ Quoted in Bernard Smith, 1984, p. 111.

${ }^{83}$ Harriet Guest, 2007, p. 6.

${ }^{84}$ For example, see Rüdiger Joppien, 'The artistic bequest of captain Cook's voyages - popular imagery in European costume books of the late eighteenth and early nineteenth centuries', in Robin Fisher and Hugh Johnston (eds), Captain Cook and his times, Vancouver \& London: Douglas \& McIntyre/ Croom Helm, 1979; and Martin Terry, 'The voyages of Captain Cook: a Pacific theme in French decorative arts', The French-Australian cultural connection: papers from a symposium held at the University of New South Wales, 16-17 September 1983, School of French, University of NSW and CEEFA, 1984.

${ }^{85}$ Stein, 1997, p. 4.
} 
antiquity, and assuming the practices of lesser known peoples can be 'read' from those who were better documented. ${ }^{86}$ This study looks at the images of Oceanic peoples in relation to the books as a whole, to try to add to our understanding of what this said about Europeans and their views of other peoples at that time.

Some explanations of terminology used in the rest of this study are needed. As a number of authors have pointed out, terms relating to the Pacific are contested, and 'Oceania' is currently favoured as more encompassing. This is the term I will use unless another term is used in quotations. I will refer to the English books in this study as 'universal geographies' as that term often appears in their titles, and is used by Charles Withers, for example, who has studied this genre. ${ }^{87}$ The French books in this study are commonly referred to as 'costume books' (recueils de costumes). Although we now think of 'costume' as specific to clothing and accessories (perhaps in a more theatrical sense) in the eighteenth century it did not only have that meaning. 'Costume' came into French and English from Italian - in the mid-seventeenth century in French and the early eighteenth century in English. In English, at least, it initially had a meaning specific to painting. This use appears, for example, in 1715 in Jonathan Richardson's An essay on the theory of painting:

Every person, and thing must be made to sustain its proper character; and not only the Story, but the Circumstances must be observed, the scene of Action, the Countrey or Place, the Habits, Arms, Manners, Proportions, and the like, must correspond. This is call'd observing the Costûme. ${ }^{88}$

Even later in the century, the Encyclopaedia Britannica (1778-83) limited the meaning of 'costume' to its use in painting. ${ }^{89}$ In French it would appear to have taken on the more modern meaning relating to clothing by the mid-eighteenth century; so in eighteenth century France, using the word 'costume' was ambiguous and could mean both clothing

\footnotetext{
${ }^{86}$ Peter Mason, 'Ethnographic portraiture in the eighteenth century: George Psalmanaazaar's drawings of Formosans', Eighteenth-century life, 23(3), 1999, pp. 58-76.

${ }^{87}$ Charles Withers, 'Encyclopaedism, modernism and the classification of geographical knowledge', Transactions of the Institute of British Geographers, (new series) 21(1), 1996, pp. 275-298.

${ }^{88}$ Jonathan Richardson, An essay on the theory of painting, London, 1715, Eighteenth-century collections online, VUW Library, accessed 16 August 2008.

${ }^{89}$ Encyclopaedia Britannica, Edinburgh, 2nd ed., 1778-83, Eighteenth-century collections online, VUW Library, accessed 16 August 2008.
} 
and custom. ${ }^{90}$ Except when referring to the genre of 'costume books', I will prefer the term 'clothing' as that was more commonly used in the eighteenth century. ${ }^{91}$ The next chapter will discuss the costume book genre more fully, but I note here that the earliest costume books used the word 'habits' in their titles (again, an ambiguous word in English today, meaning both clothing and customs). When referring to both the universal geographies and costume books I have used a generic term of 'illustrated encyclopaedias'.

The next chapters will consider the illustrated encyclopaedias, using the framework of curiosity, exoticism, and the iconography of clothing, as well as considering relevant contemporary developments. Chapter two presents an overview of the genres of the books considered in this study. In many respects, the books continued to follow their genre traditions and fitted the 'new discoveries' of Oceania into these existing traditions. Also, to meet publishing deadlines, it was quicker to recycle existing images than design new ones. Chapter three considers the frontispieces to the books, most of which are allegories of the continents, and what this can tell us about the books and their potential readers. The frontispieces embody moral value judgements and reveal European views of political, social and economic relations between Europe and other peoples and countries at that time. They followed iconographic traditions set down much earlier and generally failed to incorporate recent events that challenged these traditions. Chapter four looks at how the images of Oceanic peoples in the costume books were developed (or as I argue 'invented') from the source material. The French costume books were following a tradition that emphasised clothing and adornments and their sources are just as likely to have included other costume books as the voyage accounts. In inventing images designed to please the eye, the sources chosen reveal the prejudices and expectations of European readers. Chapter five considers the Oceanic images within the context of the books. By seeing Oceanic peoples as part of America it was easy to fit them into existing prejudices about 'savages' and into existing pictorial conventions for depicting 'savages'. I argue the books reveal a fairly superficial interest, at a popular level, in other peoples: one that is mainly interested in contrasting 'civilised' Europe with less civilised or 'savage' others. Chapter six concludes the study, which will highlight more popular views rather than those of

\footnotetext{
${ }^{90}$ Le Grand Robert de la Langue Française, 2001; gives as 'old' use for 'costume': 'Ensemble des caractéristiques d'une époque, des moeurs, des coutumes [customs] d'un peuple'. For 'modern' use, which it dates to 1747: 'Manière de se vêtir [dress] particulière à un pays, une époque, une condition.'

${ }^{91}$ Roche, p. 4.
} 
philosophers, or the voyagers' accounts, which understandably have been given more academic attention. These books are overlooked today because they are derivative and their images are not necessarily ethnographically accurate; but they were popular in their time. They represent a conservative Eurocentric viewpoint and their inclusion of new material from Oceanic voyages did not challenge these views. Images and texts such as these likely reinforced European views of their own superiority and made it easy to justify missionary activity and colonisation in various parts of the world, including Oceania. 


\section{Chapter 2 - The genres: encyclopaedias, cosmographies, and costume books}

The considerable number of new discoveries in Geography ... has opened to us such a NEW WORLD, that it is now become a science more generally studied than any other subject whatever ...92

Reference books of all kinds became popular during the seventeenth century. In the absence of universal education, books (for those who could read) were an important means of self-improvement, offering the potential to better one's social and perhaps economic status. Information that was 'useful' was emphasised, although all the books in this study claimed to provide entertainment as well as information. This chapter considers the genres that the illustrated books in this study fit within. I will briefly trace the development of encyclopaedias, travel accounts and cosmographies, and costume books. The chapter also considers some relevant matters of eighteenth-century book production, what views a reader might expect to find expressed in these books, and some particular aspects of ethnographic illustration, to place the books in their contexts. All these genres began earlier than the eighteenth century, but the second half of the eighteenth century saw a dramatic growth in publishing generally and in illustrated books in particular. Yet they continued in many respects to follow their genre traditions and fitted the 'new discoveries' of Oceania into these existing traditions.

Encyclopaedias - originally meaning circle of learning or 'rounded' knowledge have an ancient lineage, but in their modern form arose towards the end of the seventeenth century. According to Richard Yeo they are:

closely linked with the emergence of modernity, with assumptions about the public character of information and the desirability of free intellectual and political exchange that became distinctive features of the European Enlightenment. ${ }^{93}$

The purpose of the pre-seventeenth-century works was to store and preserve traditional knowledge. One of the main changes of the later seventeenth and eighteenth-century encyclopaedias was to present new knowledge and remove errors of previous editions to

\footnotetext{
${ }^{92}$ Thomas Bankes, New, royal and authentic system of universal geography ... Europe, Asia, Africa and America... London: C. Cooke, Paternoster Row, 1790, Address to the Reader, unpaginated.

${ }^{93}$ Richard Yeo, Encyclopaedic visions: scientific dictionaries and Enlightenment culture, Cambridge: Cambridge University Press, 2001, p. xii.
} 
encourage open-ended enquiry. ${ }^{94}$ Another important change from the earlier encyclopaedias was their arrangement - from presenting subjects thematically (or 'systematically') to an alphabetical ordering. Encyclopaedias aimed to present a comprehensive amount of knowledge in an ordered way. The word 'universal' often appears in titles - while referring to the wide scope of the books, it also suggested there would be a 'universal' interest in the work - or at least a hope that educated men and women in Europe would buy the work. ${ }^{95}$ It also implies that European knowledge and a worldview is the norm or unquestionably the 'universal' one - a theme I will return to later in the chapter.

Yeo traces the beginnings of modern encyclopaedias to the dictionaries of arts and sciences beginning around 1690 with Antoine Furetière's Dictionnaire universel, 1690 (The Hague). ${ }^{96}$ However, these tended to exclude history, biography and sometimes geography and a separate genre of 'historical dictionaries' covered these topics - Louis Moréri's Grand dictionnaire historique, ou mélange curieux de l'histoire sacrée et profane (1674) is usually regarded as the first of this kind to be arranged alphabetically. ${ }^{97}$ As can be seen from the short title, curiosity was an important ingredient in this 'curious mix' of sacred and secular history. Among many other topics listed in his very long title, Moréri's book included geography and "les moeurs, les coutumes, le gouvernement et la religion des Peuples". ${ }^{98}$ In some later eighteenth-century encyclopaedias the two genres (historical, and arts and sciences) come together. Neither Moréri's nor Furetière's dictionaries contained maps or illustrations, although early English editions of these works did contain a few.

Illustrations formed an integral part of Ephraim Chambers's Cyclopaedia published in London in $1728 .{ }^{99}$ These illustrations combined a number of objects in one plate. An Italian encyclopaedia (Venice 1746-1751) had many 'finely executed' plates at the end of each volume, and was particularly strong on representing the customs of various peoples of

\footnotetext{
94 Yeo, p. 12.

95 ibid, p. 54.

${ }^{96}$ ibid, p. 12. There were single subject and language dictionaries arranged alphabetically before this.

97 ibid, p. 17.

${ }^{98}$ Arnold Miller, 'Louis Moréri’s Grand dictionnaire historique', in Frank Kafker (ed), 'Notable encyclopedias of the seventeenth and eighteenth centuries: nine predecessors of the Encyclopédie', Studies in Voltaire and the eighteenth century, 194, 1981, p. 14. ("the mores, customs, government and religion of the peoples'.)

${ }^{99}$ Lael Ely Bradshaw, 'Ephraim Chambers' Cyclopaedia' in Frank Kafker (ed), 'Notable encyclopedias of the seventeenth and eighteenth centuries: nine predecessors of the Encyclopédie', Studies in Voltaire and the eighteenth century, 194, 1981, p. 127.
} 
the world. ${ }^{100}$ Perhaps the most well-known of eighteenth-century encyclopaedias was the French Encyclopédie, ou dictionnaire raisonné des sciences, des arts, et des métiers, par une société de gens de letters, edited by Denis Diderot and Jean le Rond d'Alembert (17171783), and published from 1751 to 1772 in 17 volumes of text and 11 volumes of plates. This began as a translation of Chambers's Cyclopaedia. Alphabetical arrangement allowed new material to be slotted in more easily and could mean such a book was more accessible to a wider reading public than the earlier ones. However, Yeo cautions that alphabetical arrangement still required some prior knowledge of major subject categories. ${ }^{101}$ Both Chambers's Cyclopaedia and the Encyclopédie included diagrams of the ordering of knowledge - how various subjects were related to each other. The Encyclopédie broke with tradition by downgrading the role of theological knowledge and also dispensed with the idea of a proper order of study based on moral considerations. ${ }^{102}$

Travel accounts also have a long history, and include medieval pilgrimages and guide books written for pilgrims. However, the genre increased in popularity with the European 'discovery' of the Americas and increasing commercial voyages to both Asia and the Americas. Travel accounts were classified with 'historia' - the description of empirical facts of various kinds, and not 'scientia' - systematically deduced knowledge, which was considered more reliable. ${ }^{103}$ There was something paradoxical about them - as readers wanted to read about unusual and extraordinary things, authors tried various ways of authenticating their works - mainly this was through a deliberately plain style and also by claiming 'eyewitness' status to the exotic marvels reported. The line between fact and fiction was not always clear, but it is unlikely to have mattered to many readers, unless they actually relied on the book as a guide for their own travels. Even a guidebook on France written by a Frenchman in 1771 was found by a traveller in 1790 to have many errors, but

\footnotetext{
${ }^{100}$ Silvano Garofalo, 'Gianfrancesco Pivati's nuovo dizionario' in Frank Kafker (ed), 'Notable encyclopedias of the seventeenth and eighteenth centuries: nine predecessors of the Encyclopédie', Studies in Voltaire and the eighteenth century, 194, 1981, pp. 197-219.

${ }^{101}$ Yeo, pp. 26-27.

102 ibid, p. 28. See also Robert Darnton, 'Philosophers trim the tree of knowledge: the epistemological strategy of the Encyclopédie' in The great cat massacre and other episodes in French cultural history, London: Penguin, 1984, pp. 188-208.

${ }^{103}$ Justin Stagl, A history of curiosity: the theory of travel 1550-1800, Chur, Switzerland: Harwood Academic Publishers, 1995, p. 50.
} 
as Graham Robb notes, "Since geographical information was scarce, most writers took their facts from earlier books, which had been plagiarized from even earlier works", 104

Collections of travel reports appeared in the sixteenth century; for example, Richard Hakluyt's Principall navigations, voiages, etc. of the English nation (1589) was compiled for both commercial and nationalistic reasons. The Flemish engraver and publisher, Theodor de Bry published a number of voyage-related works from 1590 on. The 'Grand Voyages' were collections of voyages to the 'West Indies' or the Americas and eventually comprised 13 volumes (published 1590-1634). The first two volumes were based on Hakluyt's work. De Bry's 'Small Voyages' contained collections of travel reports to the 'East Indies' or parts of Asia. ${ }^{105}$ De Bry's American images in A briefe and true report of the new found land of Virginia (1590) were based on John White's drawings (an early settler in Roanoke, Virginia). This book was clearly aimed at encouraging colonial settlement. ${ }^{106}$ In speaking of de Bry's engravings in this book, Michael Gaudio makes a comment that could also apply to some of the books in my study, "De Bry's lines are serviceable, not spectacular. He primarily copied for a more general audience the work of unknown artists" - compared with an engraver such as Hendrik Goltzius's "virtuosic line", who copied the work of prominent artists for print collectors. ${ }^{107}$ However, de Bry’s images were to be widely used as sources for images of American people during the next two centuries. Another example of a long-lived illustration is Animals of Maragnan, coast of Brazil (fig. 3), which shows two animals that appear to have human faces. This was probably originally meant to be a three-toed sloth, which was described in Jean de Lery's Histoire d'un voyage fait en la terre du Brésil (History of a voyage made in Brazil) of 1580 as having a face "rather like a monkey's, approaching the human". ${ }^{108}$ It continued to appear in the seventeenth century and as figure 3 shows, still appears in the late eighteenth century. The same image appears in both Millar's universal geography of 1782 and Moore's

\footnotetext{
${ }^{104}$ Graham Robb, The discovery of France, London: Picador, 2007, p. 282.

105 Bernadette Bucher, Icon and conquest: a structural analysis of the illustrations of de Bry's great voyages, translated by Basia Miller Gulati, Chicago: Chicago University Press, 1981.

${ }^{106}$ Michael Gaudio, Engraving the savage: the new world and techniques of civilization, Minneapolis: University of Minnesota, 2008, p. 1.

107 ibid, p. 49.

108 Jean de Lery, History of a voyage to the land of Brazil..., translated by Janet Whatley, University of California Press, VUW Library, ACLS Humanities e-book, p. 85. Illustrated in Olive Dickason, The myth of the savage and the beginnings of French colonialism in the Americas, Edmonton: University of Alberta Press, 1984, p. 31.
} 
collection of travels of 1790 (both had the same publisher and probably used the same plate with only the book title changed). It was included as one of three illustrations in Moore's 30-page account of Bougainville's voyage. ${ }^{109}$

Books written for travellers also appeared in the early modern period. These told travellers what they should look for, but over time became more explicit in telling travellers the type of information they should find out and how they should record their information. Increasing commercial rivalry between European states in Asia, the Americas and later Oceania was one stimulus for wanting more reliable and orderly accounts. Four main topics were suggested for describing countries: their name and position, climate and natural products, the character and customs of their people, and their form of government. ${ }^{110}$ Travel literature (at least by those authors with scientific credentials or pretensions) became more concerned with describing, classifying and mapping the world; and as Michael Bravo comments: "learned travel, once restricted to those aristocrats who could afford the Grand Tour, could be undertaken much more widely". ${ }^{111}$ In the later eighteenth century, new areas for European travel, such as Oceania or inland India, and new types of travel, such as for 'botanising' or climbing mountains to take measurements, helped satisfy general readers' demands for curiosity, novelty and exotic locations, as well as learned demands for more scientific precision.

Justin Stagl identifies two other types of book which used travel accounts as their main sources - what he calls 'cosmographies' and 'statistical' works. Cosmographies described continents, countries and cities covering the whole known earth, but actually centred on Europe. 'Statistical' works described the world according to 'polities' kingdoms and republics (the name originally designated the knowledge considered necessary for a statesman). ${ }^{112}$ English examples from the seventeenth century include George Abbot's A briefe description of the whole world, $2^{\text {nd }}$ ed, 1600; Peter Heylyn's Cosmographie, in four bookes, $2^{\text {nd }}$ ed, 1657; and Richard Blome's A geographical description of the four parts of the world (1670) and Cosmography and geography in two

\footnotetext{
${ }^{109}$ See bibliography, primary sources, for references to Millar and Moore.

${ }^{110}$ Joan-Pau Rubiés, 'Instructions for travellers: teaching the eye to see' History and Anthropology, 9(2-3), p. 150.

${ }^{111}$ Michael Bravo, 'Precision and curiosity in scientific travel: James Rennell and the orientalist geography of the new imperial age (1760-1830)' in Voyages and visions: towards a cultural history of travel, Jas Elsner and Joan-Pau Rubiés (eds), London: Reaktion Books, 1999, p. 167.

${ }^{112}$ Stagl, p. 56. Just as the later 'gazetteers' gave information designed to be useful to newsmen.
} 
parts (1683). The later eighteenth-century English universal geographies in my study are descendants of books such as these and are usually arranged by continent. While the seventeenth-century ones included the 'new world' of America, the eighteenth-century universal geographies included the 'newer' world of Oceania. The authors of the universal geographies mainly relied on historical and travel accounts for their sources, rather than scientists or cartographers and they wrote for a general public interested in new learning and world-wide commerce. ${ }^{113}$

Travel books were very popular in the late eighteenth century. The library borrowing records survive from Bristol library between 1773 and 1784 showing that John Hawkesworth's compilation (1773) of English voyages of the mid-eighteenth century, including Cook's first voyage, was the most popular item. ${ }^{114}$ The category of 'history, antiquities, and geography' (most of the latter being travel books) was far ahead of any other borrowing category in this period. Other popular travel books included two French works, in English - Louis de Bougainville's Voyage around the world (1772) and Abbé Raynal's History of the settlements and trade of the Europeans in the East and West Indies (1774). The travel genre was also used for other purposes - for example Jonathan Swift's Gulliver's travels (1735) and, as Michael Bravo has stated, Denis Diderot's 'Supplement to Bougainville's voyage' (1772) “used the discourse of travel with its various appeals to curiosity, novelty, utility and natural law to invite their readers to question political authority". ${ }^{115}$ Of course, it is not surprising that allegory and satire were used for criticising forms of government in an era when censorship applied or accusations of libel or treason might be made.

The popularity of travel accounts, and especially of Captain Cook's voyages, is also shown by the production of an early scenic wallpaper, Les sauvages de la mer Pacifique, by the firm of Joseph Dufour and Co., in Mâcon, France in 1804-05. Scenic wallpapers were a late eighteenth-century French development and encompassed a whole room with a continuous view - usually of a peopled landscape. Designed by Jean-Gabriel Charvet,

\footnotetext{
113 Alan Downes, 'The bibliographic dinosaurs of Georgian geography (1714-1830)', The geographical journal, 137(3), Sept. 1971, p. 383.

${ }^{114}$ Hunt, p. 336. Admittedly, Bristol was a port town and its readers may have been more interested in voyages than inland towns.

115 Bravo, p. 163.
} 
hundreds of copies of Les sauvages were produced, accompanied by a 48-page prospectus. ${ }^{116}$ In the prospectus, Dufour stated:

We hoped that viewers would be pleased to see assembled in a convenient and vivid manner this multitude of peoples who are separated from us by vast oceans, arranged in such a way that, without leaving his apartment, a studious man reading the history of the voyages or the specific accounts of the explorers used in these decorations, might think himself ... in the presence of the depicted people. ${ }^{117}$

The wallpaper was therefore seen as a teaching tool in conjunction with books - a vast encyclopaedia on the walls of a salon or dining room. But of course it was also designed to "please the eye" as well as "excite the imagination without taxing it". 118

Costume books first appeared in the sixteenth century, with more than 200 being produced in Europe between 1520 and 1610. ${ }^{119}$ In 1562, a French one included costumes ('habits') from Europe, Asia and Africa in 121 small woodcuts. ${ }^{120}$ A more famous one by Cesare Vecellio, Venice 1598 ( $2^{\text {nd }}$ ed.), added America to the other three continents. Like most of his predecessors, Vecellio emphasised the costumes of his own region (Venice) and arranged his book in a geographical sequence radiating out from Italy ${ }^{121}$ (85\% of his woodcut illustrations were of European costumes). Vecellio's source for some of his American images was Theodor de Bry's engravings, after John White's drawings. The number of costume books increased greatly in the second half of the eighteenth century for example, two-thirds of all the books on clothes published in French from the sixteenth to eighteenth centuries appeared in this latter period. ${ }^{122}$ While Grasset de Saint-Sauveur's books in my study can be considered within the costume book tradition (as they illustrate people in 'typical' costume) his texts provide broader information about peoples and their countries and therefore share some similarities with cosmographies. They are arranged geographically, by continent.

\footnotetext{
${ }^{116}$ Art Gallery of NSW/ National Gallery of Australia, Les sauvages de la mer Pacifique, Sydney/Canberra: Art Gallery of NSW/ National Gallery of Australia, 2000, p. 7.

117 ibid, p. 33. (Translation of the prospectus)

118 ibid.

${ }^{119}$ Cited in Daniel Roche, p. 11.

${ }^{120}$ A. Hyatt Mayor, 'Renaissance costume books', Bulletin of the Metropolitan Museum of Art, 37(6), June 1942, pp. $158-159$.

${ }^{121}$ Cesare Vecellio, Vecellio's Renaissance costume book [1598, $2^{\text {nd }}$ ed.], New York: Dover Publications, 1977, publisher's note, unpaginated. Vecellio was a cousin of the painter Titian, to whom the illustrations were sometimes later attributed.

${ }^{122}$ Roche, p. 12.
} 
The appearance of costume books is partly related to increasing travel in the sixteenth century (made easier by growing wealth flowing in from South American colonies) and curiosity in seeing what other people wore. They would also have been useful for artists and designers of pageants (as discussed in chapter 1, the meaning of 'costume' in English was specific to painting until the eighteenth century). They were a popular genre on the European continent, but not so in England. A search on the British Library's English Short Title Catalogue (ESTC) revealed very few, and most of those were of English 'historical and modern' costumes. ${ }^{123}$ They may not have been popular as a separate genre because it is likely the cosmographies included some illustrations of clothing - for example a book by John Bulwer (1658) is titled: A view of the people of the whole world, or a short survey of their policies, dispositions, naturall deportments, complexions, ancient and moderne customes, manners, habits, and fashions... The universal geographies in my study include illustrations of people in 'typical' clothing. I found only one eighteenth-century English book comparable to the continental costume books - published by Thomas Jefferys from 1757 to 1772 (author unknown) in four volumes, the text is in English and French on alternate pages, perhaps revealing that this is a continental genre, and expecting to find a continental readership. Volume four (published in 1772) contains images of American peoples, but none of Oceanic peoples. ${ }^{124}$ The images of a 'nobleman of Virginia' and 'woman of Virginia' are sourced from the Briefe and true report of the new found land of Virginia (1590) engraved by de Bry; showing just how long de Bry's images continued to be used.

Book publishing and reading levels increased in the second half of the eighteenth century. ${ }^{125}$ The number of books on geography published in France increased from 456 in the sixteenth century, 1,566 in the seventeenth century to 3,540 in the eighteenth century. Over half (53\%) of the eighteenth century ones were on Europe, with $13 \%$ each on America

${ }^{123}$ The ESTC contains material printed before 1801 in Britain, America, Canada, or territories governed by Britain in all languages, and items printed elsewhere wholly or partly in English. http://estc.bl.uk, searched on 4 September 2008.

${ }^{124}$ A collection of the dresses of different nations, antient and modern. Particularly old English dresses ..., 4 vols, published by Thomas Jefferys, 1757-1772, Eighteenth-century collections online, VUW Library, accessed 4 September 2008.

${ }^{125}$ Evidence for Paris, at least, is found in Roche, p. 12; see also Antony Griffiths, Prints for books: book illustration in France, 1760-1800, Panizzi lectures 2003, The British Library, 2004; and David Garrioch 'Reading in eighteenth-century Paris' in The culture of the book: essays from two hemispheres in honour of Wallace Kirsop, Melbourne: Bibliographical Society of Australia and New Zealand, 1999, pp. 288-299. 
and Asia, $6 \%$ on Africa and $2 \%$ on Oceania (and 12\% were 'general'). ${ }^{126}$ How did eighteenth-century booksellers reach their intended audience? Selling books by subscription and in serial form were two common methods for spreading the costs of book production. An advertisement or prospectus for the book was published and subscribers paid for part of the cost prior to production, which only went ahead if enough subscriptions were received (if not, subscribers got their money back). The list of subscribers was commonly included near the front of the book - it was usually alphabetical, but as Yeo says "arranged in such a way that ensured the most prestigious names were at the top of each letter". ${ }^{127}$ Yeo notes that 200 subscribers were considered the minimum in the eighteenth century (at least in England) before a work would proceed. Chambers's Cyclopaedia had 375 for its first edition, but sold far more copies, and subsequent editions did not need subscribers as they were sure of their sales. ${ }^{128}$

Serialisation was also common, with the parts sold in plain paper covers - this was more feasible then than it would be now as purchasers often had books re-bound to match other books in their libraries. Often, instructions for the binder were included listing the proper order, although mistakes were still made; for example, volume five of SaintSauveur's 1796 encyclopaedia in the Alexander Turnbull library has the Mediterranean island of Tinne bound where the Oceanic island of Tanna should be. Unusually, the copy of Saint-Sauveur's 1806 encyclopaedia in the Alexander Turnbull library has some original part covers bound in the back of volume two, as well as two receipts for payment (one showing Saint-Sauveur's signature; fig. 4). On the original covers is listed the price for each part - 3 livres in Paris; 3 livres 10 sous elsewhere. The six maps, which came separately, could be purchased uncoloured for 9 livres, or coloured for 12 livres. SaintSauveur's 1795 encyclopaedia in the Mitchell Library, Sydney, cost 6 livres per part for subscribers in Paris, 7 livres for subscribers elsewhere, and 9 livres for non-subscribers. Interestingly, the order of the volumes was left to the discretion of the binder or purchaser.

In France, the guild system was particularly strong until the Revolution, and although engravers were not part of a guild, most of them worked as suppliers to others, usually publishers or booksellers who would buy the plate. Booksellers held the legal

\footnotetext{
${ }^{126}$ William Cohen, The French encounter with Africans: white response to blacks, 1530-1880, Bloomington \& London: Indiana University Press, 1980, p. 7.

${ }^{127}$ Yeo, p. 47.

${ }^{128}$ ibid, pp. $49-50$.
} 
monopoly for letterpress printing, so any engraver who wanted to link prints with text had to work with booksellers or try to find ways around this. The guild of booksellers encompassed printing, publishing, bookselling and type founding. There were also separate guilds for copper-plate printers, and print colourists. ${ }^{129}$ Prints and text had to be passed by a censor. With all this regulation, it was not surprising, as Antony Griffiths mentions, that book piracy and smuggling in foreign books were rife in France. ${ }^{130}$ Although most of this regulation disappeared with the Revolution, books remained prestigious items, very fashionable and were regarded as a sound investment. In the 1790s books began to be signed and numbered - a century before prints were. ${ }^{131}$

Most of these illustrated encyclopaedias claimed to be both educational and entertaining. ${ }^{132}$ The concept of 'utility' had both moral and practical connotations. Withers notes that some philosophers considered "utility as a moral tenet embracing both the fact, character or quality of being useful or serviceable and the use of such qualities to advance the human condition." 133 But these books were also appealing to a self-interested, practical utility - for example, Thomas Bankes's Address to the reader specifically mentions how his universal geography might be useful to various occupations, and ends with a catch-all category of "the curious enquirer, to gratify his desire for universal knowledge". ${ }^{134}$ So what kinds of information and views could one expect to find expressed in an eighteenth-century geography, travel or costume book? Roche notes that many of the comments in costume books resemble "the stereotyped descriptions of customs and costumes which can be read in travellers' tales. They created an impression and established a difference, but they also revealed what was expected."135 As noted in chapter one, Linnaeus's six varieties of homo sapiens reveal Eurocentric views of others (1758), so it should not be surprising that similar views occur in most of the travel (and similar) literature of the eighteenth century. As Hunt notes:

\footnotetext{
129 Griffiths, pp. 57-60.

130 ibid, p. 63.

131 ibid, p. 143.

132 These notions have a long history, as demonstrated by the Latin phrase utile dulci used by Horace: Omne tulit punctum qui miscuit utile dulci lectorem delectando pariterque monendo. (He wins every hand who mingles profit with pleasure, by delighting and instructing the reader at the same time.) Horace, Ars Poetica, line 343, c. 18 BC. http://en.wikiquote.org/wiki/Horace, accessed 24 June 2009.

133 Withers, p. 276.

${ }^{134}$ Bankes, 1790, 'Address to the reader', unpaginated.

${ }^{135}$ Roche, p. 13.
} 
In travel narratives racist and xenophobic 'truths' work to confirm group values and knit individuals to their preferred community. They titillate authors and readers alike with people and customs just different enough to pleasurably decenter the 'normal'. 136

A class bias is also revealed by the terms that often occurred in English accounts 'thievish', 'slavish' and 'naked'. Thievish could apply to non-English people, servants and the poor. Slavish could include actual slaves, but also some other Europeans, among others. Naked, as a term, was already identified with the English poor before it came to be used for many others; as Hunt says: "one of the major ways the middling classes measured their difference from people they deemed to be their inferiors, whether foreigners or not, was by their clothes, or lack of them". ${ }^{137}$

Published travel accounts provided sources for both text and images in most of the universal geographies and costume books. For the artists on voyages to Oceania, Bernard Smith identifies two conventions that they were able to draw on when deciding how to depict foreign peoples: what he calls the allegorical convention and the ethnographic convention. ${ }^{138}$ The allegorical convention presented places as persons - often a woman as a city, country or continent, for example. This will be more fully discussed in the next chapter which looks at the frontispieces to the illustrated encyclopaedias, most of which contain allegories of continents. The ethnographic convention, according to Smith, defines by means of costume and adornment, and is present in western art from Hellenistic times onwards, whenever a foreigner needed to be portrayed. ${ }^{139}$ On Cook's first voyage, Joseph Banks established a close relationship between text and illustration - he expected his artists to portray peoples in a manner similar to natural history specimens and accompanied by detailed verbal descriptions. Yet, at times, Sydney Parkinson moved beyond the convention and made detailed studies of facial expression and gesture. ${ }^{140}$ However, Mason believes Smith's notion of ethnographic convention (i.e. defining by costume and adornment) is too narrow, as the earliest depictions of Amerindians could include more or less accurate depictions of their clothing and artefacts, but combine them with fanciful depictions of the people wearing them (showing them roasting and eating human body parts was common).

\footnotetext{
${ }^{136}$ Hunt, p. 340.

137 ibid, pp. 342-344.

${ }^{138}$ Smith, 1992, p. 77.

139 ibid. p. 80.

140 ibid. pp. 81 and 85 .
} 
The authenticity of some of the objects is then unjustifiably assumed to extend to the whole image. $^{141}$

Mason believes an 'exotic' image can be made more or less exotic by how it is presented: less exotic by adding, for example, familiar objects ('familiar' to a European audience) such as classical Greek or Roman architecture or artefacts; and made more exotic, for example, putting a real object with a fantastical one. ${ }^{142}$ For example, Theodor de Bry's frontispiece to the 1590 Virginia report has Amerindians inserted into classical architecture - with the goal of bringing the 'unstructured savage' into a civilised social order. ${ }^{143}$ Smith also discusses the role of background or landscape in ethnographic images: "Landscape settings became an important element in the ennobling of savages. Portraits of natives devoid of such settings tend, on the whole, to be more truthful". ${ }^{144}$ The English and French books in my study treat landscape settings differently and I will consider these images in relation to Smith's comment in chapter 5. Nicholas Thomas discusses the way 'curiosities' collected on Cook's voyages were depicted without any background or context. The immediate model for this derived from the conventions of natural history illustration, but as Thomas notes:

In fact, artefacts were not specimens in any meaningful sense: they were not the objects of any theoretical discourse or systematic inquiry; there was nothing akin to Linnaean classification that could be applied to ethnographic objects; they played no significant part in the ethnological project of discriminating and assessing the advancement of the various peoples encountered. ${ }^{145}$

This mode of presentation, Thomas argues, was a way of giving more scientific status to the collection of these objects, and an attempt to legitimise the status of the collector. ${ }^{146}$

The English universal geographies in my study fit within the cosmography tradition, while Saint-Sauveur's books are within the costume book tradition, but with some features (his texts) of cosmographies. All are organised geographically, usually by continent, but some of the English ones present recent voyages separately. They are encyclopaedic in their geographical coverage, but are not encyclopaedias in the sense that they do not include

\footnotetext{
${ }^{141}$ Mason, 1998, p. 46.

${ }^{142}$ ibid, pp. 96-7.

143 Gaudio, p. 11.

${ }^{144}$ Smith, 1984, p. 40.

145 Thomas, 1994, p. 130.

146 ibid, p. 134.
} 
extensive information on all branches of knowledge arranged alphabetically. ${ }^{147}$ The English and French images share some common features - they are prints made for reproduction in books, and as with any illustrated book it is expected there will be a relationship between the text and image; but there are a few major differences between the English and French books. Saint-Sauveur appears to have been both author and designer of at least some of the images, whereas the English books have different authors and artists (the designers and engravers are also usually different people). Bankes's Address to the Reader notes, in relation to the engravings, that the publisher "has undertaken the sole management of that department". Perhaps as a consequence, the English books have more text and fewer illustrations than the French ones, and more often than in Saint-Sauveur's books, the illustrations do not relate to the text in which they are placed. The French prints are handcoloured etching and aquatints, whereas the English engravings are not coloured.

In the late eighteenth century, travel accounts and related books were a very popular genre. They met a curiosity and demand for information about exotic locations and peoples. European readers could see images of, and read about, people with different customs and clothing than themselves. Authors emphasised the usefulness as well as entertainment value of their books. But, while the travel genre was used by Swift and Diderot, for example, to question their own societies, it is likely that most readers of the books in my study would have finished them feeling that their European-civilised ways were affirmed as superior. The role of imagery in this process will now be examined in detail, beginning with the frontispieces as these gave some idea of what to expect in the rest of the book.

${ }^{147}$ The modern definition of encyclopaedia is: "A literary work containing extensive information on all branches of knowledge, usually arranged in alphabetical order", Oxford English Dictionary online, VUW Library, accessed 27 January 2010. 


\section{Chapter 3 -Reading the frontispieces - the four parts of the world}

Europe by Commerce, Arts and Arms obtains

the Gold of AFRIC, and her sons enchains

She rules luxurious ASIA'S fertile shores

Wears her bright Gems, and gains her richest Stores;

While from AMERICA thro' seas she brings

The Wealth of Mines, and various useful things. ${ }^{148}$

Frontispieces, often facing the title page of the book, were common throughout the period I am examining. They offered a visual introduction to, or a summary of, the key ideas in the book; or sometimes they presented a portrait of the author. They could condense ideas that may otherwise have taken a number of pages to explain. They captured the reader's attention and also hopefully created anticipation for the rest of the book. Personifications or allegories were commonly used for this purpose, which could be ambiguous if the reader was not aware of their symbolism. Readers of the time were more used to these images than we are today, nevertheless all the frontispieces in the books in this study include some text, to help explain their meaning (in the case of Saint-Sauveur's books this is only one word - the name of the continent depicted). In travel, geography or costume books it was common to depict personifications of the continents. As I will argue in this chapter, the frontispieces embody moral value judgements and reveal European views of political, social and economic relations between Europe and other peoples and countries at that time. They were conservative - following a tradition set down much earlier - and generally failed to acknowledge recent events that challenged these prevailing views.

A personification is a person representing something else, for example, a virtue, a city, or continent. According to Harvey Shapiro it is only the relationship of two or more personifications that can create allegorical meaning, not the personification per se. ${ }^{149}$ In Greek art, with very rare exceptions, the gender of the personification accords with the gender of the noun. ${ }^{150}$ Many personifications are represented by women, even though women were often thought not to possess the quality depicted (e.g. strength, fortitude, justice). But these figures are not from real life. It is usually through their clothing and

\footnotetext{
${ }^{148}$ Charles Middleton, A new and complete system of geography, London, 1777, frontispiece.

${ }^{149}$ Harvey A. Shapiro, Personifications in Greek art, Zurich: Akanthus, 1993, p. 17.

${ }^{150}$ ibid, p. 27.
} 
attributes (objects accompanying them) that they are shown to 'stand in' for something else. They have a long history and were commonly used in history painting, tapestries and wall decorations, sculpture and in illustrated books.

In the mid-eighteenth century allegorical representation came under criticism mainly for its multitude of figures, which could cause difficulties in interpretation. This led some writers to see how it could be revitalised. Denis Diderot was critical of allegorical representations, but according to Antoine De Baecque this criticism was directed at making allegories clearly comprehensible and reinforcing the immediacy of the relationship between the personification and the moral idea. ${ }^{151}$ While Johann Joachim Winckelmann (1717-1768) is more well-known for championing Greek art and encouraging the neoclassical revival, he also published an essay On allegory in 1766. Although he thought allegories should use classical sources, he recognised that "allegory is indispensable in art and the designation of things and countries which were unknown to the ancients and new events and occurrences require new symbols". ${ }^{152}$ He argued that allegories should have simplicity, clarity and grace:

Simplicity consists in the design of an image which, with as little drawing as possible, expresses the thing to be given significance ... Clarity arises from simplicity, but ... one cannot expect a completely untutored person to understand a painting completely at first glance ... The images should be graceful, in accordance with the aim of art, which is to delight and amuse. But grace consists in choosing images which have nothing indecent, ugly or horrible in them. ${ }^{153}$

Allegory returned to favour in part because of the renewed interest in the classical world, but all the writers on allegory also defended it because of its useful instructional role. ${ }^{154}$

Personifications of three continents (Europe, Asia, and Africa) originated in classical times. Occasionally men represented the continents, but women were more usual, and all the personifications are female in the books in this study. Their depiction in art became common after European explorers 'discovered' America, and a personification of America was added to make four continents or 'four parts of the world' as they were usually called at the time. Clare Le Corbeiller believes the continents may have become popular through Renaissance pageants; in particular, when cities welcomed visiting princes

\footnotetext{
${ }^{151}$ Antoine De Baecque, 'The allegorical image of France 1750-1800: a political crisis of representation' Representations, 47 (Summer 1994), p. 122.

152 Johann Joachim Winckelmann, Writings on art, David Irwin (ed), London: Phaidon, 1972, p. 150.

153 ibid, pp. 145-146.

${ }^{154}$ De Baecque, p. 119.
} 
they would often stage tableaux vivants, and "it was not long before the Four Continents regularly acknowledged the supremacy of the visiting prince". ${ }^{155}$ Europe is commonly depicted wearing a crown and imperial purple and surrounded by classical architecture, objects of the arts and sciences, Christianity, and war. Asia is clothed in rich fabrics and accompanied by an urn of burning incense and sometimes animals such as the camel. Africa is either depicted as a black person (usually a woman) from central or southern Africa or a whiter-skinned woman from northern Africa. She is quite often naked or lightly clothed and usually surrounded by animals, serpents and birds.

As Central and South America were explored by Europeans before North America, the clothing and animals of these tropical countries became the attributes for the personification of America. One of the earliest images of Native Americans was a German woodcut of Tupinamba (Brazil) Indians engaged in cannibalism, and dressed in feather skirts and headdresses. ${ }^{156}$ This derived from descriptions in Amerigo Vespucci's account of America - woodcut illustrations were made to accompany various editions of this account. All of these items - the feather skirt and headdress and parts of bodies - would become standard attributes of the personification of America, although sometimes she was depicted naked. A bow and arrows and various 'typical' animals were also soon added. The birds and animals included the parrot or macaw, turtle, armadillo, tapir, sloth, jaguar, and alligator. These were not always depicted accurately and were sometimes confused with some of the 'typical' African animals such as the rhinoceros, lion and elephant. The bow and arrows and body parts, signifying cannibalism, show the European view of the 'savage' nature of the continent. When the four continents are depicted together, Christian Europe is often in a superior position - for example, on a throne - and clearly intended to be read as more 'civilised' than the others. Her attributes are cultural (human) products whereas Africa's and America's are natural. Asia has a mix of the two, but the cultural products are those associated with luxury. The European discoveries and conquests of the sixteenth century slowly established the idea of the four continents, but also that Europe was superior to the others. ${ }^{157}$

\footnotetext{
${ }^{155}$ Clare Le Corbeiller, 'Miss America and her sisters: personifications of the four parts of the world', The Metropolitan Museum of Art Bulletin, 19(8) April 1961, p. 209.

${ }^{156}$ Hugh Honour, The new golden land: European images of America from the discoveries to the present time, New York: Pantheon Books, 1975, p. 12.

157 ibid, p. 92.
} 
One of the first modern atlases depicted the continents in its title page. In 1570 Abraham Ortelius (1527-98) produced Theatrum orbis terrarium, a collection of 70 maps that was a huge success, reprinted many times and translated into six languages by 1612 . As well as the four continents, a bust of a woman, with a flame on the plinth, was also depicted. Ortelius explained this was the fifth continent yet to be fully known, which his world map depicts as a vast extension of Tierra Del Fuego (she is often called Magellanica). ${ }^{158}$ Cesare Ripa's Iconologia first published in 1593, but not illustrated until 1603 , became the handbook to which many artists turned for depictions of personifications. Where possible, he drew on classical sources. The first edition illustrated with woodcuts, depicted Europe with attributes of power - a crown and sceptre - holding a temple (signifying Christianity) and with implements of war and a cornucopia (symbolising abundance). Asia was well-dressed, holding an incense burner and plants, with a camel beside her. Africa was clothed in a simple tunic with a headdress in the shape of an elephant's head; she held a scorpion and a cornucopia, and was accompanied by a lion and a snake. America, partly naked, had some feathers in her hair, held a bow and arrows, stood on a European head (with an arrow through it) and was accompanied by a large reptile. ${ }^{159}$

Personifications of the continents appeared in a variety of media - tapestries, ceramics, paintings, and sculpture. Perhaps one of the most famous and largest of the eighteenth century was Giovanni Battista Tiepolo's (1696-1770) ceiling fresco completed in 1753 in the Residenz in Würzburg. The order in which the continents are viewed by a person coming up the stairs emphasised the European view of a progression towards civilisation. From the bottom of the stairs only America and a part of heaven above could be seen - Apollo as sun god (and metaphor for the ruling prince-bishop) is oriented to be seen from this direction and thus appears to rule over America. At the first landing as the viewer turned around they would face Europe, with Africa on the left and Asia on the right. By turning, Apollo and the greater part of heaven are no longer oriented to the viewer so it becomes more generalised and Europe appears to dominate. From this viewpoint the gestures of Asia and Africa also appear to refer to Europe. ${ }^{160}$ Although Tiepolo follows Ripa's iconography in some respects, he deviates from it in others and is likely to have

\footnotetext{
${ }^{158}$ Cosgrove, 2001, p. 131

${ }^{159}$ Described from the illustrations in Le Corbeiller, 1961.

${ }^{160}$ Svetlana Alpers and Michael Baxandall, Tiepolo and the pictorial intelligence, New Haven \& London: Yale University Press, 1994, pp. 115-118.
} 
sourced many of the extra details from travel accounts. ${ }^{161}$ He rarely indicates geographical place by the clothing or physical appearance of people (for example, there are a number of figures wearing turbans in the America fresco); this is more likely to be indicated by activities, animals or the use of 'standard' attributes. Most of the costumes and facial types he had used for many years.

The frontispieces of the books I have chosen to study are allegories or personifications of the four continents. The books include some English universal geographies and various editions of French costume books by Jacques Grasset de SaintSauveur (1756-1810), mainly from the late eighteenth century. The universal geographies are by Thomas Bankes et al, Charles Middleton, and George Millar published in 1790, 1777, and 1782 respectively. ${ }^{162}$ Published in a number of editions, they often have a similar appearance and sometimes contained very similar illustrations and text. Saint-Sauveur's books are organised by continent, with Europe first, thus showing the primacy accorded to Europe; then followed by Asia, Africa and America - the Oceanic peoples are located at the end of America. ${ }^{163}$ The English books are, however, organised in a variety of ways. Bankes's volume focuses on the recent voyages and therefore begins with Oceania, followed by Asia, Africa, America and Europe. Middleton orders his work by continent, and interestingly starts with Asia, followed by Africa, Europe and America. This is not because the English authors regarded the position of Europe any differently than the French, but reflected a biblical view, as Middleton explains:

We shall begin with a description of Asia, for here it was according to the holy writings that the Divine Being created the first of the human race ... the descendants of Noah ... [made] their first migrations into Africa, which will be the second object of our consideration. When the Asiatic and African regions became the seats of tyranny and despotism, some of the more liberally disposed penetrated northward ... Hence Europe, though less extensive and wealthy, became more polished and powerful than the other two parts of the world. Till at length the inhabitants made such astonishing improvements in the arts and sciences, and became so bold in the spirit of enterprise, that they discovered the fourth grand division of the globe, America.

\footnotetext{
${ }^{161}$ Mark Ashton, 'Allegory, fact, and meaning in Giambattista Tiepolo's four continents in Würzburg', The Art Bulletin, 60(1) March 1978, pp. 109-125.

162 See Bibliography, Primary Sources, for the details of these books.

163 The only exception I have seen is the 1795 four-volume Encyclopaedia in the Mitchell Library, Sydney, which mixed countries and continents. The plan of the work explained that each volume would contain the ' 4 parts of the world' and left the order of binding to the binder or purchaser's discretion.
} 
This shows the Europeans' belief that they were more liberal, civilised and powerful and, by implication, justified taking the riches, including slaves, from the other parts of the world, which the text from the frontispiece, quoted at the head of this chapter, made explicit. The Oceanic peoples are located at the end of America. Millar follows the same order as Middleton - Asia, Africa, Europe and America - except the Oceanic islands follow Asia. The Oceanic peoples initially were almost always seen as an extension of America. Europeans regarded the Americas as the 'new world' so it was an obvious extension to add these 'newer' peoples to the new world. Also most early voyages came into the Pacific via the Atlantic and the Americas.

Europe's attributes - items associated with arts and sciences, and sometimes war and commerce - indicate that Europeans saw their own continent as the measure of civilisation. Saint-Sauveur's personification of Europe includes a helmet and spear, a globe, books, artist's palette and brushes, and various scientific instruments. Two putti hold some of the emblems (they signify genius - in the sense of creative spirit / inspiration - and in particular the flames on their heads symbolise thoughtfulness, according to Ripa). The 1796 edition has a ship flying a French flag in the background (fig. 5), whereas the 1806 edition has classical columns and the sun on a cloth, representing Enlightenment (fig. 6). The two images are similar but with the position of Europe and the putti reversed. In the 1806 image Europe wears the helmet instead of resting her hand on it and the globe is also more prominent, but whether this is to show her as more imperial, in keeping with the Empire declared by Napoleon Bonaparte in 1804, or simply for variety, is not known.

Middleton and Bankes both follow the biblical account, and therefore credit Asia with the first humans. Both make positive comments about Asia in their one-page introductions, although these are not necessarily maintained when each country is discussed. Saint-Sauveur is more influenced by the French Enlightenment and in his Asia introduction says: "Echoing all the geographers, we say that Asia received men before the rest of the earth. We are far from affirming it. It is only one conjecture which has only some probabilities". ${ }^{164}$ In general, the Europeans considered Asia to be second to Europe in its

\footnotetext{
${ }^{164}$ French spelling as in the original text: "Echo de tous les géographes, nous disons que l'Asie a reçu des hommes avant le reste de la terre. Nous sommes loin de l'affirmer. Ce n'est qu'une conjecture qui n'a pour elle que quelques probabilités.” Jacques Grasset de Saint-Sauveur, Encyclopédie des voyages ..., Paris: se trouve chez l'Auteur ... chez Deroy, libraire ... Et chez les principaux libraires de la République, 1796, ATL, Asie introduction, vol. 3, p. 2.
} 
level of 'civilisation'- it had some luxury products such as silks and pearls, and some cultures with ancient histories such as China, but its better days were thought to be over and it was now considered the home of despotic government and indolence. Saint-Sauveur says in his 1796 Asia text: "In general the Asians are weak, indolent, love ostentation, slow and patient ... If there is despotism there since the 'good old days', it is because the governed are too lazy to shake the yoke and break the chains". ${ }^{165}$ Saint-Sauveur's personification of Asia encapsulates these attitudes in her reclining position on a divan and her feet on a cushion, her fur-trimmed gown, jewellery, the swathes of curtains and the incense burner behind her. The 1796 edition (fig. 7) and the 1806 edition are very similar, but again reverse the position of the Asia figure.

In Saint-Sauveur's personifications, only Africa and America are depicted with animals, thus showing their closer links with nature, savagery and the exotic. Africa is a very similar representation in both the 1796 (fig. 8) and 1806 editions; she has one breast exposed, and as with America, has a bow and arrows. Africa sits on an animal fur with a lion at her feet. In the 1788 edition of Sylvain Maréchal and Saint-Sauveur's Costumes civils, America is depicted with all the typical attributes (except the gold); and a pelican, tortoise, possibly a beaver and various plants are added (fig. 9). ${ }^{166}$ Claude-Louis Desrais designed this image and it is a different composition from the 1796 and 1806 edition frontispieces of America. In these later two editions, the figure of America takes up a larger portion of the composition than in the 1788 edition. The 1796 America (fig. 10) shows a bare-breasted woman looking over her shoulder. She wears a feather headdress and feather skirt, carries a quiver of arrows and rests a bow in the other hand. A beaver, tortoise and

\footnotetext{
165 "En général, les asiatiques sont mous, indolens, amis de faste, lents et patiens. Si le despotisme y est dans ses beaux jours c'est que les gouvernés sont trop paresseux pour secouer le joug et briser leurs chaînes." Saint-Sauveur, Asie introduction, 1796, vol. 3, p. 5.

${ }^{166}$ Costumes civils actuels de tous les peuples connus, dessinés d'après nature, gravés et coloriés..., Paris: chez Pavard, 1788, 4 vols. Although the 1788 edition is credited to Sylvain Maréchal alone, the royal privilege and approbation were granted to Saint-Sauveur in 1784 (this is included in vol. 1). His name appears on only a few images as "inv" (invenit - literally 'invented it'; designer). On some other images the names given are Desrais "del" (delineavit - drawer) and Mixelle "sculp" (etcher/engraver). Many of the images have no names, but as some of these are different from the equivalent images in Saint-Sauveur's other books it seems Claude-Louis Desrais (1746-1816) added to (or sometimes substituted his own designs for) Saint-Sauveur's. It appears that once Saint-Sauveur sold the rights, the book was published without his name. (See Hilaire and Meyer Hiler, Bibliography of costume: a dictionary catalog of about eight thousand books and periodicals, Adah V. Morris (ed) NY: B. Blom, 1967, p. 390. Also the entry on Desrais in Roger Portalis, Les dessinateurs d'illustrations au dix-huitième siècle Paris: Morgand \& Fatout, 1877, vol. 1, p. 176, says this book was by Saint-Sauveur, and the Bibliothèque Nationale in Paris has it catalogued as by Saint-Sauveur and Maréchal.)
} 
gold are shown, along with a few schematic plants. The 1806 America (fig. 11) has the same pose as the 1796 woman except reversed, but now she wears a knee-length tunic and the plants have given way to a cloth and a ship (a similar ship to that in the background of Europe in the 1796 edition). Also, the gold is replaced by what appear to be cannonballs and a ship's anchor. America now sits on a neoclassical stone seat as compared to the wooden box seat of the 1796 edition.

The overall impression is that America has become more 'civilised' between the two editions - she is more involved in commerce, and more divorced from the natural environment. This is highlighted even more by the fact that none of the other three continents changed much between the 1796 and 1806 editions. It is possible that the 1806 edition is intended to represent a North American woman compared to the traditional personification, based on a South American woman, of the 1796 edition. According to McClung Fleming, the changing political status of the British colonies of North America to independence caused the image of America to also change, for example, it was common from about 1765 to 1785 to depict America as a North American Indian woman, sometimes with a tomahawk and knife instead of the bow and arrows. ${ }^{167}$ However, Saint-Sauveur's 1796 edition is 13 years after America achieved her France-assisted independence, and yet shows no evidence of this. He may have continued to use an earlier image, which by the 1806 edition was just too outmoded and therefore redrawn. But even in the 1788 edition, where it might be assumed America was a new design by Desrais, she appears with all the traditional attributes and luxurious plants of tropical South America. One indication of why the allegory of America may have been so slow to change is a French allegorical painting from 1784 in which France offers Liberty (a partly naked woman) to America (here depicted as an American Indian man) who is shown gratefully receiving it. ${ }^{168}$ This suggests that the Americans were not considered capable of winning liberty for themselves but had it bestowed by one European power (France) against another (England).

\footnotetext{
${ }^{167}$ E. McClung Fleming, 'The American image as Indian princess 1765-1783', Winterthur portfolio, 2, 1965, pp. 65-81.

${ }^{168}$ Jean Suau (1758-1856), La France offrant la liberté à l'Amérique, Musée franco-américain du château de Blérancourt, oil on canvas (illustrated in D'un regard l'autre: histoire des regards européens sur l'Afrique, l'Amérique et l'Océanie, Paris: Musée du Quai Branly, exhibition catalogue under the direction of Yves Le Fur, 2006, p. 139).
} 
There is a similarity between Africa and America and two Amazons depicted by Saint-Sauveur (Amazône d'Afrique and Guerrière de la rivière des Amazônes) (fig. 12). This is perhaps not surprising, as this race of women from Greek mythology was thought to have parallels in the 'savage' races of America and Africa. Saint-Sauveur's 'Amazônes' text explains that at least one author described finding Amazons near Ethiopia in Africa, but "the only Amazon people whose current existence is quite certain" are those near the river of the same name in South America. ${ }^{169}$ The Amazons were a legendary race of warlike women, who excluded men from their society. Various Greek heroes (for example, Hercules, Theseus, Achilles) killed Amazon queens and fought with Amazon warriors, thus establishing civilised (male) power over wild savagery (female). America, in particular, was often thought of as an Amazon warrior and therefore in need of conquering and civilising. In some depictions of America she appears to passively invite European possession and civilisation.

Whereas Saint-Sauveur uses a frontispiece at the beginning of each continent and therefore depicts each personified continent separately, the three English books in my study have one initial frontispiece which depicts all four continents together. These more obviously show the relationships among the continents as they were seen by Europeans at the time. Middleton's frontispiece (fig. 13) shows the continents with their typical attributes - Europe sits on a throne, with emblems of the arts and sciences around her; Asia, Africa and America wear or carry the items mentioned in the text below the frontispiece, clearly intended as tribute to Europe. However, even more imperialistic is Thomas Bankes's frontispiece where the four continents are shown presenting their tribute to Britannia (fig. 14). Alan Bewell believed Bankes's frontispiece was the first to show a personification of the 'South Pacific' (probably a Tahitian woman) offering a bouquet of flowers to Britannia. ${ }^{170}$ I disagree with this interpretation. I believe the woman with the 'bouquet' is Europe holding a cornucopia (it contains a necklace as well as flowers) - a standard

\footnotetext{
169 "Le seul peuple d'Amazones dont l'existence actuelle soit bien certaine et bien incontestablement établie, est celui que les voyageurs ont découvert au fond de l'Amérique, auprès de la rivière qu'ils ont nommé, par cette raison, rivière des Amazones." Amazones, 1796, vol. 5, p. 6.

${ }^{170}$ Alan Bewell, 'Constructed places, constructed peoples: charting the improvement of the female body in the Pacific' in 'The South Pacific in the eighteenth century: narratives and myths'. Papers from the ninth David Nicol Smith memorial seminar; Jonathan Lamb, Robert Maccubbin \& David Morrill (eds), Eighteenth-century life, 18(3), Nov 1994, p. 41.
} 
attribute for Europe; she also wears a tiara. At the bottom of the image, Bankes includes the following text to explain the symbolism:

Neptune raising Capt Cook up to Immortality, a Genius crowning him with a wreath of Oak and Fame introducing him to History. In the front ground are the Four Quarters of the World presenting to Britannia their various stores.

This indicates that the four women shown are the usual four continents (Europe, Asia, America and Africa). Although it may seem unusual to separate Britannia from Europe, after England's victories against France in the Seven Years' War (1757-1763) it was perhaps not unexpected for an English book celebrating maritime discoveries to show Britannia victorious. At least Europe is depicted on an equal level with Britannia whereas the other three are all subservient to differing degrees (especially America, who is almost obscured behind Britannia's throne). There is no indication of the fact, as it was when this edition was published in 1790, that the American colonies had won independence from England. It is probable that he has continued to use an image from earlier editions as was quite common in book publishing of the time to save time, effort and hence money. ${ }^{171}$ In Millar's frontispiece (fig. 15) Britannia is represented as a statue. As explained in the text beneath the image, Geography writes this book in front of Britannia, while Neptune introduces the four parts of the world who bring various produce and curiosities from their respective countries. Mercury hovers above and carries an emblem with the words 'new discoveries and valuable improvements'. Europe is depicted with a cornucopia. Again, it is viewed as quite natural that Europe receives the products of the other continents.

The English frontispieces are more explicit than Saint-Sauveur's in showing the power relations between the continents as seen by Europeans. Although this can be seen in Saint-Sauveur's images, it becomes more apparent when read with his texts introducing each continent. Europe is described as the "the mother of all arts and sciences; and the homeland of great men ... it must be admitted that Europeans surpass other nations by their bravery as much as by their knowledge and their philosophy". ${ }^{172}$ Africa is seen as a place with cruel punishments and bizarre customs. Notions of what Europeans regarded as

\footnotetext{
${ }^{171}$ The 1787 edition, at least, had the same frontispiece as it is illustrated in Bernard Smith, 'Cook's posthumous reputation', in Captain Cook and his times, Robin Fisher and Hugh Johnston (eds), Vancouver \& London: Douglas \& McIntyre / Croom Helm, 1979.

172 'L'Europe est la mère de tous les arts, de toutes les sciences; c'est la patrie des grands hommes ... alors il faut convenir que les Européens surpassent les autres nations par leur bravoure autant que par leurs connoissances et leur philosophie". 1796, Europe introduction, vol. 1, p. 3.
} 
beautiful and ugly are embedded in all the descriptions of people - there is no hesitation in saying that the peoples of whole countries have deformed faces or are ugly, for example. Flat noses of Africans are explained by mothers carrying newborns on their backs where the babies' noses are flattened imperceptibly. 'Blackness' is an aberration that needs explaining and he offers some of the theories of the age, but most often refers to climate. These ideas are not unique to Saint-Sauveur - a negative image of Africans was commonly held, even by supposedly enlightened philosophers (even Saint-Sauveur's explanation for flat noses was a common one). ${ }^{173}$ America, however, is said to excel both Africa and Asia in its cruel 'fashions' and, repeating ideas common at the time, Saint-Sauveur says that animals and people have degenerated in America. Nothing at all is said of Oceanic peoples in these introductions to the four continents, although they were included with America.

Little of the turbulent political times in which Saint-Sauveur's books were published is reflected in these frontispieces or the introductions. There is not much change in the introductory texts between the 1796 and 1806 editions - 1806 is mainly a muchabbreviated form of 1796. He can say in both editions (in the Europe introduction) that Europe "conquered America and holds it under its yoke with as much facility as the Roman Empire held Corsica and Sardinia". ${ }^{174}$ This is after the United States has won independence; France has lost its most prosperous colony of Saint-Domingue (Haiti from 1 January 1804) and sold the large tract of land known as the 'Louisiana purchase' (1803) to the United States; and slavery had been abolished under the French revolutionary government in 1794, but a few years later re-imposed in the French colonies by Napoleon. If the image of America represents a more 'civilised' view in the 1806 edition, there is little corroboration of it from his texts. There is a small section of new information in the America introduction to the 1806 edition - he lists some of the principal exports of America, which may explain why he included the ship in the background. He also lists which European powers possess colonies in the Americas, but there are two inaccuracies at the time of publication - he still includes Saint-Domingue as a French colony, and he says

\footnotetext{
${ }^{173}$ Cohen, 1980.

174 "Elle a conquis l'Amérique, et la tient sous son joug avec autant de facilité que l'empire Romain tenoit la Corse et la Sardaigne." Europe introduction, 1806, p. 2. (These islands were under Roman occupation for nearly 700 years.)
} 
Spain yielded Louisiana to the United States. ${ }^{175}$ This suggests the text was written before 1800 and not updated for the 1806 publication; which no doubt reflected the exigencies of publishing rather than politics.

The fact that the attributes of the four continents became standard by the early seventeenth century and lasted well into the nineteenth says more about a European world view than anything about the continents themselves. Even when new knowledge became available (or new images from recent voyages) the personifications were not usually changed, as they needed to be recognisable to a European audience. America, which at this time usually included Oceania, was generally depicted as a 'savage' although she is tending to become more 'civilised' by the later eighteenth century. The earlier view of America was becoming increasingly outmoded after American independence in 1783. Despite the illustrated encyclopaedias including the latest Oceanic discoveries, on the whole their frontispieces remain traditional, and by subsuming Oceanic peoples under America, they say practically nothing about this part of the world. As a summary of the narrative of the book, the frontispieces therefore could be seen as incomplete, but they also clearly reveal European views of their own superiority, which colours their views of the other parts of the world. The next two chapters will look in detail at the other images in the books; beginning in chapter 4 with a consideration of how Saint-Sauveur designed the images of Oceanic peoples in his costume books in relation to their sources.

\footnotetext{
${ }^{175}$ France ceded Louisiana to Spain following the Seven Years' War in 1763. Spain and the United States signed a treaty in 1795 giving some recognition to US interests, which may be what Saint-Sauveur is referring to. France regained control of Louisiana in 1800, but sold it to the United States in May 1803 after Napoleon gave up his ‘western design’ having lost Saint-Domingue.
} 


\section{Chapter 4 - Inventing Oceania for the costume books}

We have permitted ourselves to suppress the absurd parts of a picture which is only intended to offer pleasant objects to the eyes of the public. ${ }^{176}$

Following the end of the Seven Years' War in 1763, exploration in Oceania received the renewed attention of England and France. Voyagers' accounts provided Europeans with alternative societies to compare with their own. While some of the voyagers wrote positively about the Oceanic peoples, or tried to be objective, they nevertheless saw them as 'primitives' or 'savages' and, whether overtly or not, ranked them in terms of their progress towards 'civilisation', which was measured by their own conceptions. It had been fairly common to compare American Indians to earlier stages of European societies - the 'savage Picts' for example - whereas Tahitians were often compared to classical Greeks. This was sometimes also reflected in art, and said more about the revival of European interest in classical arts and culture at the time than it did about the Tahitians. While some of the voyagers, and subsequently philosophers, used the Oceanic peoples to criticise aspects of European society, the more popular illustrated encyclopaedias were more interested in selling books by aiming to inform and entertain. This chapter looks at the images of Oceanic peoples that appeared in French costume books from the mid1780s in relation to their sources. It also discusses a French panoramic wallpaper, which used these costume books as one of its sources. The French costume books were following a tradition that emphasised clothing and adornments and their sources are just as likely to have included other costume books as the voyage accounts. The chapter will argue that, in inventing images that were designed to please the eye, the sources chosen reveal the prejudices and expectations of European readers.

All of the illustrated encyclopaedias and decorative arts considered in this study used recent voyage accounts as sources of information for Oceania, so it is first worth briefly considering some of these accounts. Between the end of the Seven Years' War and the outbreak of the French Revolution, Britain and France experienced what Peter Marshall and Glyndwr Williams called a 'Pacific craze' during which naval explorers and scientists

\footnotetext{
${ }^{176}$ Art Gallery New South Wales and National Gallery of Australia, Les sauvages de la mer Pacifique: Manufactured by Joseph Dufour et cie 1804-05 after a design by Jean-Gabriel Charvet. Sydney \& Canberra: AGNSW/ NGA, 2000, translation of prospectus for panoramic wallpaper, p. 38.
} 
became national heroes. ${ }^{177}$ The voyages were part of a scientific, commercial, and colonial competition among the two principal European powers that later included America and Russia. The first English voyages of the 1760s by John Byron, Samuel Wallis and Philip Carteret were soon eclipsed by the three voyages of James Cook (between 1768 and 1780), and for Tahiti, the French voyage (1766-69) under Louis-Antoine de Bougainville.

Bougainville's Voyage autour du monde was published in 1771, containing only a few illustrations. The naturalist on Bougainville's voyage, Philibert Commerson (17271773), disembarked at Mauritius on the return voyage and from there wrote an exceedingly positive account of Tahiti, which notably was published well ahead of Bougainville's official account - in the Mercure de France in November 1769. Commerson's account (in which he called the island 'Utopia') described the Tahitians as without vices, prejudices or needs and went on to say:

Born under the most beautiful sky, nourished by the fruits of a land that is fertile without needing to be cultivated ... they know no other god than love; each day is dedicated to her, the island is her temple, the women are the idols and the men the worshippers. ${ }^{178}$

Nevertheless, he was aware the Tahitians were not as selfless as he portrayed them and he did not mention the violent incidents which occurred during the nine days of their stay in Tahiti. His account had a political purpose, according to Harry Liebersohn, "he wrote with a passion for social improvement". ${ }^{179} \mathrm{He}$ was one of the first voyagers, or philosophers, to use Oceanic information as a means of criticising, and seeking improvements to, his own society. He also helped establish the myth of Tahiti as the 'island of love'.

The official account of Cook's first voyage, written by John Hawkesworth under the title An account of the voyages undertaken by...Commodore Byron, Captain Wallis, Captain Carteret, and Captain Cook, was not published until June 1773. It had 20 plates of views, peoples and artefacts collected or seen on Cook's voyage (another three plates were included in volume 1 covering the earlier voyages). The main artist on Cook's first voyage

\footnotetext{
${ }^{177}$ Peter J. Marshall and Glyndwr Williams, The great map of mankind: British perceptions of the world in the age of Enlightenment, London, Melbourne \& Toronto: J M Dent \& Sons, 1982, p. 258.

178 Philibert Commerson, Mercure de France, November 1769, Geneva: Slatkine Reprints, 1968, vol 97. "Nés sous le plus beau ciel, nourris des fruits d'une terre qui et féconde, sans culture, régis par des pères de famille plutôt que par des Rois, ils ne connoissent d'autre Dieu que l'amour; tous les jours lui sont consacres, toute l'Isle est son temple, toutes les femmes en sont les idoles, tous les hommes les adorateurs."

${ }^{179}$ Harry Liebersohn, The travelers' world: Europe to the Pacific, Cambridge, Mass. \& London: Harvard University Press, 2006, p. 28.
} 
was Sydney Parkinson (c.1745-1771) - employed by Joseph Banks for natural history drawing he also had to illustrate landscapes and people after Alexander Buchan died soon after arriving at Tahiti. As Parkinson also died later on the voyage, a number of his drawings were 'worked up' into scenes by Giovanni Battista Cipriani (1727-1785; a neoclassical history painter) so they could be engraved for the official publication. Parkinson's brother also published in 1773 Parkinson's Journal, illustrated with 27 plates, after a long dispute between Stanfield Parkinson and Joseph Banks over ownership of the material. ${ }^{180}$ The official publication of Cook's second voyage (1772-75) appeared in 1777 and was edited by John Douglas (who also edited the third voyage account). William Hodges (1744-1797) was the official artist on the second voyage and the official publication was illustrated with more than 60 plates. There were also other publications, including two from the naturalists on board - Johann Reinhold Forster and his son George. Johann's account, Observations made during a voyage round the world, was published in 1778, while George's had appeared in March 1777; some weeks before the official account was published at the end of April 1777. In commenting on, and comparing, the Oceanic peoples, Johann took the following as some of the key indicators of relative civility: principles, moral ideas, manners, refinement, luxury, and the condition of women. The Society Islanders (French Polynesia) were seen as comparatively civilised (and 'feminised') in contrast to the manly, but fractious barbarism of the New Zealanders; whereas the Friendly Islanders (Tonga) were more difficult to place - they were praised for their industry and were seen to possess the capacity for 'progress', but appeared to have a political organisation of more servile submission. ${ }^{181}$

The official account of Cook's third voyage was published in 1784 and such was its popularity that the first edition sold out in three days, even at the high price of four and a half guineas. The second and third editions were published the following year, as well as pirated editions and a French translation. ${ }^{182}$ The commercial opportunities from this voyage were soon recognised, as in 1785 the first fur-trading ship arrived at Nootka Sound. In fact, Currie argues that the editor John Douglas (a clergyman) focused on trade as the primary

\footnotetext{
${ }^{180}$ Rüdiger Joppien and Bernard Smith, The art of Captain Cook's voyages, Melbourne: Oxford University Press 1985-7, Vol 1 - The Voyage of the Endeavour, pp. 53-54.

${ }^{181}$ Guest, 2007, pp. 13, 22, 106-107, 121.

${ }^{182}$ Currie, pp. 26-27. However, there were still many copies of the third edition available in 1801 , and the publisher reported that little profit had been made on the whole publication (Marshall \& Williams, 1982, p. 56.) This supports the argument in chapter 1 that European interest in 'exotic' peoples waned quickly.
} 
form of contact between the ship and shore to eliminate potentially offensive material (e.g. sexual encounters) that was the cause of the scandalous reception of Hawkesworth's editing of Cook's first voyage account. ${ }^{183}$ The official artist on the last of Cook's voyages was John Webber (1753-1793) and the official publication had 61 plates. There are a number of reasons for the popularity of Cook's voyages, but the lavishly illustrated publications must surely account for some of it - especially as accounts of other voyages at the time were not well illustrated. The French voyage (1785-88) led by Jean-François de La Pérouse might have made up for this, but his ships disappeared in June 1788 and it was only four decades later that pieces of the shipwreck on the island of Vanikoro were discovered. Although some written material and illustrations had been sent back to France, given the political turmoil of the revolutionary years an account of the voyage was not published until 1797 (in English in 1798). And in 1799/1800 the Atlas resulting from Bruni d'Entrecasteaux's voyage to search for La Pérouse was published.

Grasset de Saint-Sauveur's first costume book was published in 1784, the same year the official account of Cook's last voyage appeared. ${ }^{184}$ The Turnbull Library's copy of this edition contains only Tahiti, Marquesas Islands and St Christine (one of the Marquesas Islands). Yet, at least two of the images are partially sourced from engravings after John Webber so it was using some very recent images as sources. These are Fille Taïtienne portant des present au roi (Girl carrying presents to the king) and Danseuse de Taïti (Tahitian dancer) (figs. 16 and 17). ${ }^{185}$ The Tahitian dancer appears to combine elements from the engraving after Webber (fig. 18) - in particular her skirt and its 'tassels' - with other elements from the dancers in a plate designed by Cipriani based on drawings by Parkinson in the first voyage account (fig. 19). This is an image showing three dancers, some musicians and audience and was used by Saint-Sauveur as a source for his 'Tahitian man' and 'Tahitian girl'. ${ }^{186}$

\footnotetext{
${ }^{183}$ Currie, p. 77.

${ }^{184}$ For a discussion of Saint-Sauveur's books see Roger Collins, 'Jacques Grasset de Saint-Sauveur', Turnbull Library Record, 17(1) May 1984, p. 29.

${ }^{185}$ As Anne Salmond explains, a high-ranking person was often greeted by a young girl swathed in layers of bark cloth, who slowly turned around unwinding it as she went. The image also includes two crescentshaped chiefly breastplates ('taumi'). Anne Salmond, Aphrodite's island: the European discovery of Tahiti, NZ: Penguin/Viking, 2009, pp. 19, 29, 99, 151.

${ }^{186}$ Some small images are inset in the text to make the comparisons easier to see; larger sized images are included with the figures at the end.
} 


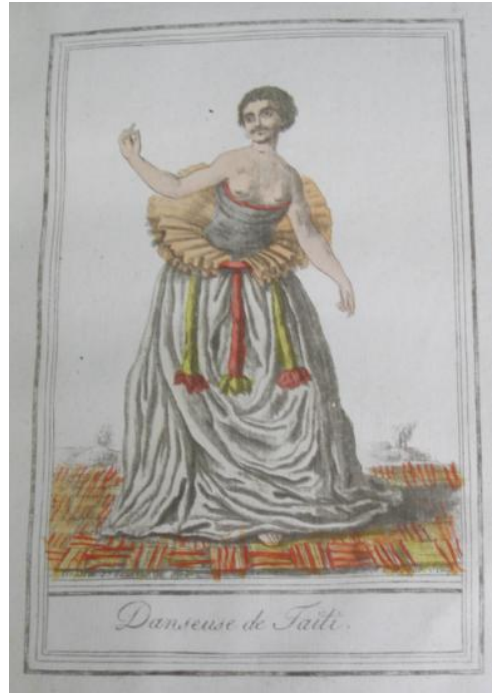

Fig. 17

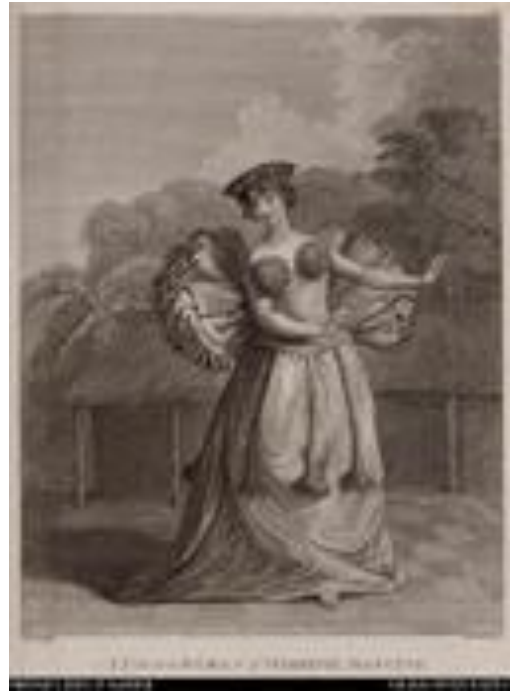

Fig. 18

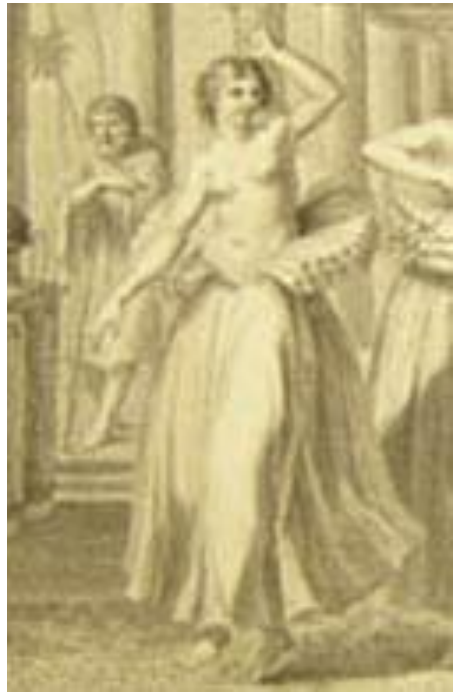

Fig. 19 (detail)

The Tahitian dancer in the 1788 edition, probably drawn by Desrais (fig. 20), is more closely modelled on Webber's dancer. Another example of the 1788 edition staying closer to the engraving after Webber (fig. 21) than other editions is the almost-naked male Sandwich Island dancer (Danseur des Isles Sandwich). The 1788 edition version (by Desrais?) even includes the hut and palm tree in the background, and although the dancer has a slightly different pose from Webber's the only adornments he lacks are the necklace and tattoos (fig. 22). Saint-Sauveur's 1796 version (fig. 23) gives the dancer more of a loin cloth, a cape, and a mask. The mask was illustrated separately by Webber, and also appeared in another illustration with canoeists wearing them, but not the dancer.

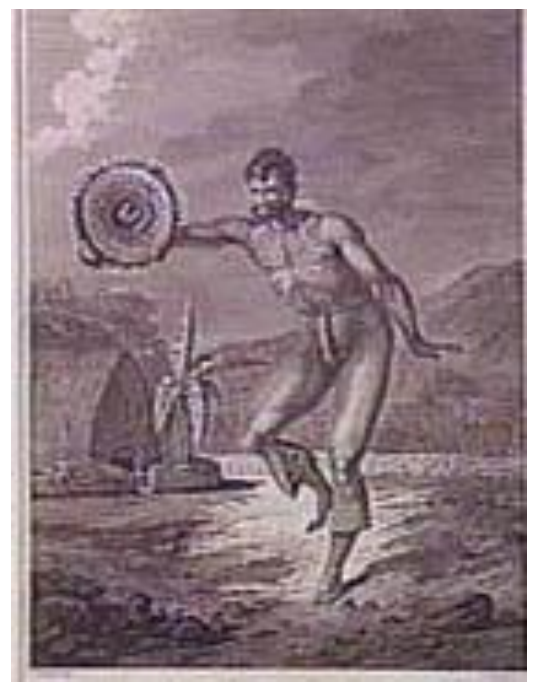

Fig. 21

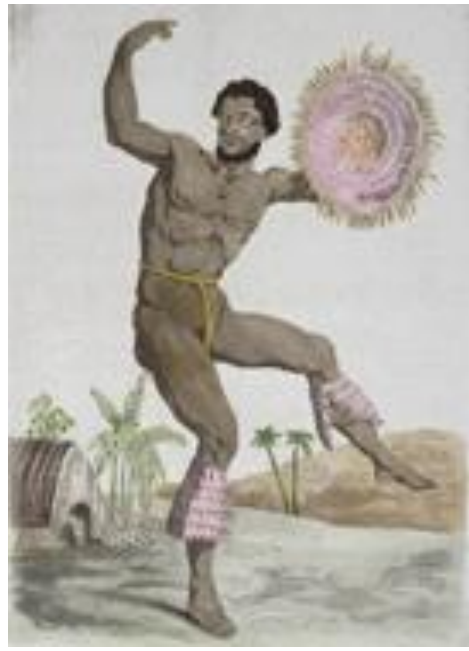

Fig. 22

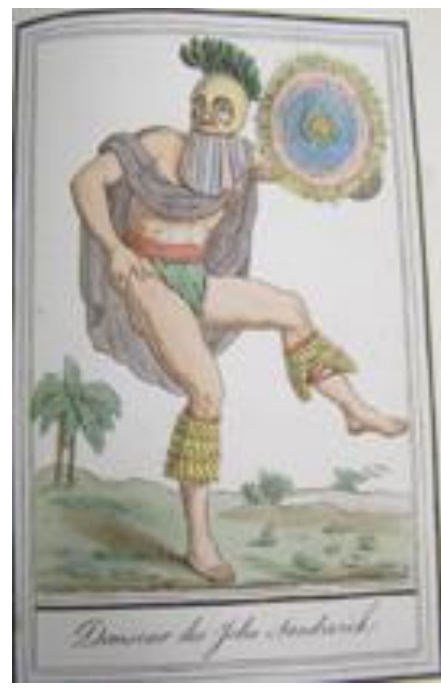

Fig. 23 
There are many examples where Saint-Sauveur combined elements from various sources. The Sandwich Island dancer is one and another example is the Sandwich Island warrior (Guerrier de Sandwich). Again, the 1788 edition differs from later editions and stays closer to the engraving after Webber. Assuming Desrais designed the 1788 image, he has used as his source the man on the far right of an engraving after Webber of The Death of Captain Cook (fig. 24). ${ }^{187}$ Perhaps to emphasise that it was Sandwich Island (Hawaii) warriors who killed Captain Cook, Desrais includes a small vignette of Cook's death in the background (fig. 25). A drawing for this image is also in the collection of the National Library of Australia (fig. 26). ${ }^{188}$ When we compare the 1788 image with Saint-Sauveur's 1796 Warrior (fig. 27) the pose is similar, however, Saint-Sauveur has added a helmet, which was probably based on an engraving after Webber of a Man of the Sandwich Islands with his helmet, although it also conforms to typical representations of a helmet from classical Greek art. He also used a different type of cape which, unlike Webber's and Desrais's, covers the buttocks.

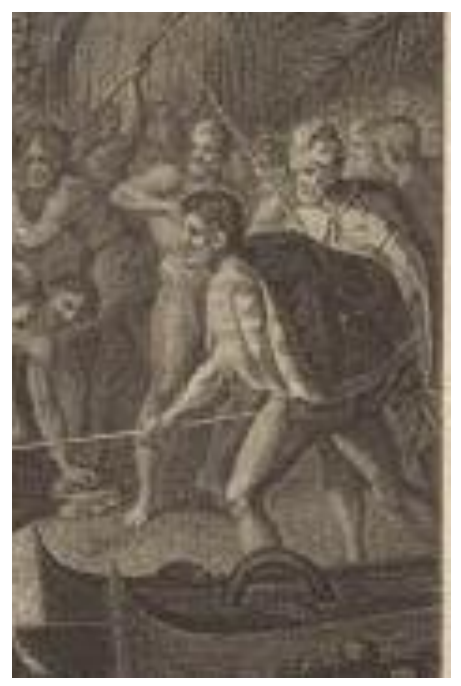

Fig. 24 (detail)

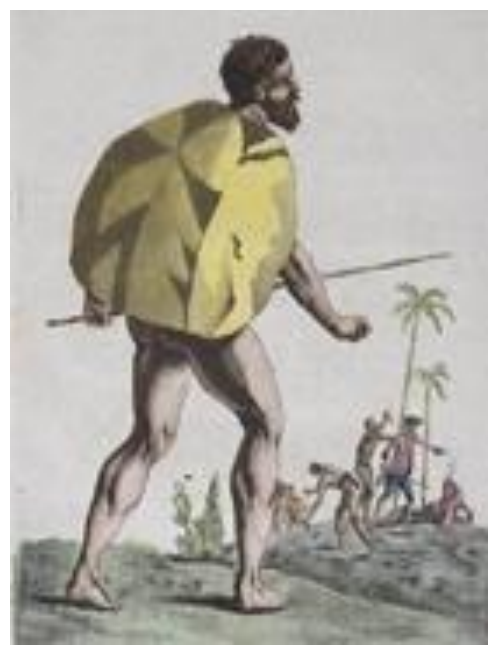

Fig. 25

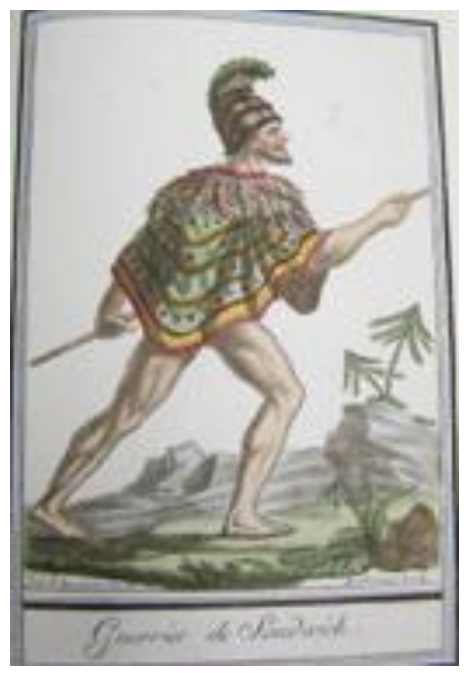

Fig. 27

187 As I have not seen the equivalent image from Saint-Sauveur's 1784 edition, I cannot be certain that the 1788 edition was not Saint-Sauveur's design; however it differs from the design in Saint-Sauveur's later editions (see also footnote 166 in chapter 3 for further discussion regarding the 1788 edition).

${ }^{188}$ Michelle Hetherington attributed this drawing to John Webber in the text (p. 37) although the caption stated 'unknown' (p. 36) in National Library of Australia, Paradise possessed: the Rex Nan Kivell collection, Canberra: National Library of Australia, 1998. Rüdiger Joppien said this drawing was "perhaps by St-Sauveur", 1979, p. 196. 
Saint-Sauveur borrows fragments from various sources - while a number of the voyage images were only head and shoulders portraits, Saint-Sauveur either makes up a body or adapts one from a general scene. For example, the heads of Saint-Sauveur's Homme et Femme de l'Isle de Tanna (Man and Woman of Tanna) (fig. 28) (an island in Vanuatu) are based on engravings of two of William Hodges's head-and-shoulder portraits, but some of the full-body elements are taken from a group of people in View in the Island of Tanna after Hodges (detail - fig. 29). In particular, Saint-Sauveur has used the pose of the man leaning on a club with one leg crossed over the other, and includes his arm-bands (or tattoos) but has also given him a leafy skirt, which only the women in the Hodges View wear. Did he include the skirt out of a sense of decorum or simply because it would be more interesting in a costume book if the man was wearing something? He is not averse to showing women's exposed breasts, as for example in the 'Woman of Easter Island' (discussed below) or in choosing to use the bare-breastedness of the Tahitian dancer of Cipriani rather than Webber's covered dancer for his Tahitian dancer (fig. 17). Was this what his readers would have expected to see of 'savage' women?

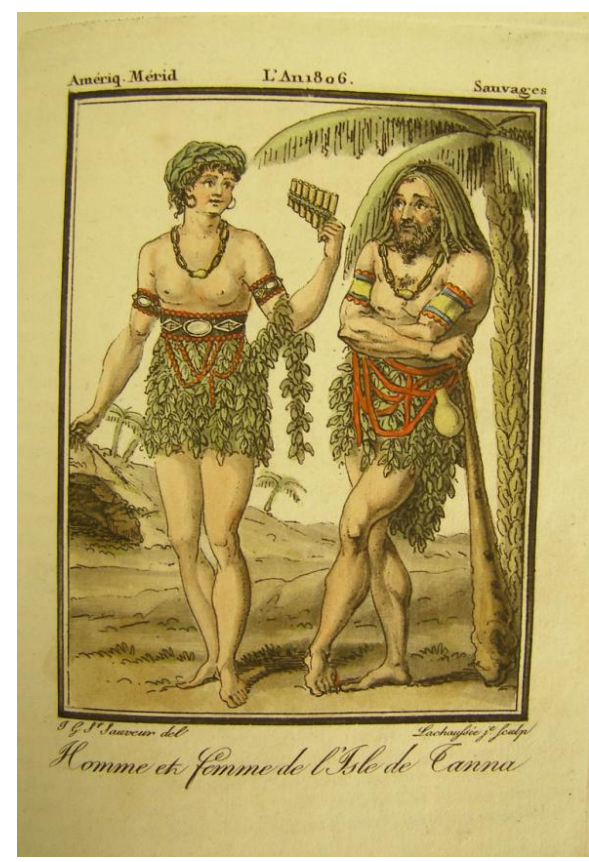

Fig. 28

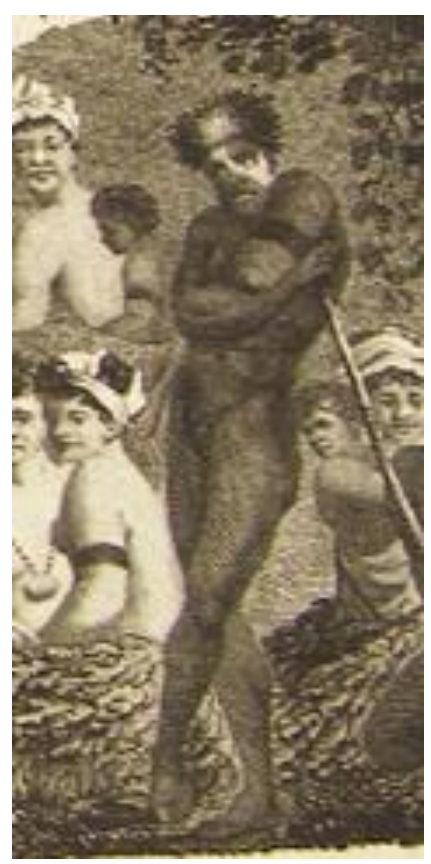

Fig. 29 (detail)

There are some Saint-Sauveur images that have no obvious source in the Cook voyage accounts. For example, while he uses the head of an engraving of Hodges's Man of 
Easter Island (fig. 30) for his own Homme de l'Isle de Paques (Man of Easter Island) (fig. 31), his Femme de l'Isle de Paques (Woman of Easter Island) (fig. 32) bears no resemblance to Hodges's (fig. 33). Whereas Hodges's woman has a conical shaped hat, perforated ears, and is clothed, Saint-Sauveur's woman wears a similar feathered headdress as the man's, has no perforated ears, wears a different kind of necklace and has exposed breasts. Saint-Sauveur's Woman of Easter Island does, however, bear a strong resemblance to an American Indian woman illustrated in one of the English universal geography's particularly in her pose and that of the child, and the basket she is carrying (fig. 34), but he has replaced the child's basket with a club. ${ }^{189}$ Saint-Sauveur also depicts this woman in his 1806 edition as a woman of the Népissens (fig. 35). Interestingly, although she is an American Indian woman, Saint-Sauveur does not add a feather headdress as he does for the Easter Island woman.

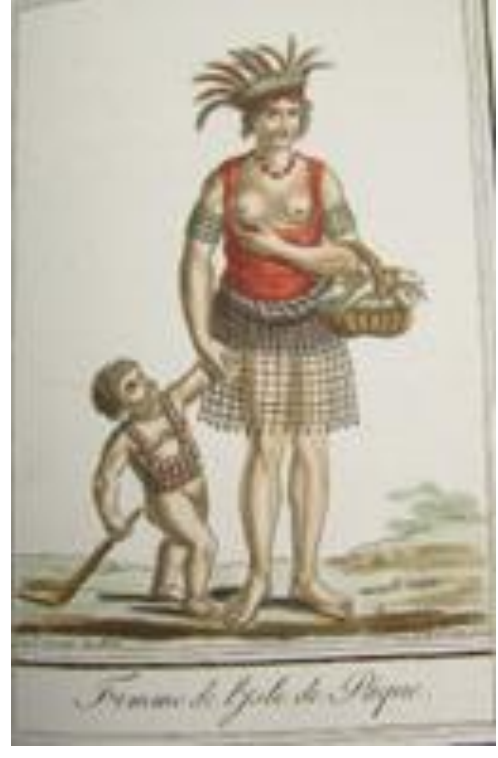

Fig. 32

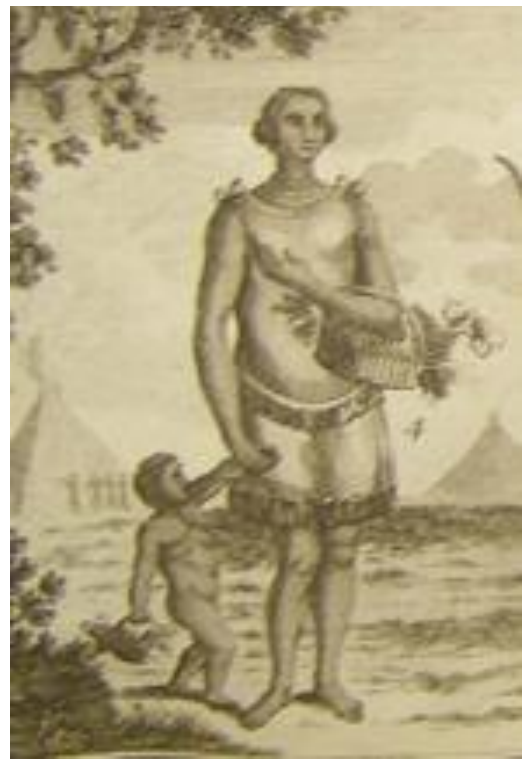

Fig. 34 (detail)

${ }^{189}$ George Millar, The new and universal system of geography: being a complete history and description of the whole world ... London: Alexander Hogg, Paternoster Row, 1782, fp. 793. 


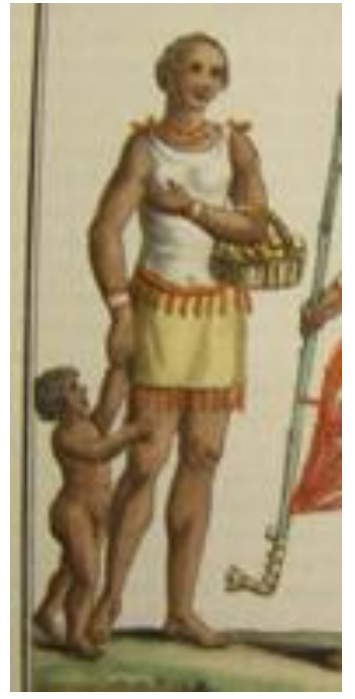

Fig. 35 (detail)

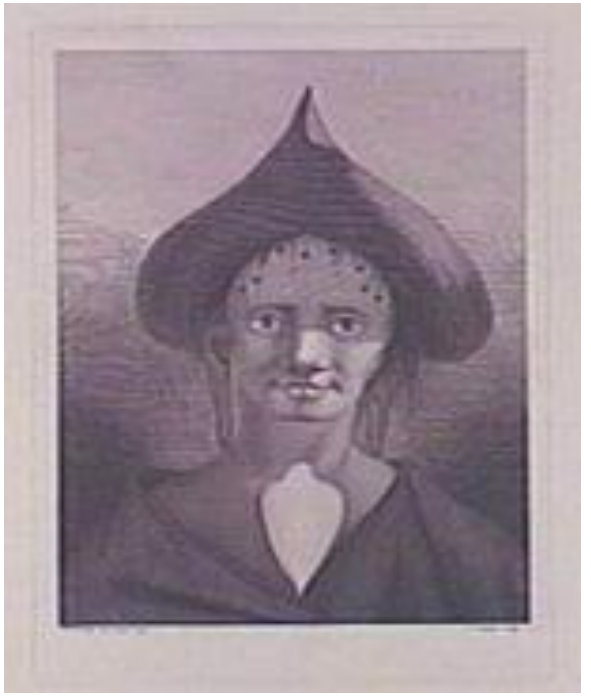

Fig. 33

The heads of his New Zealand men appear to be based on engravings after Parkinson. Hawkesworth's first voyage publication included head-and-shoulder portraits of Māori men, but complete people were only seen in general scenes. The head, necklace and cloak of Saint-Sauveur's Guerrier de la Nouvelle Zelande (Warrior of New Zealand) (fig. 36) is based on the engraving after Parkinson's Head of a New Zealander... (fig. 37).

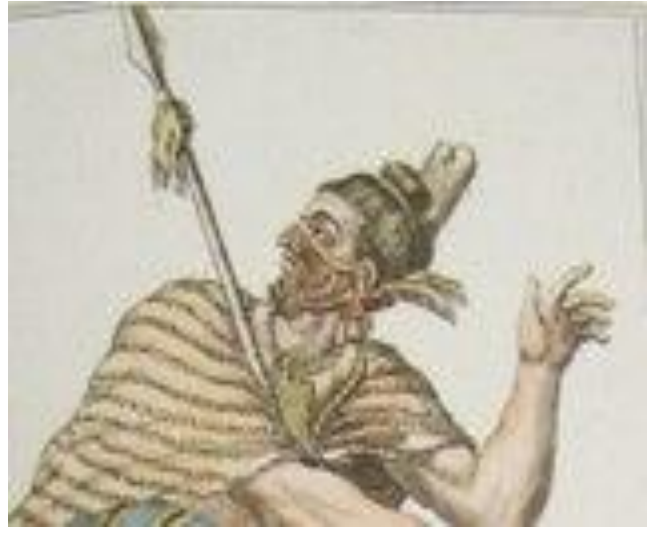

Fig. 36 (detail)

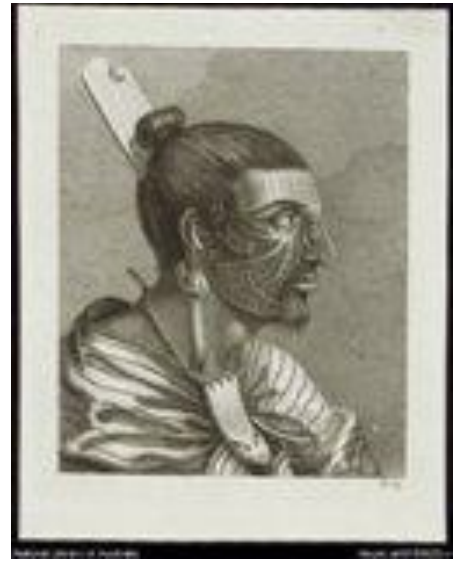

Fig. 37

The head of Saint-Sauveur's Sauvage de la nouvelle Zéelande (Savage of New Zealand) (fig. 38) could have been modelled on one of the Heads of Six Men, Natives of New Zealand, that appeared in Parkinson's Journal. However this would mean that SaintSauveur saw or owned a copy of Parkinson's Journal, and if that were the case it may be wondered why he did not use the distinctive engraving of A New Zealand Warrior in his 
Proper Dress \& Completely Armed to their Manner (fig. 39), as a model for either the Warrior or Savage. In fact, the pose, head, and spear of his New Zealand Savage bear a surprising resemblance to those of the man in Habit of an Antient Britain from Thomas Jefferys English costume book of 1772 (fig. 40). ${ }^{190}$ However, in Saint-Sauveur's 1806 edition, which combined men and women in one image and therefore involved redrawing earlier images, the New Zealand man (fig. 41) does appear to be loosely modelled on the full-length Parkinson New Zealand warrior.

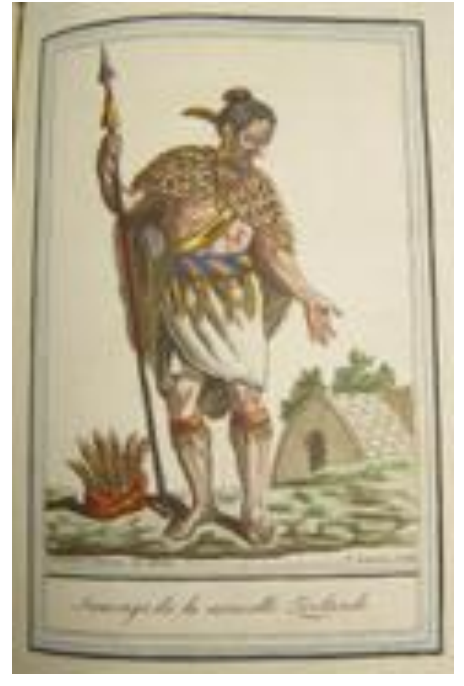

Fig. 38

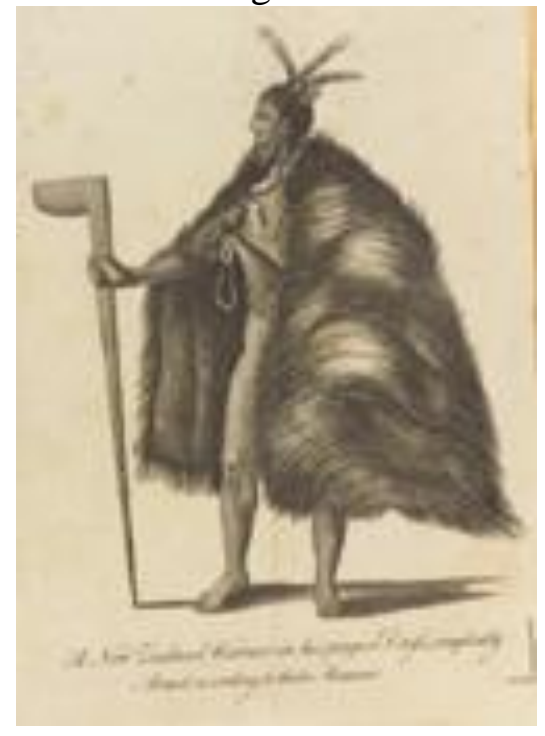

Fig. 39

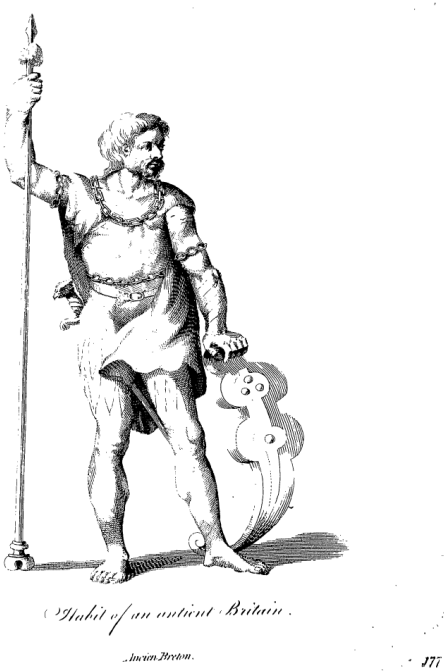

Fig. 40

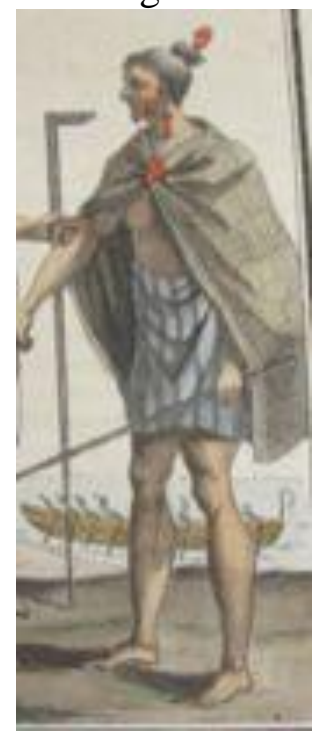

Fig. 41 (detail)

\footnotetext{
${ }^{190}$ A collection of the dresses of different nations, antient and modern. Particularly old English dresses, 4 vols, London: Thomas Jefferys, 1757-72, Eighteenth-century collections online, VUW Library, accessed 20 April 2009. From Gale. Eighteenth Century Collections Online. (C) Gale, a part of Cengage Learning, Inc. Reproduced by permission. www.cengage.com/permissions.
} 
It is interesting to speculate why Saint-Sauveur may have used some illustrations as sources but not others. One possibility is that the editions he relied on did not include all the plates - because of cost, it was quite common at the time for publishers to limit the number of plates, and also, as plates were often sold separately, for some to be incorrectly bound or missing. Assuming he did have complete editions, did he decide that some images were more suitable than others, for example, the man of Easter Island but not the woman? If he had a complete copy of Parkinson's Journal he could have seen an illustration of $A$ New Zealand warrior and his wife in the dress of that country, but the woman does not appear to be a model for either his Sauvagesse de la Nouvelle Zelande (New Zealand woman / 'savagess') (fig. 42) or Fille parée de la nouvelle Zeelande (New Zealand girl) (fig. 43). Again, the second Cook voyage accounts included head-and-shoulder portraits of a New Zealand man and a New Zealand woman after Hodges, but neither appears to have been used as models. There was also the Family in Dusky Bay after Hodges (fig. 44), and in the third voyage account a few Māori people are depicted in Inside of a Hippah in New Zealand after Webber. Although none of these seem to have provided a direct model for any of the New Zealand men or women, they may have given an idea of a New Zealander wearing a cloak and carrying a long spear. It is possible that the standing woman in Family in Dusky Bay provided a general model for Saint-Sauveur's Sauvagesse, although, if so, he has replaced her spear with a baby. This could have been seen as more appropriate to her gender, and, notably, such a change was made to the Family in a mid-1780s English popular account of the voyages. ${ }^{191}$ In calling his Māori woman a sauvagesse he may be reflecting European views which ranked Māori people lower than Tahitians, for example, yet there is nothing particularly savage about his depiction of her - in fact she appears quite maternal. The woman of Pelew (Palau) is also depicted holding a baby - another of his Oceanic 'savagesses'. Most of his other Oceanic women are simply called femme (woman). His New Zealand girl even holds a flower (a rose?) although this seems somewhat incongruous with what appears to be a fish-head that she wears on a necklace. The pose of the New Zealand girl is in fact the same pose (in reverse) as his Femme Tartar Tobolsk (Woman of Russian Tartary; modern-day Russia) (fig. 45).

${ }^{191}$ Discussed by Nicholas Thomas, 'Discovering voyages: researching the Rex Nan Kivell collection', in National Library of Australia, Paradise Possessed: the Rex Nan Kivell collection, Canberra: NLA, 1998, p. 61. 


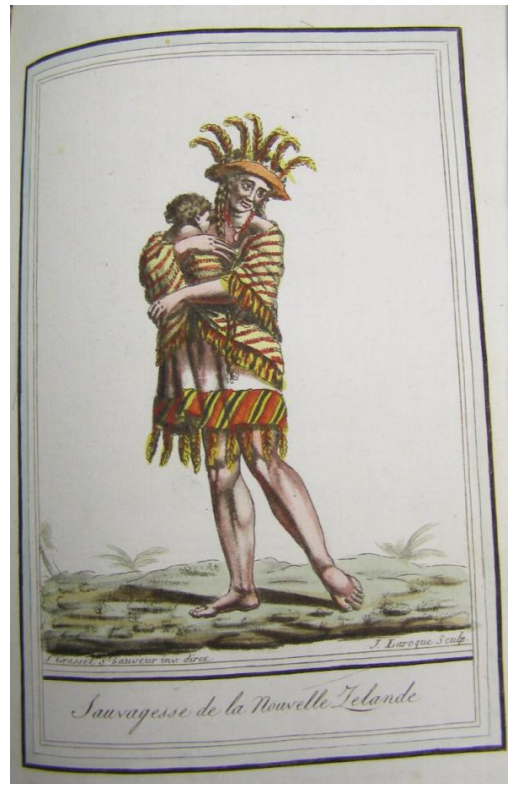

Fig. 42

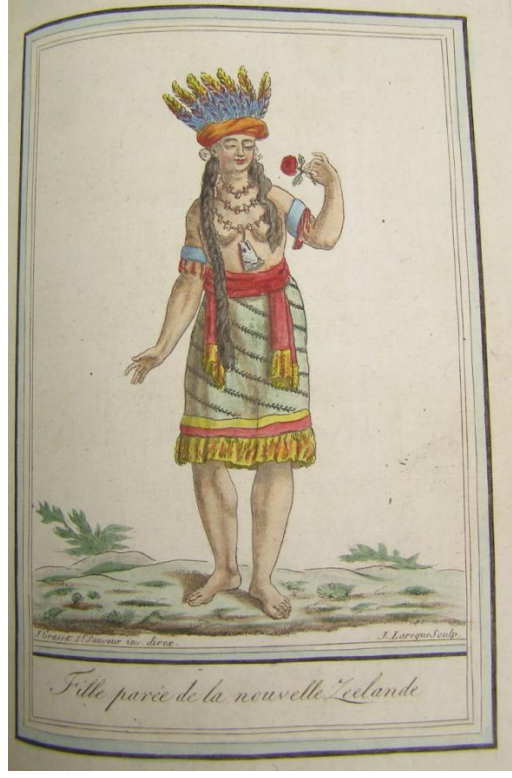

Fig. 43

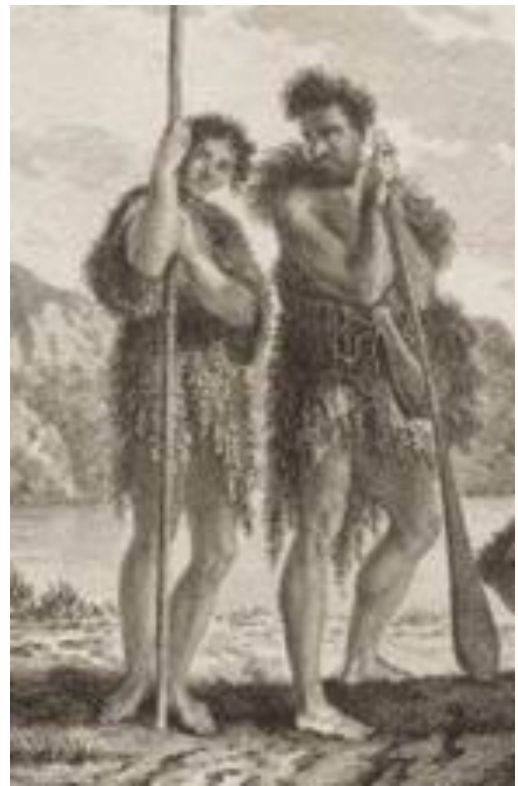

Fig. 44 (detail)

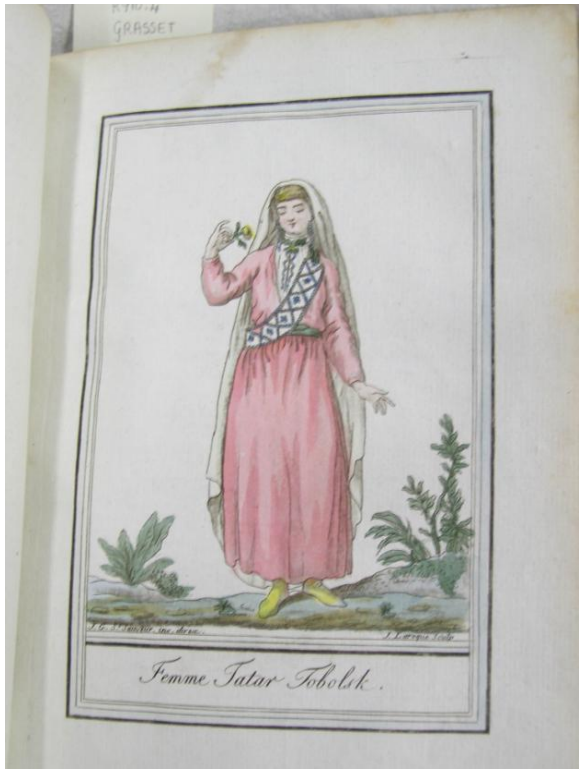

Fig. 45

Did Saint-Sauveur not use the available models of the Easter Island woman and New Zealand women because they did not meet his ideas of the exotic or of 'savagery'? Both his New Zealand girl and woman wear feather headdresses that could have come from an American Indian, whereas neither Parkinson's nor Hodges's Māori women had feathers in their hair. The New Zealand Savage's feather headdress is on the ground. Most of SaintSauveur's people, especially his women, have European faces. Therefore, clothing and 
adornments are needed to distinguish them and it seems likely that he decided that 'savages' were expected to wear feather headdresses. As chapter three showed, a feather headdress was probably the most typical attribute of the personification of America, and the Oceanic peoples were initially added on to America. ${ }^{192}$ As the images were coloured, which added to the cost, it is also likely that he wanted to include colourful objects, such as feathers. For example, the New Zealand Savage's cloak is coloured blue, red and yellow in most editions sighted, but with lighter and darker versions in different copies. It hardly mattered that New Zealand birds are, on the whole, not brightly coloured as accuracy seems to have been of only minor importance. His visual sources were, in any case, black and white engravings. But more importantly, I think, adding features like a feather headdress or a mask where none was in the source image not only made his images more exotic but made them more 'authentic' to their European audience. This is what they expected to see and without them his books may not have been so popular or copied by others.

The late appearance of La Pérouse's voyage account in 1797 (nearly ten years after the ships left France) is likely to have been the catalyst for Saint-Sauveur's Tableau des découvertes du Cap ${ }^{\text {ne }}$ Cook \& de la Pérouse (Tableau of the discoveries of Captain Cook and La Pérouse), 1798/99 (engraved by Antoine Phélippeaux, 1767-c.1830). This was one of a set of five prints - the other four depicting peoples of the four continents - each one accompanied by an explanatory booklet: Tableaux des principaux peuples de l'Europe, de l'Asie, de l'Afrique, de l'Amérique. The Oceanic Tableau consists of peoples from various countries arranged in three horizontal bands, but as if occupying a continuous space (fig. 46). This was a departure from Saint-Sauveur's earlier books, which included single figures or at most a small group of figures representing the various countries separately. He may have got the idea of a tableau from an English book (New discoveries concerning the world and its inhabitants, London 1778, 2 vols). This contains only one image per volume, but the image at the front of volume one is a folded engraving of a tableau of peoples, Persons and dresses of the inhabitants of the South Sea islands (fig. 47). This presents about a dozen different island peoples and animals as if located in one place - a tropical island with European ships in the harbour. As this was published before Cook's third voyage, the figures are sourced from the illustrations to the first and second voyages.

${ }^{192}$ In the 1788 Tahiti text at one point they are called 'Americans of the South Seas' (Américains de la mer du Sud). 
The Oceanic people in Saint-Sauveur's Tableau are sourced from his own earlier books; for example, his New Zealand couple (fig. 48) and Marquesan islands couple (fig. 49). His depiction of some of the peoples encountered on La Pérouse's voyage, for example Manila, Macao, De Langle Bay (on the island of Sakhalin) and De Castries Bay (on the Asian mainland, adjacent to Sakhalin) are sourced from La Pérouse's published account. For example, the three men in the Tableau representing De Langle Bay are adapted from a larger group of French officers and local inhabitants shown in plate 50 of the Atlas $d u$ voyage de La Pérouse, and a couple with baby representing De Castries Bay are also taken from a larger group inside a house shown in plate 54 (part of the house is depicted behind the couple in the Tableau). In both cases, Saint-Sauveur has chosen what appears to be the most prominent man in the group as a 'representative' person.

The popularity of Oceania is also shown by Joseph Dufour (1752-1827) and company's production of a panoramic wallpaper in about 1805: Les sauvages de la mer pacifique, designed by Jean-Gabriel Charvet (1750-1829) (figs. 50-53). This was produced in 20 strips (approximately 10.2 metres width, in total) that could be displayed in different combinations. The prospectus issued with the wallpaper gave some suggested combinations, for example, using five, six or ten strips - thus making it a versatile product for differently sized rooms. This was one of the earliest known panoramic wallpapers - a French speciality, which remained fashionable decorative items for about 60 years. The main distinguishing feature of panoramic or scenic wallpapers is that, unlike other wallpaper, they do not have repeated patterns. They form a continuous scene, or narrative, enveloping a room with the spectator at the centre - each strip or scene is part of a larger whole. Peopled landscapes were the most popular compositions until the 1840s, with the usual subjects being taken from classical mythology or of exotic locations. ${ }^{193}$ Two other panoramic wallpapers produced around the same time by the rival firm of Jean Zuber were Les vues de Suisse (1804) and L'Hindoustan (1807). ${ }^{194}$ The scene began about one metre from the ground so that it was roughly at eye level, and would not be blocked by furniture, and sky occupied a large part of the top so the paper could be cut to fit the height of the room without destroying the scene.

${ }^{193}$ Odile Nouvel-Kammerer, 'Wide horizons: French scenic papers' in Lesley Hoskins (ed), The papered wall: the history, patterns, and techniques of wallpaper, $2^{\text {nd }}$ ed., London: Thames and Hudson, 2005, p. 103.

${ }^{194}$ The designs for L'Hindoustan were sourced from T. and W. Daniell's Oriental scenery and William Hodges's Select views in India (Nouvel-Kammerer, 2005, p. 100). 
Despite, or perhaps because of, wars in Europe at the time, most panoramic wallpapers presented harmonious worlds - conflict, hard work, or erotic scenes were mostly avoided. From the comfort of their sitting or dining room the middle-class man or woman could temporarily forget about the problems outside the door, while admiring the idyllic exotic scene. As it was on display in their home, it also needed to say something about their taste to friends and visitors. At the beginning of the prospectus, Dufour stated that:

This decoration has been designed with the object of showing to the public the peoples encountered by the most recent explorers, and of using new comparisons to reveal the natural bonds of taste and enjoyment that exist between all men, whether they live in a state of civilisation or are at the outset of the use of their natural intelligence. ${ }^{195}$

He then suggested how particular groups would find it of interest, for example, how it might appeal to women, including that a mother might use it to give effortless lessons to her eager, inquisitive and intelligent daughter. He clearly anticipated that women would have a role in choosing it as a decoration, and it was designed to appeal to both sexes. In addition to brief summaries of each country in the prospectus, he suggests that to fully appreciate it one should read the explorers' accounts, and helpfully makes volume and page references to the multi-volume summary of voyages by Jean-Francois de la Harpe (Abrégé de l'histoire générale des voyages, Paris, 1780-86). So, the wallpaper can be seen as an illustrated encyclopaedia or costume book on a large scale. The landscape setting is supposedly Tahiti, but various peoples encountered mostly by Cook are depicted. Cook's death in Hawaii is shown in the background of strip eight, as is the volcanic island of Tanna in the New Hebrides (Vanuatu). Dufour anticipated some criticism for juxtaposing different places and events, but appealed to the artistic licence taken in the "interest of the success of the design". Taking elements out of their natural context and 'recontextualising' them contributes to the exoticism of the work.

Panoramic wallpapers were expensive to produce and therefore manufacturers chose scenes that could be expected to be popular. The wallpaper depicted peoples encountered on English voyages - mainly Cook's three voyages - rather than additional ones from La Pérouse or d'Entrecasteaux's voyages, which could support the idea that

\footnotetext{
195 Prospectus translation in AGNSW/NGA, 2000, p. 32. All quotations from the prospectus are from this source.
} 
Dufour may have had an American market in mind when he commissioned the wallpaper design. ${ }^{196}$ The Pelew (Palau) islanders in strip 20 are sourced from the account of Captain Wilson, shipwrecked on the island in 1783; Saint-Sauveur's books and his Tableau had also included Pelew islanders. Panoramic wallpaper designs were usually sourced from existing prints rather than being original, as this might give some guarantee of popularity.

Charvet appears to have used Saint-Sauveur's books or his Tableau as one of his main sources, which is an indicator of the popularity of these works. For example, the New Zealanders (in strips 10 and 11) are represented by a seated warrior with his back to the viewer; a woman and child, and a war party of four men walking through the forest in single file (fig. 54). The design for the New Zealand woman combines elements from SaintSauveur's Girl of New Zealand (see fig 42, and inset below) - the clothing, armbands and necklace in particular; although the feather headdress and direction of her gaze is more like that of Saint-Sauveur's Woman of New Zealand (see fig. 42 ). ${ }^{197}$ The child's pose is similar to that of the child with the Easter Island Woman, which as mentioned was probably sourced from an American Indian woman (see fig. 34) but it is a pose that also appears in an image of A divorce ceremony practised by the Canadians. ${ }^{198}$

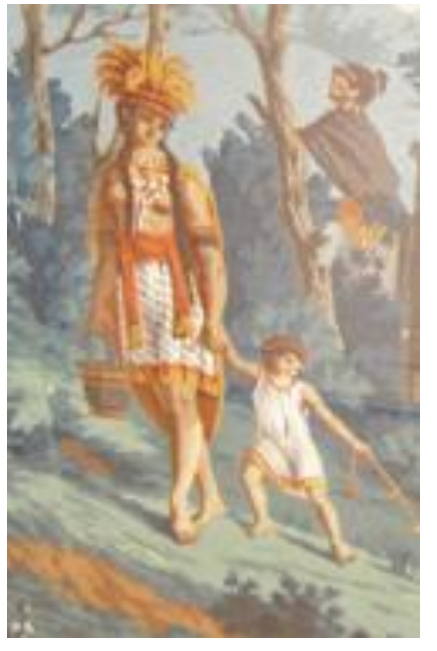

Fig. 54 (detail)

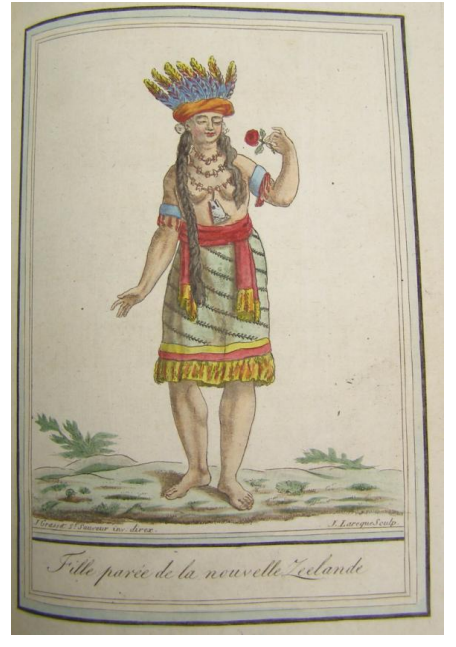

Fig. 43

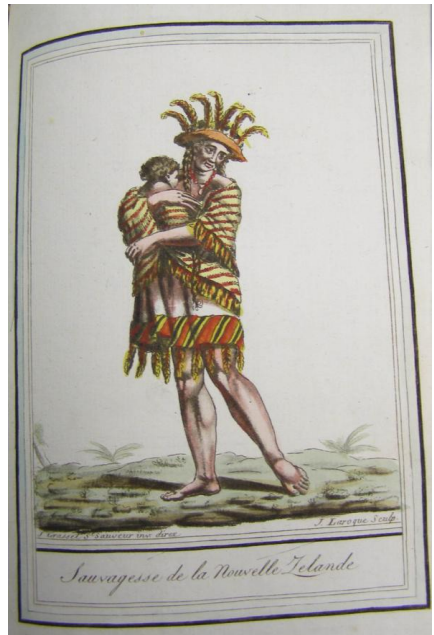

Fig. 42

\footnotetext{
${ }^{196}$ AGNSW/NGA, p. 16.

${ }^{197}$ Roger Collins mentions this, and also notes the pose of the NZ warrior is probably based on Saint-Sauveur, but in a reversed position ('An inside story: Dufour \& Charvet's wallpaper of the South Seas' Bulletin of New Zealand Art History, 9, 1985, p. 10.) Rüdiger Joppien (1979, p. 202) also mentions Grasset de SaintSauveur's influence, in particular on the woman of New Caledonia.

${ }^{198}$ In Bernard Picart The ceremonies and religious customs of the various nations of the known world, London 1733-39, vol. 3, translated from French, Eighteenth Century Collections Online, VUW Library, accessed 1 July 2009. This image is also reproduced in other English books later in the century. The French edition was popular and no doubt known by Saint-Sauveur.
} 
Some other figures in the wallpaper are also adapted from Saint-Sauveur, for example, the man and woman of Tanna in strip 7 have similar costumes and accessories including the woman's panpipes and the man's club - as Saint-Sauveur's man and woman of Tanna (see fig. 28); and the pose and clothing of the king of Tahiti are also similar to Saint-Sauveur's king. The wallpaper's Marquesan islanders in strip 18 have different poses, but the same clothing and accessories as Saint-Sauveur's Marquesan man and woman. Saint-Sauveur's Sauvage des Isles Marquises (Savage of the Marquesas Islands) is depicted in an aggressive posture, carrying a slingshot and knife (fig. 55), whereas in accord with the peaceful theme of the wallpaper, the Marquesan man appears to talk to the woman, but he still carries a knife and slingshot (fig. 56). ${ }^{199}$ Despite the prospectus saying that the Marquesan men are heavily tattooed and wear large plates of wood in their ears, neither Saint-Sauveur's nor the wallpaper's Marquesan men have either of these decorations. In relation to the inhabitants of New Caledonia, the prospectus says they wear large items of jewellery in their ears and noses, but "we have permitted ourselves to suppress the absurd parts of a picture which is only intended to offer pleasant objects to the eyes of the public". 200

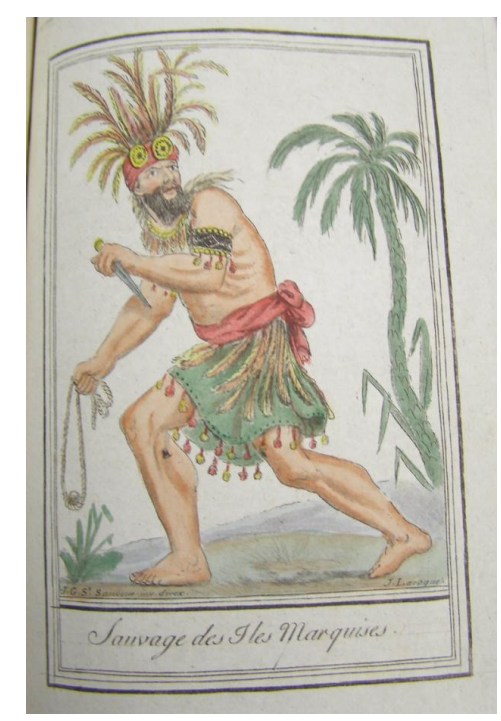

Fig 55

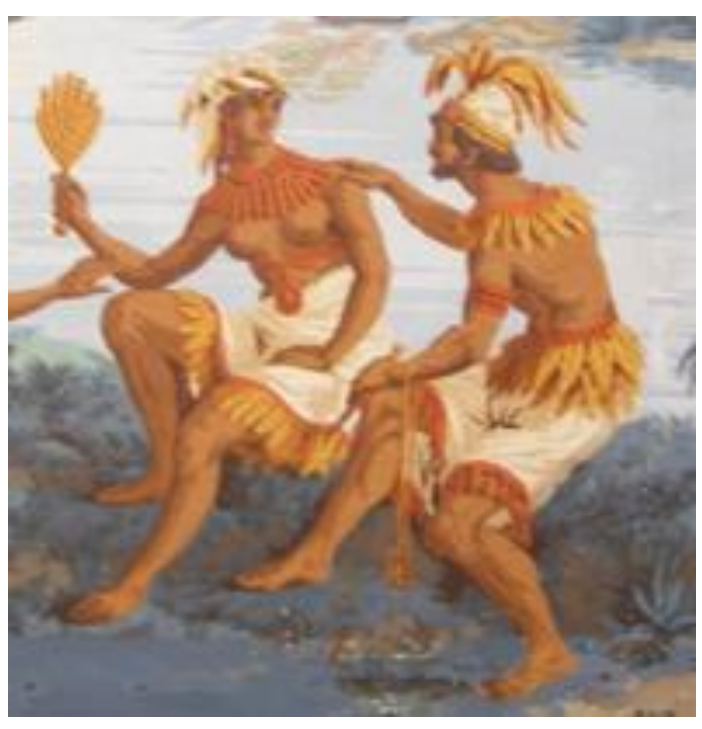

Fig 56 (detail)

\footnotetext{
${ }^{199}$ I have not identified a specific source for Saint-Sauveur's Marquesan man - except that his headdress is likely to be based on an engraving after Hodges. The Cook voyagers found the Marquesans peaceful people, on the whole, and Saint-Sauveur himself says this in his text. It is probably an image that pre-dates the Cook voyages. The Spanish 'discovery' of the Marquesas in 1595 involved much bloodshed and they mentioned encountering weapons such as the sling-shot.

${ }^{200}$ AGNSW/ NGA, p. 38
} 
One of the prominent elements in the wallpaper is three Tahitian women dancing (in strip 5) in a landscape setting, with musicians and spectators surrounding them (fig. 57). The prospectus explains that the dancer on the right of the group is "Poyadua, daughter of Oreo, chief of the district" and she is dressed in a taama "a sort of corset which is used out of prudence or necessity as a breast guard". ${ }^{201}$ Some dancers in engravings after John Webber wear this type of 'breast-guard' (see fig. 18). Saint-Sauveur's books included a Tahitian 'danseuse' (female dancer) (see figs. 17 and 20), although only the 1788 edition showed her with the 'breast-guards'. But the three Tahitian dancers depicted in the wallpaper are not directly from this source. It is likely a number of sources were used - the composition of three dancers, musicians on the left and audience on the right is similar to Cipriani's dance scene (see fig. 19) and John Rickman's anonymously published journal, Journal of Captain Cook's last voyage to the Pacific Ocean, 1781, included a group of dancing women in Representation of the Heiva at Otaheite (drawn by Daniel Dodd; fig. 58). However, the costumes in the wallpaper are a more fanciful depiction than either of these and, although one includes a vestige of the tapa cloth around the waist that was in the Webber illustration, they may have more closely resembled costumes from French ballet or theatre. The Cipriani scene includes three women dancing, but three may also allude to the Three Graces of Greek mythology - Banks, Bougainville and Commerson all compared Tahiti to ancient Greece - Commerson praising the beauty of the women and calling them "the sisters of the Graces ... the lightest veil floats away with the wind and the desires."202 The group of musicians playing for them are likely to have been sourced from those in the Cipriani View (see fig. 19, and below) - with the addition of colourful headwear and extra figures. This image was reproduced, in reverse, in the popular French collection of voyages by De La Harpe; a series that was referred to in the prospectus accompanying the wallpaper.

\footnotetext{
${ }^{201}$ Dances by Oreo's daughter Poyadua were witnessed by Cook and others on the second voyage, on 26 and 29 May 1774. The same woman was depicted as Poedua by John Webber on the third voyage. Anne Salmond spells these names Poiatua, daughter of Reo. She describes the dancers' dresses as comprising bodices of brown bark cloth, with red and white bark cloth ruffles around their waists, layered with bark cloth petticoats. The 'turbans' on their heads were made of coiled plaited hair decorated with white feathers. (See fig 18). Salmond, pp. 216-217.

${ }^{202}$ Commerson, in Mercure de France: "les sœurs des Graces sans voile...la plus légère des gazes flotte toujours au gré du vent et des désirs."
} 


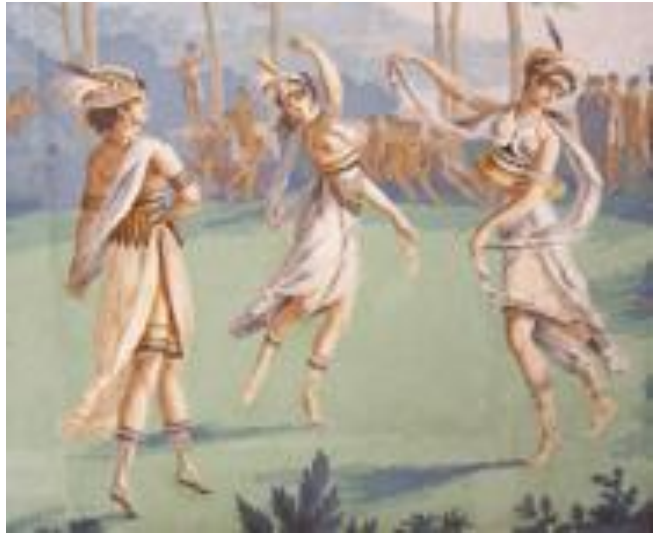

Fig. 57 (detail)

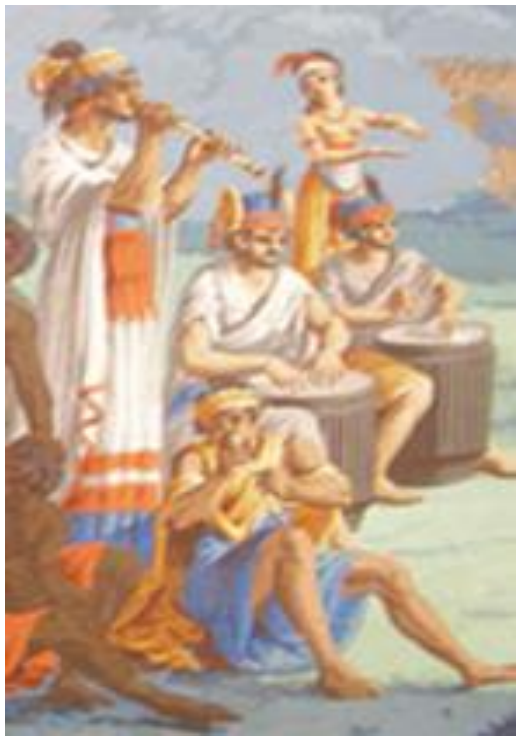

Fig. 57 (detail)

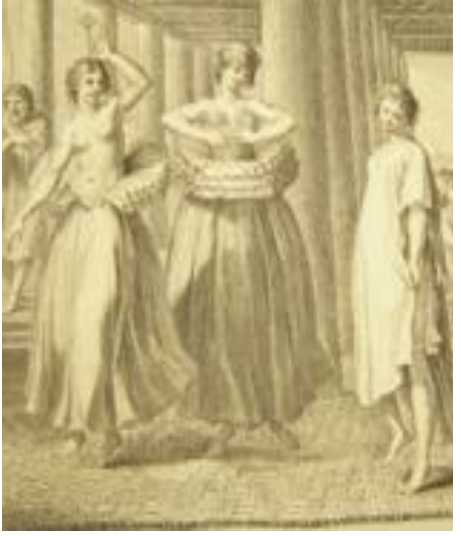

Fig. 19 (detail)

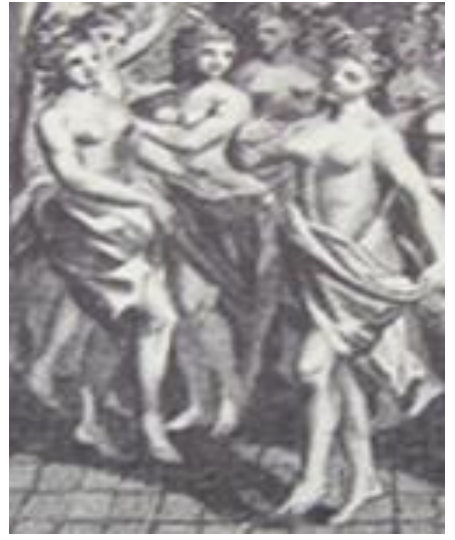

Fig. 58 (detail)

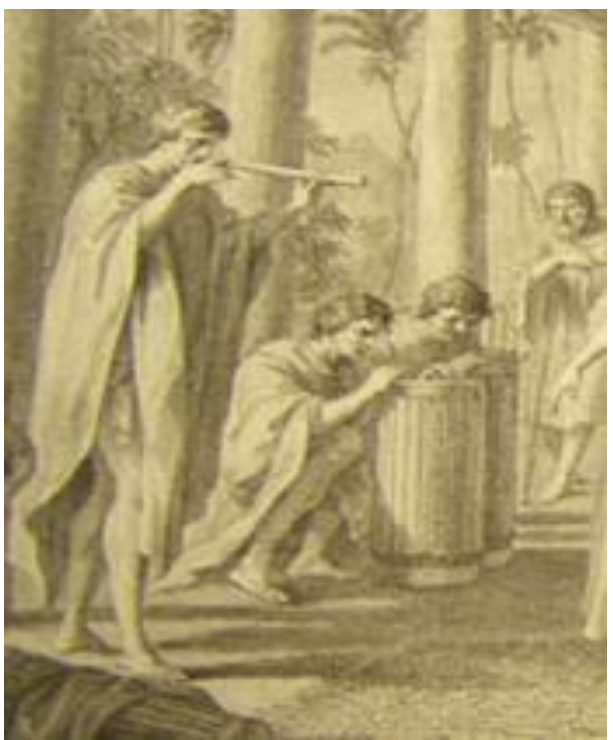

Fig. 19 (detail)

Saint-Sauveur's Tahitian girl and Tahitian man have no particular characteristics that identify them as Tahitian - they could equally be illustrations of ancient Romans or Greeks. They are also sourced from this image invented by Cipriani after drawings by Parkinson (see fig. 19) - the girl being the fully clothed dancer to the right of the main poles of the house and the man being the man standing on the right (figs. 59 and 60). SaintSauveur may have deliberately chosen these two to agree with the often expressed comparison of Tahiti with ancient Greece and, in his text accompanying Tahiti, he says that one may observe, perhaps with surprise, the manner of wearing clothes is similar to the 
Roman ${ }^{203}$ Nevertheless, he is also critical of the philosophers' views, accusing them of praising the islanders too highly and slandering the Europeans too much, adding that the islanders have faults, such as being slaves to their priests, practising infanticide and other crimes. ${ }^{204}$

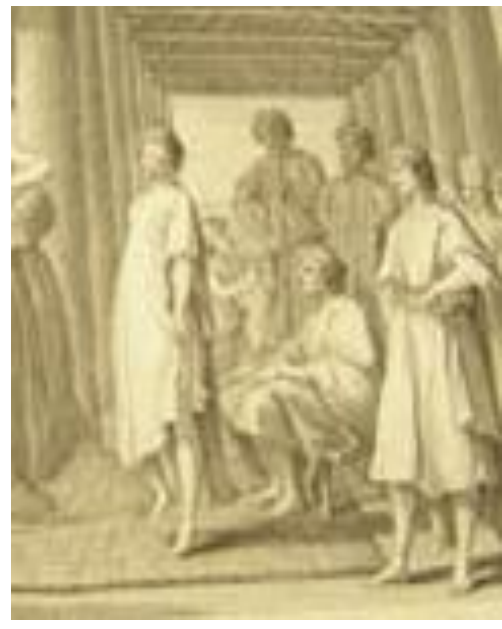

Fig. 19 (detail)

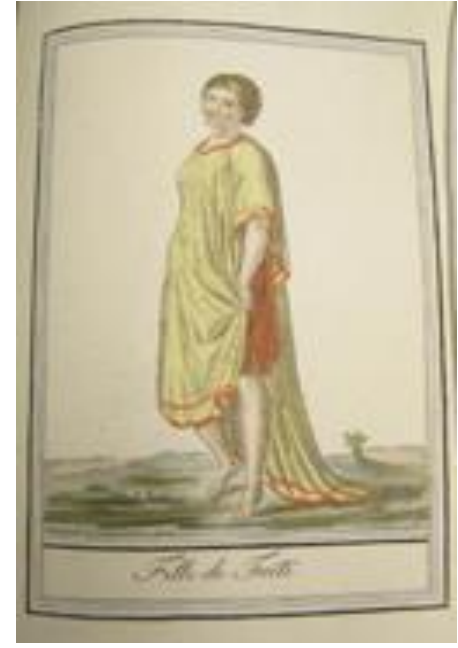

Fig. 59

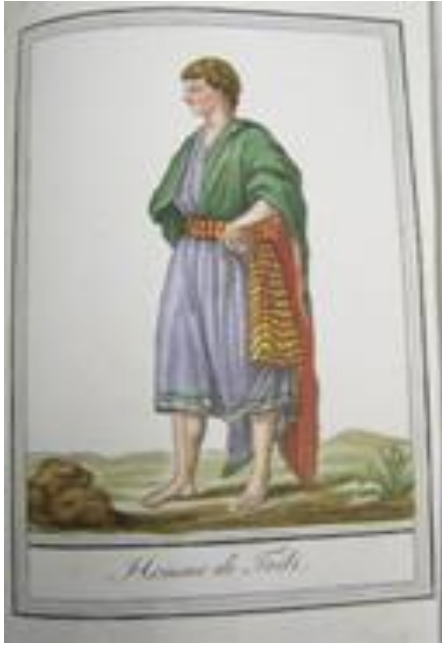

Fig. 60

In the 1788 edition there is no girl of Tahiti, only a woman and man of Tahiti. While Saint-Sauveur's girl and man could be seen as classicising images, the 1788 woman and man (by Desrais?) seem to embody a 'noble savage' type of classicising (figs. 61 and 62). Neither of these images is based on Saint-Sauveur's Tahiti images nor appears to be based on the art of Cook's voyages. If anything, the Tahitian man's head resembles SaintSauveur's head of the New Zealand savage, while his pose is that of the Apollo Belvedere.

\footnotetext{
${ }^{203}$ Saint-Sauveur, Tahiti 1784, p.5: "On remarquera peut-être avec étonnement dans la manière la plus généralement usitée de porter ces étoffes, de grands rapports avec l'habit romain."

${ }^{204}$ Saint-Sauveur, Tahiti 1784, p. 2: "Les philosophes, les ennemis des découvertes et des colonies, ont sur ce point comme sur tant d'autres, trop loué les Insulaires, et trop calomnié les Européens. Ce peuple, dont ils vantent le bonheur et l'innocence avant l'arrivée des voyageurs, étoit esclave de ses prêtres, divisoit tous les citoyens en plusieurs classes, avoit des chefs et des princes, immoloit ses enfans sur les autels de ses divinités; connoissoit les arts, le commerce, la navigation, la guerre, la jalousie, tous les crimes..."
} 


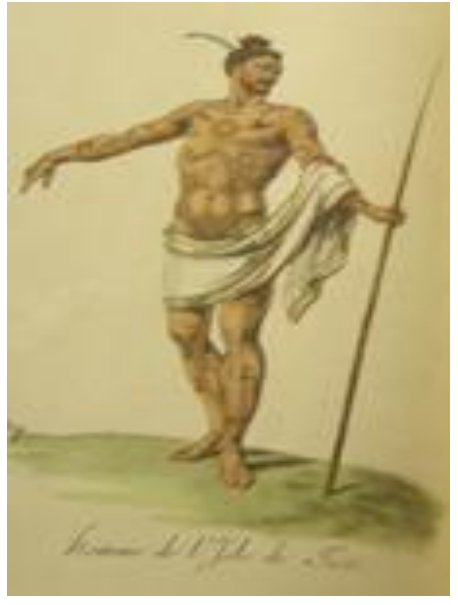

Fig. 62

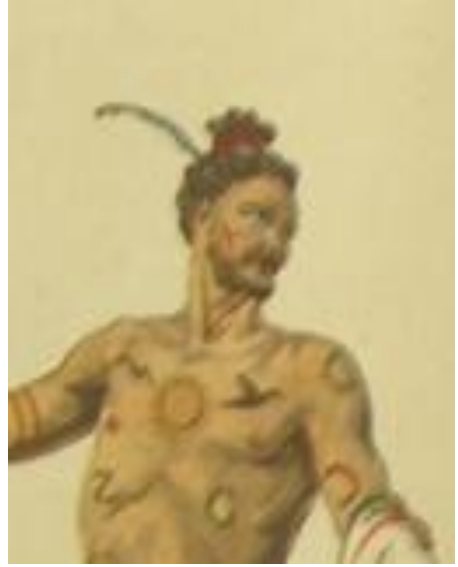

Fig. 62 (detail)

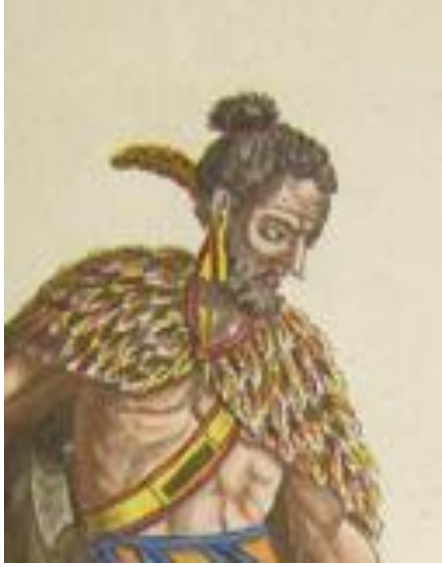

Fig 38 (detail)

Exotic places and peoples helped Europeans to compare their society with others, but descriptions of exotic places tended to highlight what to Europeans was unusual or 'bizarre' - a word that is used several times in the 1788 Tahitian text (although in the wallpaper some 'oddities' are suppressed so as not to upset the viewer). Both Desrais's 1788 Tahiti man and woman clearly show tattoos. Ancient Britons and Picts (fig. 63) were also often depicted with tattoos or body paint, which was another point of comparison between Oceanic peoples and those of an earlier stage of European development. Nicholas Thomas has noted (in relation to islanders tattooing) that the tattoos are spectacular, and "in a way, they positively invite decontextualization". ${ }^{205}$ Yet, Saint-Sauveur only occasionally includes them - is he deliberately suppressing 'oddities' or is it just that he is more interested in clothes and adornments than faces and bodies? Sometimes, however, it is difficult to tell if he is depicting a tattoo or an arm- or leg-band. His texts often mention tattooing, such as in New Zealand, the Marquesas and Tahiti. In fact, Desrais may have designed the 1788 Tahitian man and woman to illustrate another part of the text:

The use of tattooing, which seems to be common to all the islands of the South Seas ... exists above all in Tahiti ... Almost everyone has a $\mathrm{Z}$ on each toe or finger; the arms and legs are covered in crude figures of men or animals; flowers, the moon, the sun are painted on the buttocks ... ${ }^{206}$

\footnotetext{
${ }^{205}$ Nicholas Thomas, 'Introduction' in Nicholas Thomas, Anna Cole \& Bronwen Douglas (eds), Tattoo: bodies, art and exchange in the Pacific and the West, London: Reaktion Books, 2005, p. 9.

${ }^{206}$ Tahiti 1784, p. 4: "L'usage de se tatouer, qui semble être commun à tous les Insulaires de la mer du Sud.. existe sur-tout à Otahiti...Presque tous portent un $\mathrm{Z}$ sur chaque doigt du pied ou de la main; les bras et les jambes sont couverts de figures grossières d'hommes et d'animaux; les fleurs, la lune, le soleil sont peints sur les fesses..."
} 
However, this is from Saint-Sauveur's 1784 text, and although the 1788 text that Desrais's illustrations accompanied said the Tahitians were often nude, it did not specifically mention tattooing. It compared the rouge that European women wore on their cheeks with the blue 'make-up' (fard) the Tahitians of both sexes wore on their buttocks. ${ }^{207}$ The text of the 1788 edition is credited to Sylvain Maréchal and he is less skeptical of the views of 'philosophers' than Saint-Sauveur in his 1784 edition.

Few of the books in this study mention any sources for their images. While the sources for Oceanic images can mainly be found in the Cook voyage art, it is more difficult to trace sources for the other images. However, some other sources can be found by looking at other costume books that do acknowledge their sources, such as the English one published by Thomas Jefferys between 1757 and 1772 and the 1802-1807 Dutch costume book of Martinus Stuart (text) and Jacques Kuypers (illustrations). ${ }^{208}$ While travellers accounts were their main sources, Jefferys also relied on Joseph-Marie Vien's Caravanne for over 20 dresses of Turkish nobles, which, as he says, is "a book which represents the Dresses in a Turkish Masquerade given by the Pensioners of the French Academy in Rome, in the Year 1748". ${ }^{209}$ In turn, Thomas Bankes's Universal Geography (1790) illustrates some of the same Turkish costumes sourced from Jefferys or Vien. Stuart and Kuypers footnote their sources, which include comments on Saint-Sauveur's books in a number of places (e.g. for New Caledonia: Saint-Sauveur, "who was only acquainted with the journeys of the first travellers, depicts angels in a paradise". ${ }^{210}$ ) This is another indication of the popularity of Saint-Sauveur's books as most of their other references are to travellers' accounts or histories. Books showing various occupations of urban dwellers were another popular source - for example, Jean-Baptiste Le Prince's Première suite de cris et divers marchands de Petersbourg et de Moscou, 1765, provided both Jefferys and Saint-Sauveur with images - Saint-Sauveur depicts various merchants and servants for St Petersburg and Moscow; showing that where he has a full-body source he is likely to use it.

${ }^{207}$ Tahiti, 1788 p.4 "Mais, que diront nos Européens si fières du rouge dont elles se peignent les joues, quand elles sçauront que les Taitiennes sont usage aussi d'un fard bleu, qu'elles placent sur leurs fesses."

${ }^{208}$ Martinus Stuart and Jacques Kuypers, De mensch, zoo als hij voorkomt op den bekenden aardbol, Amsterdam: Johannes Allart, 1802-1807 6 vols, ATL.

209 'A description of the habits of Turkey' in A collection of the dresses of different nations, antient and modern. Particularly old English dresses, London: Thomas Jefferys, 1757-72, Eighteenth Century Collections Online, VUW Library, accessed 4 September 2008 and 20 April 2009, vol. 1, 1757, p. 1.

${ }^{210}$ St Sauveur "de reizen van den eersten alleen kennende, schildert er Engelen in een paradijs" - Stuart and Kuypers, 1802, vol. 1, p. 196-7. 
Clearly, for Saint-Sauveur, neither physiognomy nor ethnographic accuracy was important - the people are, on the whole, just display mannequins for clothing and adornments. So what was important? He emphasised that his books were both to inform and entertain. He used examples of clothing that were unusual to a European audience, such as the Tahitian girl carrying a present, the Sandwich Island dancer and the Tahitian king. But at other times he chose from a source with nothing particularly unusual such as the Tahitian girl and man, except perhaps to emphasise the comparison of Tahiti with classical Greece and Rome. He combined elements from various sources, as well as occasionally using American Indians as sources for Oceanic people. I believe he did omit 'oddities' particularly for women, for example the perforated ears of Hodges's Easter Island woman would have appeared unfeminine to a European at that time and he probably did not want to show 'ugly' images. He added adornments where he may have felt they were lacking in the original source and where a European reader would expect to see them, such as feather headdresses, to make a more exotic, but at the same time, 'authentic', image. Finally, their colouring completed the exotic image, but one that was nevertheless pleasing to the eye. Having invented a cast of Oceanic peoples, the next chapter will look at the illustrated encyclopaedias as a whole to see how they integrated them into the wider world. 


\section{Chapter 5 - Costume and custom in illustrated encyclopaedias}

In traversing these tableaux, an instant is enough to get an idea of all the people who compose the universe: in an instant, one has a clear idea of the varieties of the human species who, for a lifetime, are immediately engraved on the memory; their aspects, their names, their classes; one recognises their costumes and their characteristic traits. $^{211}$

... by contrasting the manners of savage and civilized nations together, the student insensibly benefits by the bright side of the comparison. ${ }^{212}$

The previous chapter considered the sources for the representations of the Oceanic peoples in Saint-Sauveur's costume books, which were mainly derived from Cook's three voyages, but fashioned to suit European taste and the costume book genre. The English universal geographies were not discussed in chapter 4 as their Oceanic images are, on the whole, fairly faithful reproductions of published voyage illustrations. But how do the Oceanic images fit in the context of the books? The information available on Oceania was recent compared to that of many other countries - does this make a difference in presentation? Do the text and images 'tell' the same stories? Does the illustrated book format impose a certain uniformity on the images? This chapter argues that all the images conform to certain pictorial conventions that allowed Oceanic peoples to be easily incorporated into the books. The representations of a range of countries will be considered, covering each continent, to see how other places and peoples compared to the Oceanic islands. Local clothing was a main identifier of a region and its customs and occupations; but the clothing was not always accurate. The chapter will also consider images of dancing as one widespread 'custom' - there is a relatively high proportion of images of people dancing in both French and English books - but, although dancing was common everywhere, the books show only non-Europeans or, rarely, country-dwelling Europeans dancing. Was this to show evidence of "savage freedom" (as Bernard Smith says) or simply to add variety and entertaining images? The illustrated encyclopaedias continue earlier

\footnotetext{
${ }^{211}$ Jacques Grasset de Saint-Sauveur, introduction to vol. 1, 1806. "En parcourant ces tableaux, un instant suffit pour prendre une idée de tous les hommes qui composent cet univers: en un instant, on a une idée lumineuse des variétés de l'espèce humaine qui, pour toute la vie, se grave aussitôt dans la mémoire, à leur aspect, on les nomme, on les classe, on les reconnaît au costume et à ces traits caractéristiques."

${ }^{212}$ Charles Middleton, A new and complete system of geography ... 2 vols, London: J Cooke, 1777, ATL, preface to vol. 1, unpaginated.
} 
traditions - the 'South Sea' islands were just the most recent exotic locations presented to appeal to public curiosity and imagination. The books reveal a fairly superficial interest, at a popular level, in other peoples: one that is mainly interested in contrasting 'civilised' Europe with less civilised or 'savage' others.

In Saint-Sauveur's costume books, the pictorial conventions include an emphasis on clothing rather than physiognomy, so the people are depicted full length and their faces are usually non-descriptive. The background is also usually rudimentary or schematic. The representations are of generic types to represent a particular area, or occupation of an area. In Saint-Sauveur's earlier editions it is more common to depict single figures, although there are examples of two people together. In his 1806 edition almost all places have only one image which includes two people, usually but not always male-female couples. There is always a caption, and in the 1796 and 1806 editions each image has a border and the names of the illustrators are included (earlier editions did not always include these). The images in the English books have a more elaborate border with the author's name and brief title of the book engraved at the top of each image (such as "Engraved for Middleton's Complete System of Geography") and also include a caption, but less frequently the artists' names. When they depict typical costumes, they usually depict groups of people rather than a single person and tend to include more background than Saint-Sauveur's images. The French prints are hand-coloured etching and aquatints, whereas the English engravings are not coloured.

Before I examine in detail representations of other countries, the pictorial conventions, as well as other ideas I will develop, can be seen in a comparison from SaintSauveur's 1806 edition of a French couple (Habitans de Paris, fig. 64) and the New Zealand couple depicted in fig. 41 (inset below for ease of comparison). The words at the top of the images are, for the Parisians: Europe; L'An 1806; Emp. Francais; and for the New Zealanders: Ameriq. Merid.; L'An 1806; Sauvages [Savages]. These indicate which continent they are located in (Oceania considered part of Southern America), the date, and political status of the country. As New Zealand at that time was not ruled by a single ruler such as a king, or a European power, they are listed as 'savages' (in common with many other non-European places). Both images have the same artists - Saint-Sauveur as 'del' (designer) and Lachausée jeune (the younger) as 'sculp' or etcher. 


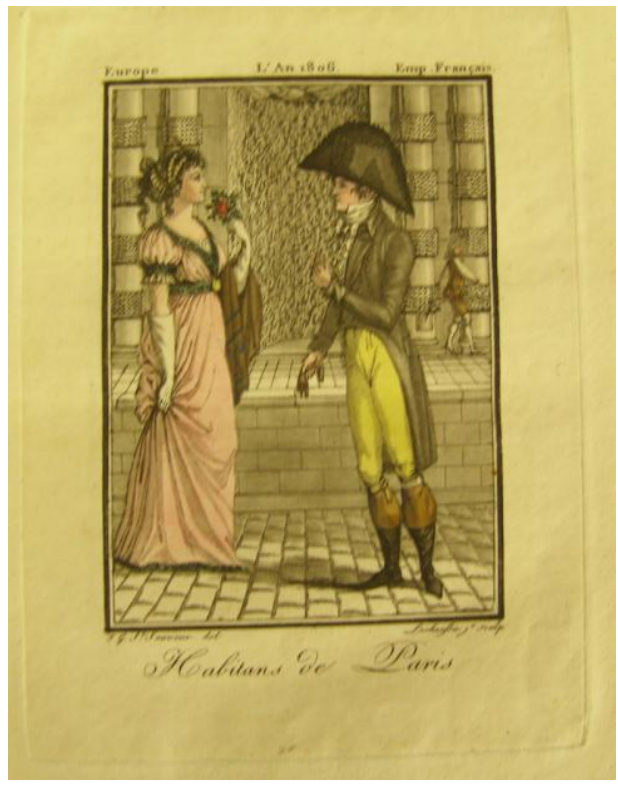

Fig. 64

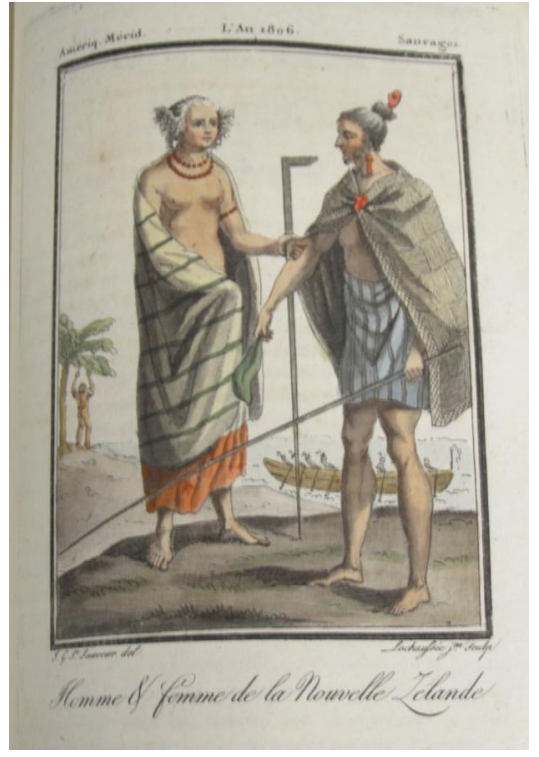

Fig. 41

The placement of the couples is similar, with the man on the right and woman on the left. The Parisian couple are elegantly dressed in the Empire fashion of the time, while the New Zealand couple are also well dressed for 'savages' - perhaps because the man is, I believe, loosely based on the engraving of Parkinson's Māori chief (as mentioned in chapter 4). They both have 'accessories' that are meant to help identify them - the Parisian couple: flowers, gloves, hat and shawl; the New Zealand couple: a spear (or fishing rod?) and a staff, and both wear cloaks. Where the French man carries gloves, the New Zealand man carries something that might have been based on the greenstone mere that Parkinson's Māori chief had, but in Saint-Sauveur's depiction it looks more like a large leaf. The Parisian image has more background - a paved street, building and a fountain, as well as a small figure of a working class man carrying something over his shoulders. The New Zealand background is more schematic, but the fact New Zealand is an island is shown by water and a canoe. The working man in the background of the Parisian couple is echoed by a man reaching up to the palm tree, who is probably representing the idea that 'savages' did not have to work for their food - a common European assumption was that it was simply there for the picking. This comparison shows how relatively easy it was to fit the 'new' Oceanic peoples into existing conventions.

As well as the difference in background, clothing is the obvious distinction between 'civilised' and 'savage'. This distinction appeared in the earliest costume books in the 
sixteenth century where clothing was a symbol of differences between peoples; as Olive Dickason argues: "the widest gap being between the totally naked Amerindian and the elaborately dressed European". ${ }^{213}$ The European's dress signified rank, authority and civility, whereas the American Indian's nakedness indicated the state of nature and a perceived lack of social order. ${ }^{214}$ For Europeans, clothes were the visible signs of social standing and the theme of mistaken identity because of clothing was a common one in novels and plays. ${ }^{215}$ French-influenced dress became popular during the eighteenth-century for the wealthier classes throughout Europe; fashions being disseminated by fashion magazines, prints, and fashion dolls circulated around the capitals of Europe. However, regional styles were common, especially among the poorer classes, but also sometimes with the wealthier in areas with long traditions of individual style, such as Strasbourg. ${ }^{216}$ Accessories were also an important part of dress and etiquette, as well as demonstrating wealth, taste and in advancing courtship. ${ }^{217}$

Beginning my analysis of the continents with Europe (especially France and England, which were for each country the measure of civilisation), in his costume book of 1796 Saint-Sauveur includes a representation of a French man and woman titled Francais et Francaises (fig. 65) after the preliminary discourse and just before Paris, and therefore as a generic French man and woman. To represent Paris he actually has a peasant couple from the environs of Paris (fig. 66), a clear contrast to his well dressed Francais et Francaises. Similarly for England, which comes at the beginning of Volume 2, preceding the text he represents a couple called Anglais et Anglaise (used here in place of a frontispiece, fig. 67) and an image of three English peasants is included after the text on London. ${ }^{218}$ In the 1806 edition, he replaces the generic French and English couples with representations of Parisians and Londoners. His Parisians include the fashionably dressed 'inhabitants' Habitans de Paris discussed above (see fig. 64), and two images of people representing various occupations. London is represented by a Bourgeois and Bourgeoise de Londres

\footnotetext{
213 Dickason, p. 50.

214 ibid.

${ }^{215}$ Eileen Ribiero, Dress in eighteenth-century Europe, New Haven \& London: Yale University Press, 2002, p. 168.

216 ibid., p. 94.

217 ibid., p. 159.

218 The artists for these two 1796 images are Labrousse 'del' (designer) and Saint-Sauveur 'direx' (directed), showing that Saint-Sauveur had various collaborators.
} 
(fig. 68) and by a peasant couple. There is not much difference between the French and English couples in the 1796 edition, both being placed in a schematic "anywhere" type of landscape, but the Parisian couple in 1806 are dressed more elegantly and fashionably than the equivalent London couple, although both are clearly city dwellers. In contrast, the Parisian peasant woman has a large basket of vegetables on her back and wears wooden clogs, compared to the dainty shoes of his Paris and London bourgeoises, thus clearly showing class differences. In his 1796 London text he says the fashions of the English (although copied from the French) need the "hand of taste to be placed with advantage" implying of course that the English do not have it. ${ }^{219}$ Perhaps not surprisingly, the English books describe the French as subject to the "caprices of fashion"; but they are even more condemnatory about their supposed superficiality, the effeminacy of the men, and the great freedoms of the women. ${ }^{220}$

Many of Saint-Sauveur's European images (and those of the French colonies of Saint-Domingue and Martinique) show people engaged in various occupations, for example, Artisannes of Marseille and Arles (fig. 69); a couple disputing over oysters (Poissarde de Bordeaux disputant avec un m' d'huîtres de la tête de Buch) (fig. 70) and servants of Strasbourg (fig. 71) one of whom carries bowls on her head. Unlike the Europeans, most peoples of other parts of the world are not shown doing anything in particular - the main exceptions are dancing, and fighting (or armed for war or hunting). Even when the text mentions the people are skilled at some craft, this is not depicted. There are a few images of prêtre médecin ('medicine men') or some religious ceremony, slave dealing (in Senegal), and preparing a dye from a plant (rocou) in Guyana, where the two men are nearly naked and the building is in a dilapidated state (fig. 72). Of the nonEuropean representations, only those of the Chinese and Arabs include images of sellers of goods or food (for example, fig. $\mathbf{7 3}$ shows a Chinese mobile food seller, with holes in his clothing). The Europeans are clearly better dressed, even the working classes, and the overall message is one of industrious, civilised Europe compared with the rest of the world, many of whom are nearly naked or poorly dressed, and shown as superstitious, mostly

\footnotetext{
${ }^{219}$ Saint-Sauveur: "La manie des modes a corrompu les mœurs anglaises. Depuis quatre années, les coëffures et les chapeaux que les femmes portent à Londres, sont d'une bisarrerie choquante. On ne fait pas assez attention, que ce qui sied sur les rives de la Seine, peut devenir maussade sur les bords de la Tamise. Tous ces ajustemens frais et légers, exigent la main du goût, pour être placés avec avantage." Londres, 1796, p. 2. ${ }^{220}$ For example, Middleton, pp. 352-353.
} 
indolent, or warlike. The English books do not include many images of Europe, especially not of people - there are some views of cities, ports, and activities specific to particular places, such as a Spanish bullfight. However, the overall impression is still one of 'civilisation' (Europe) versus ‘barbarity or savagery' elsewhere. Among the typical nonEuropean images they depict are assassinations (e.g. in Persia), methods of torture and execution (in parts of Asia) and methods of fighting (e.g. in Africa).

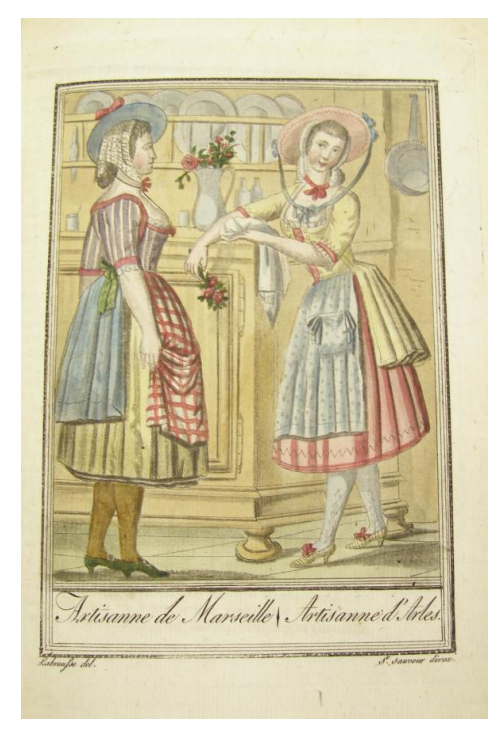

Fig 69

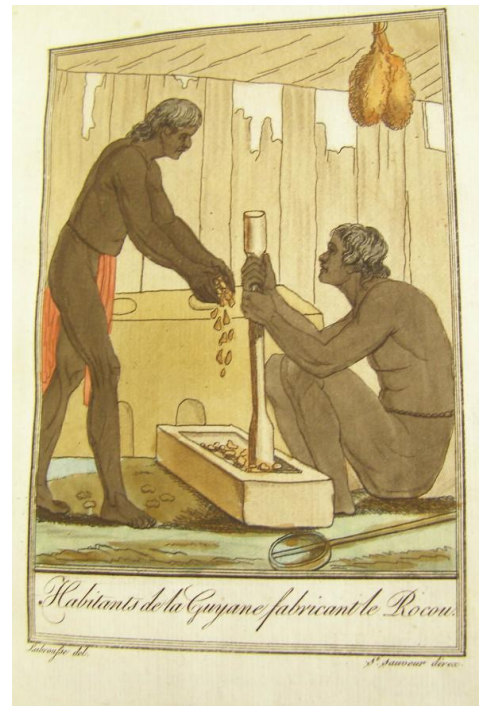

Fig 72

As discussed in Chapter 1, the 'exotic' could be surprisingly close to home. SaintSauveur included three illustrations in his 1796 edition of shepherds on stilts and one in the 1806 edition of a tenant farmer (metayer) and shepherd (berger) on stilts (fig. 74). This was a local custom of the 'Landes of Bordeaux' (a rural area south of Bordeaux) - as Graham Robb explains:

The shepherds of the Landes spent whole days on stilts, using a stick to form a tripod when they wanted to rest. Perched ten feet in the air, they knitted woollen garments and scanned the horizon for stray sheep ... They could cover up to seventy-five miles a day at $8 \mathrm{mph}$... It was such an efficient mode of transport that letters in the Landes were still being delivered by postmen on stilts in the 1930s. ${ }^{221}$

Saint-Sauveur says of the Landais that they are not "very civil" - their way of life makes them "rural and wild", they are inclined to avarice and drunkenness (particularly after festivities and dances) and their huts are badly built and even more badly furnished. He has

${ }^{221}$ Robb, p. 243 
only three sentences about the men on stilts but their strangeness obviously appeals when it comes to illustrating the area ("they make use of stilts ... the agility with which these people go thus perched on stilts is astonishing; a trotting horse cannot follow them"). ${ }^{222}$ Their rather shabby clothes, bare feet and sheepskin cloaks would have contributed to the impression of wild people with unusual customs. However, although 'rustic', they are still shown working - something few non-Europeans are shown as - and they are not exotic in the way Mason uses the term - in that they are not taken out of their context - they are depicted with their sheep, dog, and landscape.

Turkey was included with Europe in Saint-Sauveur's books, whereas the English books usually divide it into European and Asian sections. It provides a useful transition point between Europe and Asia as it was considered by the French and English to have some 'civilising' characteristics, but also in some ways typifies their views of Asia generally, as subject to despotic government, with superstitious, indolent, amusementloving people. In the Ottoman Empire dress was important as an indicator of identity (especially religious) and to help the government regulate and control life. ${ }^{223}$ An elaborate dress code was enforced - consisting mainly of a kaftan (loose-fitting neck-to-toe garment with long sleeves) - colours, materials and accessories (head- and foot-wear in particular) were all controlled. Turbans and yellow slippers were restricted to Muslims. The sultan and court nobles sometimes wore as many as three kaftans so contrasting materials and colours could be displayed. ${ }^{224}$ Embroidery was one of the principal occupations of the women and Saint-Sauveur includes an image of Turkish women sewing "at their tanndour" (fig. 75). ${ }^{225}$ Robes were awarded by the sultan for particular offices and also to foreign ambassadors. Most European merchants and travellers wore local costume as it suited the climate and was expected..$^{226}$ The catastrophic defeat of the Ottoman Empire against Russia in 1768-74

\footnotetext{
222 'Les Landais sont peu civilés; le genre de vie qu'ils mènent, les rend agrestes et sauvages: ils habitent dans des cabanes isolées, mal construites, et encore plus mal meublées... Ils se servent d'échasses, et il n'est pas rare de voir des bergers élevés de terre de la hauteur de 4 et 5 pieds. L'agilité avec laquelle ces gens marchent, ainsi juchés sur des échalas, est étonnante ; un cheval, au trot, ne peut les suivre. Ils portent toujours un long bâton dont ils ne se servent que pour les aider à franchir des fossés qui ont quelquefois 20 pieds de large." Landes de Bordeaux, 1796, pp. 1 \& 5.

${ }^{223}$ Philip Mansel, Dressed to rule: royal and court costume from Louis XIV to Elizabeth II, New Haven \& London: Yale University Press, 2005, p. 38.

${ }^{224}$ ibid., p.39.

${ }^{225}$ This, he explains, was a table with a carpet over it falling to the floor, under which a pot of embers was put. Those sitting at the table could thus keep warm.

${ }^{226}$ Mansel, p. 41.
} 
was reflected in the ambassadors receiving a sable cloak (sable previously being reserved for the sultan, at least in theory). The Ottoman Empire continued to enforce sumptuary laws into the late eighteenth century, as Mansel says - "as if strict enforcement of dress rules could counteract economic and military decline". ${ }^{227}$

The clothing of the Ottoman Empire was a favourite subject for travellers and artists to depict. One of the most popular sources was a collection of 100 prints of costumes of the Levant, first published in 1713 (Recueil de cent estampes représentant différentes nations $d u$ Levant). Commissioned by the Marquis de Ferriol (the French ambassador to Constantinople) they were engraved from small paintings by Jean-Baptiste Vanmour. Perrin Stein says that despite the popularity of the collection it contained little that was innovative and "despite the view that his scenes were realistic, they reveal many debts to earlier pictorial traditions and preconceived notions of the East played a role too".228 Jefferys's English costume book acknowledges “M. de Ferriol” as his source for a number of his Turkish images, and it is most likely that Saint-Sauveur also used the collection or intermediate sources copied from it.

Saint-Sauveur included eleven images and twelve pages of text on Turkey in his 1796 edition - more than most other countries received. Turkish subjects (turquerie) were very popular in eighteenth-century France and England; not only actual people or objects from the Ottoman Empire, but also Europeans dressing à la turque. In her survey of French eighteenth-century interest in turquerie Perrin Stein relates the changes over the century to changes in French society rather than any specific events relating to Turkey itself. ${ }^{229}$ SaintSauveur even depicts two European women dressed as Turks - the only time he depicts anyone in the clothing of another country (fig. 76) - thus showing a fairly common subject in French painting and at masquerades. However, as many of his women have Europeantype faces it is only the title that distinguishes these women as Europeans. The illustrations accompanying Turkey in the 1796 edition include what Europeans would have expected to see - as well as 'typical' costumes, images included a female slave, a female dancer, women sewing, women enjoying a meal, women praying, women at the baths, and dervishes. In fact, of the eleven images only two show men (the dervishes and one simply

\footnotetext{
${ }^{227}$ ibid., p. 42

${ }^{228}$ Stein, 1997, p. 60.

${ }^{229}$ ibid., p. 273.
} 
called Musulmans). Rebecca Joubin analysed the French Encyclopédie entries on the near east - of an estimated 3,400 entries (c. 500 on Iran; c. 600 on the Ottoman Empire and Turkey) 186 dealt with women and "tell tales of power, ambition, seduction, and betrayal" or expose the dangerous effects of women's power. ${ }^{230}$ About two pages of Saint-Sauveur's text is on women and their role in society (he says their destiny is "passive and precarious"231). Bankes says the Turkish women "lead a life of pleasure, exempt from cares. Their whole time is spent in visiting, bathing, or the agreeable amusement of spending money, and inventing new methods of adorning their persons". ${ }^{232}$ Saint-Sauveur notes the clothing of the men and women is almost alike, except for the headwear where men wear turbans, and both English and French books note the clothing of the classes does not differ much either, except the richer women have more jewellery. Saint-Sauveur says the costume in Turkey is not prone to the whims of fashion. ${ }^{233}$ As noted in chapter 4 , Bankes included several Turkish costumes that were sourced from either Jefferys's costume book or from Jefferys's source, which was Joseph-Marie Vien's Caravanne published in 1749. As Perrin Stein notes, "a common fallacy of exoticism was the belief that the Orient was not subject to the passage of time, that beyond the European capitals, fashion was forever static". 234

Saint-Sauveur is particularly scathing about the dervishes (fig. 77) and similar sects - "these insects of superstition who pullulate in the dust of ignorance would undoubtedly disappear with the first rays of state education". ${ }^{235}$ Joubin, in her analysis of the Encyclopédie articles on Islam, argues they denigrated Islam in terms that could be seen as a subtle way of attacking Christianity; and they were positive about Arabic science to exalt the role of science and reason as opposed to religious revelation. ${ }^{236}$ Saint-Sauveur would appear to have shared similar views on the supposed rational benefits of education and

\footnotetext{
${ }^{230}$ Rebecca Joubin, 'Islam and Arabs through the eyes of the Encyclopédie: the "other" as a case of French cultural self-criticism' International journal of Middle East studies, 32, 2000, p. 198.

231 "La destinée des femmes y est donc absolument passive et précaire: et telles sont les mœurs que nécessite le despotisme." Turquie, 1796, p. 3

${ }^{232}$ Bankes et al, p. 196.

233 "Le costume en Turquie n'est point sujet aux caprices des modes." Turquie, 1796, p. 10.

234 Stein, p. 204.

235 "Ces insectes de la superstition, qui pullulent dans la poussière de l'ignorance, disparoitroient sans doute, aux premiers rayons de l'instruction publique, dirigée par le gouvernement." Turquie, 1796, p. 5.

236 Joubin, pp. 206-207.
} 
superstition of religion. For Turkey, Saint-Sauveur's images and text are generally in accord, although his depiction of the dervishes does not match the virulence of his text.

The Kamtschatka peninsula is in Siberia facing Alaska and was visited by Captain Cook on his third voyage. The people are either called Kamtschatkas or Kamtschadales. They and their customs are generally described as barbaric or savage. Saint-Sauveur, for example, says the people "who live in this horrible climate are almost as wild as the animals of which they are surrounded", but he does credit them with some talents, such as for building sledges, and note some changes under Russian influence. ${ }^{237}$ Bankes says they are "exceedingly slovenly, neglecting to wash themselves". He says their dress consists of animal skins, although noting that some of the women's clothing is "gay and pleasing", 238 which comes from the Cook voyage account. Images from Cook's third voyage were not available for either the English costume book published by Jefferys or for Middleton's Universal Geography. Jefferys states his source for these people's clothing was L'Abbe Chappe D'Auteroche, and Middleton may have used the same sources (or possibly used Jefferys) (fig. 78 - dress of the women of Kamtschatka).

Saint-Sauveur and Bankes made use of engravings from Cook's third voyage, which were based on John Webber's Kamtschatka drawings. Saint-Sauveur's Kamtschatka man (fig. 79) is taken from a larger image based on Webber, called The inside of a winter habitation, but which Bankes calls The summer habitations of the superior people of Kamtschatka (fig. 80). Saint-Sauveur's Kamtschatka woman (fig. 81), may have been loosely based on the woman sitting on the right of this image, although her outfit also appears reminiscent of a Russian or European peasant woman's. It is likely he based the head and shoulders on another engraving after Webber and added a dress to resemble a Russian woman's. The Cook account noted that the women followed the Russian fashion. Saint-Sauveur's Kamtschadale woman (fig. 82) may have come from the same source as Middleton and Jefferys used - particularly the 'tassels' on her dress and the fact she carries a basket (compare with fig. 78). However Saint-Sauveur's woman, especially with her turban-like headwear, looks more Russian or 'Oriental' and more elegantly dressed than the

\footnotetext{
237 "L'homme qui habite cet horrible climat est presque aussi sauvage que les animaux dont il est entouré... L'habillement des Kamtschadales a subi de grands changemens depuis que les Russes se sont établis parmi eux ... C'est dans leurs traîneaux que l'on remarque le plus d'adresse et d'imagination." Kamtschatka, 1796, pp. 1, 2, 5.

${ }^{238}$ Bankes, p. 117.
} 
Kamtschatka people shown in other sources. His Kamtschadale man is difficult to source as he does not much resemble any after Webber or any of the four illustrated in Jefferys, except that he carries a similar spear to one of Jefferys's men. His clothing may be more of an invention, perhaps to resemble a Russian outfit. Nevertheless, none of Saint-Sauveur's four images conveys a people "almost as wild as their animals" as he says in his text. Although the Kamtschadale man carries some weapons, the overall impression of the four images is generally no different than many of Saint-Sauveur's Europeans or some other Asian peoples.

Until the end of the eighteenth century the relationship between Europe and Africa was mostly commercial, in particular Africa was a source of raw materials, including slaves - as European names for parts of Africa attest: Gold Coast, Ivory Coast, Grain Coast. Ezio Bassani and Letizia Tedeschi trace the image of the Hottentot from the seventeenth to early nineteenth centuries, noting that many of the images are similar and used the same sources. ${ }^{239}$ Sources were in general agreement that the Hottentot men wore a girdle of animal skin and the woman an 'apron', in wet weather they wore a mantle of sheepskin; both sexes wore jewellery of leather, glass, bone or shells, and women wore leather rings around their shins. ${ }^{240}$ Another 'tribe' of Hottentots, called Namaquas, are also illustrated in Saint-Sauveur's books - according to both Saint-Sauveur's text and the English books these people are more "polished" or "a little more civilised than the others". ${ }^{241}$ However, Saint-Sauveur's illustrations of a Negre Namaquas (fig. 83) and Negresse Namaquas (fig. 84) are closer to the dress of the Hottentots illustrated and described by Bassani and Tedeschi, and shown in the illustration of Hottentot men, women and children in Middleton (fig. 85). Saint-Sauveur's Hottentot (fig. 86) appears to wear shin-length pants, and although his Hottentote (Hottentot woman) (fig. 87) does wear the shin rings and animal skin mantle described above, she also wears a feather headdress not described or illustrated by anyone else (other sources depict a cap or no head-wear). His Hottentot man is depicted with an aggressive facial expression and pose, which generally accords with his description

${ }^{239}$ Ezio Bassani and Letizia Tedeschi, 'The image of the Hottentot in the seventeenth and eighteenth centuries', Journal of the history of collections, 2(2), pp. 157-186.

240 ibid., p. 173.

241 “Quelques voyageurs ont cru voir dans les Namaquas une peuplade absolument distincte des Hottentots; mais ces sauvages...sont de véritables Hottentots, un peu plus civilisés que les autres.” Hottentots, 1806, p. 6. 
of them as depraved and ignorant, ${ }^{242}$ and his description of the weapons they use in hunting or war. However, as with all the illustrations in Saint-Sauveur's 1806 edition, the man and woman are depicted together and, although he carries a spear, he is no longer in an aggressive pose (fig 88). There is some agreement between text and images of the Hottentots and Namaquas, but he adds some fanciful elements such as the pants and the ubiquitous feather headdress.

While the Hottentots are described as 'depraved and ignorant' a few customs receive more positive comment, such as their system of justice; ${ }^{243}$ however another African people (Anzikos and Jaggas) are presented entirely negatively by both Saint-Sauveur and the English books. They are (supposedly) cannibals having markets of human flesh; they live by plunder and war, and according to Saint-Sauveur "can pass for the most barbarian nation of the universe". ${ }^{244}$ In accord with these descriptions, both Millar and Middleton illustrate their manner of fighting - using large shields that can protect their backs if in retreat (fig. 89). Saint-Sauveur's Negre Anzikos armé en guerre also shows an armed warrior, with a small vignette of human butchery in the background (fig. 90). Nevertheless, he also illustrates a Homme et femme de qualité le Jaggas, which presents a different image from the text (fig. 91). The man, in particular, has a rather 'noble' bearing - and presents an obvious contrast to a number of Saint-Sauveur's other Africans, for example, the man from the Grain Coast (Côte des Graines) who is poorly dressed and looks like he lacks intelligence (fig. 92).

242 "S'il existe sur la terre un peuple qui, par la bassesse de ses inclinations, la stupide ignorance et la dépravation de son caractère ... c'est assurément l'Hottentot ... Le caractère de ce peuple est aussi repoussant que son aspect; le repos et l'ivresse sont ses uniques plaisirs." Hottentots, 1806, pp. $1 \& 2$.

243 "La paix, la guerre, la justice civile et criminelle, tout dépend de cette assemblée; le coupable est placé dans le centre; tous les assistans inclinés autour de lui écoutent tranquillement sa défense; ensuite un cri général le condamne ou l'absout, et le capitaine du Kraal est l'exécuteur du jugement, qui ne déshonore pas la famille: faut-il que nous ayons pendant tant de siècles méconnu une vérité à laquelle les plus vils sauvages ont rendu hommage." Hottentots, 1806, p. 5.

244 "Ils se nourrissent d'ailleurs de chair humaine, et sont antropophages. Leurs armes sont le dard et la dague. Ils s'adonnent aux sortilèges, et ils peuvent passer pour la nation la plus barbare de l'Univers." Les Anzikos et les Jaggas, 1806, p. 2. 


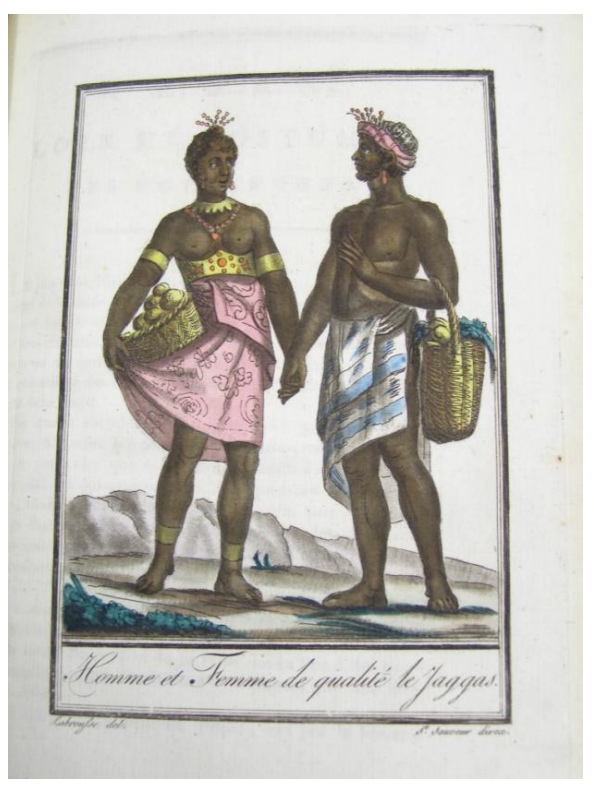

Fig. 91

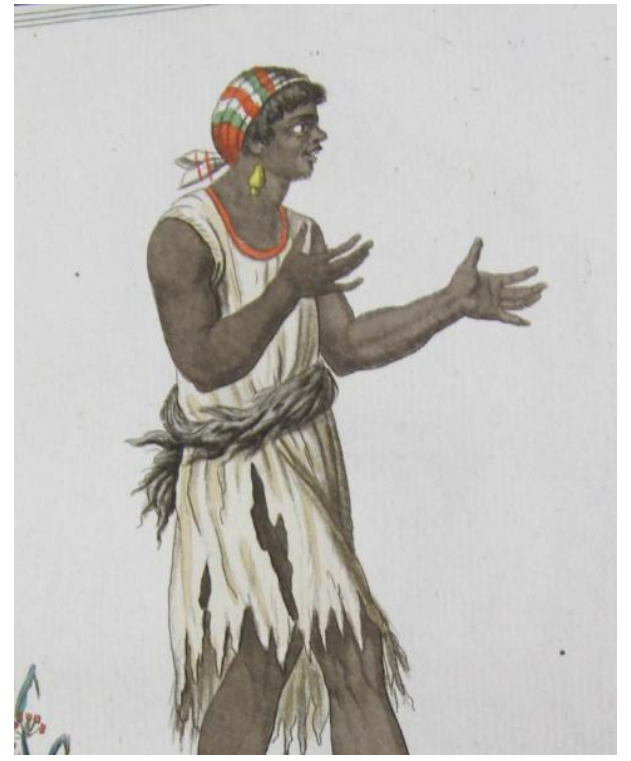

Fig. 92 (detail)

Apart from their colour, this image of the 'Jaggas of quality' does not match his description of the people as "extremely black and deformed". 245 The couple both carry a basket of fruit or vegetables - despite the text saying "they do not plant, sow or maintain herds; they draw their subsistence only from their plunders", this may represent the fruit of palm trees, which he says they collect - "being impassioned for the wine, and the fruit of these trees". ${ }^{246}$ Nevertheless there is nothing in this image to suggest the "most barbarian nation in the universe" and they differ little from some of his other depictions of 'savages'. He may here be showing a common class bias of the time in expecting those of 'quality' or higher rank to be more 'civilised' than lower classes. ${ }^{247}$ In Saint-Sauveur's 1798/99 Tableau des principaux peuples de l'Afrique the couple representing the Jaggas are the 'man and woman of quality' - the man is depicted sitting with his legs crossed. While many of the African men carry weapons, these are mere props and no one is particularly aggressive - like the Tableau of Oceanic peoples they are in harmonious couple or family groupings. In the 1806 edition, the Jaggas (fig. 93) are a combination of elements from the 1796 Anzikos warrior and the Jagga man and woman of quality, as is the 1806 Anzikos

245 "Ils sont fort noirs et difformes...". Les Anzikos et les Jaggas, 1806, p. 1

246 “Ils ne plantent ni ne sèment, et n'entretiennent pas de troupeaux: ils ne tirent leur subsistance que de leurs rapines, et de leurs brigandages. Ils aiment sur-tout le pays où ils trouvent des palmiers, étant passionnés pour le vin, et le fruit des ces arbres." Les Anzikos et les Jaggas, 1806, p. 2

${ }^{247}$ Although, perhaps too much should not be made of this, as his King of Congo has the same facial expression as the Man of the Coast of Grains, although he is better dressed. 
couple (fig. 94). In his 1796 edition, perhaps his most derogatory images are of Africans some appear as lacking in intelligence, they are either pleasure-loving or aggressive, and without occupations except as slave-dealers or warriors.

The common European belief that skin colour was a result of climate meant that some Europeans had difficulty in accounting for the American Indians, many of whom occupied a similar climate to parts of Europe. In common with other writers at the time, Saint-Sauveur frequently uses the term basané (suntanned), as well as olivâtre, to describe the skin colour not only of American Indians, but also Asians, some Africans and the Spanish. According to Olive Dickason, the term basané had strong connotations with rusticity and lack of sophistication, "and so in effect equated Amerindians with the European peasantry". ${ }^{248}$ Although very few of Saint-Sauveur's people are depicted with a different skin colour (except the Africans), the Iroquois are slightly darker than his Europeans. His 1796 images of Iroquois show a fairly savage people - he has a Guerrier Iroquois (fig. 95) showing one scalping another, a Sauvage Iroquois, an Iroquois allant a la Découverte (Iroquois going off on a search) (fig. 96) - all aggressively posed - and his Grand Chef de Guerriers Iroquois carries weapons, although he also wears some European clothing (fig. 97).

Clothing played an important role in intercultural contact with the Iroquois - clothes were often given as presents by European settlers (as Timothy Shannon argues - clothing "acquired considerable importance as a tool of diplomacy" ${ }^{49}$ ). Indians in the area wore European clothing, but in a distinctive way that was recognised as the 'Indian fashion', which favoured certain loose-fitting styles, colours and fabrics. ${ }^{250}$ European traders gave different presents to warriors and 'sachems' (leaders) that matched their own ideas of hierarchy; the latter were more likely to receive English-style coats, hats and ruffled shirts, as Saint-Sauveur's Iroquois Chief shows. The Iroquois allant a la Découverte shows most of the weapons used by the Iroquois in the eighteenth-century. By the 1760s Iroquois had been using muskets for over a century, which had largely replaced the bow and arrows for warfare, although these were still used by boys and for hunting small game. The ball-

\footnotetext{
${ }^{248}$ Dickason, p. 144.

249 Timothy J. Shannon, 'Dressing for success on the Mohawk frontier: Hendrick, William Johnson, and the Indian fashion', The William and Mary quarterly, $3^{\text {rd }}$ series, 53(1) January 1996, p. 18.

250 ibid., p. 21.
} 
headed club and the tomahawk were still in use. ${ }^{251}$ However, to add interest, SaintSauveur's Iroquois also wears snow shoes, although he is not depicted in snow.

Saint-Sauveur's text on the Iroquois (called the 'savages of Canada') conveys some of the same messages as his images, and yet (unlike the Anzikos and Jaggas) he also has some positive things to say about them. They are independent, courageous, put a very high value on friendship, and he adds:

If one is astonished to find at the end of the world, in savage people, the use of make-up, patches and all the ridiculous things of Europe, one is much more [astonished] to find there a government worthy to be used as a model for the most organised nations ... They are skilful, hard-working, intelligent, virtuous, a good friend, a good husband, good father. How would it be if philosophy organised their hearts and manners! But perhaps they would lose - they would become a people more civilised but corrupted. ${ }^{252}$

This is one of his clearest expressions of 'noble savage' ideas or Rousseau's 'man of nature' corrupted by 'civilisation'. Cornelius Jaenan writing on French views of American Indians has said that contradictory interpretations emerged fairly early - the 'natural man' versus the 'cannibal savage'. ${ }^{253}$ Saint-Sauveur's text expresses both views. His images and text are therefore not entirely in agreement - there is little 'noble' in his depictions of the Iroquois, except perhaps the chief - in fact the 'Jaggas of quality' are more noble in appearance, despite what he says in their text.

In contrast to the Iroquois, Saint-Sauveur describes the Californians as stupid, weak, indolent and inconstant. Their only virtue seems to be the skill with which they make fishing boats and nets. ${ }^{254}$ Bankes makes a similar comment - "their greatest ingenuity

${ }^{251}$ George Hamell, 'Mohawks abroad: the 1764 Amsterdam etching of Sychnecta' in Christian Feest (ed) Indians and Europe: an interdisciplinary collection of essays, Lincoln \& London: University of Nebraska Press, (1989) $2^{\text {nd }}$ ed. 1999, p. 188.

252 "Si l'on est étonne de trouver au bout du monde, chez un peuple sauvage, l'usage des fards, des mouches et de tous les ridicules de l'Europe, on l'est bien plus encore d'y trouver un gouvernement digne de servir de modèle aux nations les plus policées ... il est adroit, laborieux, intelligent, vertueux, bon ami, bon mari, bon père. Que seroit-il donc si la philosophie poliçoit son âme et ses mœurs! Il y perdroit peut-être: il deviendroit un peuple policé, mais corrompu. "Sauvages du Canada, 1796, pp. 6 and 8.

${ }^{253}$ Cornelius Jaenen, "“Les sauvages Ameriquains": persistence into the $18^{\text {th }}$ century of traditional French concepts and constructs for comprehending Amerindians', Ethnohistory, 29(1), 1982, p. 45.

254 "Ce qui les caractérise principalement, est l'indolence la bêtise, le défaut de réflexion et l'inconstance. On auroit de la peine à trouver une nation plus stupide, plus bornée et plus foible, tant au physique qu'au moral. Leur intelligence se borne à ce qu'ils voient ; les raisonnements les moins appliqués sont hors de leur portée...Les plus industrieux font des bateaux et des filets pour la pêche, et l'on vante l'art avec lequel ils les travaillent." Californie, 1796, pp. 2 and 7. 
appears in their fishing nets, which are made with admirable skill". ${ }^{255}$ Although the English books illustrate the people at the water's edge with fish and boats, no one shows one of the ingenious nets. The English books' source is George Shelvocke's A voyage around the world, 1726. ${ }^{256}$ Middleton (fig. 98) has stayed closer to the source images than Millar. It is difficult to say if Saint-Sauveur has used the same sources - his Californians wear feathers and grass skirts typical of many of his 'savages'. The pose and the weapon the man has in his belt (fig. 99) look similar to those of the man in Shelvocke's Californian image; however his woman bears little resemblance to Shelvocke's two Californian women (who both wear more clothes than Saint-Sauveur's woman). In common with a number of SaintSauveur's images he has added clothing to the men where they wore none in the likely source image, and taken it off the women where they wore more in the source. In his 1806 edition Saint-Sauveur is even more inventive and the Californian man now wears headwear perhaps more suggestive of a stereotypical 'Oriental' (fig. 100). Saint-Sauveur's images do not really match his text. His representations of Californians are not so different from many of his Oceanic peoples; in fact the Californian woman is very similar to the woman of Tanna (see inset).

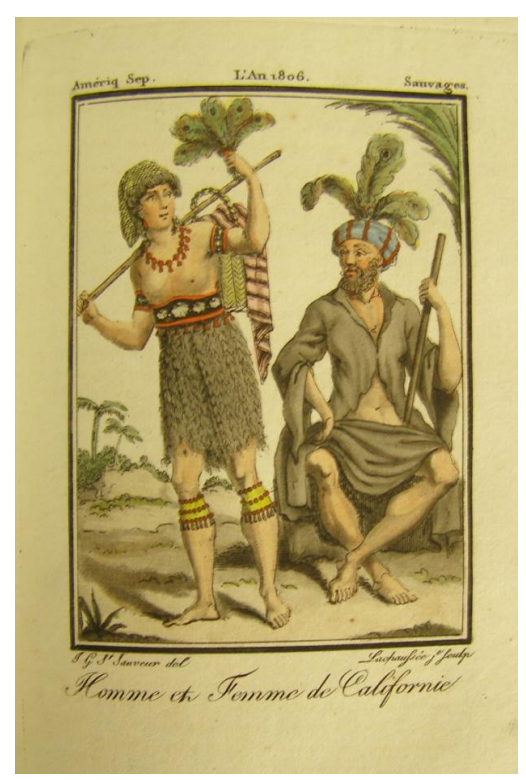

Fig 100

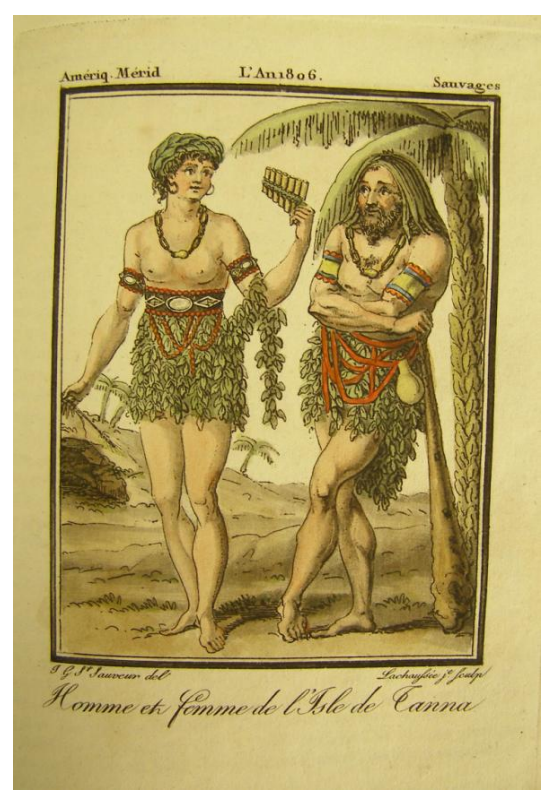

Fig 28

\footnotetext{
${ }^{255}$ Bankes, p. 510.

${ }^{256}$ George Shelvocke, A voyage around the world by way of the great South Sea... London, 1726, Eighteenthcentury collections online, VUW Library, accessed 8 July 2009.
} 
Unlike the Iroquois, the Californians are not described as aggressive, yet Saint-Sauveur has higher praise for the Iroquois, suggesting that, despite his comments about their savagery, he admires them for their courage more than he does the peaceful Californians. It should be remembered that among the attributes of the personification of Europe were implements of warfare and Europe's conquests were praised. ${ }^{257}$ Also, as Bernard Smith noted, the republican virtues praised in France during the revolutionary years brought the ideals of 'hard primitivism' back into favour - "simple in his needs and desires, self-disciplined, courageous, and with a great capacity for endurance, the savage became a symbol of revolutionary freedom". 258

So how do the representations of the Oceanic peoples compare with these others? There is very little to distinguish them from other 'savages', especially those of America if it were not for the captions labelling their location many could easily be substituted for American Indians. As with some other countries, the Oceanic islands text and images do not always convey the same messages. As most of the authors' information on Oceania came from the Cook voyages, they tend to follow the opinions expressed in those written accounts. As chapter 1 showed, these views reflected preconceived ideas, but also how the Europeans were received by the locals, and ranked peoples along a continuum from more 'advanced' to less. Saint-Sauveur says of the New Zealanders - who are around the middle of the continuum:

These cannibals, who for the honour of humanity should be still unknown to us, prepare for war as a delicious feast ... [But] by one of those dreadful contrasts that ignorance so often produces in savage people, these sanguinary monsters in time of war, practise in times of peace all the domestic and social virtues ... they are of a modesty not very common in the savages. ${ }^{259}$

Yet, although Saint-Sauveur's two New Zealand men carry weapons, taking his four New Zealand images together (see figs. 36, 38, 42, and 43), they are hardly depicted any more 'savagely' than other Oceanic peoples. As mentioned in Chapter 4, the most aggressive of

${ }^{257}$ For example, Saint-Sauveur's Europe introduction, 1806, p. 2 -The conquests of the Europeans surpass other nations for their bravery ("les conquêtes ... que les Européens surpassent les autres nations par leur bravoure").

${ }^{258}$ Smith, 1984, p. 149.

259 “'Ce peuple antropophage, qui pour l'honneur de l'humanité devroit nous être encore inconnu, se prépare à la guerre comme à un délicieux festin ... Par un de ces contrastes affreux que l'ignorance produit si souvent dans des peuples sauvages, ces monstres sanguinaires en temps de guerre, pratiquent en temps de paix toutes les vertus domestiques et sociales ... ils sont d'une modestie bien peu commune chez les sauvages." Sauvages de la Nouvelle Zelande, 1796, pp. 5, 6. 
Saint-Sauveur's Oceanic peoples is the Marquesan island man, despite the Cook voyagers ranking the Marquesan people near the top of their hierarchies of Oceanic peoples; but this is an image that likely pre-dates the Cook voyages, and does not match the Cook voyage art, or the description of them in Cook's or Saint-Sauveur's texts. The 1806 representation of a Marquesan couple (fig. 101 and inset below) uses the same pose of the man from the 1796 edition and adds the woman, but her pose is changed to give some interaction with the man (although this is ambiguous - is she attempting to restrain him?) The 1798/99 tableau had already included a representation of a Marquesan couple (see fig 49) as had Dufour and Charvet's wallpaper (see fig 56). While a Sandwich Island warrior is also depicted aggressively (in keeping with their reputation as the people who killed Captain Cook), the Oceanic peoples are shown as no more, and perhaps a bit less, aggressive than some of his African and American peoples. But in common with many other 'savages' they have feather headdresses and grass skirts. I will now discuss dancing, as an example of a commonly depicted custom, or art form.

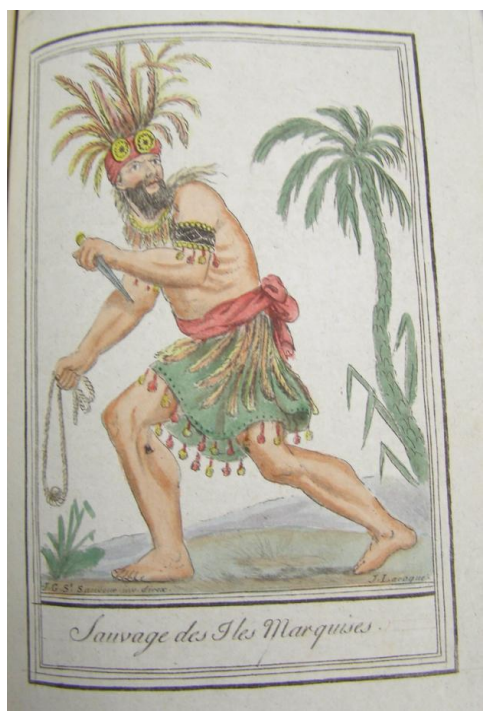

Fig. 55

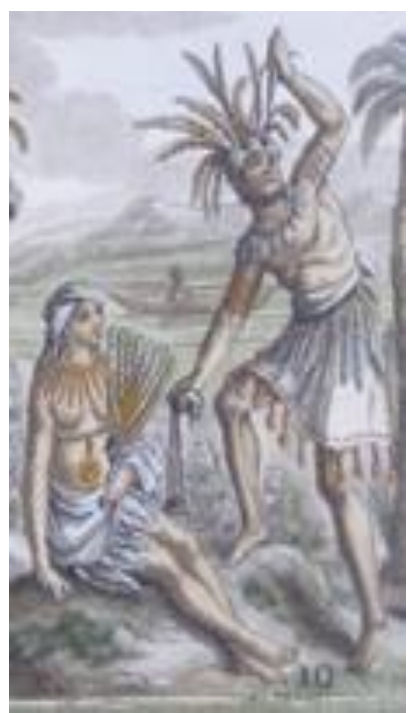

Fig. 49 (detail)

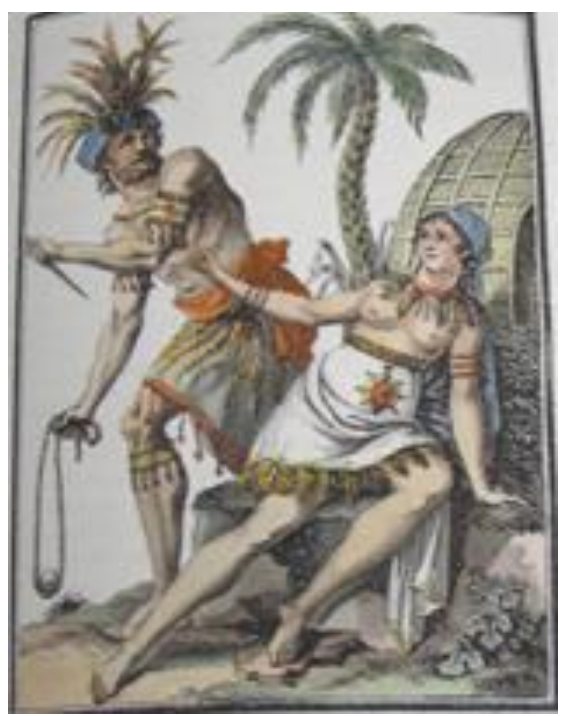

Fig. 101 
"What a charming amusement for young people this is, Mr Darcy! There is nothing like dancing after all. I consider it one of the first refinements of polished societies." "Certainly sir; and it has the advantage also of being in vogue amongst the less polished societies of the world. Every savage can dance". 260

One activity that appears to defy territorial distinctions is dancing. But there are different levels of 'civilisation' attached to different types of dancing. According to Bernard Smith, as European thought was preoccupied with the philosophy of mankind and nature at the time, the people of Oceania made a much stronger impression than their arts did. ${ }^{261}$ Their arts tended to appear as attributes of adornment and dress, or are illustrated separately as ethnographic objects; and actual ethnographic objects brought back from the voyages tended not to fare very well either - according to Marshall and Williams they remained "curiosities, evocative of remote lands and strange people, but no more". ${ }^{262}$ However, music and dance were exceptions -Smith says, "dances made the most lasting impression" for "dances were interpreted as evidence of savage freedom" - and through engravings, textual accounts, popular theatre and ballet they became widely known throughout Europe, "until more than any other single activity they came to symbolise island life itself". ${ }^{263}$ Yet, dancing was popular everywhere and both Saint-Sauveur and the English universal geographies include a relatively high number of images of dancing people from various parts of the world, but notably few from Europe.

Dancing among the European wealthier classes was one of the few activities at the time that allowed physical contact between the sexes in public, as well as providing opportunities for social contact, display and courtship. As part of the general interest in exotic places, many French ballets were performed around themes of other cultures - for example, Turks, Incas, and sauvages of America. However, accuracy in costume was not an important feature - as Joellen Meglin shows the costumes used in French ballet for American Indians were often reused costumes of fauns, dryads and other 'woodland spirits' from classical mythology. ${ }^{264}$ Dancing was also a popular subject in the depictions of early

\footnotetext{
${ }^{260}$ Jane Austen, [1813], Pride and prejudice, Oxford: Oxford University Press, 1957, p. 22.

261 Smith, 1984, p. 123.

${ }^{262}$ Marshall and Williams, p. 59.

${ }^{263}$ Smith, 1984, p. 123 and p. 127.

264 Joellen Meglin, 'Sauvages, sex roles, and semiotics: representations of Native Americans in the French ballet, 1736-1837, part one: the eighteenth century', Dance chronicle, 23(2), 2000, p. 90. An exception was
} 
contact between European and non-European peoples in America. ${ }^{265}$ Dance was often part of the displays of living 'exotic' peoples in Europe, which occurred relatively frequently in the seventeenth and eighteenth centuries, the cultural setting being re-created to convey the impression of activities which were appropriate to the 'primitive' people in question. ${ }^{266}$

Although popular among all classes, it is notable that the books in this study depict dancing only among non-Europeans or, rarely, among the rural or poorer classes of Europe. Two examples of the latter are Catalans dancing the fandango (Saint-Sauveur, fig. 102) and Italians dancing a 'Tarantula' (Middleton, fig. 103), which are both placed in a rural landscape. The latter look particularly 'rustic' and this may be more a comment on a 'quaint' local custom than about dancing per se (it also depicts the tarantula spider and its full title is "The tarantula with the method of curing those stung by it, which is effected by music and dancing”). ${ }^{267}$ Although dancing is mentioned among the amusements of Europeans, for some 'savages' it is said to comprise a large part of their activities - in Saint-Sauveur's introduction to America in the 1796 edition (and repeated for SaintDomingue) he says the people eat and dance during a good part of the day, and pass the remainder of the time asleep ${ }^{268}$ (this is, of course, when they are not hunting or at war, which is said to be how the Iroquois spend their day ${ }^{269}$ ).

Moreau de Saint-Méry (1750-1819, a lawyer and politician) wrote a history of dance in the West Indies (1789) and suggested the manner in which a people danced might be a measure of relative civilisation - 'savages' having simple dance steps, whereas 'civilised' Europeans had more complex ones. ${ }^{270}$ Earlier, the English artist William Hogarth had expressed similar ideas in his book Analysis of beauty (1753), claiming the gentry danced the minuet with graceful curves, while country dances were entertaining but lacked such grace, and the dances of 'barbarians' were only composed of wild skips, jumps,

the play 'Omai' of 1785; the designer Phillipe-Jacques de Loutherbourg based the costumes on images from Cook's voyages.

${ }^{265}$ Mason, 1998, p. 174, footnote 11.

266 ibid, p. 113.

267 Although this does not say they are Italians, the illustration is in the Italian section of the book: vol. 2, facing page 392 .

268 "Une indolence extrême...ennemis du travaille...Après avoir dansé une partie du jour, ils employoient le reste du temps à dormir." Saint-Domingue, 1796, p. 3.

269 "La chasse et la guerre partagent tous les momens des Canadiens; la chasse a pour objet de satisfaire leurs besoins; la guerre n'a presque jamais d'autre but que celui de faire des prisonniers et de les massacrer." Sauvages du Canada, 1796, p. 3.

${ }^{270}$ Cohen, p. 78. 
turns and distorted gestures. ${ }^{271}$ Saint-Sauveur may be reflecting such ideas when he makes comments about the ways 'savages' dance, for example, he says the Iroquois dances "are absolutely similar to those of the other savages" - dancing in a round circle to the beat of an instrument and hand-clapping of spectators. ${ }^{272}$ Although he does not illustrate this, Bankes's illustration of Hottentots dancing (fig. 104) accords with this description and may be part of the stereotype of 'savage' dancing. Their near-naked dancing would look wild and unrestrained to a European viewer. On the other hand, the Kamtschadales' dance is said to little resemble that of 'other savages' - according to Saint-Sauveur the charm of the dance is only in the movement of the head and shoulders. ${ }^{273}$ Bankes says of the Kamtschadales that their dance is intended to represent the clumsy gestures of the bear, and if "the Russian dance is unmeaning and ridiculous, the Kamtschadale is infinitely more so ... to describe the awkward postures exhibited on these occasions would appear tedious and uninteresting". 274

Saint-Sauveur says of the dances of the Sandwich Islands that they are "regulated by the sound of a bad drum, are extremely long and extremely monotonous". ${ }^{275}$ In his 1796 edition, Saint-Sauveur depicts a man of Natal dancing (Sauvage de la Terre de Natal) (fig. 105), and although his Sandwich Island dancer was loosely based on an engraving after John Webber, there is some resemblance between his dancers of Natal and the Sandwich Islands (see fig. 23 and inset below). The Natal dancer appears in the African Tableau of 1798/99, but representing Senegal, while the Anzikos warrior (see fig. 90) with his bow is here representing Benin. It is likely Saint-Sauveur has rearranged the figures in the Tableau in the interests of the composition, or they have simply been mislabelled. So although the Oceanic peoples' dances made an impression on Europeans as Smith says, I doubt that they were seen any differently from other 'savages' dances, especially in these illustrated

\footnotetext{
${ }^{271}$ William Hogarth, Analysis of beauty, 1753, London, Eighteenth-century collections online, VUW Library, accessed 5 August 2009, p. 150.

272 "Les danses des Iroquois sont absolument semblables à celles des autres sauvages; ils dansent en rond au son du chickikoué et des battemens de main des spectateurs." Sauvages du Canada, 1796, p. 8.

273 "La danse...ressemble peu à celle des autres sauvages; les danseurs sont à genoux, les reins immobiles et les mains jointes; c'est dans le mouvement des épaules et de la tête que consiste tout le charme de cette danse." Kamtschatka, 1796, p. 8.

${ }^{274}$ Bankes, p. 118.

275 "Leurs danses, réglées par le son d'un mauvais tambour, sont fort longues et fort monotones." Iles des Sandwich, 1796, p. 5.
} 
encyclopaedias. Along with feather headdresses, clubs, and grass skirts, they could be seen as another typical attribute of a 'savage'.

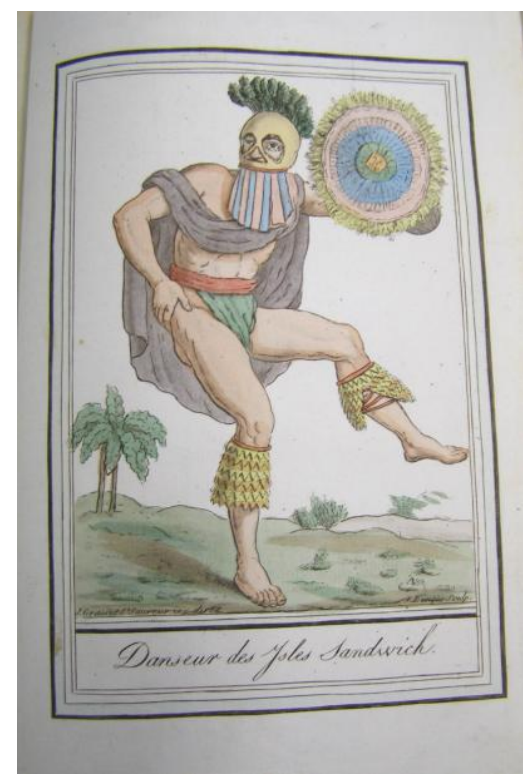

Fig. 23

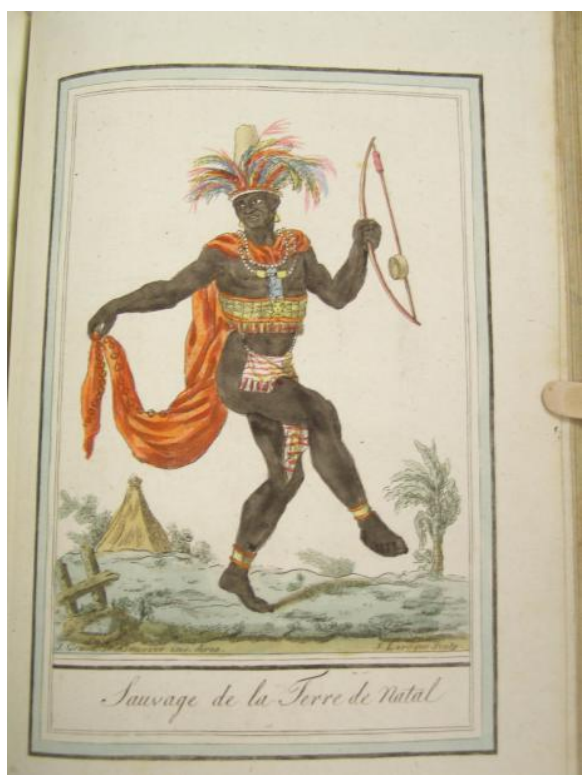

Fig. 105

There is not much difference in the presentation of Oceanic peoples compared with other 'savages' - if they are shown as slightly less aggressive than some others that is probably because the art from Cook's voyages showed little of the violence, or cannibalism, that was described in the texts. ${ }^{276}$ But compared to Europe and some parts of Asia there is a clear distinction - Saint-Sauveur's Europeans are clothed and they are also placed in a context (in front of buildings, for example). Bernard Smith discussed the role of background or landscape in ethnographic images: "Landscape settings became an important element in the ennobling of savages. Portraits of natives devoid of such settings tend, on the whole, to be more truthful". ${ }^{277}$ Saint-Sauveur provides many of his European subjects with a background - buildings for his Parisians, a harbour for the Bordelais - but very little background for many of the non-Europeans, including his Oceanic peoples. ${ }^{278}$ Of course, none of these are meant to be portraits, but to show 'typical' costume; however, to our eyes, few of his Oceanic peoples could be said to be 'truthful'. Saint-Sauveur's lack of much background tends to create a certain uniformity - all 'savages' share similarities - and,

\footnotetext{
${ }^{276}$ Joppien and Smith, 1985-7, vol. 2, p. 74.

${ }^{277}$ Smith, 1984, p.40.

${ }^{278}$ They may have stylised 'tropical' vegetation, such as a palm tree, and a hut.
} 
combined with his tendency to use similar poses for different peoples and combine elements from various sources, has the effect of equalising the images. They are not seen as independent or individual peoples as they have no natural environment or context - which I believe contributes to their exoticism. By seeing Oceanic peoples as add-ons to America it was easy to fit them into existing prejudices about 'savages' and into existing pictorial conventions for depicting 'savages'. Yet in conforming to the conventions of exotic representations, such as those identified by Peter Mason (see chapter 1) - non-specificity, evocation of antiquity, and assuming details applying to a more-documented people could be applied to lesser known peoples - such representations achieve a certain 'authenticity'. It is likely that a readership expecting to see feather headdresses would regard the images as 'truthful'. 


\section{Chapter 6-Conclusions: what the 'curious enquirer' found in the illustrated encyclopaedias}

I have always thought with you, that we possess at this time very great advantages towards the knowledge of human Nature. We need no longer go to History to trace it in all its stages and periods ... Now the Great Map of Mankind is unrolld at once; and there is no state or Gradation of barbarism, and no mode of refinement which we have not at the same instant under our View. The very different Civility of Europe and China; The barbarism of Tartary, and of Arabia. The Savage State of North America, and of New Zealand. ${ }^{279}$

Travel literature was very popular in the late eighteenth century. The English and French books in this study went through several editions (Bankes's, for example, six editions from 1775 to 1797). Other indications of the popularity of Saint-Sauveur's books were their use as designs for the Dufour scenic wallpaper and for a set of ten Limoges porcelain plates; their reference in other costume books (such as the Dutch book by Martinus Stuart); and they are still the sources for some nineteenth-century popular geography books, for example an 1825 French book. ${ }^{280}$ Why was this literature so popular? A partial explanation could be that the exotic was a way to escape from social, political and economic realities at home. But, also, comparison was one of the key methodologies of enlightenment thinking and other societies were compared to one's own. For some of the voyagers, experience of Oceanic island societies caused them to question their own. While the exotic travel genre was also used by philosophical writers such as Jonathan Swift and Denis Diderot to question their own societies, their writing was more about the kind of ideal society they would like at home than about other peoples. No doubt people enjoyed reading about exotic places with unusual customs and better climates than their own, but at the more popular level of these illustrated encyclopaedias, it is likely that most readers would have finished them feeling that their European-civilised ways were affirmed as superior. And while Bernard Smith may have been right to argue that the art of Cook's voyages helped bring about changes in European art into the nineteenth century, at the level

\footnotetext{
${ }^{279}$ Edmund Burke, 9 June 1777; letter to William Robertson, quoted in Marshall and Williams, 1982, facing title page.

${ }^{280}$ La Géographie en estampes ou moeurs et costumes des différens peuples de la terre Paris, 1825, chez Lecerf, graveur, et $\mathrm{P}^{\mathrm{re}}$ Blanchard, ATL. Limoges plates, first quarter of 19th century, Musée national de la porcelaine Adrien Dubouché, Limoges; three illustrated in D'un regard l'autre: histoire des regards européens sur l'Afrique, l'Amérique et l'Océanie, p.140.
} 
of these popular illustrated books, economic imperatives of the book trade drive a conservatism and a recycling of images.

Ideas about other groups of people having certain characteristics have a long history in European thought. The Medieval encyclopaedist, Isidore of Seville, for example thought Romans were serious, Africans crafty, and Gauls proud and fierce. ${ }^{281}$ Nicholas Hudson argues that these, and similar ideas in travellers' accounts, were assimilated into 'scientific' thought in the mid-eighteenth century by natural historians such as Linnaeus, Buffon, and Blumenbach; which in turn systematised them and gave them more credence. Both Linnaeus's and Buffon's criteria for categorising human beings included moral characteristics as well as physical ones. The view that different societies represented different stages of development was shared by many Enlightenment philosophers, as discussed in chapter 1 and as shown by Edmund Burke's quote at the head of this chapter. Readers of the illustrated encyclopaedias might assume that contemporary 'savages' were at a similar stage of 'primitiveness' to Europeans' primitive ancestors who were believed to have worn leaves and feathers. However, in the eighteenth century, movement between the stages was generally not seen as racially determinative as it was to become in the nineteenth century, and all societies were at least thought capable of moving from savagery to civilisation - it was only late in the eighteenth century that a more historical view of 'progress' took hold, where certain societies did not or could not progress. ${ }^{282}$ Although these books did not create the stereotypes, they did reflect and perpetuate them into the nineteenth century. Some stereotypes have been long-lasting - for example, rustic rural Europeans versus civilised city-dwellers and in Oceania the views of a Pacific 'paradise' have been perpetuated by colonial governments and promoters of tourism, as Miriam Kahn argues:

Although these images were first created by romantic imaginations to transport Europeans to another world, they soon became wilfully employed as a political and economic tool to serve colonial agendas, to attract tourists and their money ... By now they have become an integral and indispensable component of French Polynesia's political economy. ${ }^{283}$

\footnotetext{
${ }^{281}$ Nicholas Hudson, "From "nation" to "race": the origin of racial classification in eighteenth-century thought', Eighteenth-century studies, 29(3), 1996, p. 248.

282 Jacques, p. 213.

${ }^{283}$ Miriam Kahn, 'Tahiti intertwined: ancestral land, tourist postcard, and nuclear test site', American anthropologist, new series, 102(1), March 2000, p. 22.
} 
Saint-Sauveur's lack of interest in physiognomy reflects a fairly common strand of European thinking at the time, that humanity shared a common nature - their clothing and ornaments were their main identifying characteristics, with some exceptions such as Africans. Bernard Smith believes the depiction of people as "noble", while Eurocentric, did at least contain a vestige of the view of the dignity of all men. Eventually, although more in the nineteenth century, a new emphasis on comparative anatomy led to new proposals for ethnic portraiture and a decline in interest on the old emphasis on dress and adornment. ${ }^{284}$ In the later eighteenth century, the English and French were, as Smith argues, "slowly but surely ceasing to be diverted, instructed, and amused by savages." ${ }^{285}$ Katharine Fullagar offers one reason for this, at least in relation to England - in the eighteenth century until about 1780, British public discourse centred on the transition to commercialism. 'Savages' (as an alternate way of being) were useful for a population struggling to understand, or resist, the moral fall-out of transformation. From about 1780 discourse shifted to ways to reform or consolidate commercialism and 'savages' were less useful to that debate. ${ }^{286}$ Other reasons include the increasing evangelicalism in England, and the conservative backlash against the excesses of democracy as shown in republican France during the 1790s. In France, although the republican years brought ideals of 'hard primitivism' back into favour, the years of the Napoleonic wars would have focussed French interest back onto Europe. Also no government-sponsored voyages to Oceania were made in these years.

J. G. A. Pocock has argued that the most important encounter made by Europeans in the Age of Enlightenment was the encounter with themselves, with their pasts, and their own historicity. ${ }^{287}$ And T. Carlos Jacques develops this theme, arguing that to the extent they were concerned with the past, it was for the purpose of comparing the past and present to discern social or political types of organisation, or for the purpose of a moral or political critique of the present - in other words the object of history is moral at this time. ${ }^{288}$ Other peoples were useful for comparative purposes, but by the end of the century this usefulness

\footnotetext{
${ }^{284}$ Smith, 1992, pp. 61-62 \& 187.

285 Smith, 1984, p. 137.

286 Fullagar, thesis abstract.

287 J. G. A. Pocock, 'Nature and history; self and other: European perceptions of world history in the age of encounter' in Alex Calder, Jonathan Lamb and Bridget Orr (eds), Voyages and beaches: Pacific encounters, 1769-1840, Honolulu: University of Hawai’i Press, 1999, p. 29.

288 Jacques, p. 206.
} 
was diminishing. These illustrated encyclopaedias, however, were still riding the wave of popularity in travel literature and the exotic.

In chapter one I discussed curiosity and exoticism as frameworks for analysing the images in the illustrated encyclopaedias. Curiosity is a term that features prominently in travel books of the time, as do entertainment and usefulness - specified as the twin aims of the books. The idea of curiosity was somewhat ambiguous at the time, but I believe it encompassed both entertainment and usefulness - a desire for knowledge but in an entertaining way. For example, the Rev Fordyce in his sermons for young women could recommend travel literature as "amusing to [their] curiosity". The 'curious' are likely to be more tempted by the senses than by the intellect - and hence the images might have greater appeal than the text. Curiosity could be used as a way of trying to regulate or control knowledge - for example, Johann Forster on Cook's second voyage contrasted his 'scientific' curiosity with the sailors' greed in collecting 'curiosities'. Yet curiosity was also seen as a marker of civilisation, and said to be lacking in 'savages'. A common object of curiosity was interest in the 'exotic' - other countries and peoples. This was popular especially as a way of comparing one's own society with others. It was also a way of appropriating or taming the unfamiliar. It may seem paradoxical to argue, as I have, that Europeans had only a superficial interest in others, when 'curiosity' is so widespread in the literature, yet as Edmund Burke noted at the time (see chapter 1), curiosity reflects a love of novelty and therefore new things are constantly sought to whet the appetite.

My reasons for choosing a selection of illustrated encyclopaedias from this era are that these are the first of their genre to feature Oceanic peoples and I wanted to see how curiosity about 'newly discovered' peoples was handled in genres that were of longstanding, and also to see how they represented Oceanic peoples visually and what this said about Europeans and their relationships with others. Did Oceanic discoveries challenge prevailing views or were they incorporated as just the newest 'savages'? The book genres the English universal geographies and the French costume books were part of developed in the sixteenth century. The book format imposed traditions of presentation, pictorial conventions, and reproductive techniques. The images tend to follow genre traditions and where possible use pre-existing source images rather than create new images to illustrate the text - the competitive book market made economy of effort matter more than images and text matching. The images therefore sometimes 'tell' a different story from the text 
and, as I have argued in previous chapters, were just as much to please the eye as to present information. Despite the popularity of the travel genre, I believe that European interest in others was fairly superficial and mainly a way of escaping into the 'exotic' and comparing other societies with one's own - and for readers of these encyclopaedias - benefiting from the comparison.

The frontispieces to the books offered a visual summary of the key ideas in the books. All the frontispieces in this study show female personifications of the four continents - the English books depict the four together while Saint-Sauveur depicts each separately at the beginning of his discussion of each continent. The frontispieces embody moral value judgements and reveal European views of political, social and economic relations between Europe and other peoples and countries at that time. Attributes of the four continents became standard by the early seventeenth century and lasted well into the nineteenth. Even when new knowledge became available (or new images from recent voyages) the personifications were not usually changed, as they needed to be recognisable to a European audience. America, which at this time usually included Oceania, was generally depicted as a 'savage' although in Saint-Sauveur's 1806 edition she appears to be more 'civilised' than in the 1796 edition. After the United States achieved independence in 1783 the earlier view of America became increasingly outdated. Despite the illustrated encyclopaedias including the latest Oceanic discoveries, on the whole their frontispieces remain traditional, and by subsuming Oceanic peoples under America, they say practically nothing about this part of the world. As a summary of the narrative of the book, the frontispieces therefore could be seen as incomplete, but they clearly reveal European views of their own superiority, which colours their views of the other parts of the world.

So how did the books incorporate Oceania? The English geographies, on the whole, stayed fairly close to the source images, which were mainly taken from the published accounts of Captain Cook's voyages. This fitted with the format of their books, which, for other continents, also used explorers' accounts or general histories, and reproduced black and white engravings. However, the authors of the universal geographies (particularly the Rev. Thomas Bankes (Vicar of Dixton) and Charles Middleton) imbue their texts with a strong religious viewpoint. Whereas Saint-Sauveur occasionally reflects some views of the French Enlightenment (such as anti-religious and 'noble savage' sentiments) the English authors do not express such ideas. They saw European values as universal - for example, 
Bankes, in the Tahiti text, says the Tahitians "have not an idea of any thing being indecent and transgress the rules of modesty without the least sense of shame, or notion of impropriety", as if there was no doubt what these 'rules of modesty' were. ${ }^{289}$ He makes judgements on others but rarely attributes any blame to English travellers, for example, venereal disease is 'said' to have been introduced to New Zealand by an unknown ship a few years before the Endeavour arrived; and, in Tahiti, Bougainville's voyage is blamed for introducing it ${ }^{290}$ (although the English under Captain Wallis were there earlier). A New Zealand boy on being given alcohol by the English sailors is said to have "exhibited a very just sample of the impatient temper of those people". ${ }^{291}$ His 'Address to the reader' explains the advantages readers ("speculative enquirers") will gain by reading his book:

And how engaging must it be to speculative enquirers to contemplate on the uncultivated mind, in various regions, where the absurdist prejudices usurp the place of reason, and cruelty, vice, folly, and tyranny are sanctified by the venerable name of religion. They [readers] will see how much they owe to education, to the embellishment of science, to the purity of our holy religion ... and their brave ancestors for the system of religious and civil liberty handed down to them. ${ }^{292}$

As the images stayed close to the original engravings published in Cook's voyages, but the texts, while based on the Cook accounts, were embellished with the authors' religious sentiments and anglo-centric views, I believe the text is more derogatory than the images. Ideas associated with 'noble savages' and 'soft primitivism' are clearly not going to appeal to these authors.

Saint-Sauveur incorporated Oceanic peoples into his books in more inventive ways than the English books did. His pictorial conventions include an emphasis on clothing rather than physiognomy, so the people are depicted full length and their faces are usually non-descriptive. Clothing and adornments rather than physiognomy constitute identity. The background is usually rudimentary or schematic. The representations are of generic types to represent a particular area, or occupations of an area. He also used the art from the published Cook voyage accounts as his main sources for Oceanic peoples, but where there was not a full-body source available he would combine elements from different images. It was relatively easy to fit the 'new' Oceanic peoples into these conventions. Apart from the

\footnotetext{
${ }^{289}$ Bankes, pp 48-49.

${ }^{290}$ Bankes's references to venereal disease: NZ p. 17; Tahiti p. 50.

${ }^{291}$ Bankes, p 16.

${ }^{292}$ Bankes, 'Address to the reader,' unpaginated.
} 
wealthy (fashionable) inhabitants of some European capitals, there is a sense of timelessness in his images. His lack of much background for non-Europeans, his use of similar poses for different peoples and combining elements from various sources, tends to create a certain uniformity. A weapon, club, or dancing, feather headdresses and grass skirts typify 'savages'. However, he does make attempts at accuracy - for example using the pose of a man from an engraving after William Hodges of a general scene in Tanna for his own Man of Tanna, when he simply could have adapted one from another source (as he did for his Easter Island woman). Nevertheless, without their captions, some of his Oceanic peoples could be easily substituted for American Indians.

The images, with their different traditions, can and do differ from the text. Even in the illustrations for the official account of Cook's first voyage, Bernard Smith says Cipriani and Bartolozzi did not consciously set out to ennoble Tahitians - they probably believed like others that one 'savage' is very much like another - they sought rather to conform to the conventions of history painting by suppressing anything in Parkinson's drawings that seemed mean or peculiar. ${ }^{293}$ The illustrated encyclopaedias used these engraved images as sources, but were also following the conventions of their own genre traditions. Competition and keeping costs down meant images and often large amounts of text were pirated / copied; and yet the authors frequently claimed in title pages or prefaces that their books contained new material and original work. Such claims were clearly exaggerated, but must have been important in trying to catch a potential buyer's attention. What is striking is the longevity of some images and their apparent resistance to new information (for example, Saint-Sauveur's Marquesan Island man). In this, they are similar to the allegories of the four continents. This partly reflects the book trade; but also, as I have argued, a superficial European interest in other peoples (one that reinforced rather than challenged existing views).

Comparing the French and English books, the French books are more 'pleasing to the eye' than the English books - there is less text in relation to images, which are coloured; whereas the English books have much more text in relation to images, the text is small and close-spaced, and the images are uncoloured. There is greater variety in the types of images in the English books - the cosmography / geography genre allows more scope

${ }^{293}$ Smith, 1992, p 176 and 178. 
than the costume book genre, which imposes more uniformity, but this also means that the English books appear more eclectic than the French. There is a sense of timelessness in both the English and French books. The English ones could include images from Cook's voyages, along with Sir Walter Raleigh in Virginia, the Sultan Mahomet murdering Irene (an event from the fall of Constantinople in 1453, but performed as a play "Mahomet and Irene" in London in 1749), Caribbeans' partaking in cannibal feasts and Animals of Maragnan (the latter two originating in the sixteenth century). I believe this is further evidence that the authors and publishers were more concerned to entertain and sell books than present accurate, up-to-date, images. But as there is a tendency to see the exotic as timeless, this eclecticism probably did not matter to the readership of the books. In relation to using the art from Cook's published voyage accounts as source material, the English books stay closer to the original than Saint-Sauveur, who more freely adapts the sources to his costume book conventions. On the whole, I think the images in Saint-Sauveur's costume books celebrate diversity (at least diversity of clothing). While the images certainly convey a sense of Europeans as better dressed and more 'civilised' than others, if the reader looked only at the images they would have a different impression than if they read the text as well - some of the more racist comments made in the texts are not conveyed in the images.

The English books, and Saint-Sauveur's editions up to 1796, include some images of non-Europeans as aggressive or warlike, whereas Saint-Sauveur's five tableaux of 1798/99, Dufour's panoramic wallpaper (c.1805) and Saint-Sauveur's 1806 edition give the impression of harmonious family groups with leisure for talking, dancing and games. Although no longer aggressive, they present an idyllic, but, at the same time, indolent lifestyle and there is nothing to suggest they can 'progress' from this state, without European 'help'. These books and prints are an example of the European view of others when European missionary activity and colonisation in Oceania began; such views helped condition their responses to Oceanic peoples and set the scene for years of colonisation and exploitation. The London Missionary Society chose Tahiti as its first place to send missionaries to (after consulting Captain Bligh), and, according to Rod Edmond, "The singular importance of the missionaries is perhaps the most distinctive feature of European 
colonisation of the Pacific". ${ }^{294}$ They had no doubts about the superiority of Christian European civilisation over other forms of society.

I have argued that images of Oceanic peoples in these illustrated encyclopaedias conformed to certain genre traditions and pictorial conventions that tell us more about Europeans' views of themselves than about Oceania. These views included that Europeans were industrious, 'civilised' and more 'advanced' in various ways, such as in social and political structure, economy, and technology. By seeing Oceanic peoples as add-ons to America it was easy to fit them into existing prejudices about 'savages' and into existing pictorial conventions for depicting 'savages'. Yet for an audience who expected to see 'savages' wearing grass skirts and feather headdresses these images would have appeared 'authentic'. My study highlights the more popular views (or at least those of the middling classes) rather than those of writers such as Diderot, or the voyagers' accounts, which understandably have been given more academic attention. These books are overlooked today because they are derivative and their images are not necessarily ethnographically accurate. Yet they were popular in their time. They represent a conservative Eurocentric viewpoint and their inclusion of new material from Oceanic voyages did not challenge these views. Images and texts such as these likely reinforced European views of their own superiority and made it easy to justify missionary activity and colonisation in various parts of the world, particularly Oceania. As the French philosopher Jean-Jacques Rousseau, the most celebrated mouthpiece for the notion of the 'noble savage', prophetically noted:

For the three or four hundred years since the inhabitants of Europe inundated the other parts of the world, and continually published new collections of travels and stories, I am convinced that we know no other men but the Europeans alone. ${ }^{295}$

\footnotetext{
${ }^{294}$ Edmond, 1997, p. 13.

${ }^{295}$ Jean-Jacques Rousseau, The basic political writings ... Discourse on the origins of inequality, [1755] translated and edited by Donald Cress, Indianapolis \& Cambridge: Hackett Publishing, 1987, Rousseau's notes to part 1, note 10, p. 99 .
} 


\section{List of illustrations}

\section{Abbreviations}

ATL - Alexander Turnbull Library, National Library of New Zealand, Wellington.

'Grasset de Saint-Sauveur, Paris, 1796' - Grasset de Saint-Sauveur, Jacques, Encyclopédie des voyages: contenant l'abrégé historique des moeurs, usages, habitudes domestiques, religions, fêtes supplices, funérailles, sciences, arts, et commerce de tous les peuples, Paris: Se trouve chez l'Auteur, rue Nicaise, maison de la Section des Tuileries. Chez Deroy, libraire, rue du Cimitière-Andre no. 15. Et chez les principaux libraires de la République, 1796, 5 vols, ATL.

'Grasset de Saint-Sauveur, Paris, 1806' - Grasset de Saint-Sauveur, Jacques, Voyages pittoresques dans les quatre parties du monde, ou troisième édition de l'encyclopédie des voyages: contenant les costumes des principaux peuples de l'Europe, de l'Asie, de l'Afrique, de l'Amérique et des sauvages de la mer du sud, gravés et coloriés avec soin ... Paris: Chez Madame veuve Hocquart, 1806, 2 vols, ATL.

NGA - National Gallery of Australia, Canberra.

NLA - National Library of Australia, Canberra.

VUW - Victoria University of Wellington.

Original French orthography has been retained.

\section{Chapter 1}

Fig 1: Pilgrim with Devotion and Curiosity, engraving, from Conrad Hietling, Peregrinus affectuose per terram sanctam et Jerusalem a Devotione et Curiositate conductus, Augsburg, 1713, illustrated as the frontispiece to Neil Kenny, The uses of curiosity in early modern France and Germany, Oxford \& New York: Oxford University Press, 2004. Reproduced by permission.

Fig 2: Curiosity, engraving, from A collection of the dresses of different nations, antient and modern, London: Thomas Jefferys, 1757-72, vol. 4, Eighteenth-century collections online, VUW library, accessed 4 September 2008 and 20 April 2009. From Gale. Eighteenth Century Collections Online. () Gale, a part of Cengage Learning, Inc. Reproduced by permission. www.cengage.com/permissions.

\section{Chapter 2}

Fig 3: F. Smith, Animals of Maragnan, engraving, from John Moore, A new and complete collection of voyages and travels ... describing, in the most accurate manner, every place worthy of notice in Europe, Asia, Africa, and America, London: Alexander Hogg, 1790, vol. 2, ATL. 
Fig 4: Jacques Grasset de Saint-Sauveur's signature on a receipt bound with Grasset de Saint-Sauveur, Paris, 1806, vol. 2, ATL.

\section{Chapter 3}

Fig 5: Jacques Grasset de Saint-Sauveur and L. Labrousse, Frontispiece de l'Europe, handcoloured etching, from Grasset de Saint-Sauveur, Paris, 1796, vol. 1, ATL.

Fig 6: Frontispiece de l'Europe, hand-coloured etching, from Grasset de Saint-Sauveur, Paris, 1806, vol. 1, ATL.

Fig 7: Jacques Grasset de Saint-Sauveur and L. Labrousse, Frontispiece de l'Asie, handcoloured etching, from Grasset de Saint-Sauveur, Paris, 1796, vol. 3, ATL.

Fig 8: Jacques Grasset de Saint-Sauveur and L. Labrousse, Frontispiece de l'Afrique, handcoloured etching, from Grasset de Saint-Sauveur, Paris 1796, vol. 4, ATL.

Fig 9: Claude-Louis Desrais and Jean Marie Mixelle, Costumes Civils: Amérique, handcoloured etching, from P. Sylvain Maréchal [and Jacques Grasset de SaintSauveur], Moeurs et costumes des habitans de l'Isle Taiti, Paris, 1788, ATL.

Fig 10: Jacques Grasset de Saint-Sauveur and L. Labrousse, Frontispiece de l'Amérique, hand-coloured etching, from Grasset de Saint-Sauveur, Paris, 1796, vol. 5, ATL.

Fig 11: Frontispiece de l'Amérique, hand-coloured etching, from Grasset de Saint-Sauveur, Paris, 1806, vol. 2, ATL.

Fig 12: Jacques Grasset de Saint-Sauveur and Lachaussee jeune, Amazône d'Afrique; Guerriere de la riviere des Amazônes, hand-coloured etching, from Grasset de Saint-Sauveur, Paris, 1806, vol. 2, ATL.

Fig 13: Burder after Samuel Wale, Frontispiece, engraving, from Charles Middleton, $A$ new and complete system of geography containing a full, accurate, authentic and interesting account and description of Europe, Asia, Africa and America ... including the essence of all the most remarkable voyages and travels ..., London: $\mathrm{J}$. Cooke, 17 Paternoster Row, 1777, vol. 1, ATL.

Fig 14: John Neagle after Johann Heinrich Ramberg, Frontispiece, engraving, from Rev. Thomas Bankes, New, royal and authentic system of universal geography ... Europe, Asia, Africa and America ... [and] collection of voyages and travels, London: C. Cooke, 17 Paternoster Row; 1790, ATL.

Fig 15: Robert Pollard, Frontispiece, engraving, from George Millar, The new and universal system of geography: being a complete history and description of the whole world ..., London: Alexander Hogg, 16 Paternoster Row, 1782, ATL. 


\section{Chapter 4}

Fig 16: Jacques Grasset de Saint-Sauveur and J. Laroque, Fille Taïtienne portant des present au roi, hand-coloured etching, from Jacques Grasset de Saint-Sauveur, Moeurs, usages et costumes d'Otahiti ou Taiti, Moeurs et coutumes des habitans des Isles Maquises, Moeurs, usages, lois et costumes des habitans de SainteChristine, Paris: 1784, ATL.

Fig 17: Jacques Grasset de Saint-Sauveur and J. Laroque, Danseuse de Taïti, handcoloured etching, from Jacques Grasset de Saint-Sauveur, Moeurs, usages et costumes d'Otahiti ou Taiti, Moeurs et coutumes des habitans des Isles Maquises, Moeurs, usages, lois et costumes des habitans de Sainte-Christine, Paris: 1784, ATL.

Fig 18: J. K. (John Keyse) Sherwin after John Webber, Young woman of Otaheite, dancing, engraving, from James Cook, A voyage to the Pacific Ocean ..., 1784, NLA online, nla.aus-nk1428-4-s29-v.

Fig 19: Francesco Bartolozzi after Giovanni B. Cipriani, View of the inside of a house in the island of Ulietea, with the representation of a dance..., engraving, from John Hawkesworth, An account of the voyages undertaken by ... Commodore Byron, Captain Wallis, Captain Carteret, and Captain Cook, London, 1773, ATL.

Fig 20: Claude-Louis Desrais? Danseuse de l'Isle O'tahiti, hand-coloured etching, from P. Sylvain Maréchal, [and Jacques Grasset de Saint-Sauveur] Moeurs et costumes des habitans de l'Isle Taiti, Paris, 1788, ATL.

Fig 21: Charles Grignion after John Webber, A man of the Sandwich Islands dancing, engraving from James Cook, A voyage to the Pacific Ocean, 1784, NLA online, nla.aus-nk1428-4-s62-v.

Fig 22: Claude-Louis Desrais? Danseur des Iles Sandwich, hand-coloured etching, from P. Sylvain Maréchal, [and Jacques Grasset de Saint-Sauveur], Costumes civil ..., Paris, 1788, NLA online, pic-an9000421-5.

Fig 23: Jacques Grasset de Saint-Sauveur and J. Laroque, Danseur des Iles Sandwich, hand-coloured etching, from Grasset de Saint-Sauveur, Paris, 1796, vol. 5, ATL.

Fig 24: Francesco Bartolozzi after John Webber, The death of Captain Cook, engraving published separately from the official third voyage account, 1784, NLA online, pican7678346-1-v.

Fig 25: Claude-Louis Desrais? Guerrier de Sandwich, hand-coloured etching, from P. Sylvain Maréchal, [and Jacques Grasset de Saint-Sauveur] Costumes civil...., Paris, 1788, NLA online, pic-an9000421-2-v. (Catalogued as Insulaire d'Owhyhee, by Grasset de Saint-Sauveur and J. Laroque, 1796?). 
Fig 26: Claude-Louis Desrais? Guerrier de Sandwich, drawing, 1788?, NLA online, nla.pic-an6053408-v. (Catalogued as Insulaire d'Owhyhee, 178-?).

Fig 27: Jacques Grasset de Saint-Sauveur and Labrousse, Guerrier de Sandwich, handcoloured etching, from Grasset de Saint-Sauveur, Paris, 1796, vol. 5, ATL.

Fig 28: Jacques Grasset de Saint-Sauveur and Lachaussee Jeune, Homme et femme de l'isle de Tanna, hand-coloured etching, from Grasset de Saint-Sauveur, Paris, 1806, vol. 2, ATL.

Fig 29: William Woollett after William Hodges, $A$ view in the island of Tanna, engraving, from Captain James Cook, A voyage around the world in the years 1772, 1773, 1774 and 1775, London, 1777, NLA online, pic-an10350766-v.

Fig 30: Francesco Bartolozzi after William Hodges, Man of Easter Island, engraving, from Captain James Cook, A voyage around the world in the years 1772, 1773, 1774 and 1775, London, 1777, NLA online, pic-an7682844-v.

Fig 31: Jacques Grasset de Saint-Sauveur and J. Laroque, Homme de l'isle de Pâques, hand-coloured etching, from Grasset de Saint-Sauveur, Paris, 1796, vol. 5, ATL.

Fig 32: Jacques Grasset de Saint-Sauveur and J. Laroque, Femme de l'isle de Pâques, hand-coloured etching, from Grasset de Saint-Sauveur, Paris, 1796, vol. 5, ATL.

Fig 33: J. Caldwell after William Hodges, Woman of Easter Island, engraving, from Captain James Cook, A voyage around the world in the years 1772, 1773, 1774 and 1775, London, 1777, NLA online, pic-an7691921-v.

Fig 34: Thomas Morris, Various dresses of the Indians of North America, engraving, from George Millar, The new and universal system of geography: being a complete history and description of the whole world ..., London: Alexander Hogg, 16 Paternoster Row, 1782, fp. 793, ATL.

Fig 35: Jacques Grasset de Saint-Sauveur and Mixelle jeune, Homme et femme Népissens, hand-coloured etching, from Grasset de Saint-Sauveur, Paris, 1806, vol. 5, ATL.

Fig 36: Jacques Grasset de Saint-Sauveur and J. Laroque, Guerrier de la Nouvelle Zélande, hand-coloured etching, from Grasset de Saint-Sauveur, Paris, 1796, vol. 5, ATL.

Fig 37: Engraving after a drawing by Sydney Parkinson, Head of a New Zealander with a comb in his hair, an ornament of green stone in his ear, and another of a fish's tooth round his neck, from John Hawkesworth, An account of the voyages undertaken by ... Commodore Byron, Captain Wallis, Captain Carteret, and Captain Cook, London 1773, NLA online, pic-an9184920-v. 
Fig 38: Jacques Grasset de Saint-Sauveur and J. Laroque, Sauvage de la nouvelle Zéelande, hand-coloured etching, from Grasset de Saint-Sauveur, Paris, 1796, vol. 5, ATL.

Fig 39: Thomas Chambers after Sydney Parkinson, A New Zealand warrior in his proper dress \& completely armed to their manner, engraving, from Sydney Parkinson, $A$ journal of a voyage to the South Seas, 1773, NLA online, pic-an10203269.

Fig 40: Habit of an antient Britain, engraving, from $A$ collection of the dresses of different nations, antient and modern. Particularly old English dresses, London: Thomas Jefferys, 1757-72, vol. 4, Eighteenth-century collections online, VUW library, accessed 4 September 2008 and 20 April 2009. From Gale. Eighteenth Century Collections Online. (C) Gale, a part of Cengage Learning, Inc. Reproduced by permission. www.cengage.com/permissions.

Fig 41: Jacques Grasset de Saint-Sauveur and Lachaussee jeune, Homme \& femme de la Nouvelle Zelande, hand-coloured etching, from Grasset de Saint-Sauveur, Paris, 1806, vol. 2, ATL.

Fig 42: Jacques Grasset de Saint-Sauveur and J. Laroque, Sauvagesse de la Nouvelle Zelande, hand-coloured etching, from Grasset de Saint-Sauveur, Paris, 1796, vol. 5, ATL.

Fig 43: Jacques Grasset de Saint-Sauveur and J. Laroque, Fille parée de la nouvelle Zeelande, hand-coloured etching, from Grasset de Saint-Sauveur, Paris, 1796, vol. 5, ATL.

Fig 44: Daniel Lerpiniere after William Hodges, Family in Dusky Bay, engraving, from Captain James Cook, A voyage around the world in the years 1772, 1773, 1774 and 1775, London, 1777, NLA online, pic-an7691882-v.

Fig 45: Jacques Grasset de Saint-Sauveur and J. Laroque, Femme Tartar Tobolsk, handcoloured etching, from Grasset de Saint-Sauveur, Paris, 1796, vol. 3, ATL.

Fig 46: Jacques Grasset de Saint-Sauveur and Antoine Phélippeaux, Tableau des découvertes du Cap ${ }^{\text {ne }}$ Cook \& de la Pérouse, hand-coloured etching, Paris and Bordeaux: chez l'Auteur ... et les principaux libraries, 1798/99 (Year 7), NLA online, pic-an5598006-v.

Fig 47: Page after Richard Samuel, Persons and dresses of the inhabitants of the South Sea Islands, engraving, from New discoveries concerning the world and its inhabitants, London 1778, frontispiece to vol 1, ATL.

Fig 48: Jacques Grasset de Saint-Sauveur and Antoine Phélippeaux, Tableau des découvertes du Cap ${ }^{\text {ne }}$ Cook \& de la Pérouse, hand-coloured etching, Paris and Bordeaux: chez l'Auteur ... et les principaux libraries, 1798/99 (Year 7), NLA, detail of NZ couple. 
Fig 49: Jacques Grasset de Saint-Sauveur and Antoine Phélippeaux, Tableau des découvertes du Cap ${ }^{\text {ne }}$ Cook \& de la Pérouse, hand-coloured etching, Paris and Bordeaux: chez l'Auteur...et les principaux libraries, 1798/99 (Year 7), NLA, detail of Marquesan couple.

Figs 50-53: Jean-Gabriel Charvet, Les sauvages de la mer pacifique, block-printed wallpaper, by Joseph Dufour and Co., Mâcon, France, c. 1805, NGA (4 images showing whole paper).

Fig 54: Jean-Gabriel Charvet, Les sauvages de la mer pacifique, block-printed wallpaper, by Joseph Dufour and Co., Mâcon, France, c. 1805, NGA, strips 10 \& 11, showing New Zealand people.

Fig 55: Jacques Grasset de Saint-Sauveur and J. Laroque, Sauvage des isles Marquises, hand-coloured etching, from Grasset de Saint-Sauveur, Paris, 1796, vol. 5, ATL.

Fig 56: Jean-Gabriel Charvet, Les sauvages de la mer pacifique, block-printed wallpaper, by Joseph Dufour and Co., Mâcon, France, c. 1805, NGA, strip 18, showing Marquesan couple.

Fig 57: Jean-Gabriel Charvet, Les sauvages de la mer pacifique, block-printed wallpaper, by Joseph Dufour and Co., Mâcon, France, c. 1805, NGA, strips 4 and 5, showing Tahitian women dancing and musicians playing.

Fig 58: Royce after Daniel Dodd, Representation of the heiva at Otaheite, engraving, from John Rickman's anonymously published journal, Journal of Captain Cook's last voyage to the Pacific Ocean, on Discovery; performed in the years 1776, 1777, 1778, 1779, illustrated with cuts, and a chart, shewing the tracts of the ships employed in this expedition, London: Printed for E. Newbery, 1781, ATL.

Fig 59: Jacques Grasset de Saint-Sauveur and J. Laroque, Fille de Taiti, hand-coloured etching, from Grasset de Saint-Sauveur, Paris, 1796, vol. 5, ATL.

Fig 60: Jacques Grasset de Saint-Sauveur and J. Laroque, Homme de Taiti, hand-coloured etching, from Grasset de Saint-Sauveur, Paris, 1796, vol. 5, ATL.

Fig 61: Claude-Louis Desrais? Femme de l'Isle de Taiti, hand-coloured etching, from P. Sylvain Maréchal, [and Jacques Grasset de Saint-Sauveur] Moeurs et costumes des habitans de l'Isle Taiti, Paris, 1788, ATL.

Fig 62: Claude-Louis Desrais? Homme de l'Isle de Taiti, hand-coloured etching, from P. Sylvain Maréchal, [and Jacques Grasset de Saint-Sauveur] Moeurs et costumes des habitans de l'Isle Taiti, Paris, 1788, ATL.

Fig 63: Habit of a Pict, engraving, from from A collection of the dresses of different nations, antient and modern. Particularly old English dresses, London: Thomas Jefferys, 1757-72, vol. 4, Eighteenth-century collections online, VUW library, 
accessed 4 September 2008 and 20 April 2009. From Gale. Eighteenth Century Collections Online. (C) Gale, a part of Cengage Learning, Inc. Reproduced by permission. www.cengage.com/permissions.

\section{Chapter 5}

Fig 64: Jacques Grasset de Saint-Sauveur and Lachaussee jeune, Habitans de Paris, handcoloured etching, from Grasset de Saint-Sauveur, Paris, 1806, vol. 1, ATL.

Fig 65: Jacques Grasset de Saint-Sauveur and Labrousse, Francais et Francaises, handcoloured etching, from Grasset de Saint-Sauveur, Paris, 1796, vol. 1, ATL.

Fig 66: Jacques Grasset de Saint-Sauveur and Labrousse, Paysan et paysanne des environs de Paris, hand-coloured etching, from Grasset de Saint-Sauveur, Paris, 1796, vol. 1, ATL.

Fig 67: Jacques Grasset de Saint-Sauveur and Labrousse, Anglais et Anglaise, handcoloured etching, from Grasset de Saint-Sauveur, Paris, 1796, vol. 2, ATL.

Fig 68: Jacques Grasset de Saint-Sauveur and Mixelle jeune, Bourgeois \& bourgeoise de Londres hand-coloured etching, from Grasset de Saint-Sauveur, Paris, 1806, vol. 1, ATL.

Fig 69: Jacques Grasset de Saint-Sauveur and Labrousse, Artisanne de Marseille / Artisanne d'Arles, hand-coloured etching, from Grasset de Saint-Sauveur, Paris, 1796, vol. 1, ATL.

Fig 70: Jacques Grasset de Saint-Sauveur and Labrousse, Poissarde de Bordeaux disputant avec un md d'huitres de la tete de Buch [A fish seller disputing with a woman over oysters], hand-coloured etching, from Grasset de Saint-Sauveur, Paris, 1796, vol. 1, ATL.

Fig 71: Jacques Grasset de Saint-Sauveur and Labrousse, Servantes de Strasbourg, handcoloured etching, from Grasset de Saint-Sauveur, Paris, 1796, vol. 1, ATL.

Fig 72: Jacques Grasset de Saint-Sauveur and Labrousse, Habitants de la Guyanne fabricant le rocou, hand-coloured etching, from Grasset de Saint-Sauveur, Paris, 1796, vol. 5, ATL.

Fig 73: Jacques Grasset de Saint-Sauveur and Labrousse, Traiteur Chinois Ambulant, [Chinese mobile caterer], hand-coloured etching, from Grasset de Saint-Sauveur, Paris, 1796, vol. 3, ATL.

Fig 74: Jacques Grasset de Saint-Sauveur and Mixelle jeune, Metayer et berger des Landes de Bordeaux [Tenant farmer and shepherd of the Landes of Bordeaux], handcoloured etching, from Grasset de Saint-Sauveur, Paris, 1806, vol. 1, ATL. 
Fig 75: Jacques Grasset de Saint-Sauveur and Labrousse, Femmes Turque avec leur tanndour [Turkish women (sewing) at their tanndour], hand-coloured etching, from Grasset de Saint-Sauveur, Paris, 1796, vol. 1, ATL.

Fig 76: Jacques Grasset de Saint-Sauveur and Labrousse, Femmes Européennes en habillement Turc [European women in Turkish dress], hand-coloured etching, from Grasset de Saint-Sauveur, Paris, 1796, vol. 1, ATL.

Fig 77: Jacques Grasset de Saint-Sauveur and Labrousse, Derviches fesant la priere, [Dervishes do their prayers], hand-coloured etching, from Grasset de Saint-Sauveur, Paris, 1796, vol. 1, ATL.

Fig 78: Dress of the women of Kamtschatka, engraving, from Charles Middleton, A new and complete system of geography containing a full, accurate, authentic and interesting account and description of Europe, Asia, Africa and America ... including the essence of all the most remarkable voyages and travels ..., London: $\mathrm{J}$ Cooke, 17 Paternoster Row, 1777, vol. 1, fp. 44, ATL.

Fig 79: Jacques Grasset de Saint-Sauveur and J. Laroque, Homme de Kamtschatka, handcoloured etching, from Grasset de Saint-Sauveur, Paris, 1796, vol. 3, ATL.

Fig 80: The winter habitations of the peasants of Kamtschatka and The summer habitations of the superior people of Kamtschatka, from Rev. Thomas Bankes, New, royal and authentic system of universal geography...Europe, Asia, Africa and America... [and] collection of voyages and travels, London: C. Cooke, 17 Paternoster Row; 1790, engravings after Webber, no names on print, Vol. 1, fp. 117, ATL.

Fig 81: Jacques Grasset de Saint-Sauveur and J. Laroque, Femme de Kamtschatka, handcoloured etching, from Grasset de Saint-Sauveur, Paris, 1796, vol. 3, ATL.

Fig 82: Jacques Grasset de Saint-Sauveur and J. Laroque, Femme Kamtschadale, handcoloured etching, from Grasset de Saint-Sauveur, Paris, 1796, vol. 3, ATL.

Fig 83: Jacques Grasset de Saint-Sauveur and J. Laroque, Negre Namaquas, hand-coloured etching, from Grasset de Saint-Sauveur, Paris, 1796, vol. 4, ATL.

Fig 84: Jacques Grasset de Saint-Sauveur and J. Laroque, Negresse Namaquas, handcoloured etching, from Grasset de Saint-Sauveur, Paris, 1796, vol. 4, ATL.

Fig 85: White (Charles William?), Hottentot men women and children, engraving, from Charles Middleton, A new and complete system of geography containing a full, accurate, authentic and interesting account and description of Europe, Asia, Africa and America ... including the essence of all the most remarkable voyages and travels ..., London: J. Cooke, 17 Paternoster Row, 1777, vol. 1, fp. 377, ATL. 
Fig 86: Jacques Grasset de Saint-Sauveur and J. Laroque, Hottentot, hand-coloured etching, from Grasset de Saint-Sauveur, Paris, 1796, vol. 4, ATL.

Fig 87: Jacques Grasset de Saint-Sauveur and J. Laroque, Hottentote [Hottentot woman], hand-coloured etching, from Grasset de Saint-Sauveur, Paris, 1796, vol. 4, ATL.

Fig 88: Jacques Grasset de Saint-Sauveur and Lachaussee jeune, Homme et femme Hottentot, hand-coloured etching, from Grasset de Saint-Sauveur, Paris, 1806, vol. 2, ATL.

Fig 89: Conder, Jaggas \& their manner of fighting, engraving, from George Millar, The new and universal system of geography: being a complete history and description of the whole world ..., London: Alexander Hogg, 16 Paternoster Row, 1782, fp. 301, ATL.

Fig 90: Jacques Grasset de Saint-Sauveur and Labrousse, Negre Anzikos armé en guerre, hand-coloured etching, from Grasset de Saint-Sauveur, Paris, 1796, vol. 4, ATL.

Fig 91: Jacques Grasset de Saint-Sauveur and Labrousse, Homme et femme de qualité le Jaggas, hand-coloured etching, from Grasset de Saint-Sauveur, Paris, 1806, vol. 2, ATL.

Fig 92: Jacques Grasset de Saint-Sauveur and Labrousse, Negre de la côte des Graines, hand-coloured etching, from Grasset de Saint-Sauveur, Paris, 1796, vol. 4, ATL.

Fig 93: Jacques Grasset de Saint-Sauveur and Lachausée jeune, Homme et femme Jaggaa, hand-coloured etching, from Grasset de Saint-Sauveur, Paris, 1806, vol. 2, ATL.

Fig 94: Jacques Grasset de Saint-Sauveur and Lachausée jeune, Homme et femme Anzikos, hand-coloured etching, from Grasset de Saint-Sauveur, Paris, 1806, vol. 2, ATL.

Fig 95: Jacques Grasset de Saint-Sauveur and Labrousse, Guerrier Iroquois, hand-coloured etching, from Grasset de Saint-Sauveur, Paris, 1796, vol. 5, ATL.

Fig 96: Jacques Grasset de Saint-Sauveur and J. Laroque, Iroquois allant a la Découverte [Iroquois going off on a search], hand-coloured etching, from Grasset de SaintSauveur, Paris, 1796, vol. 5, ATL.

Fig 97: Jacques Grasset de Saint-Sauveur and J. Laroque, Grand Chef de Guerriers Iroquois, hand-coloured etching, from Grasset de Saint-Sauveur, Paris, 1796, vol. 5, ATL.

Fig 98: A man of California..., engraving, from Charles Middleton, A new and complete system of geography containing a full, accurate, authentic and interesting account and description of Europe, Asia, Africa and America ... including the essence of all the most remarkable voyages and travels ..., London: J. Cooke, 17 Paternoster Row, 1777, vol. 2, fp. 492, ATL. 
Fig 99: Jacques Grasset de Saint-Sauveur and Labrousse, Homme de la Californie, handcoloured etching, from Grasset de Saint-Sauveur, Paris, 1796, vol. 5, ATL.

Fig 100: Jacques Grasset de Saint-Sauveur and Lachausée jeune, Homme et femme de Californie, hand-coloured etching, from Grasset de Saint-Sauveur, Paris, 1806, vol. 2, ATL.

Fig 101: Jacques Grasset de Saint-Sauveur and Lachausée jeune, Homme et femme des isles Marquises, hand-coloured etching, from Grasset de Saint-Sauveur, Paris, 1806, vol. 2, ATL.

Fig 102: Jacques Grasset de Saint-Sauveur and Lachausée jeune, Homme et femme de la Catalogne dansant le fandago, hand-coloured etching, from Grasset de SaintSauveur, Paris, 1806, vol. 1, ATL.

Fig 103: The tarantula with the method of curing those stung by it, which is effected by music and dancing, engraving, from Charles Middleton, $A$ new and complete system of geography containing a full, accurate, authentic and interesting account and description of Europe, Asia, Africa and America ... including the essence of all the most remarkable voyages and travels ..., London: J. Cooke, 17 Paternoster Row, 1777, vol. 2, fp. 392, ATL.

Fig 104: Hawkins, Hottentot entertainment of music and dancing, engraving, from Thomas Bankes, New, royal and authentic system of universal geography ... Europe, Asia, Africa and America ... [and] collection of voyages and travels, London: C. Cooke, 17 Paternoster Row; 1790, fp. 318, ATL.

Fig 105: Jacques Grasset de Saint-Sauveur and J. Laroque, Sauvage de la Terre de Natal, hand-coloured etching, from Grasset de Saint-Sauveur, Paris, 1796, vol. 4, ATL. 
Illustrations (refer to list for titles)

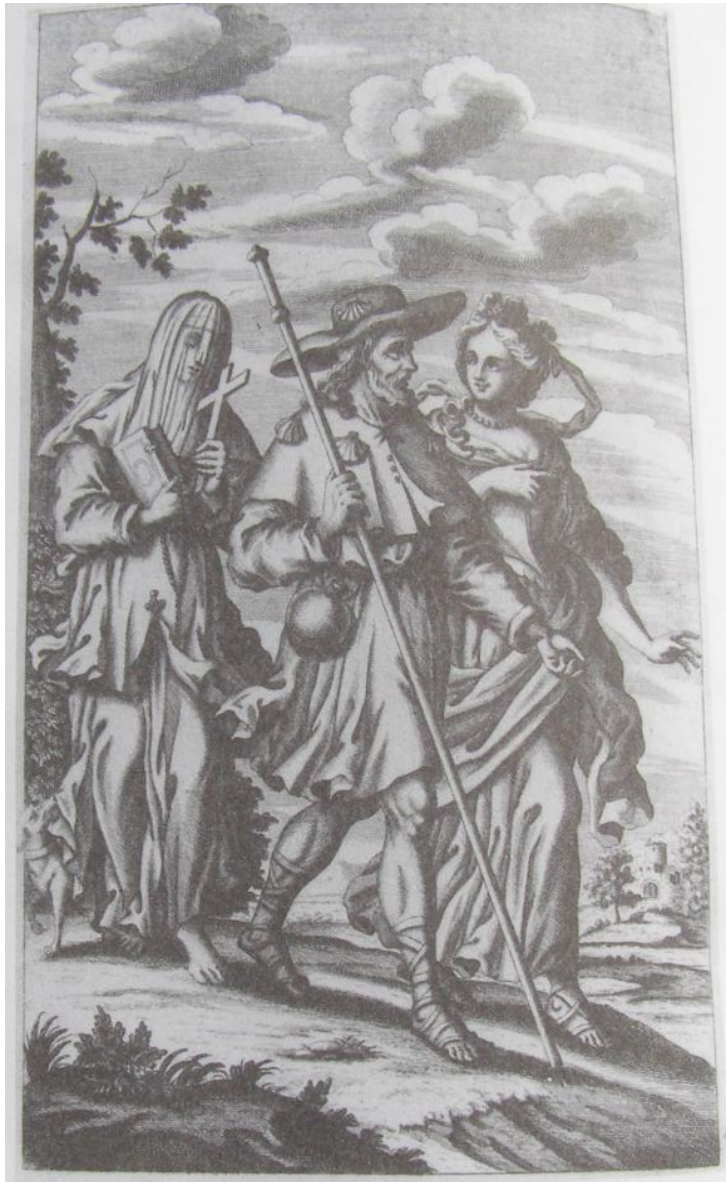

Fig 1

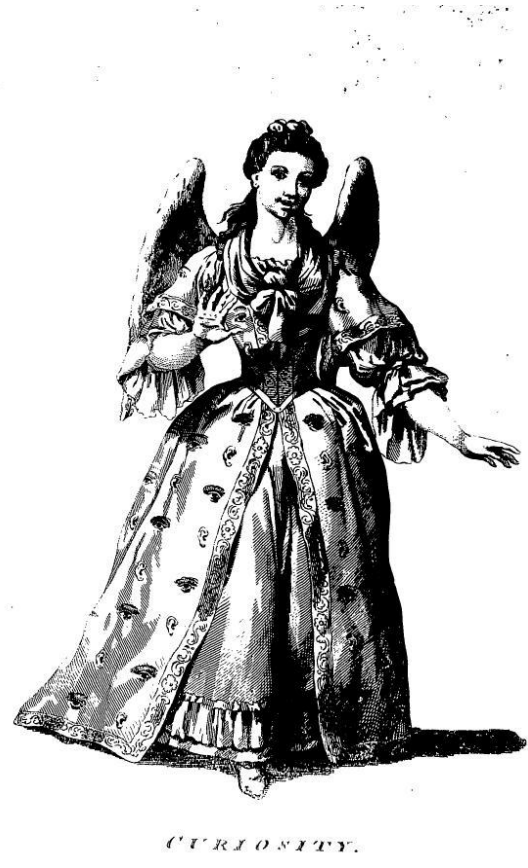

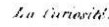

Fig 2 


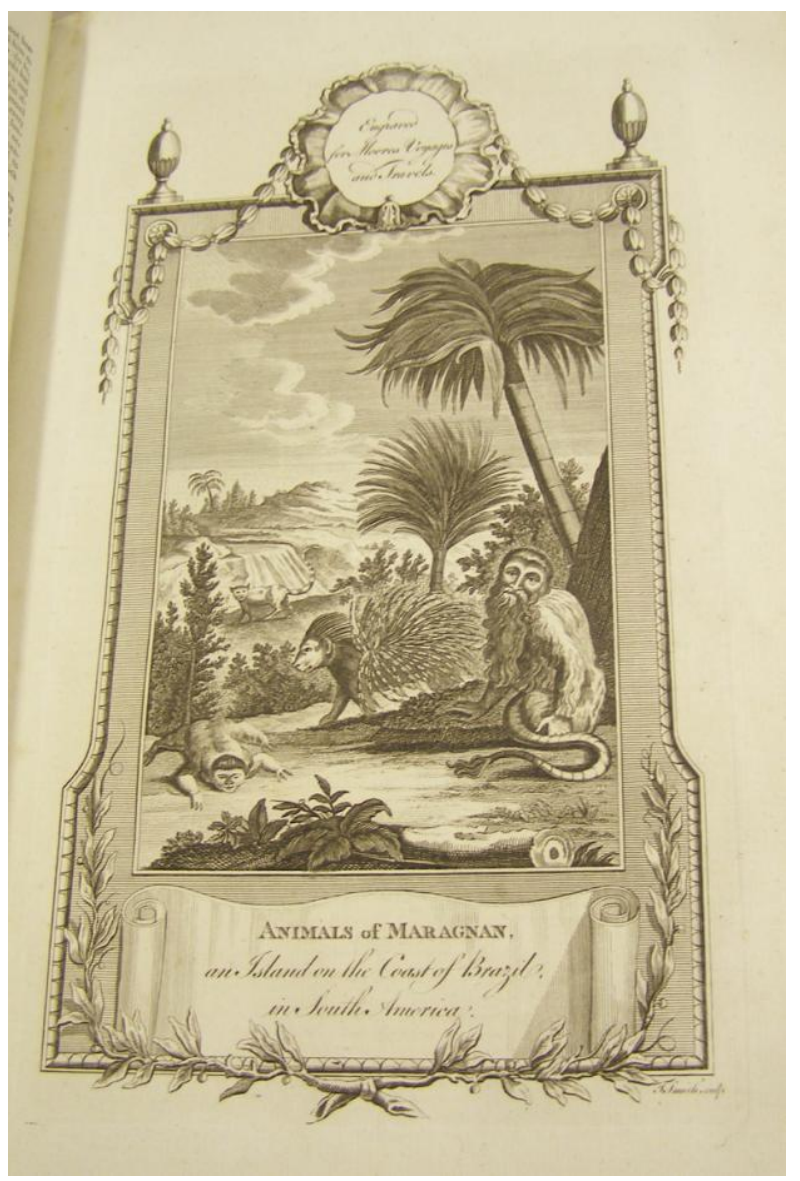

Fig 3

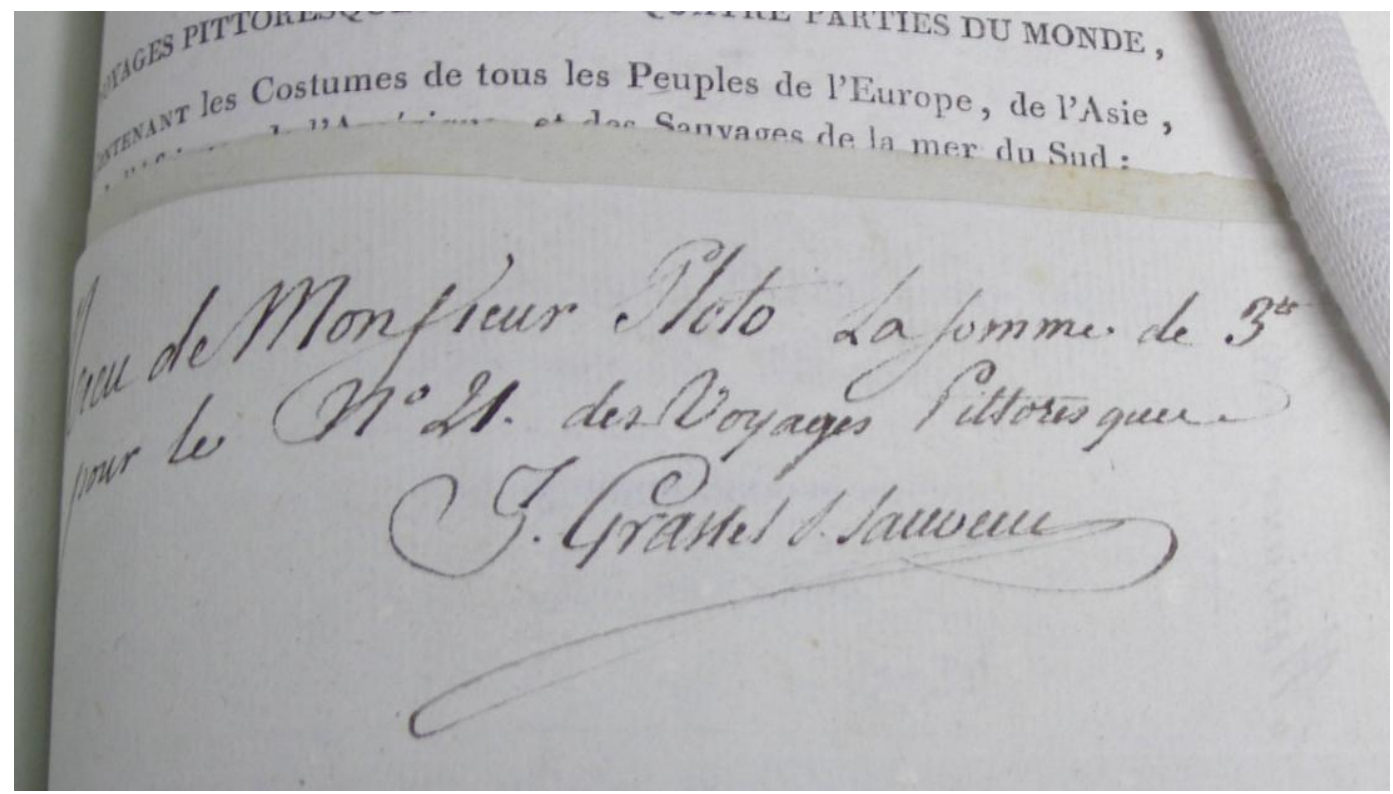

Fig 4 


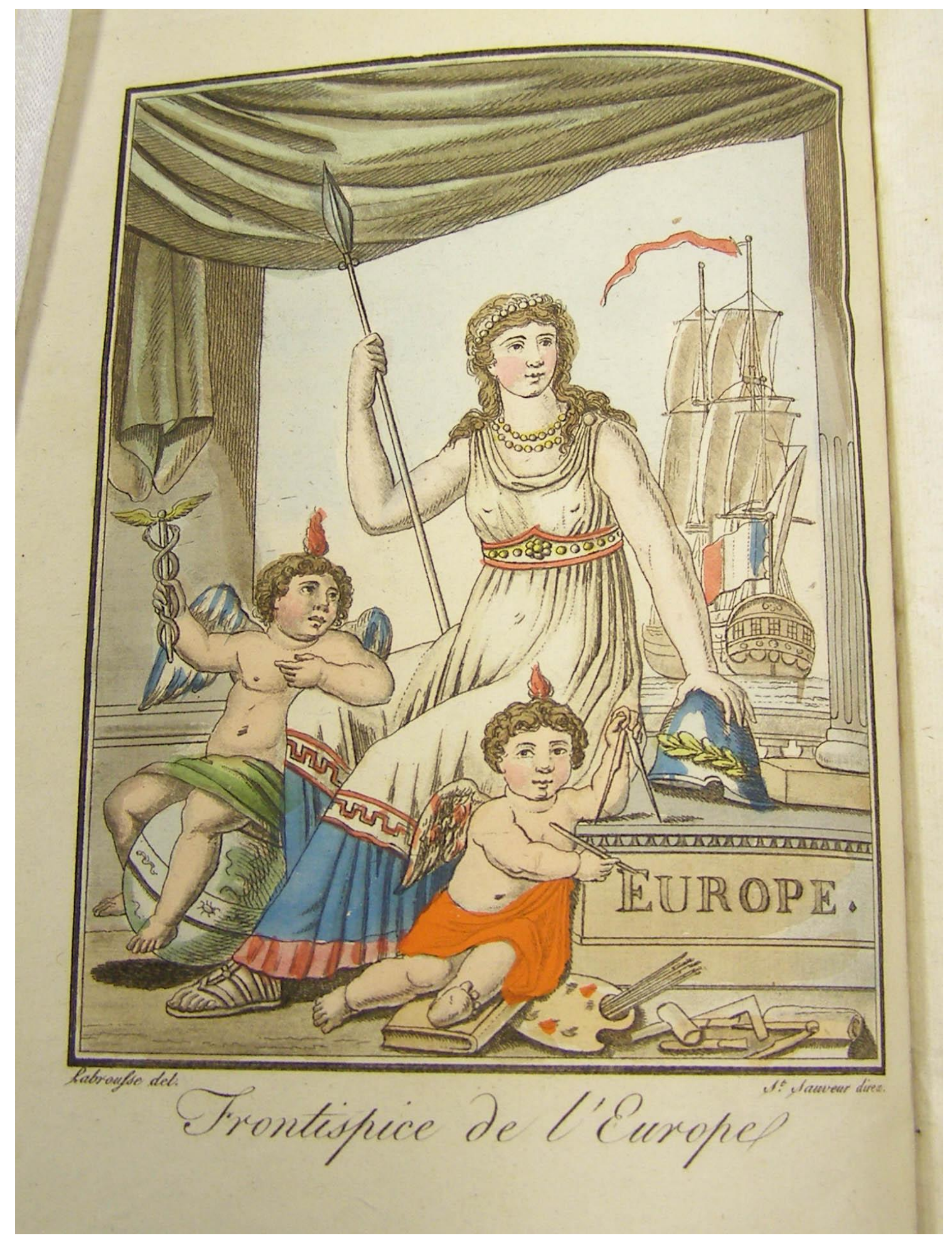

Fig 5 


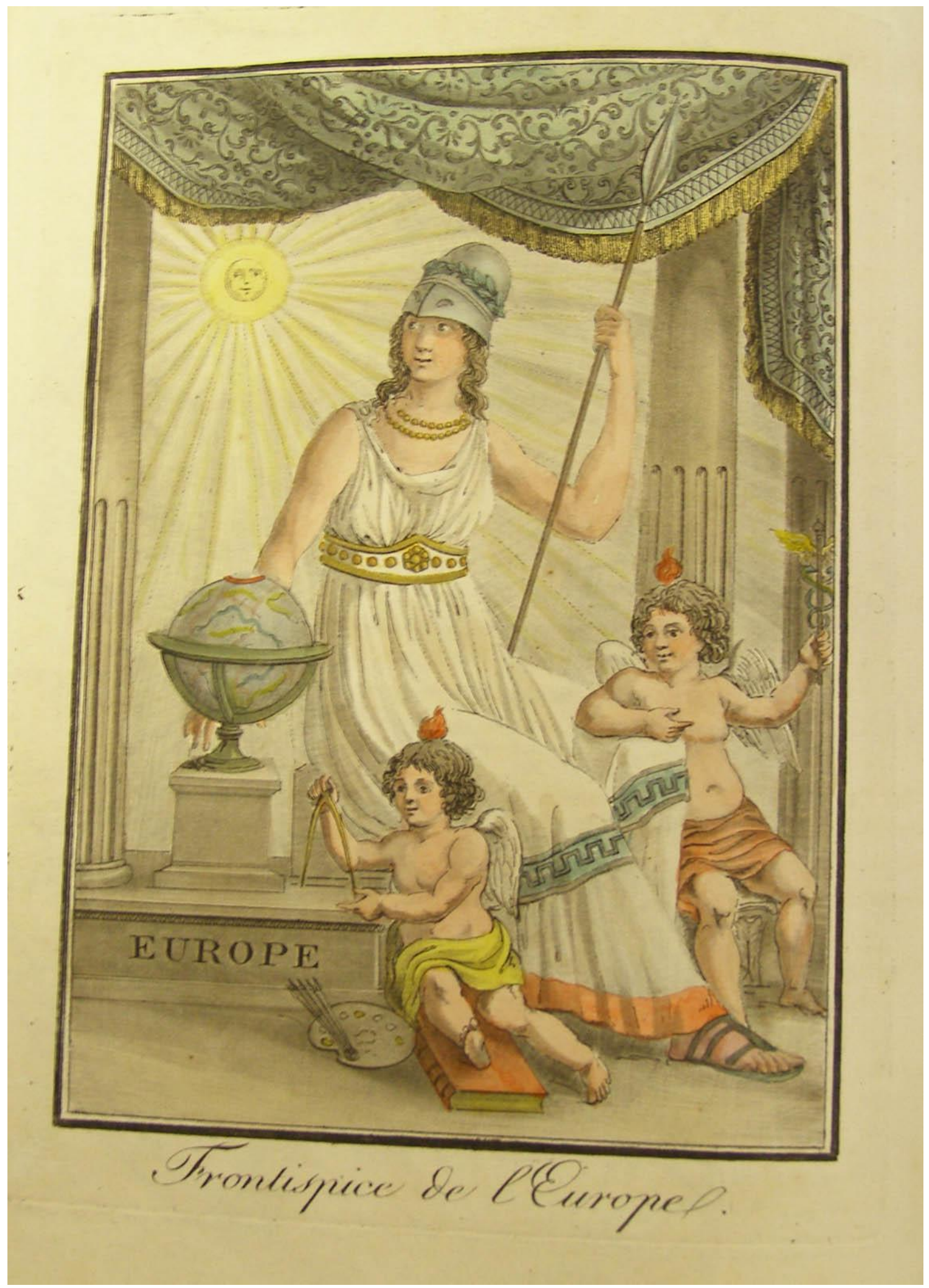

Fig 6 


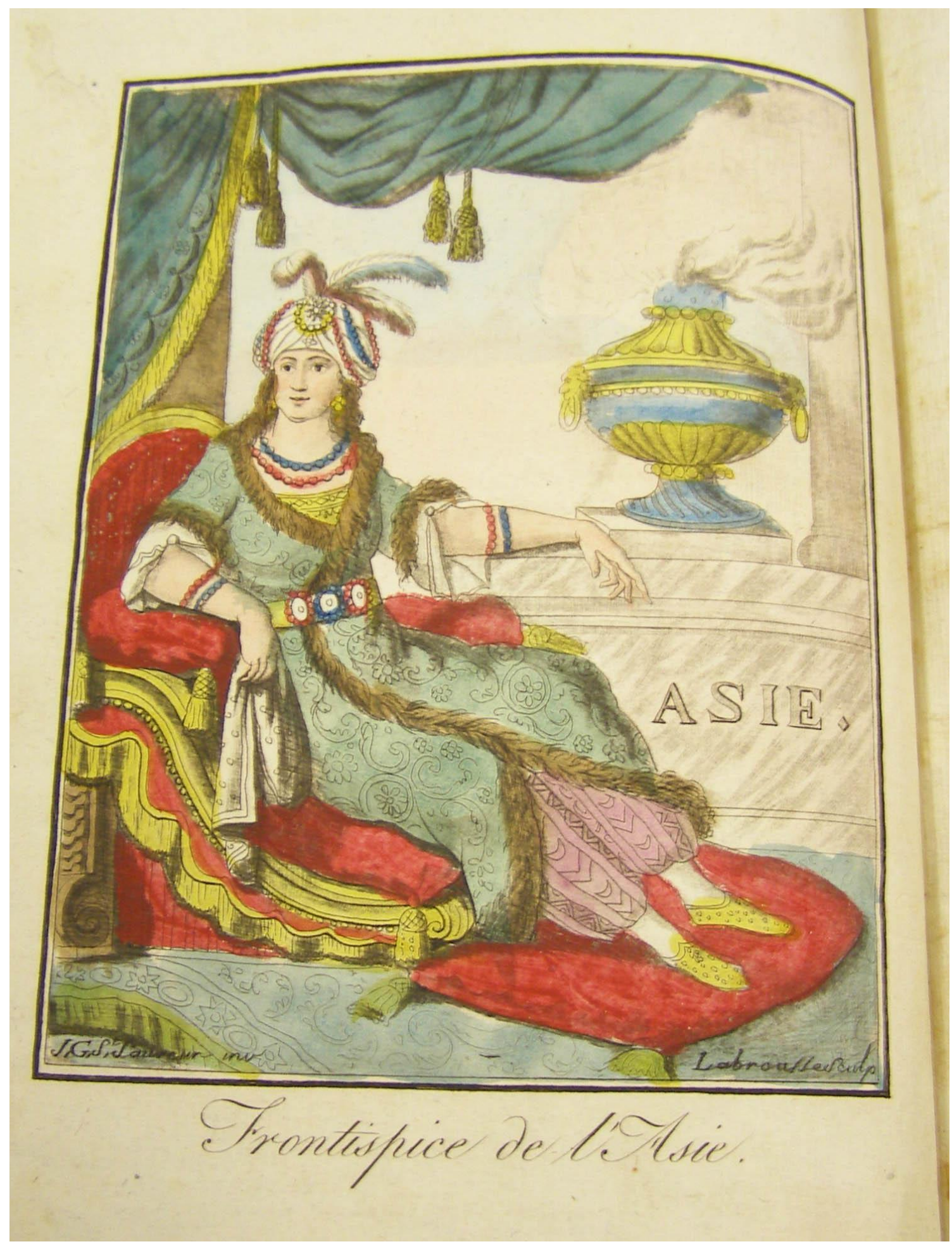

Fig 7 


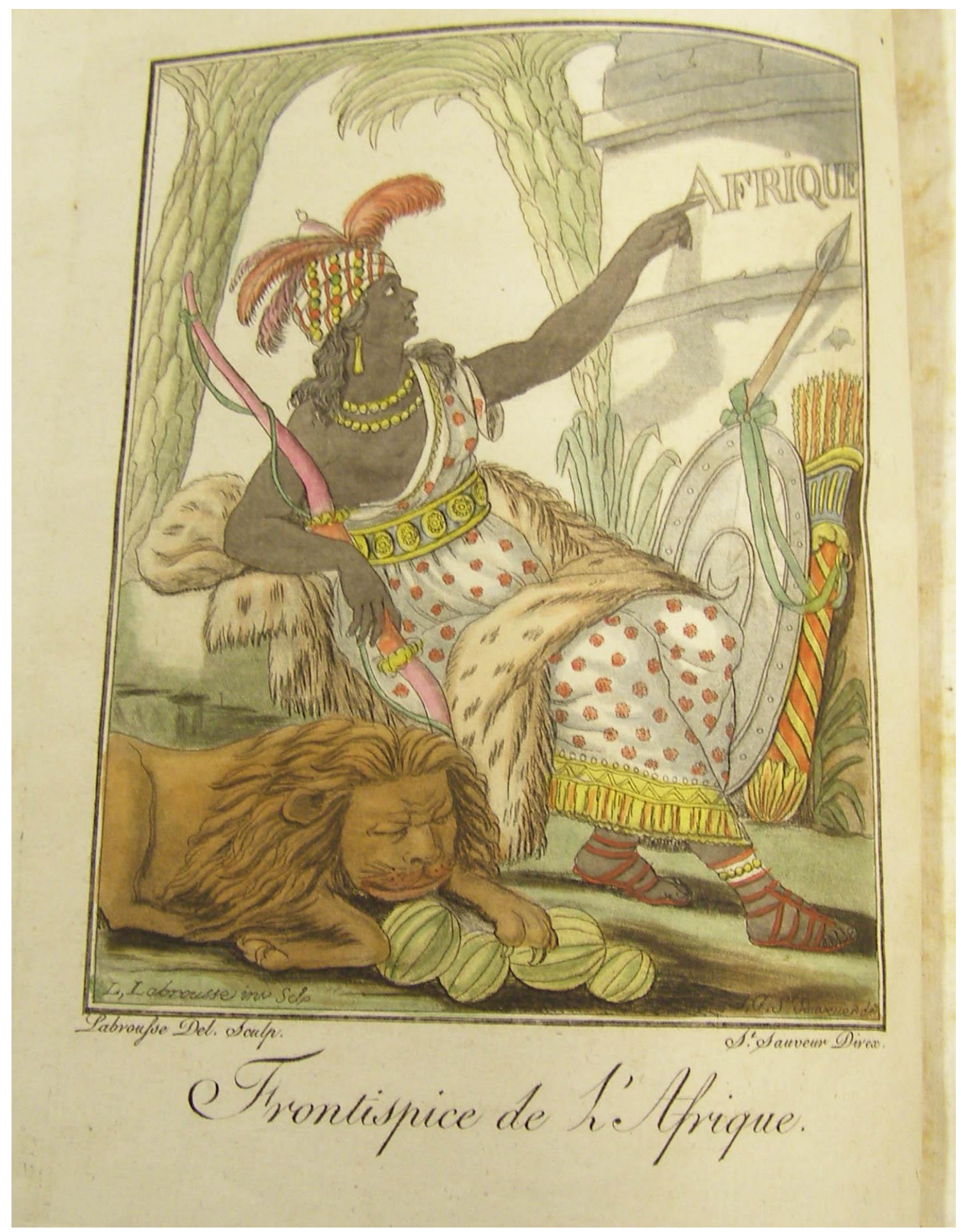

Fig 8 


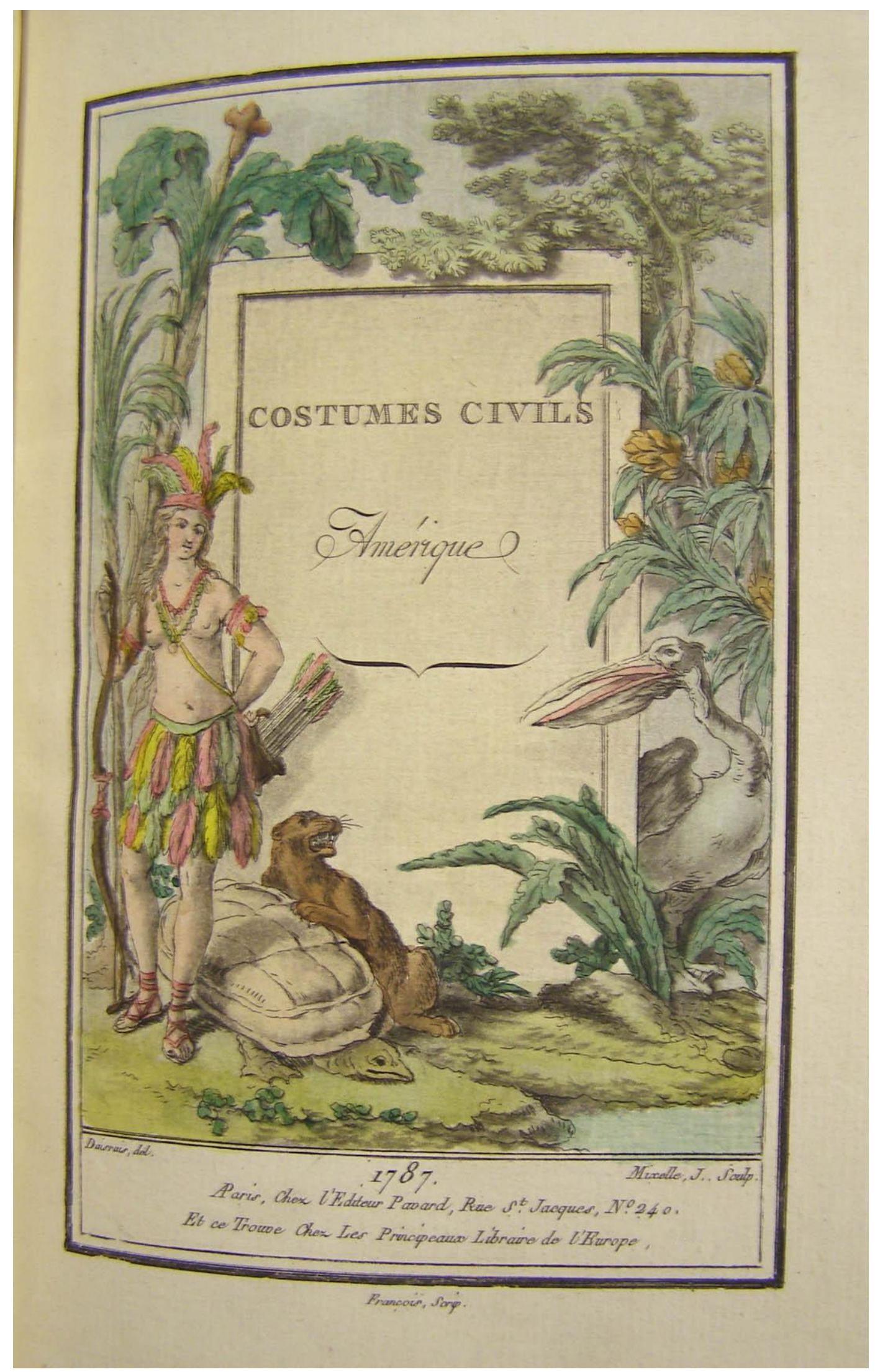

Fig 9 


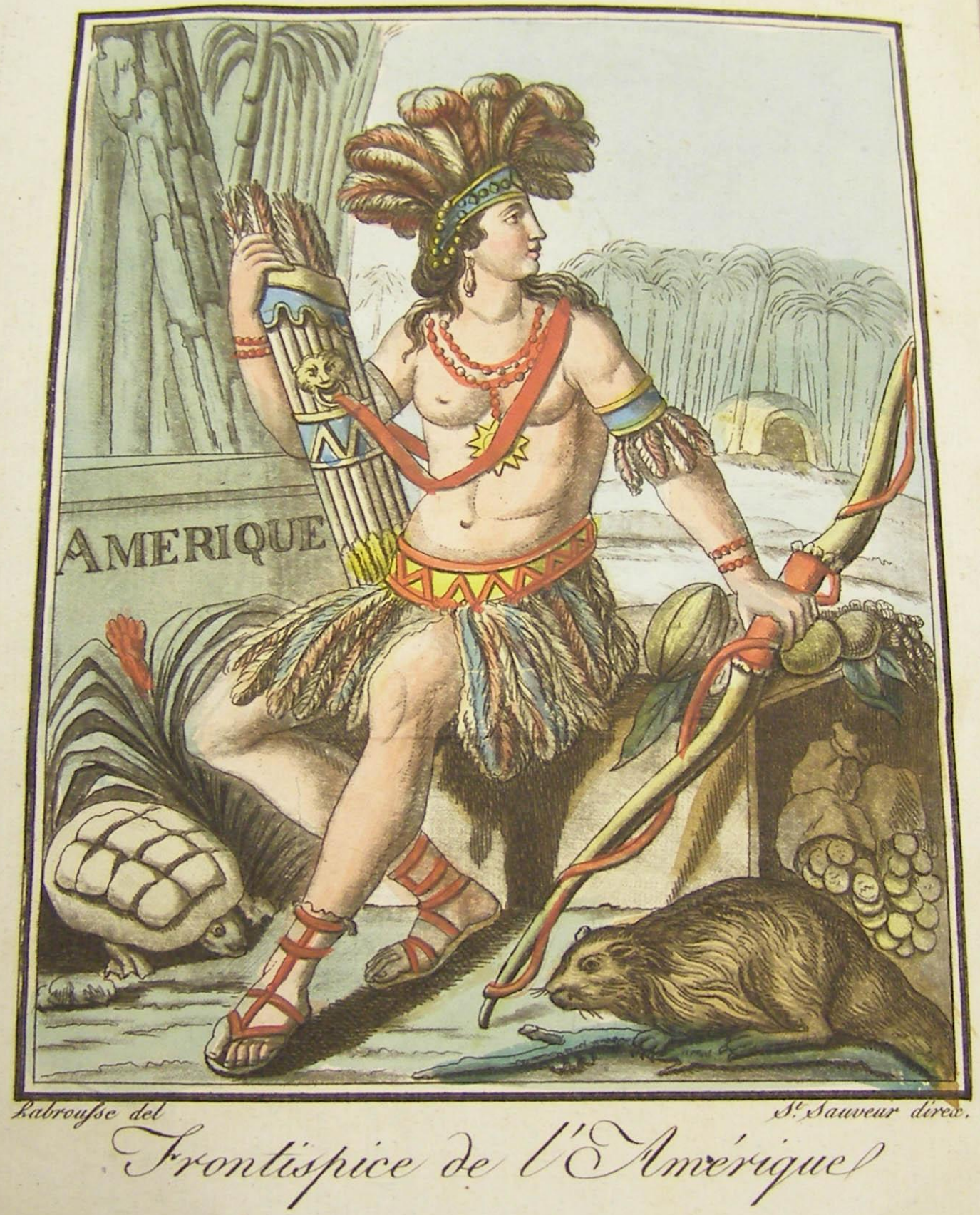

Fig 10 


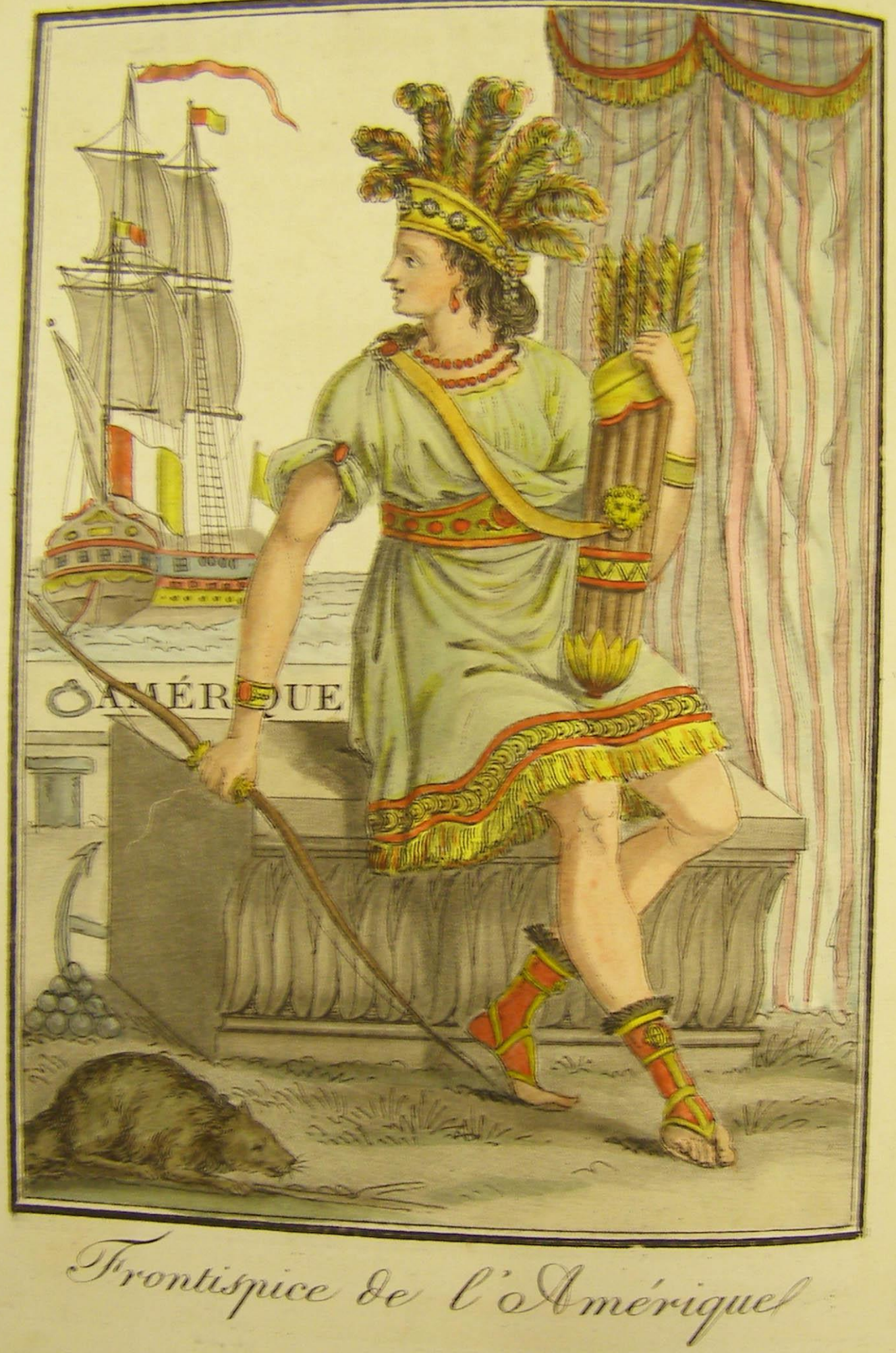

Fig 11 
Amer. Mer.

L'Au 1806.

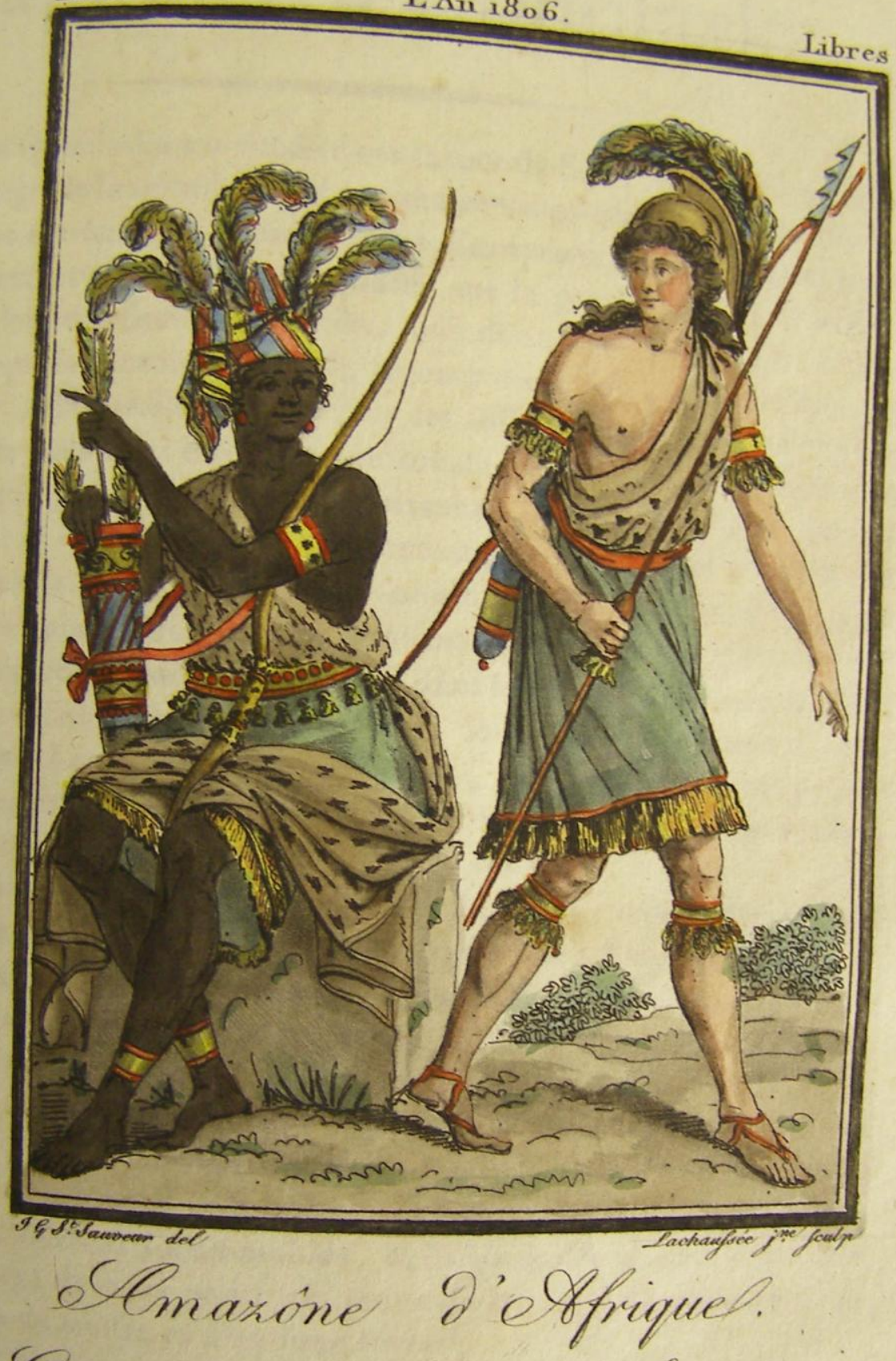

Gueviere de la miviore des etmanónes.

Fig 12 


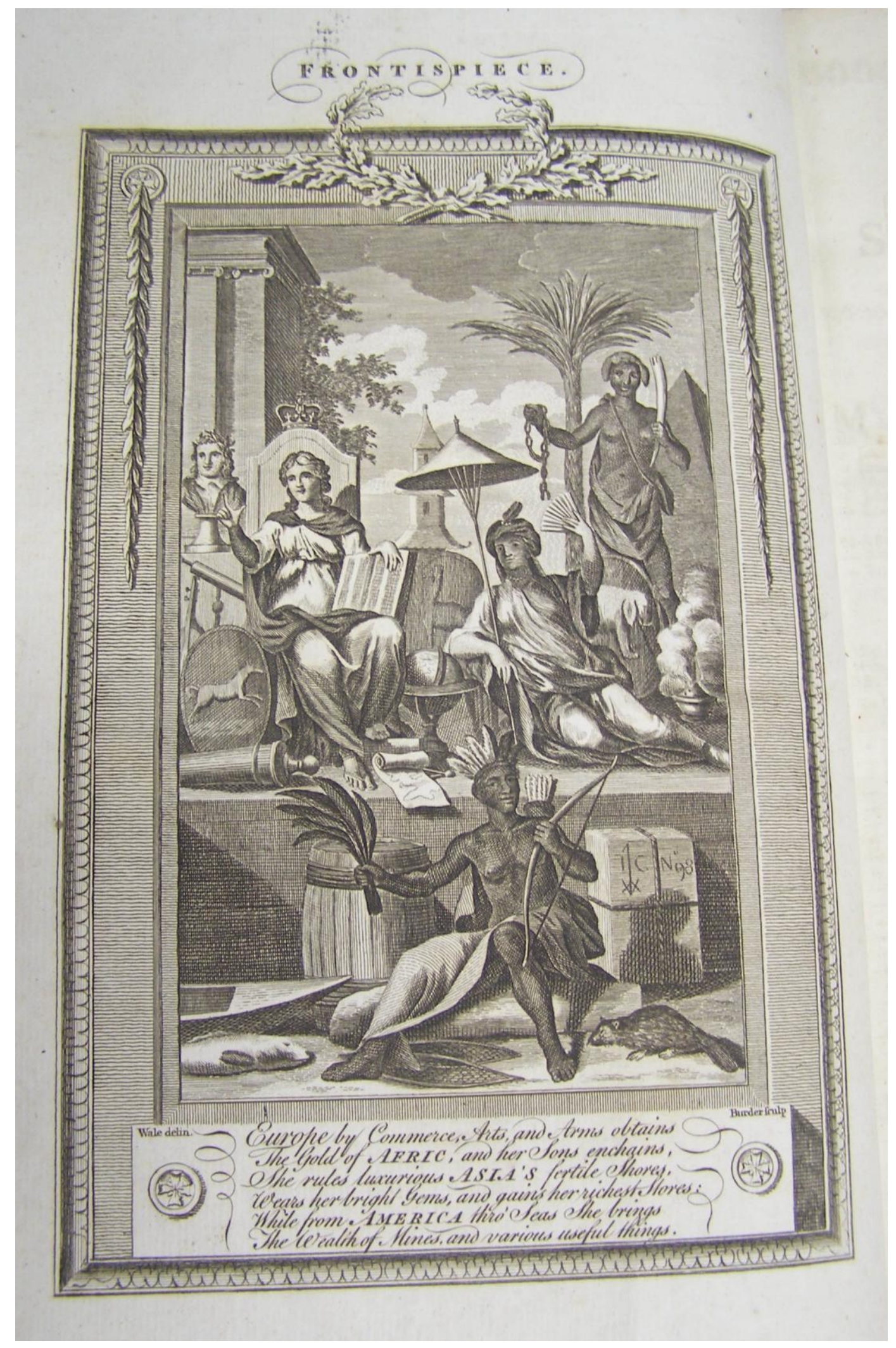

Fig 13 


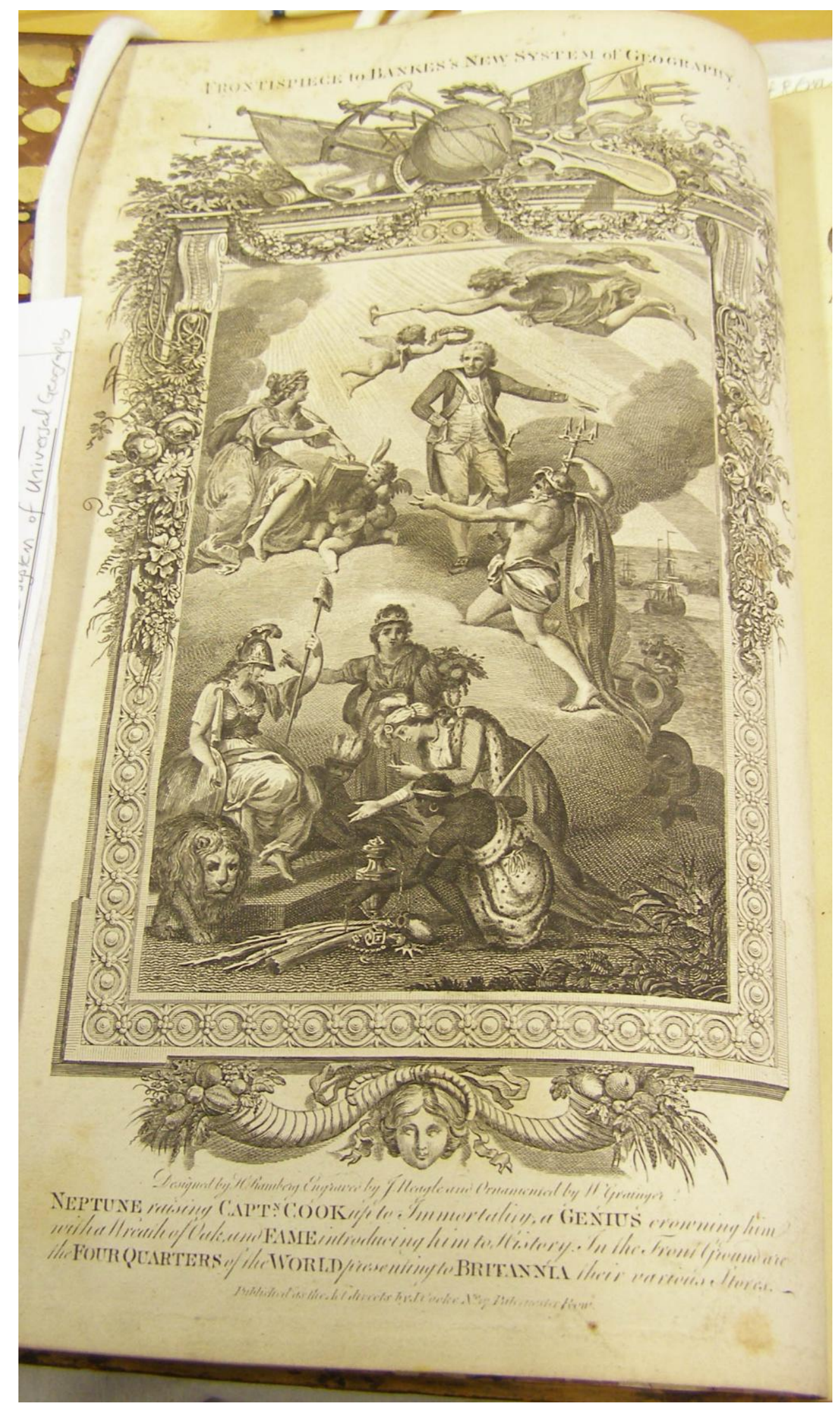

Fig 14 


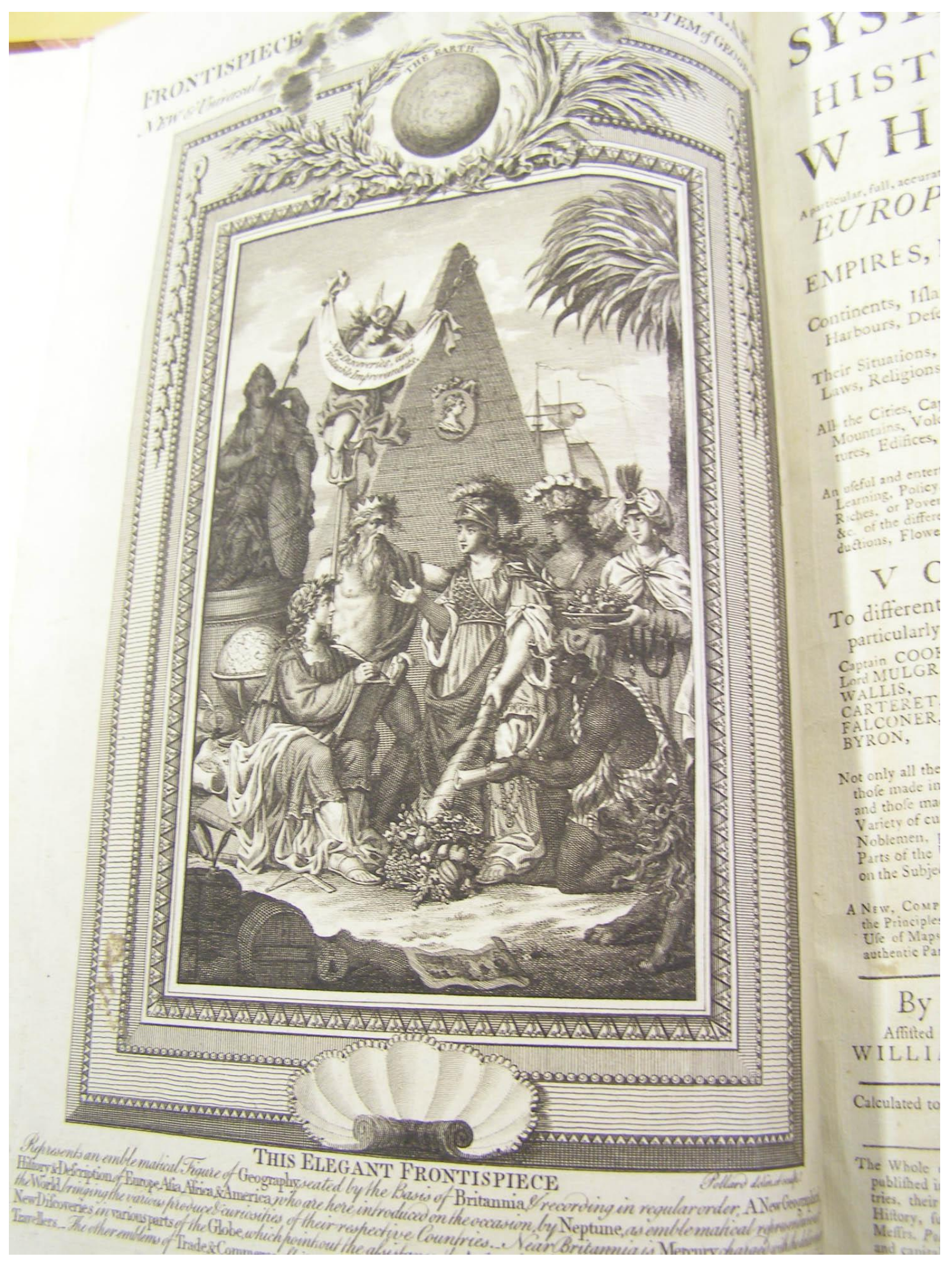

Fig 15 


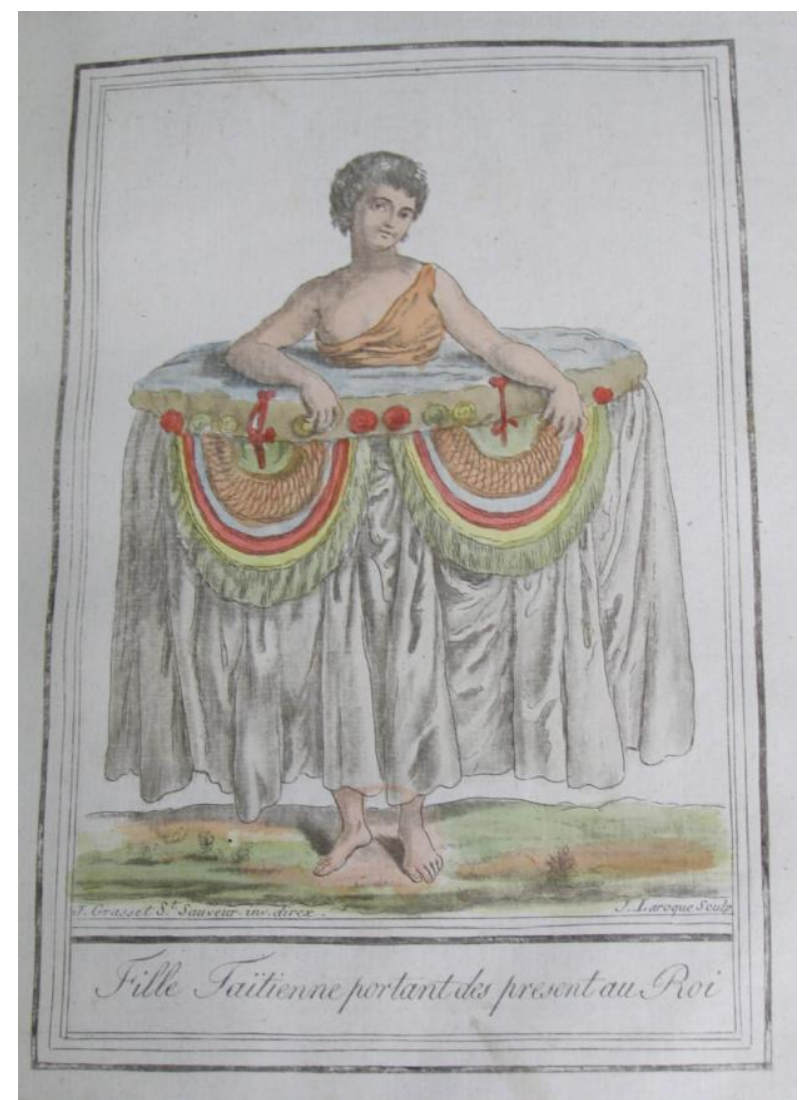

Fig 16

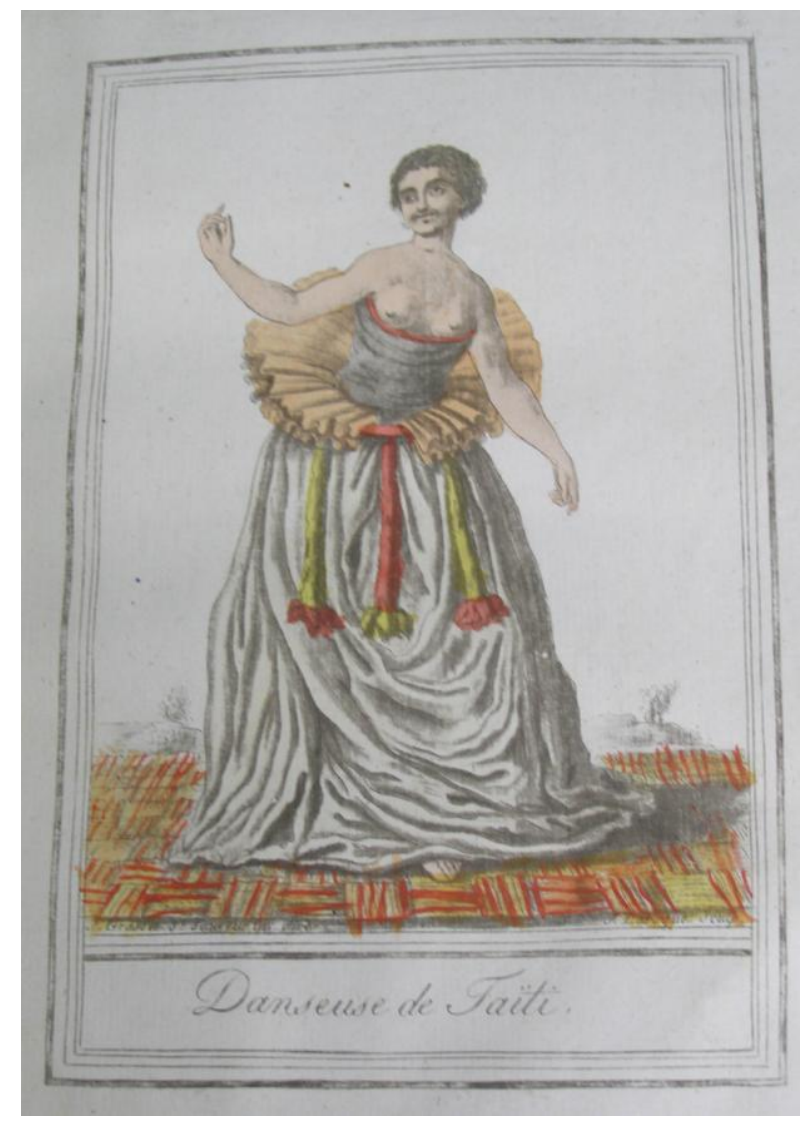

Fig 17 


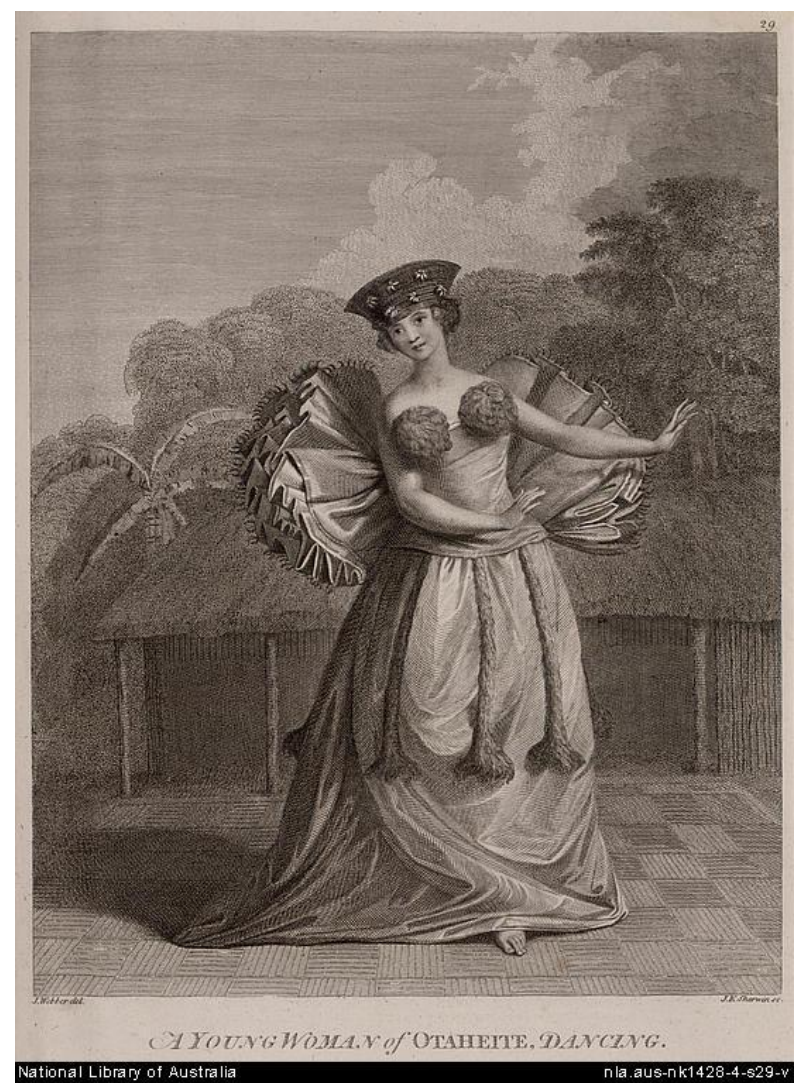

Fig 18

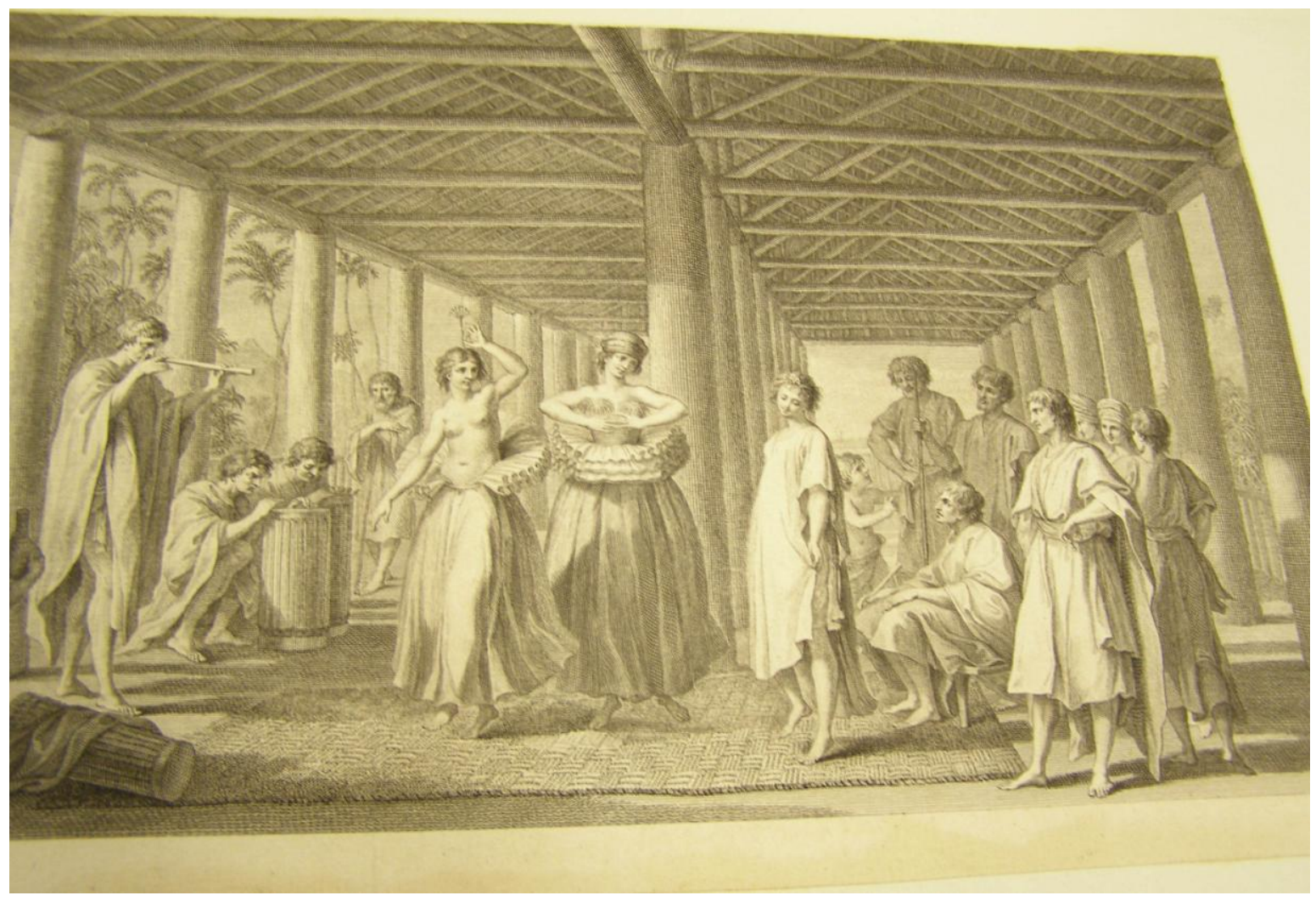

Fig 19 


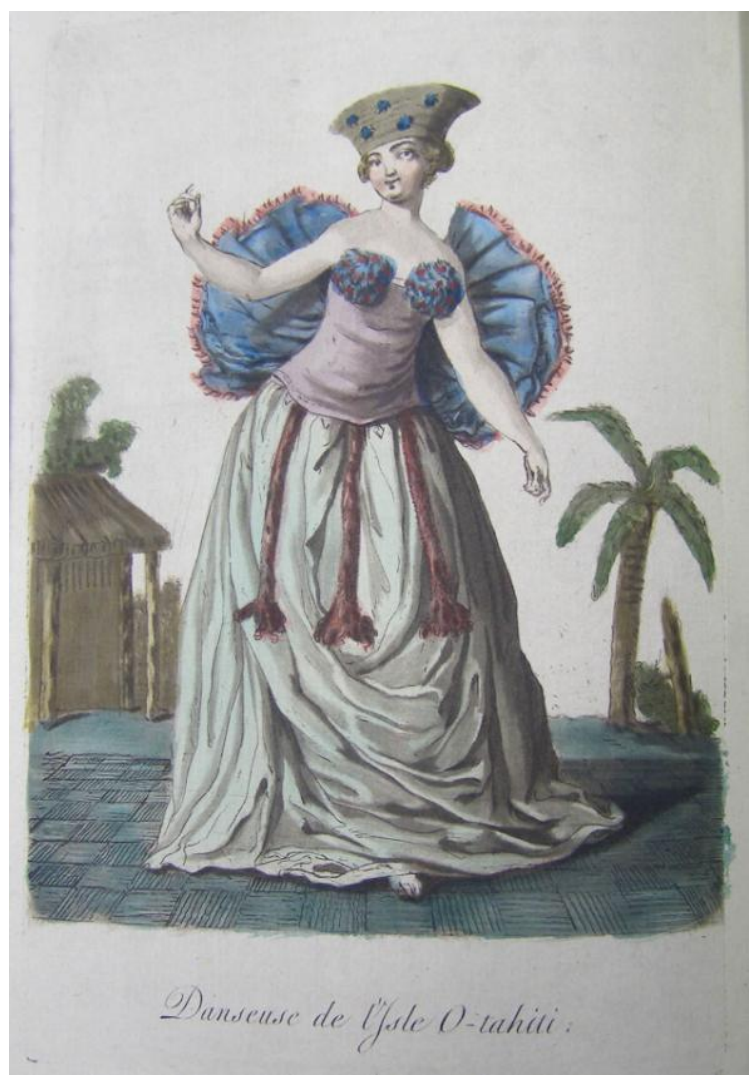

Fig 20

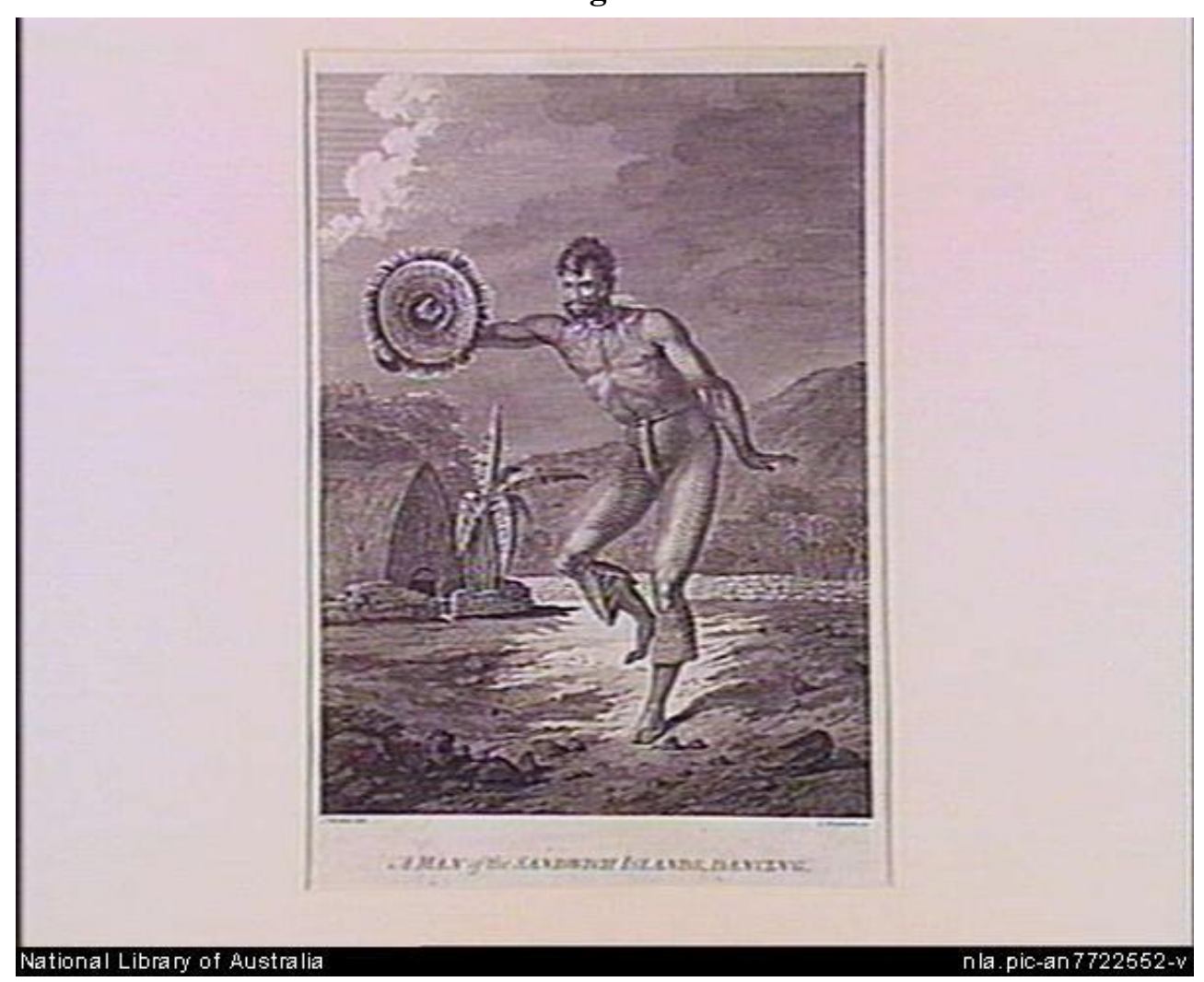

Fig 21 


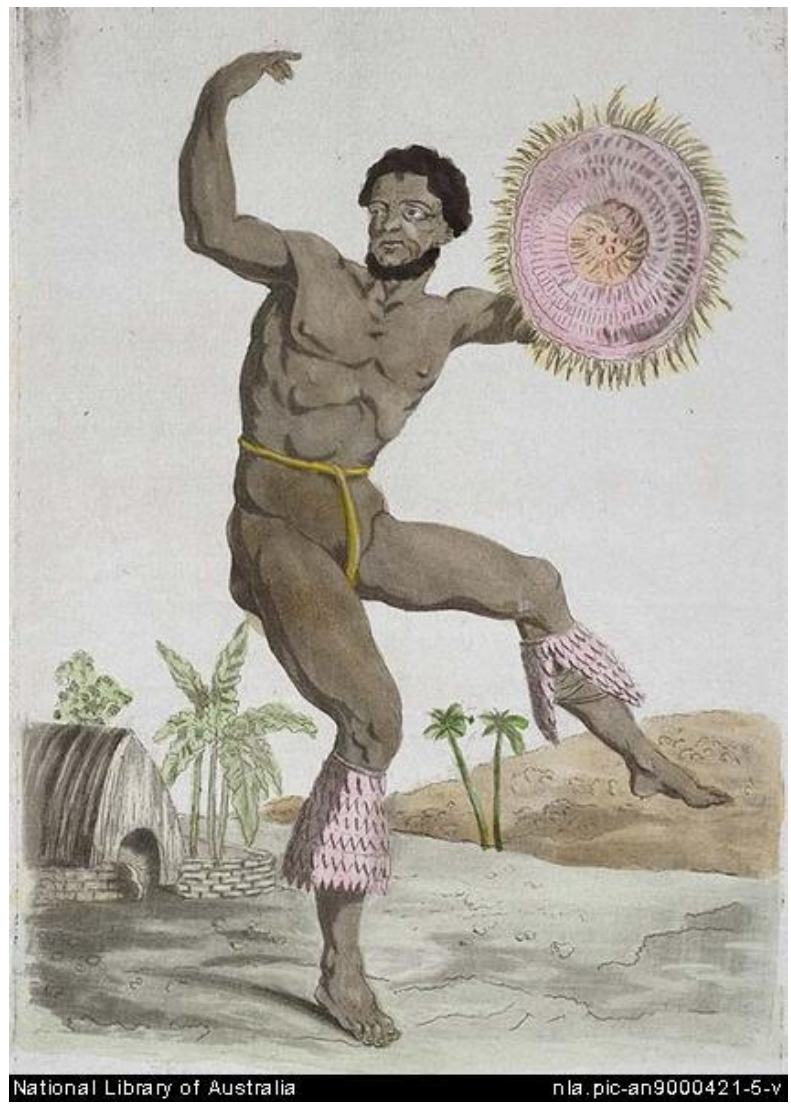

Fig 22

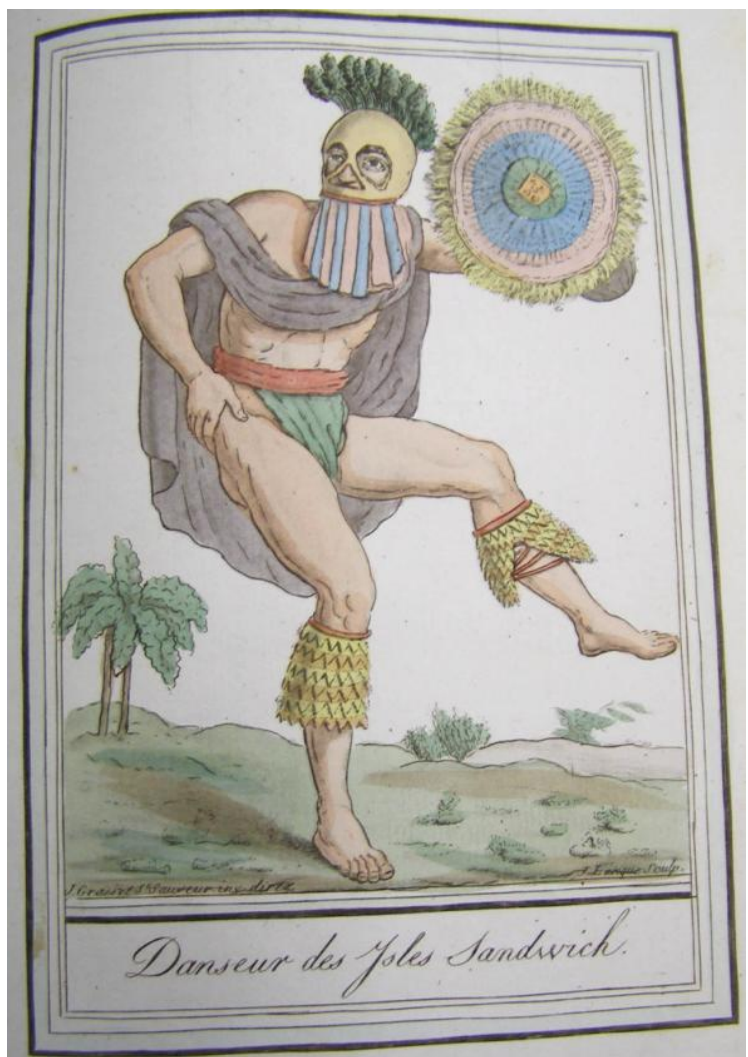

Fig 23 


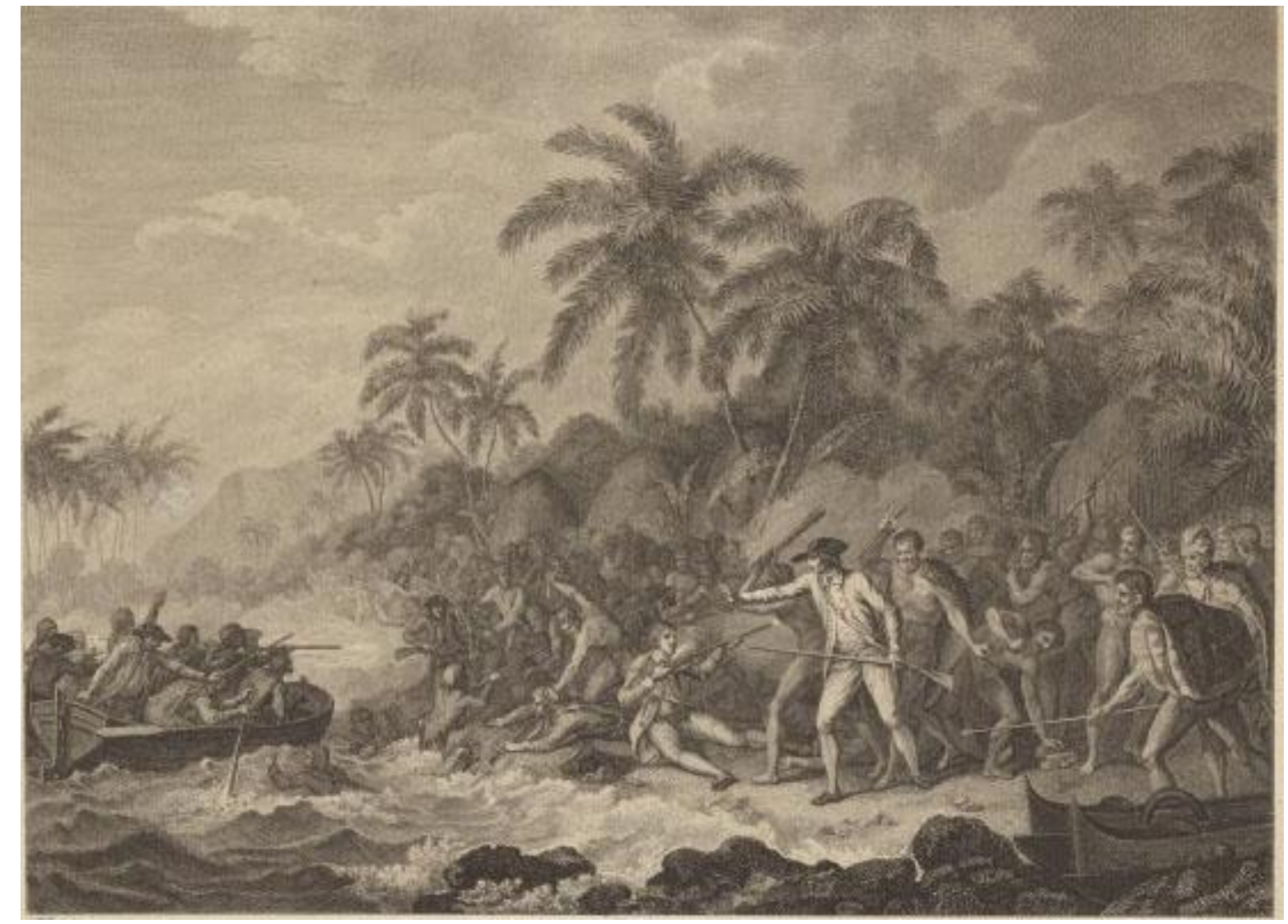

Fig 24

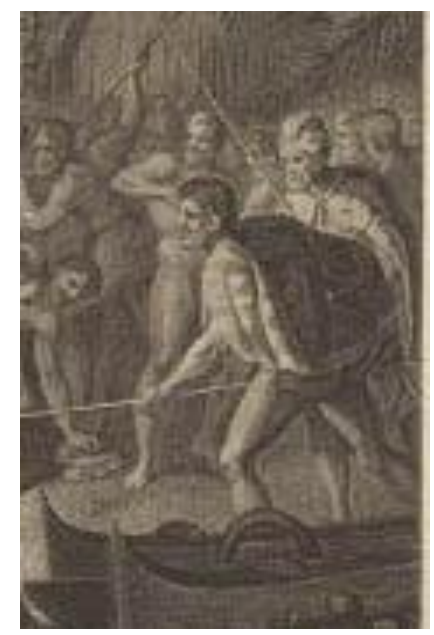

Fig 24 - detail 


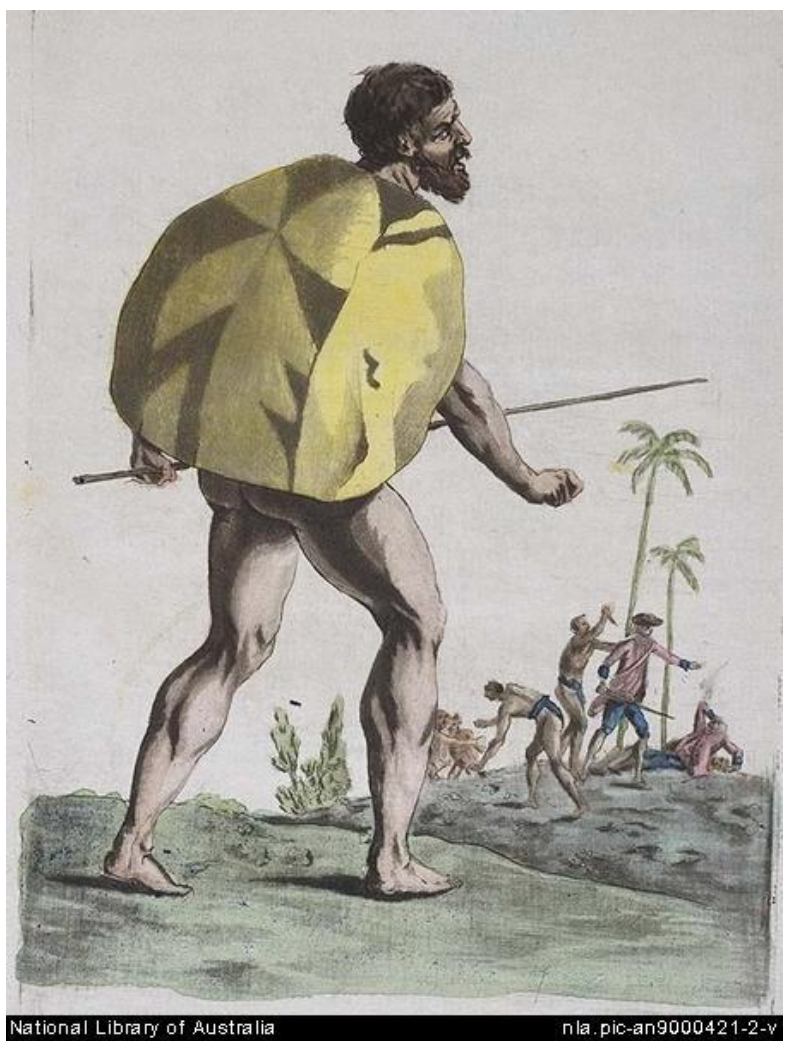

Fig 25

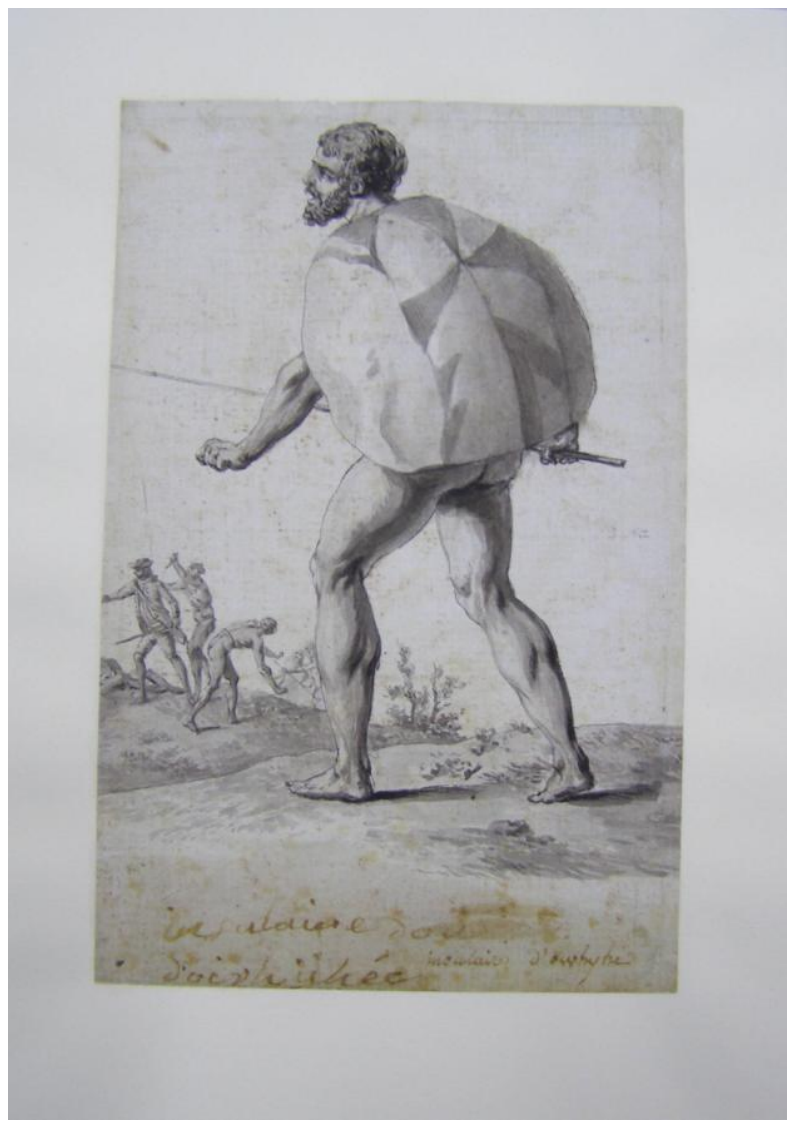

Fig 26 


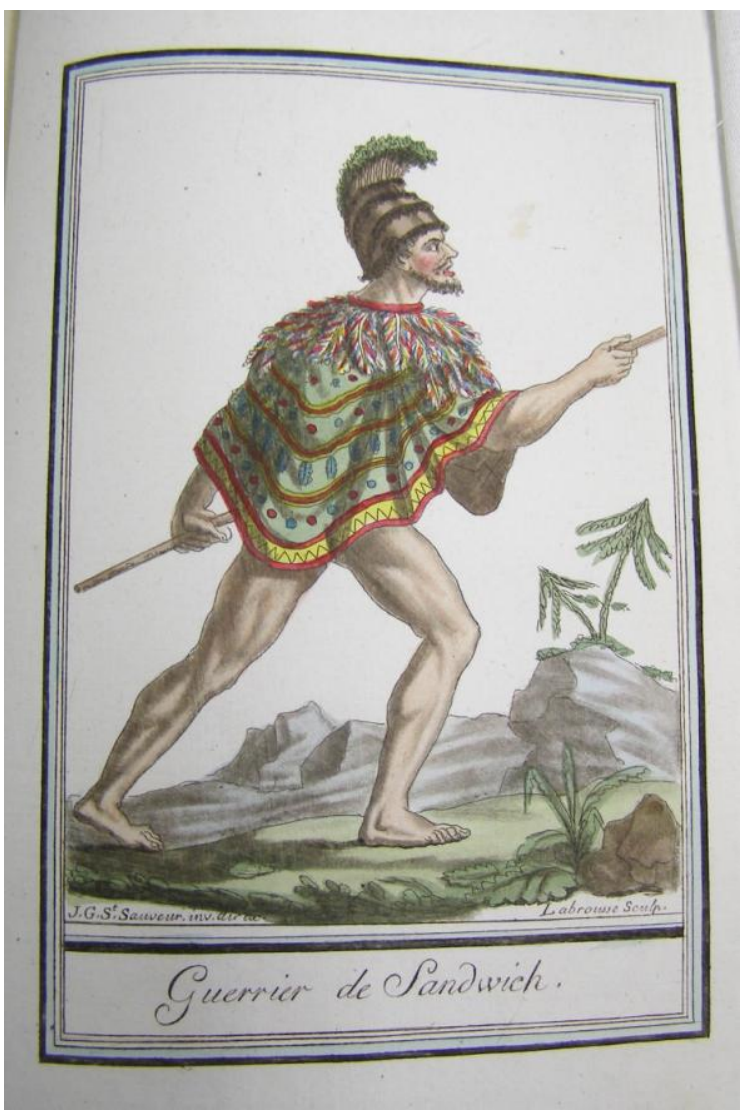

Fig 27

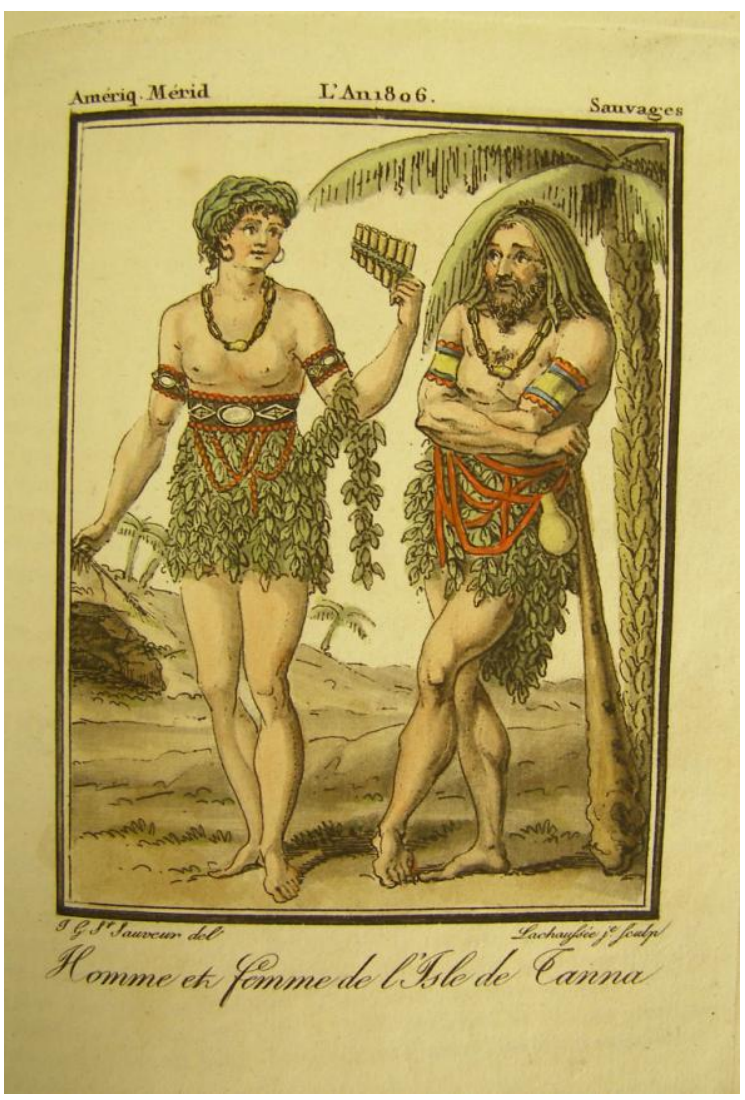

Fig 28 


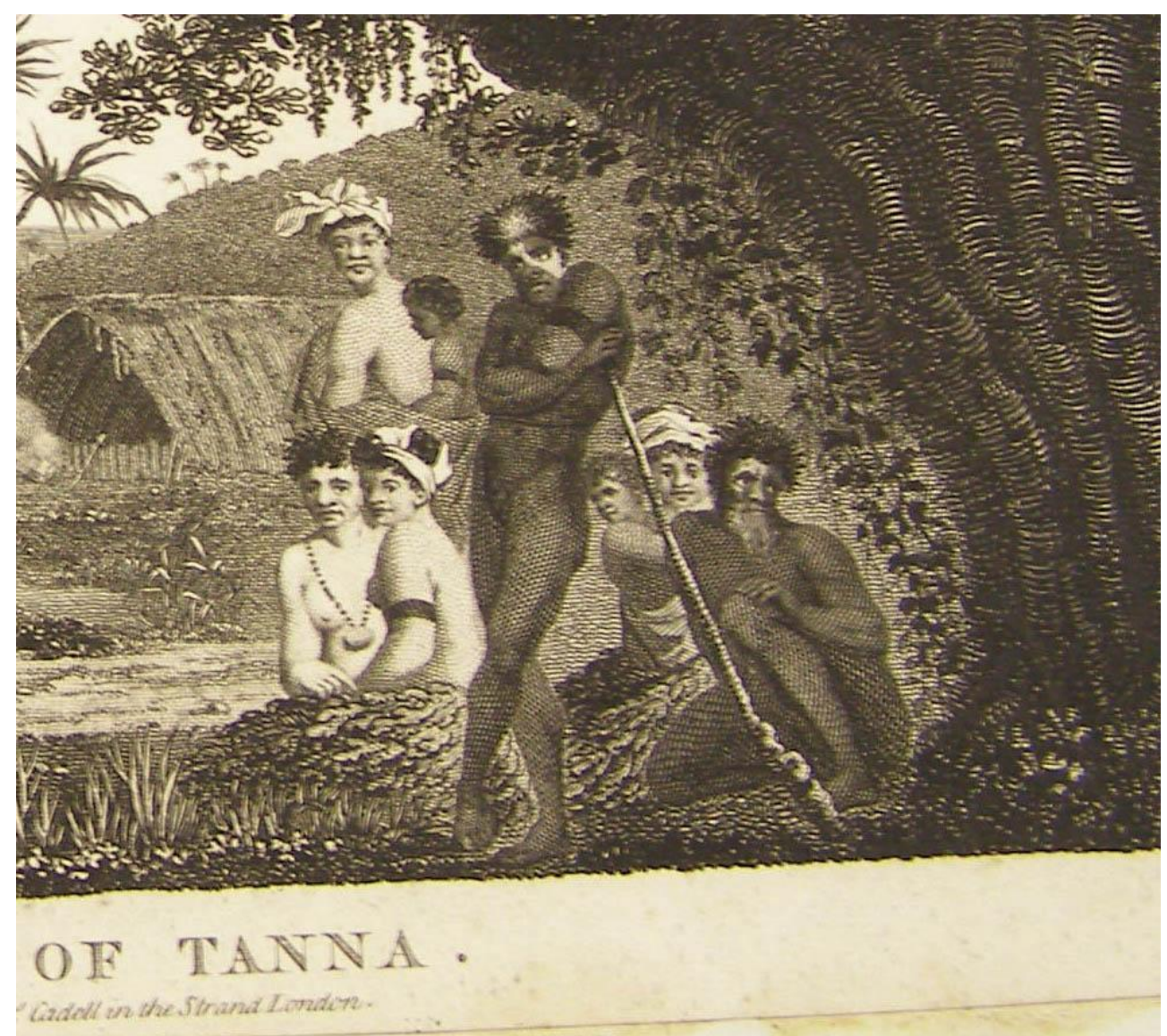

Fig 29

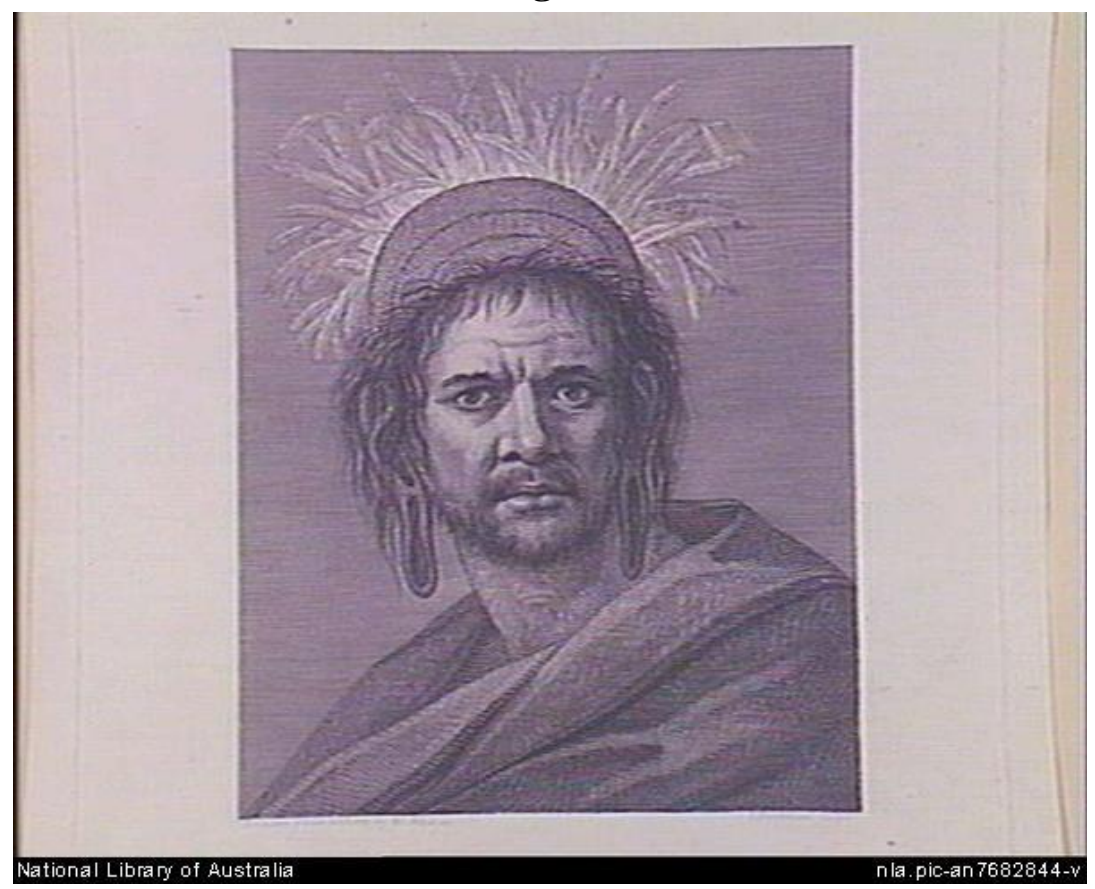

Fig 30 


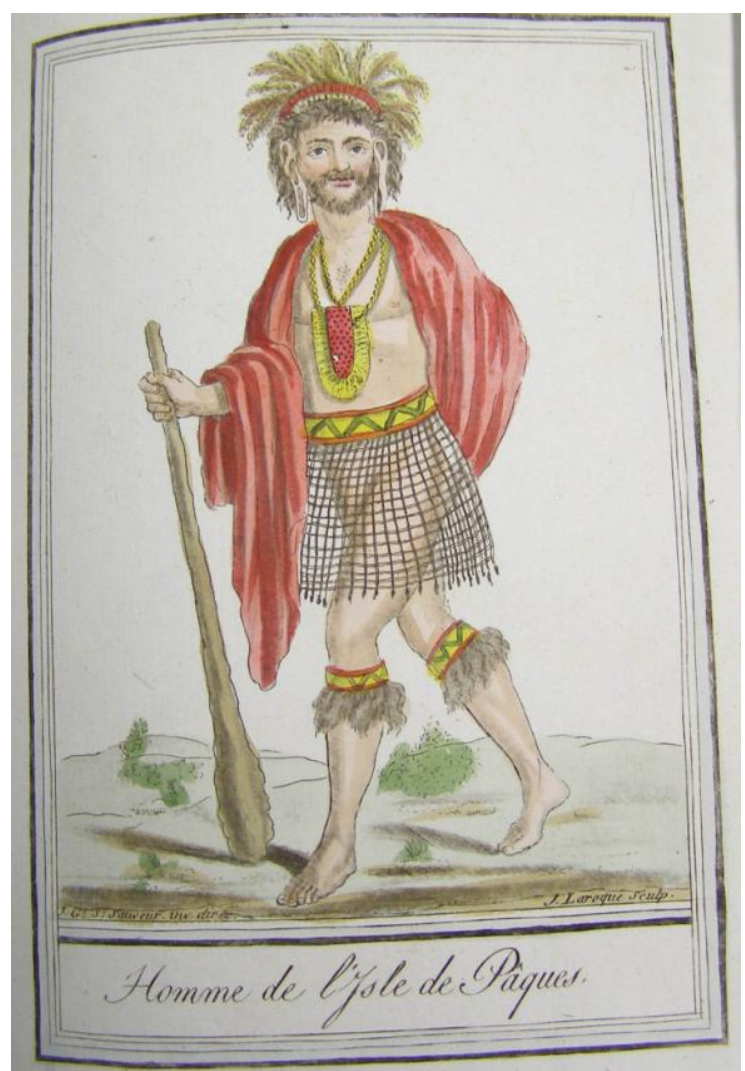

Fig 31

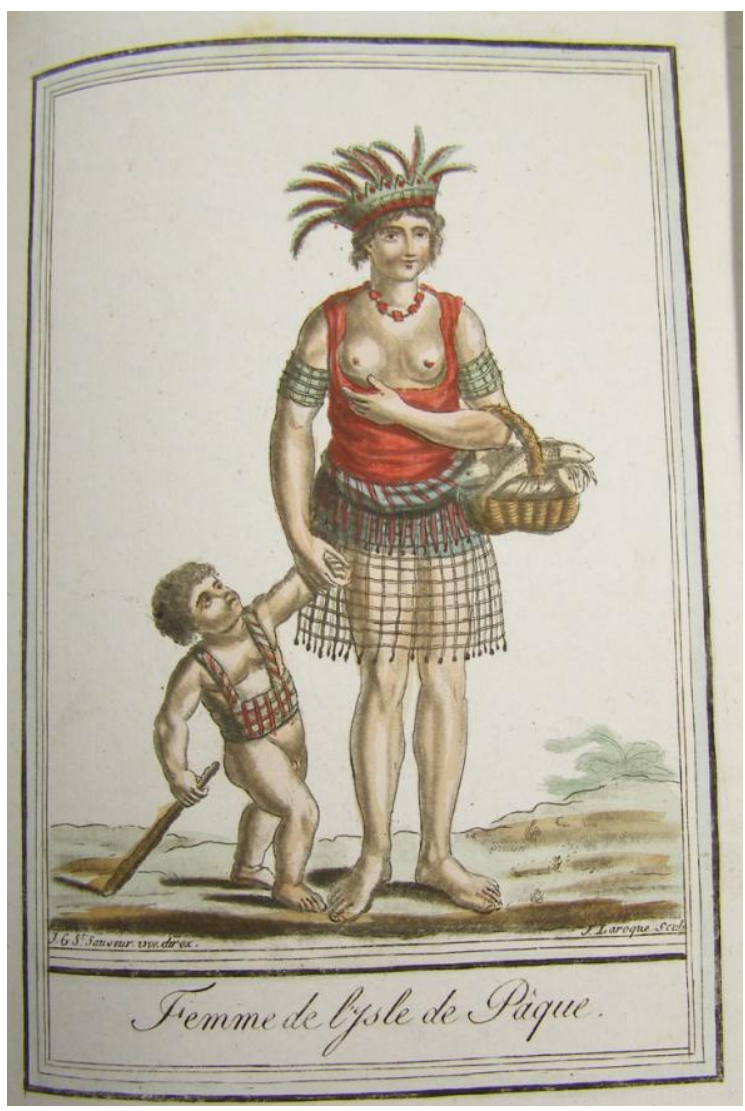

Fig 32 


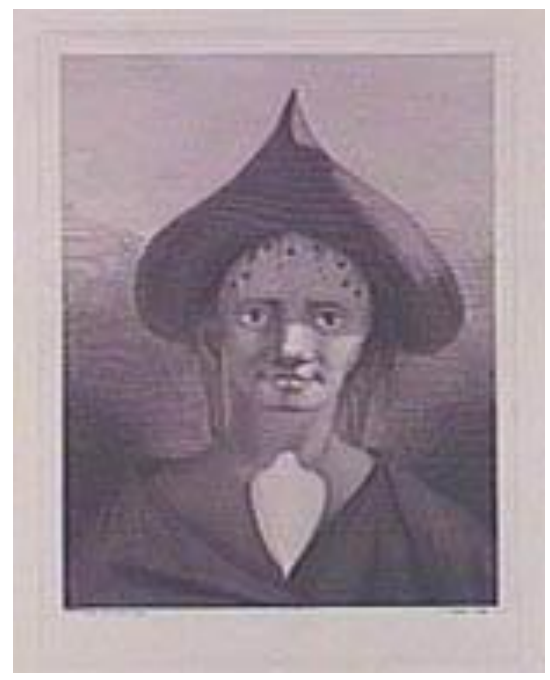

Fig 33

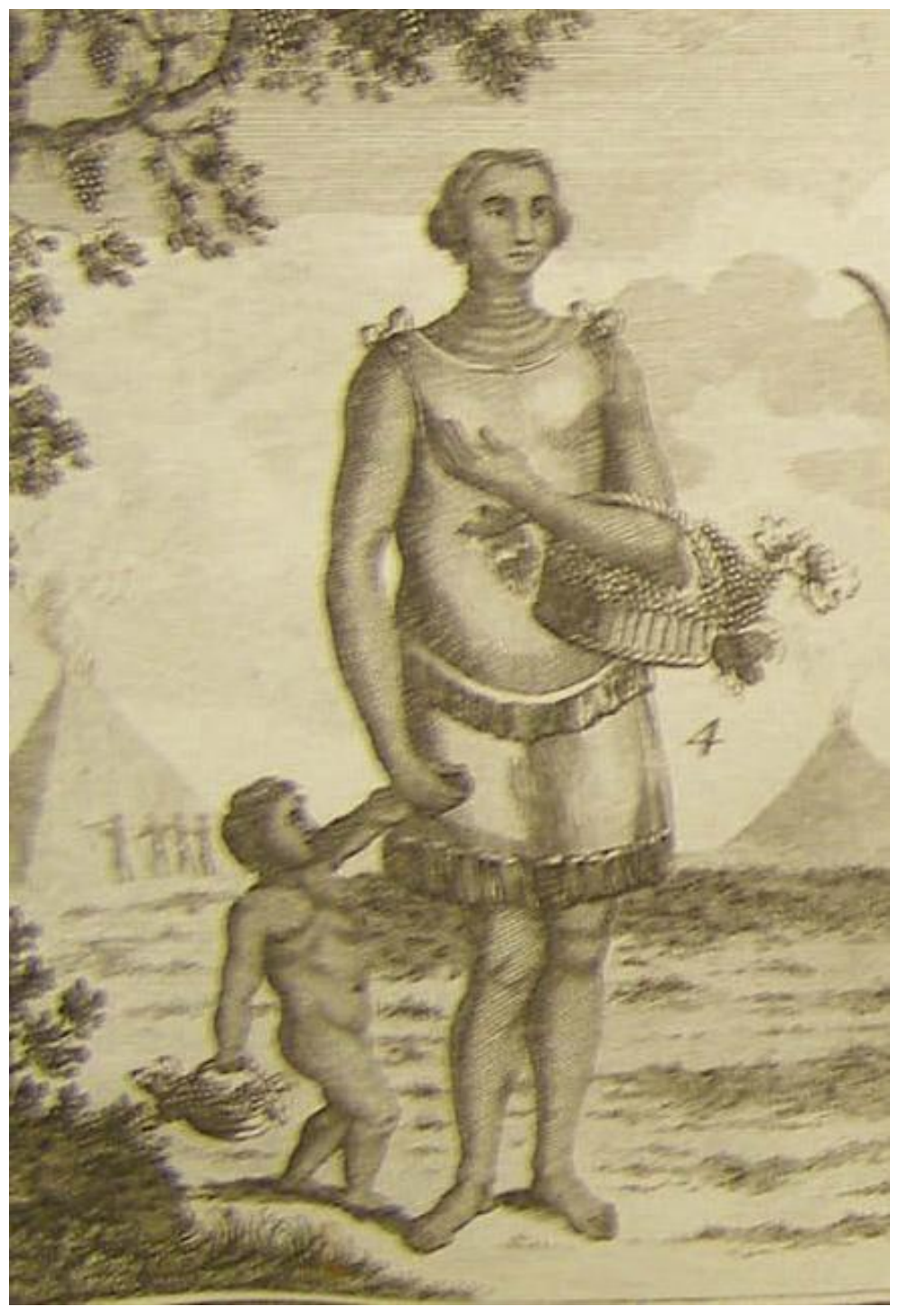

Fig 34 (detail of woman on left - see below for full image) 


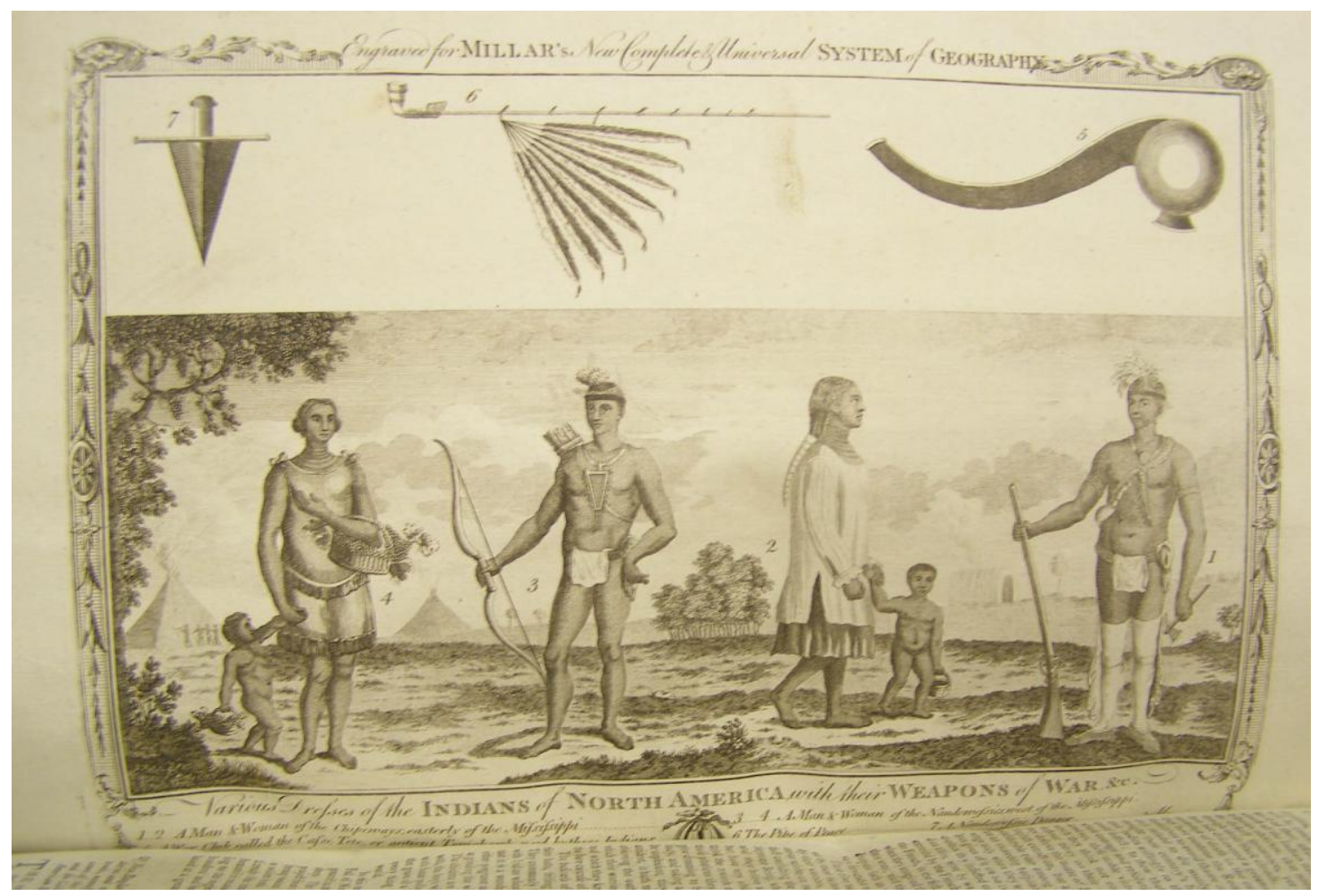

Fig 34

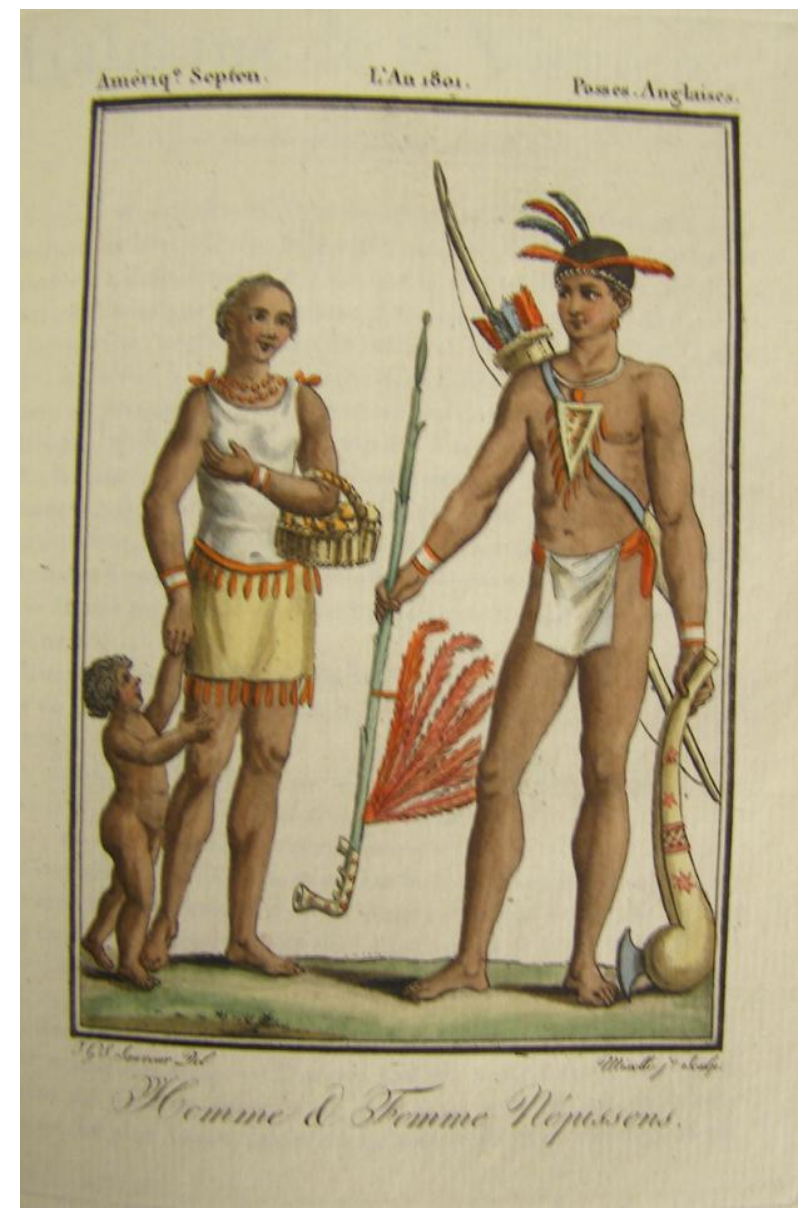

Fig 35 


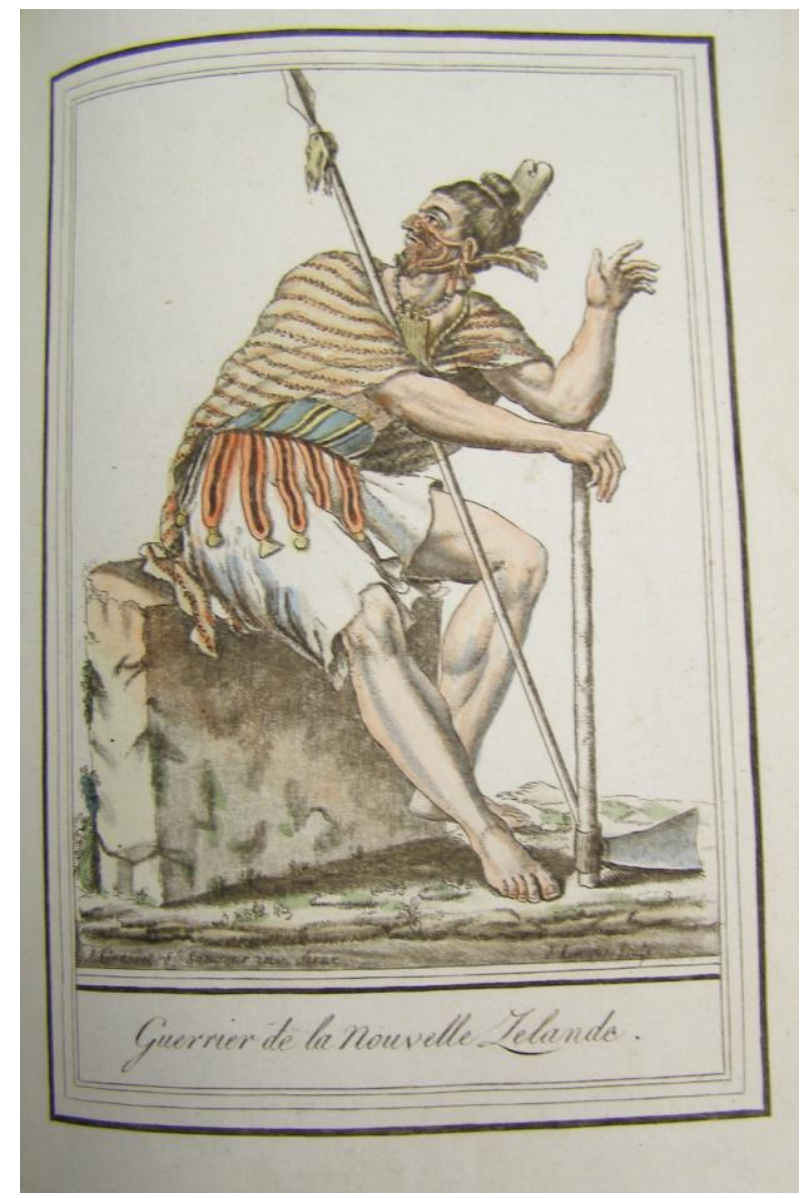

Fig 36

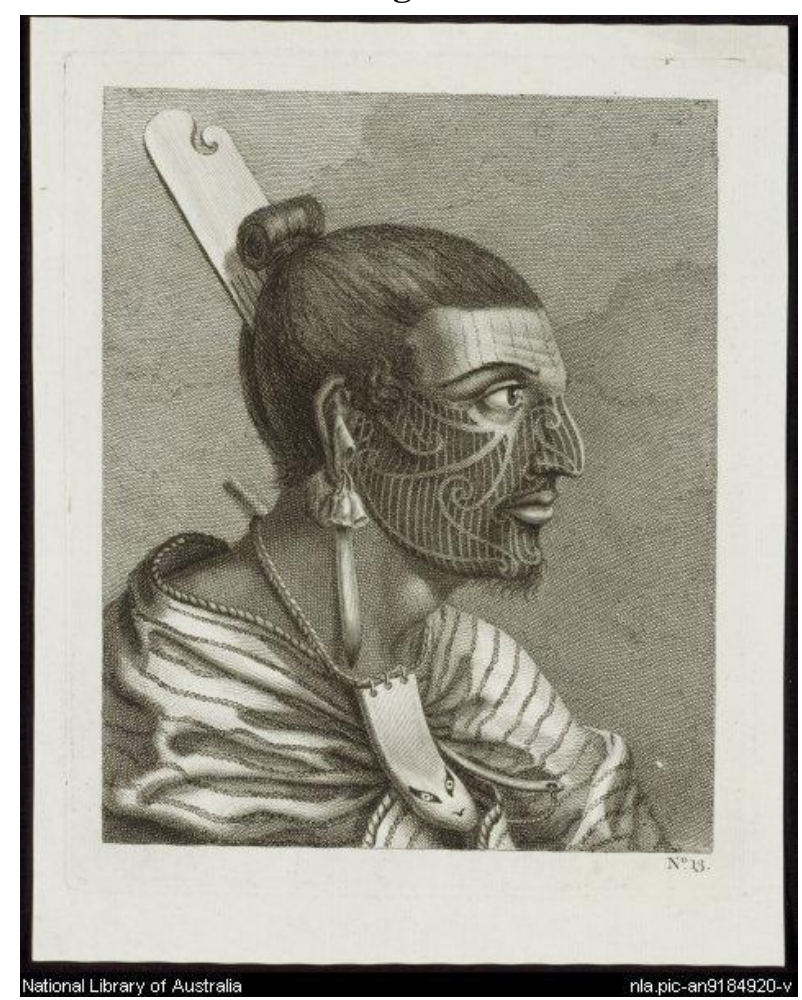

Fig 37 


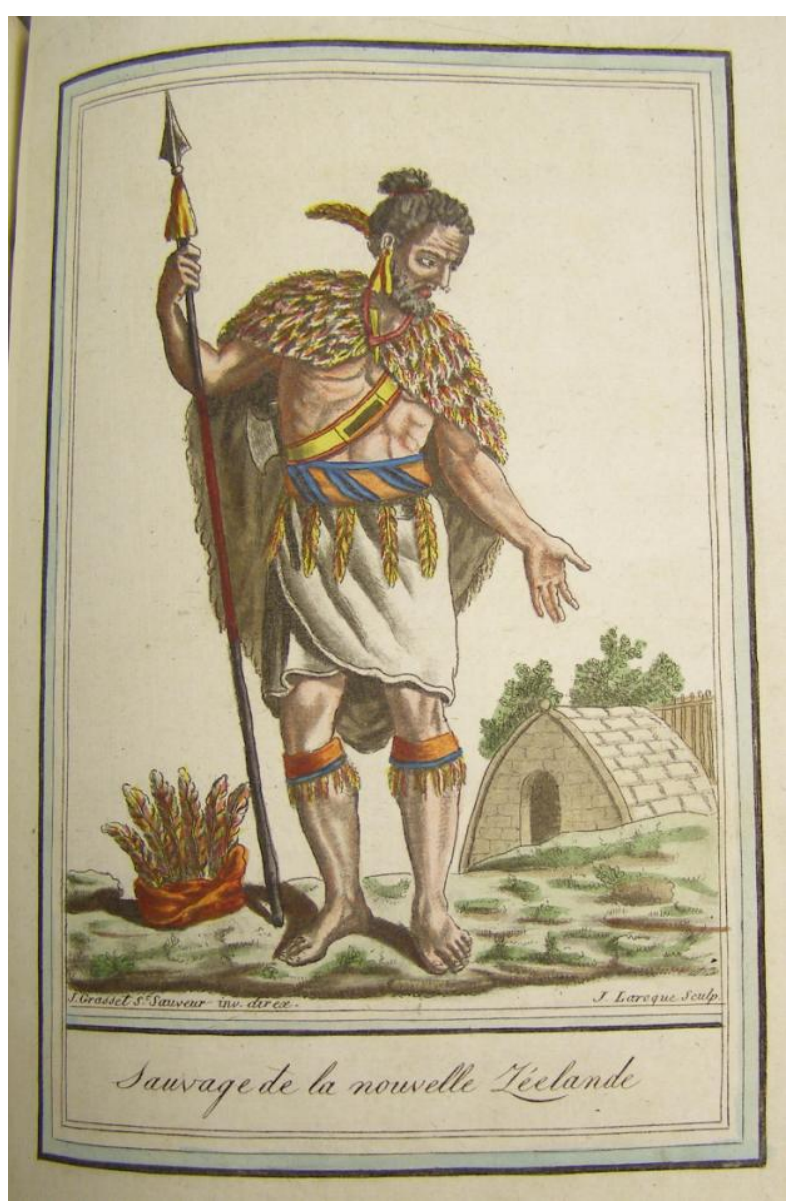

Fig 38

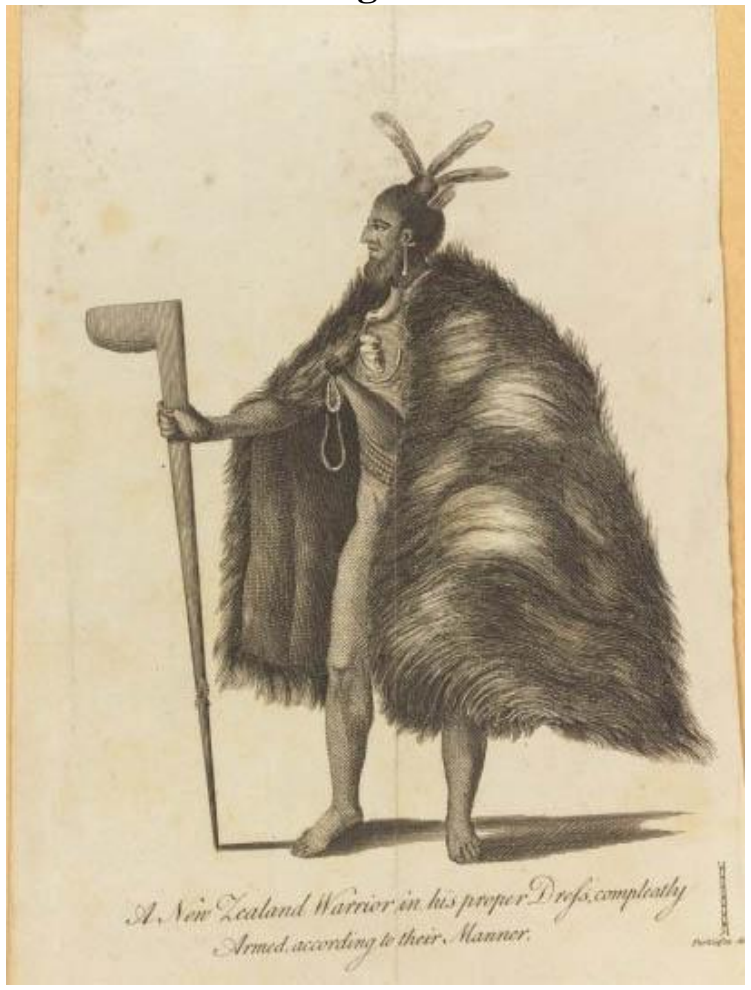

Fig 39 


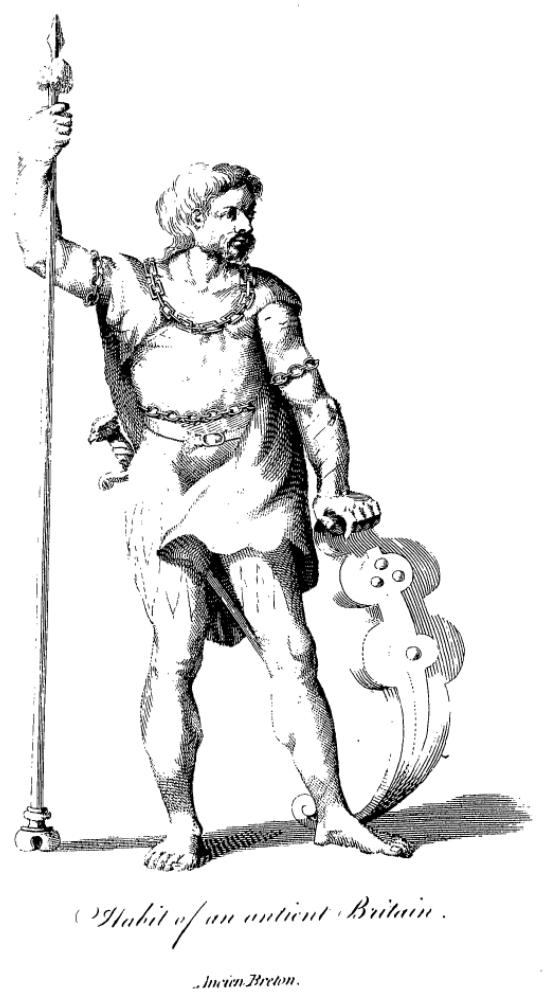

Fig 40

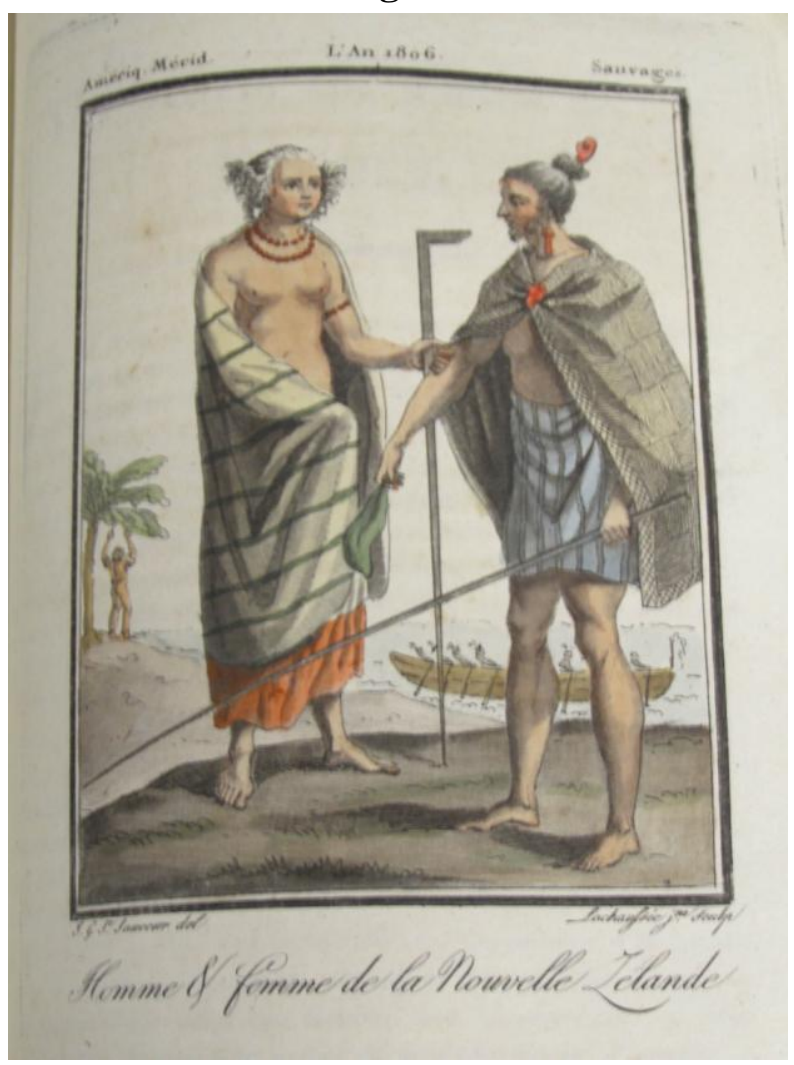

Fig 41 


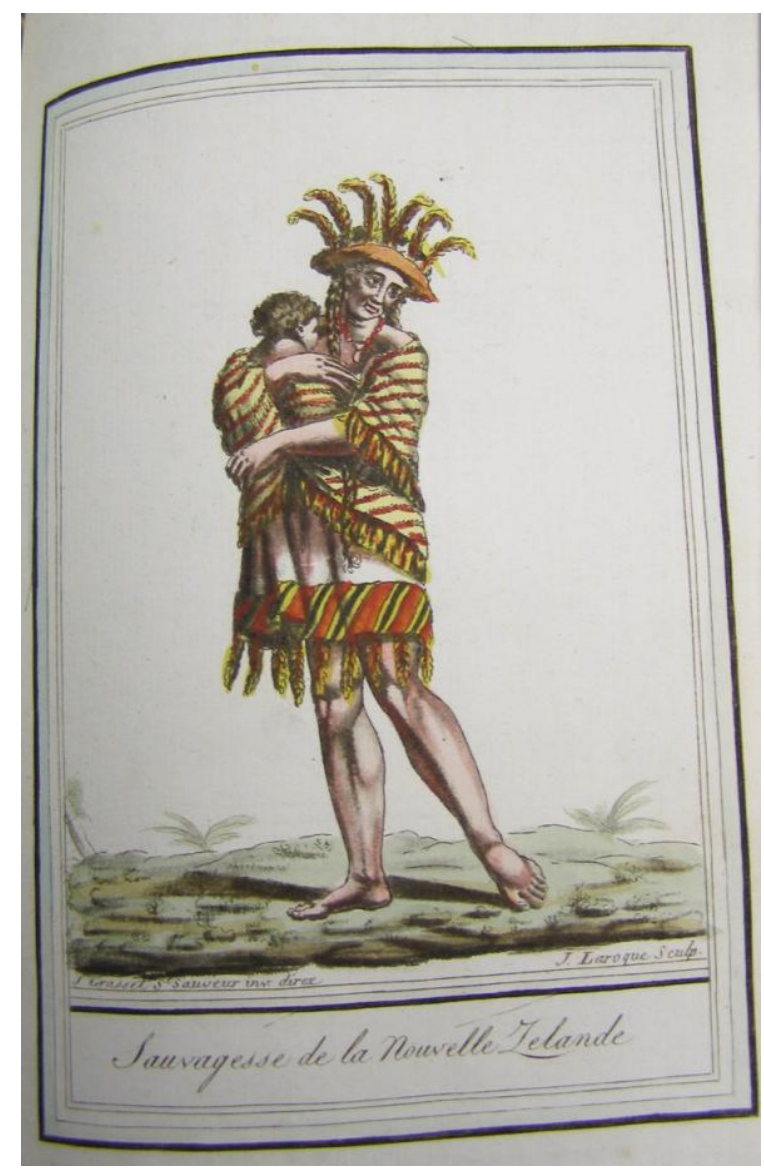

Fig 42

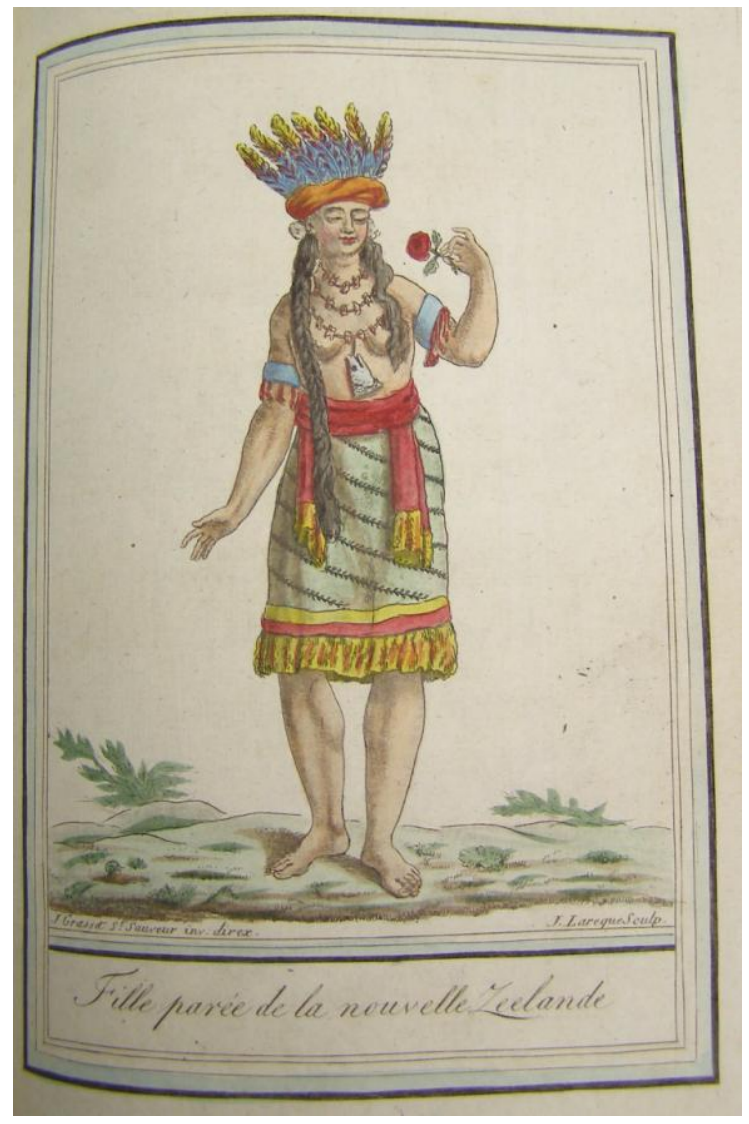

Fig 43 


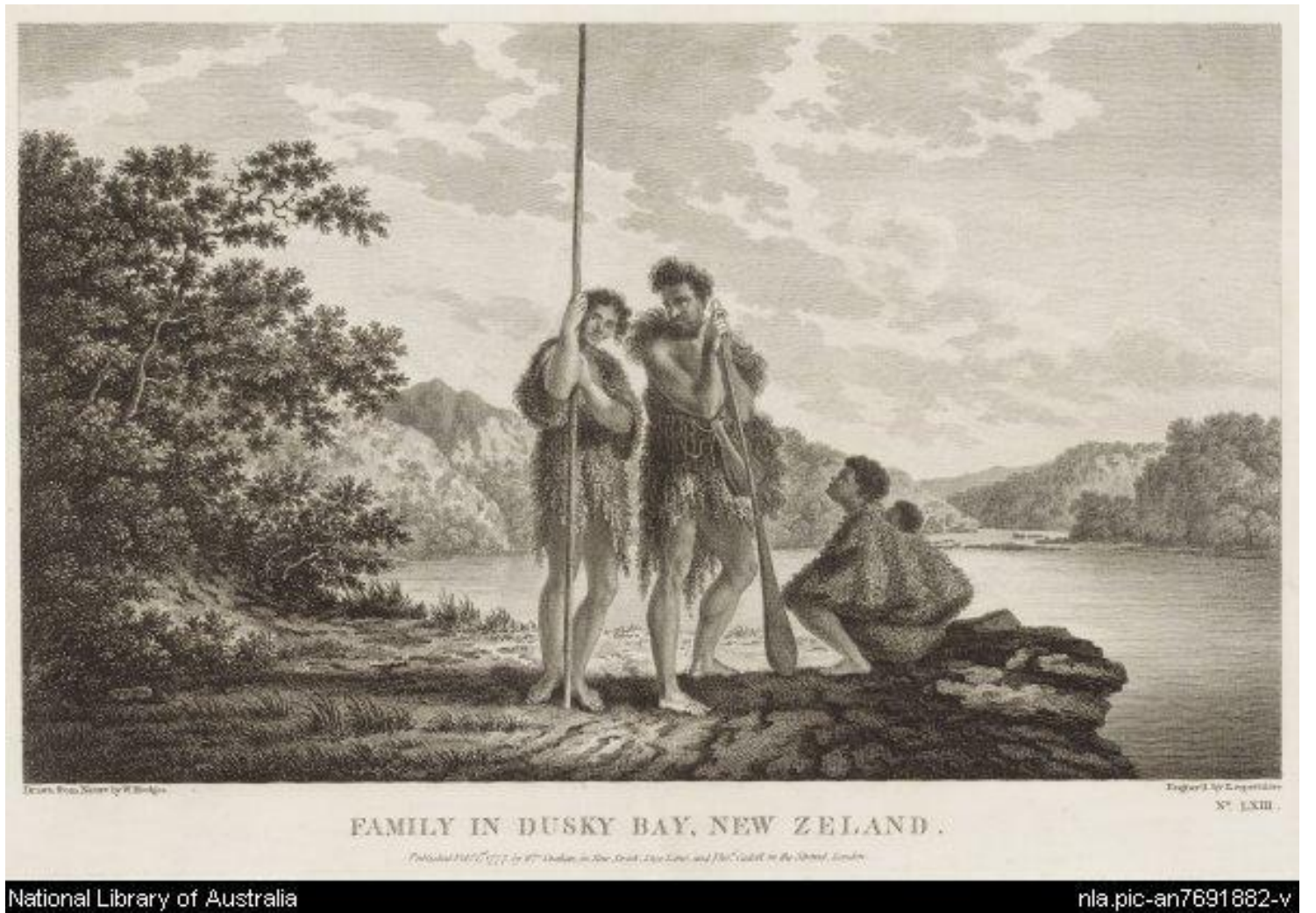

National Library of Australia

Fig 44

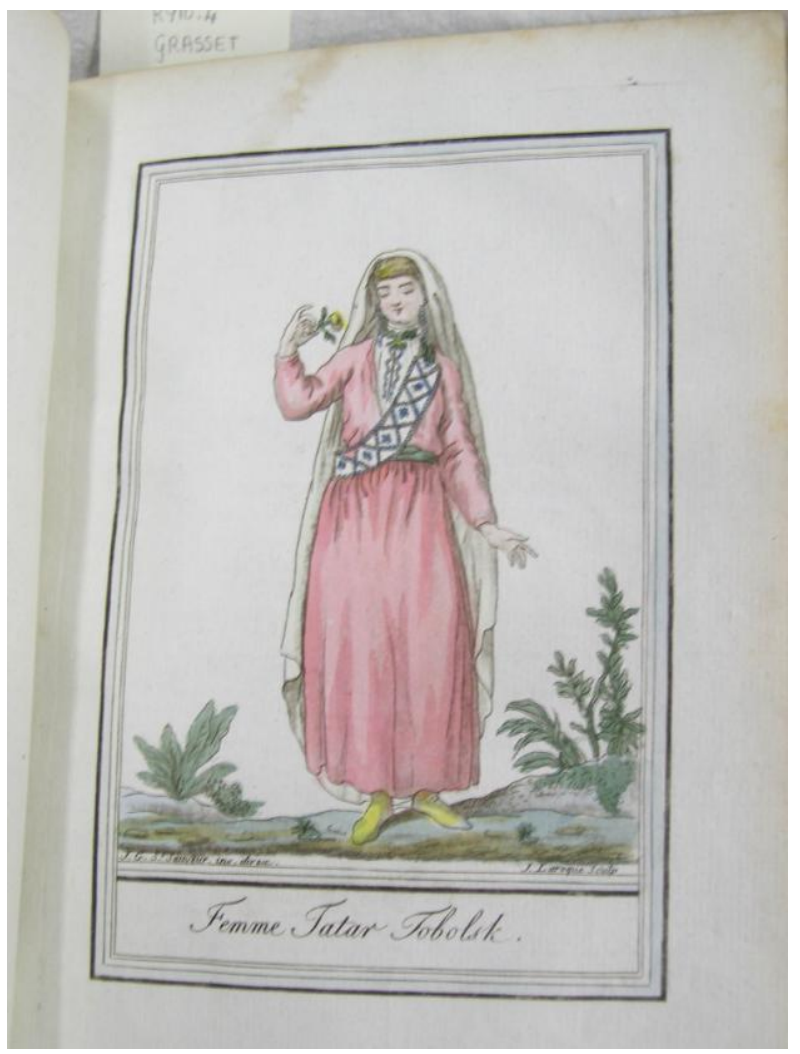

Fig 45 


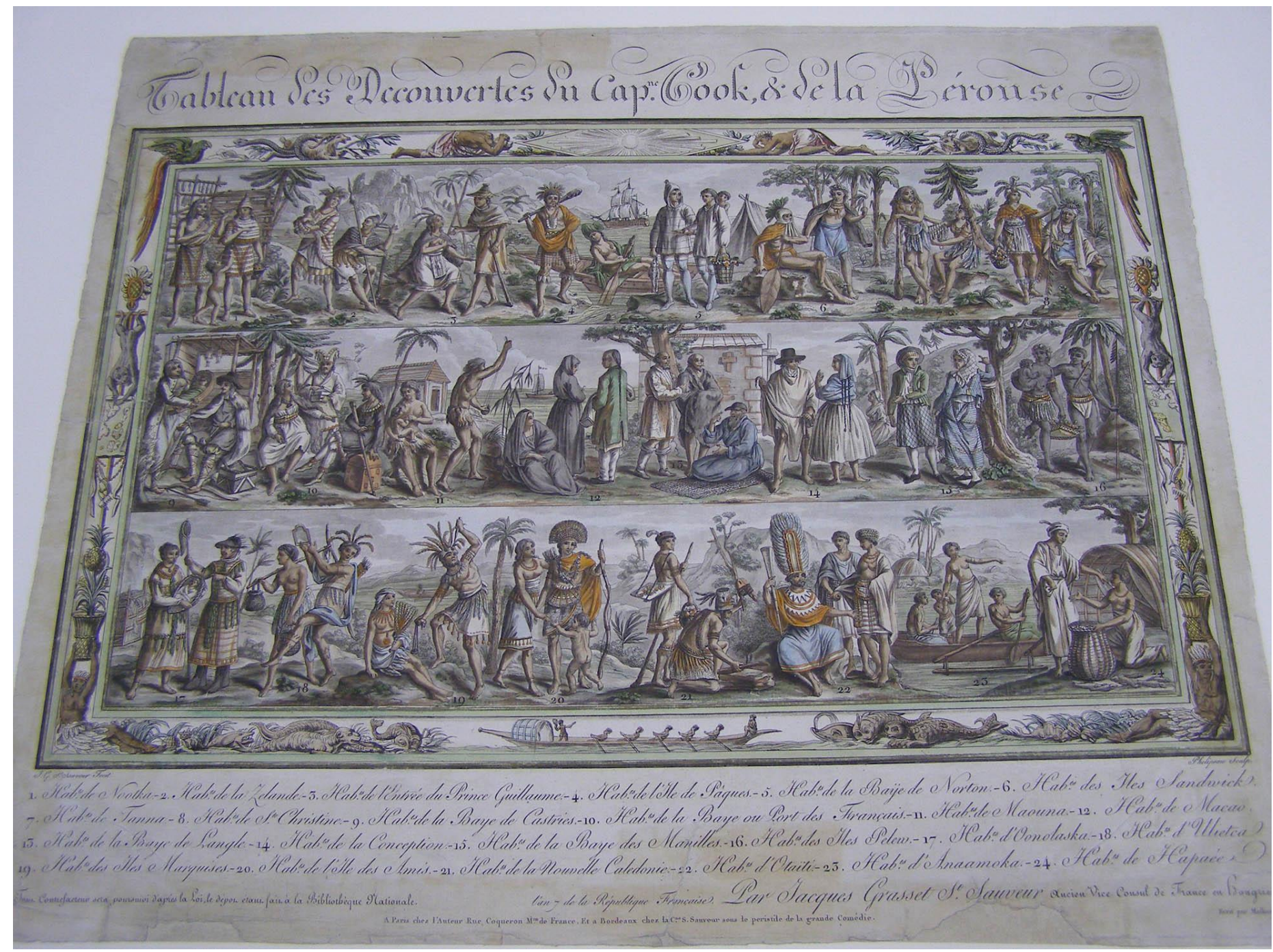

Fig 46 


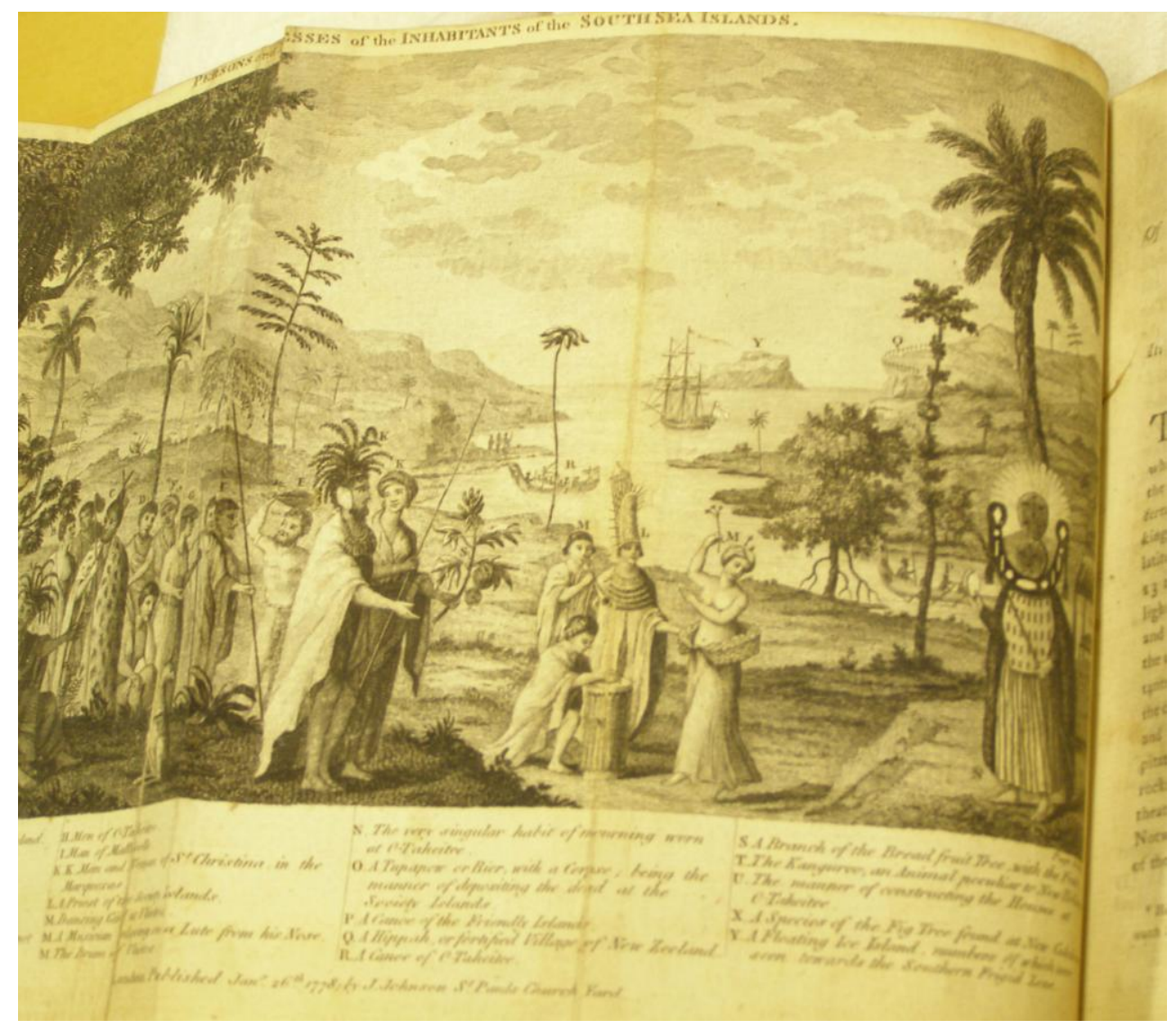

Fig 47

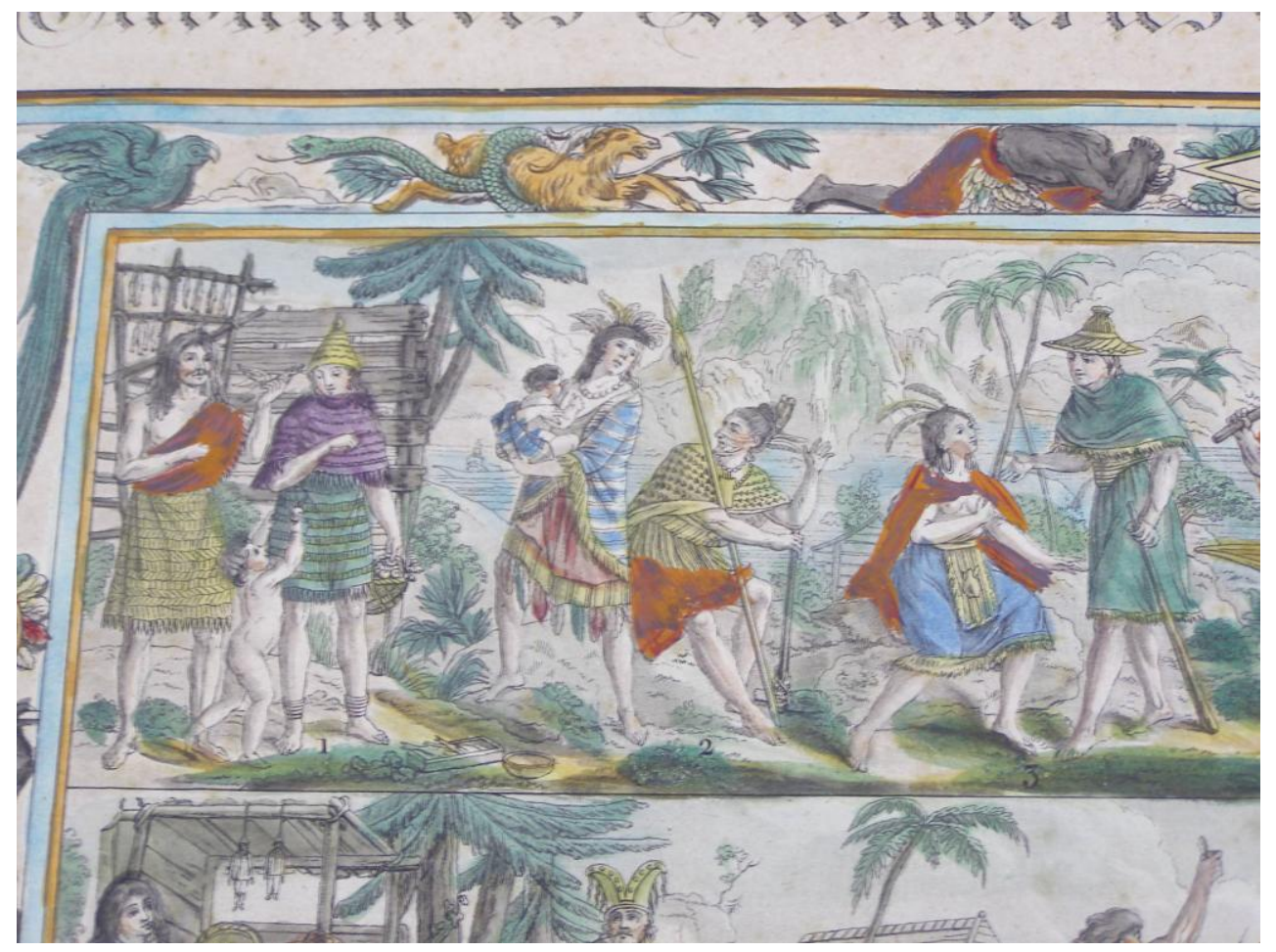

Fig 48 


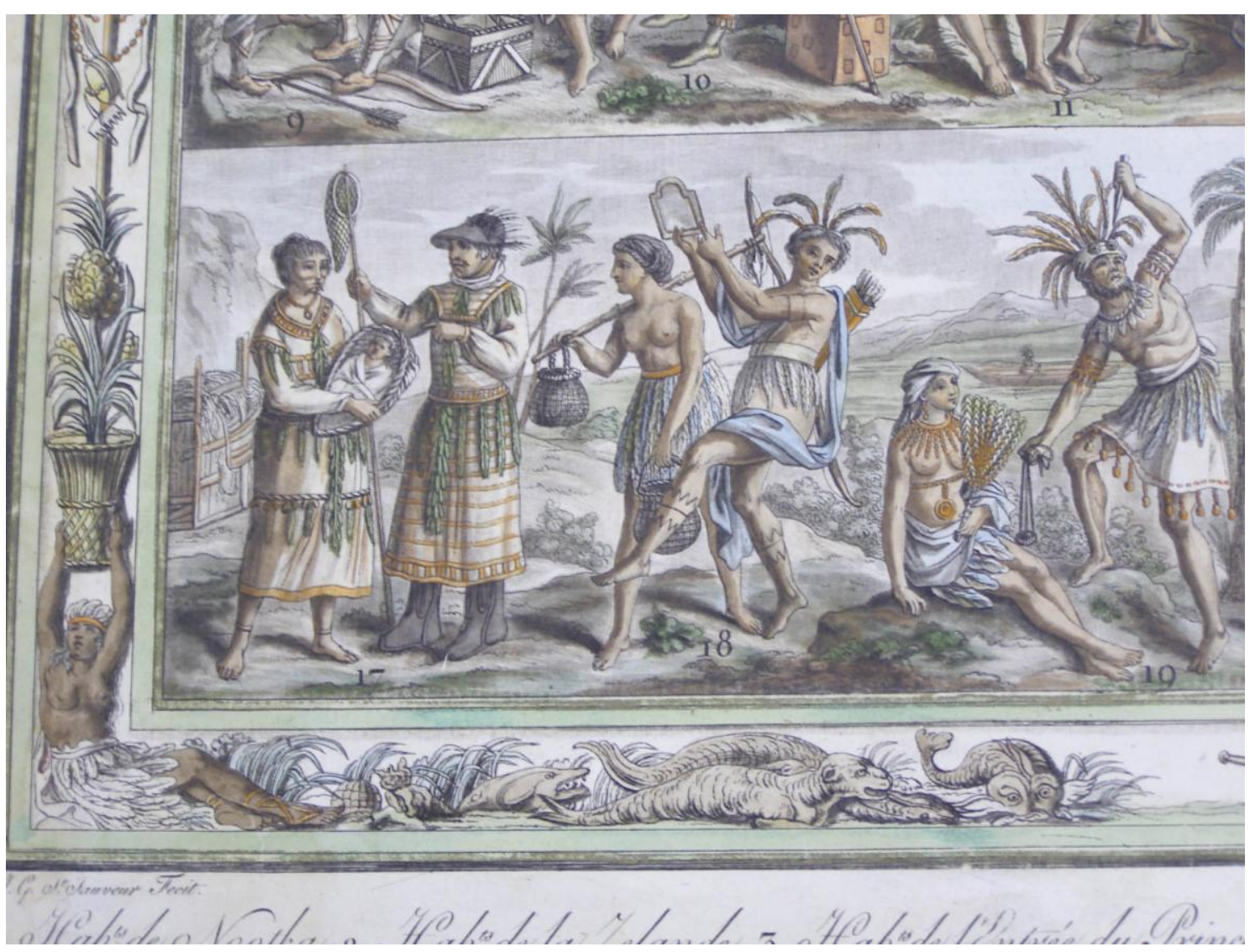

Fig 49 


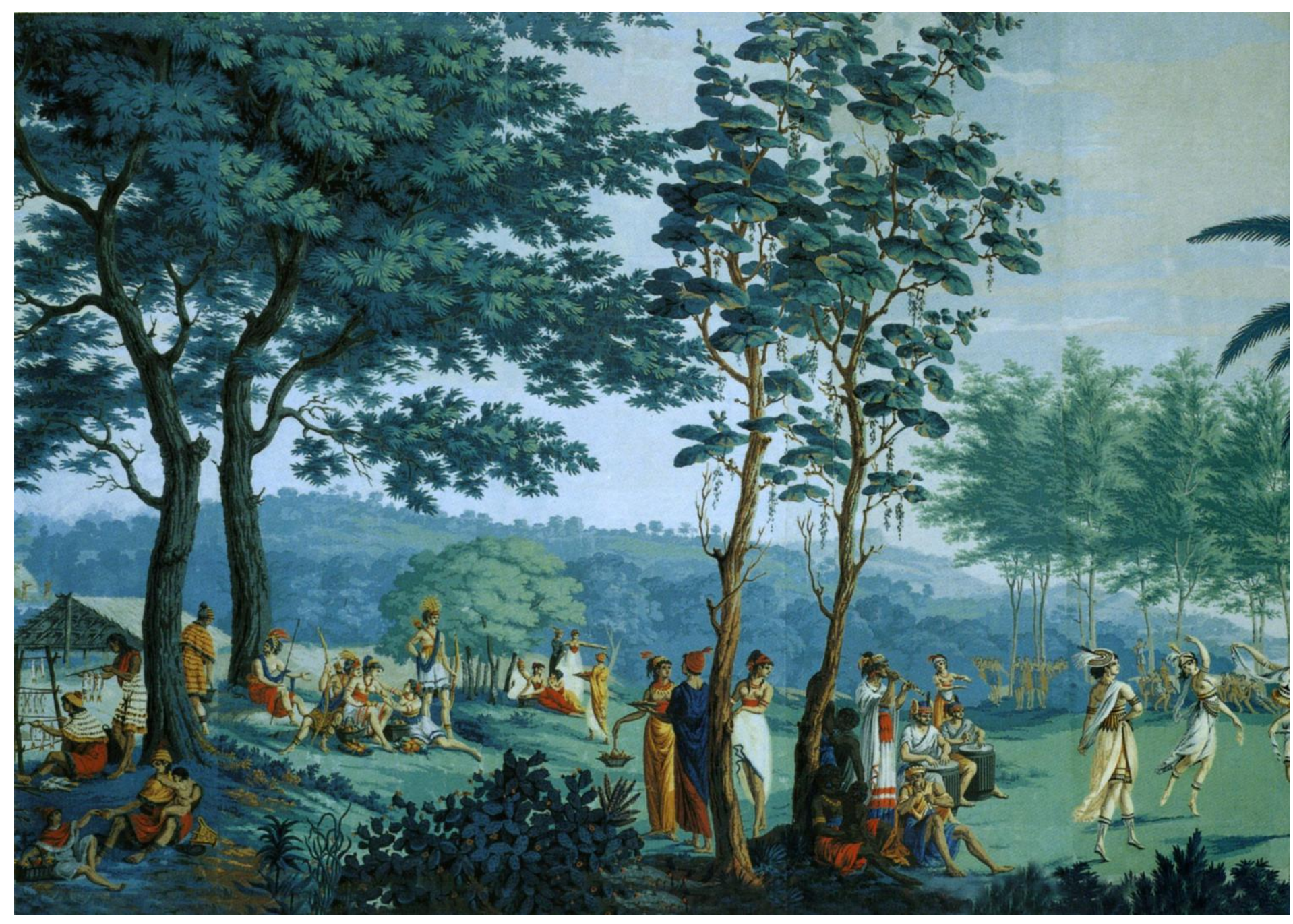

Fig 50 


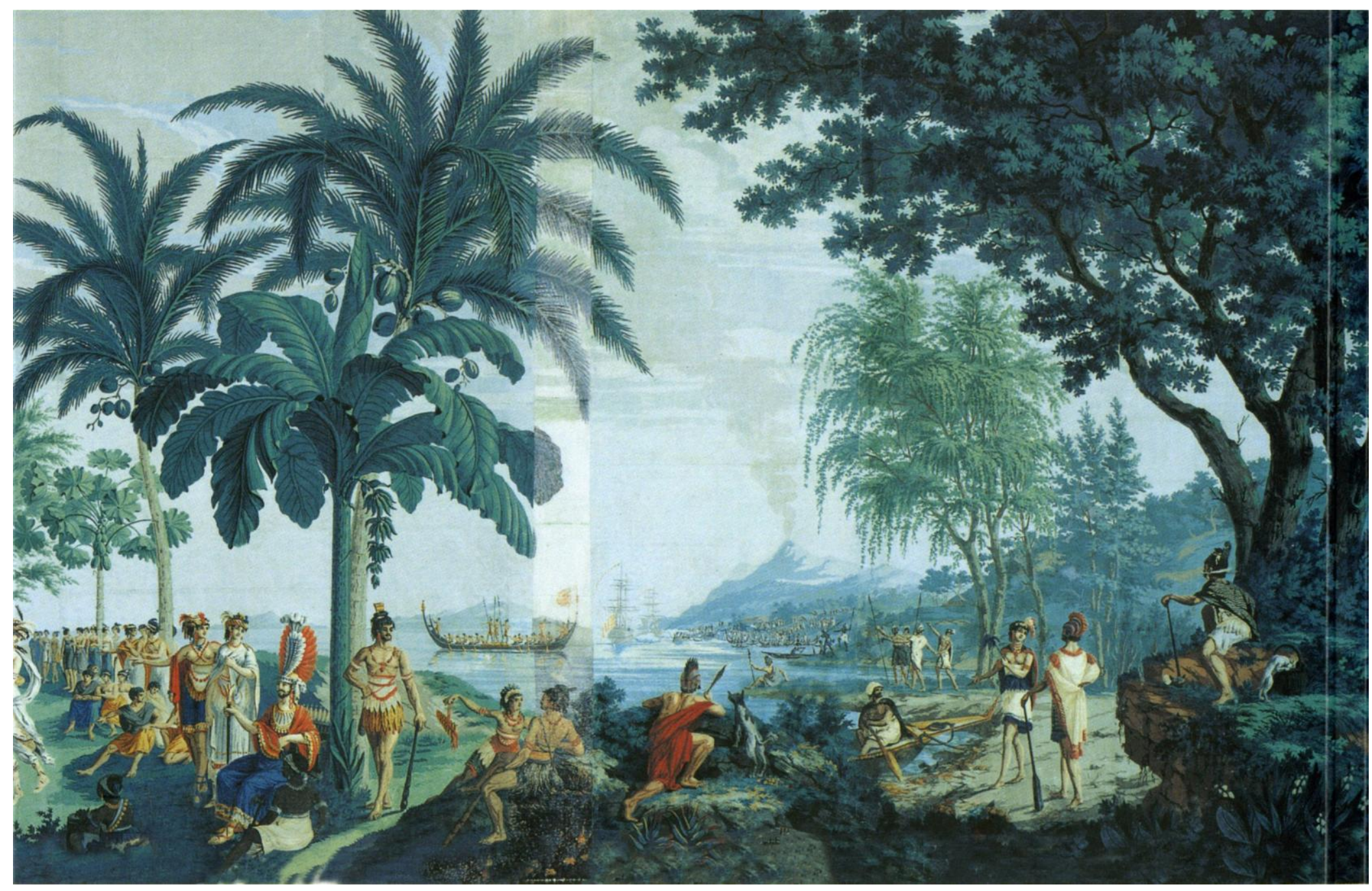

Fig 51 


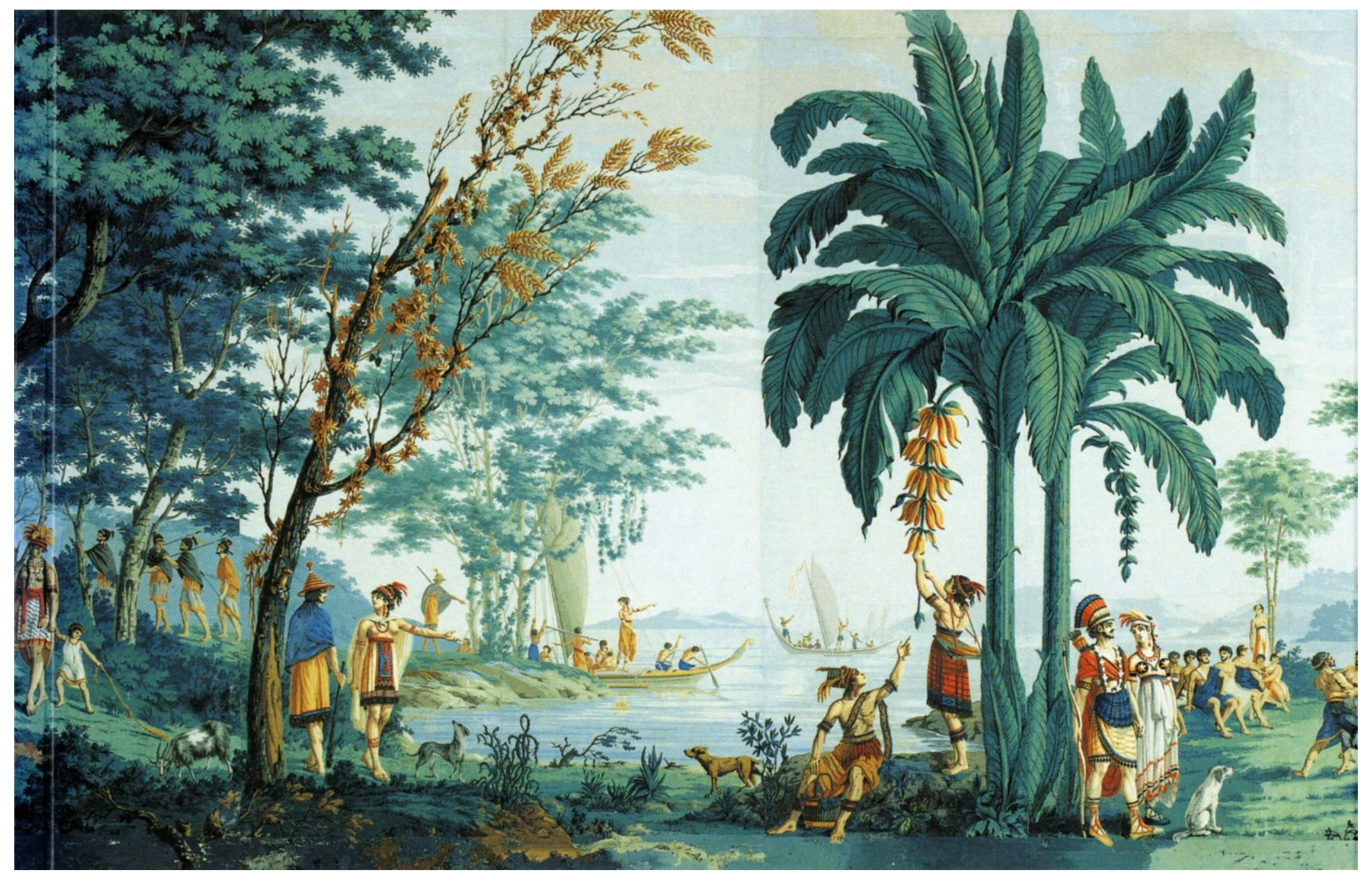

Fig 52 


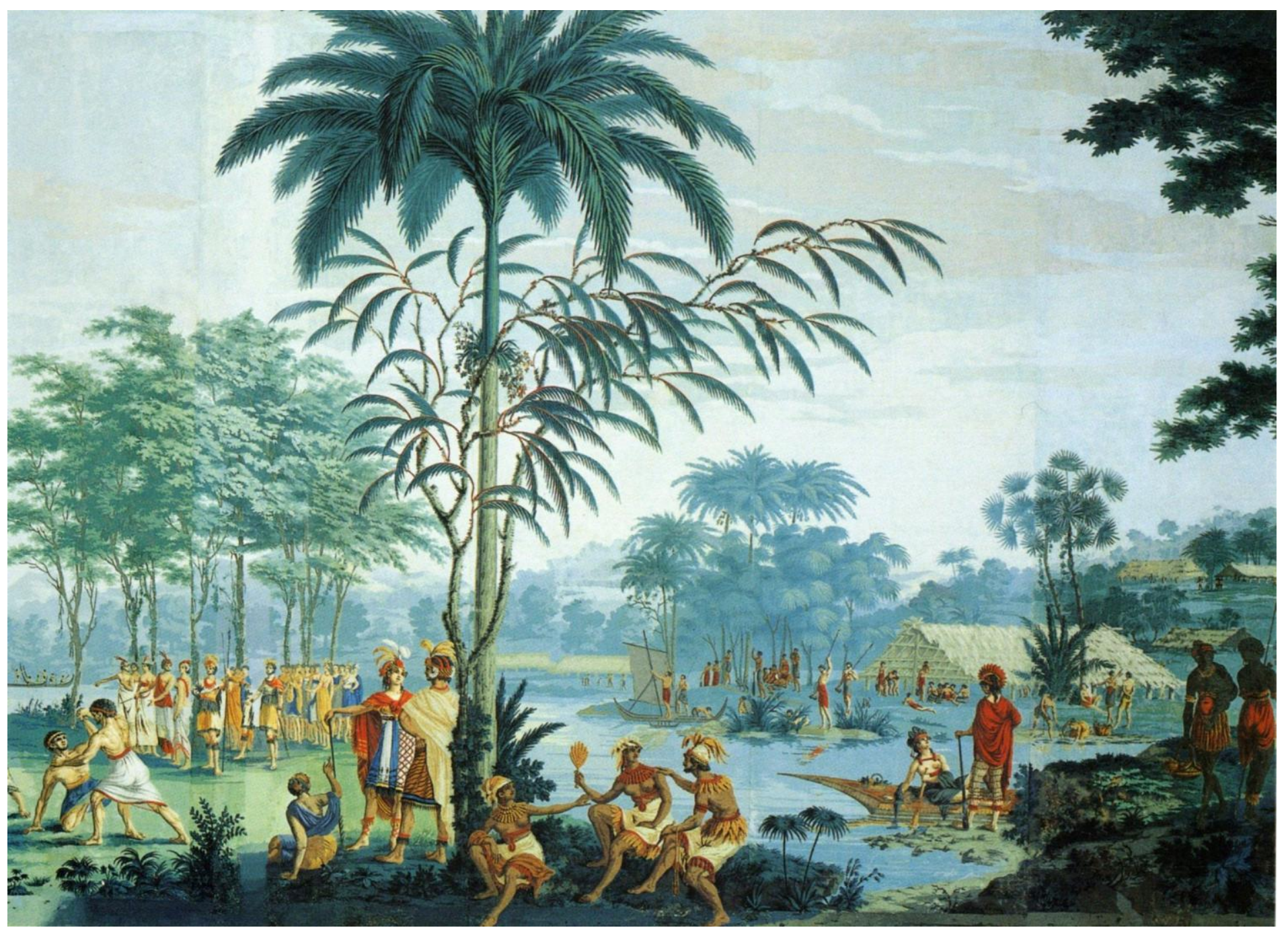

Fig 53 

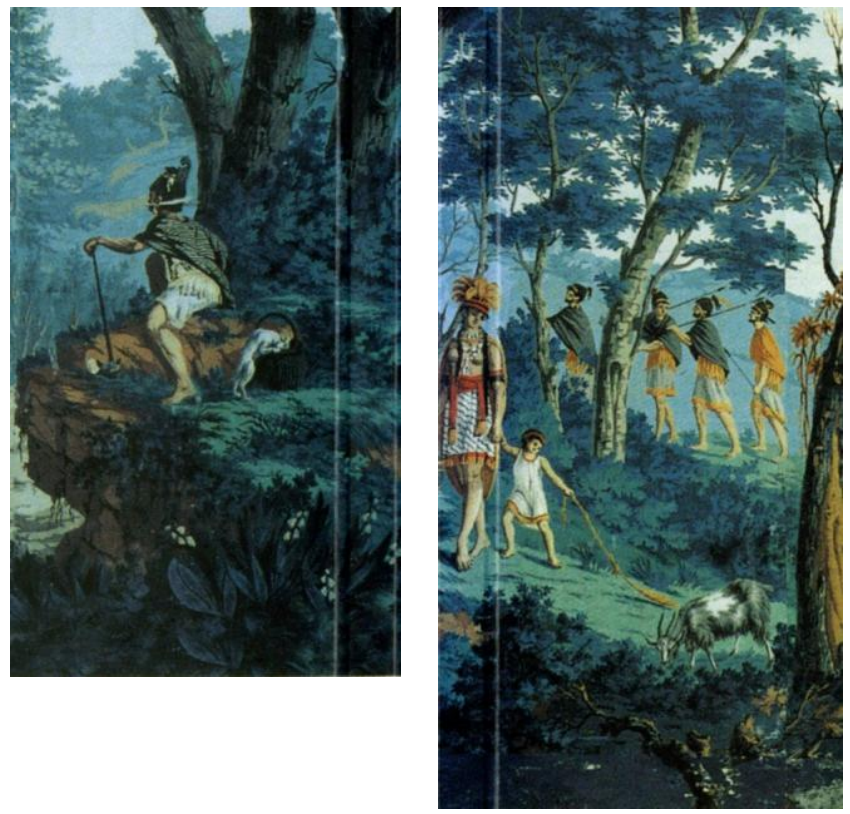

Fig 54

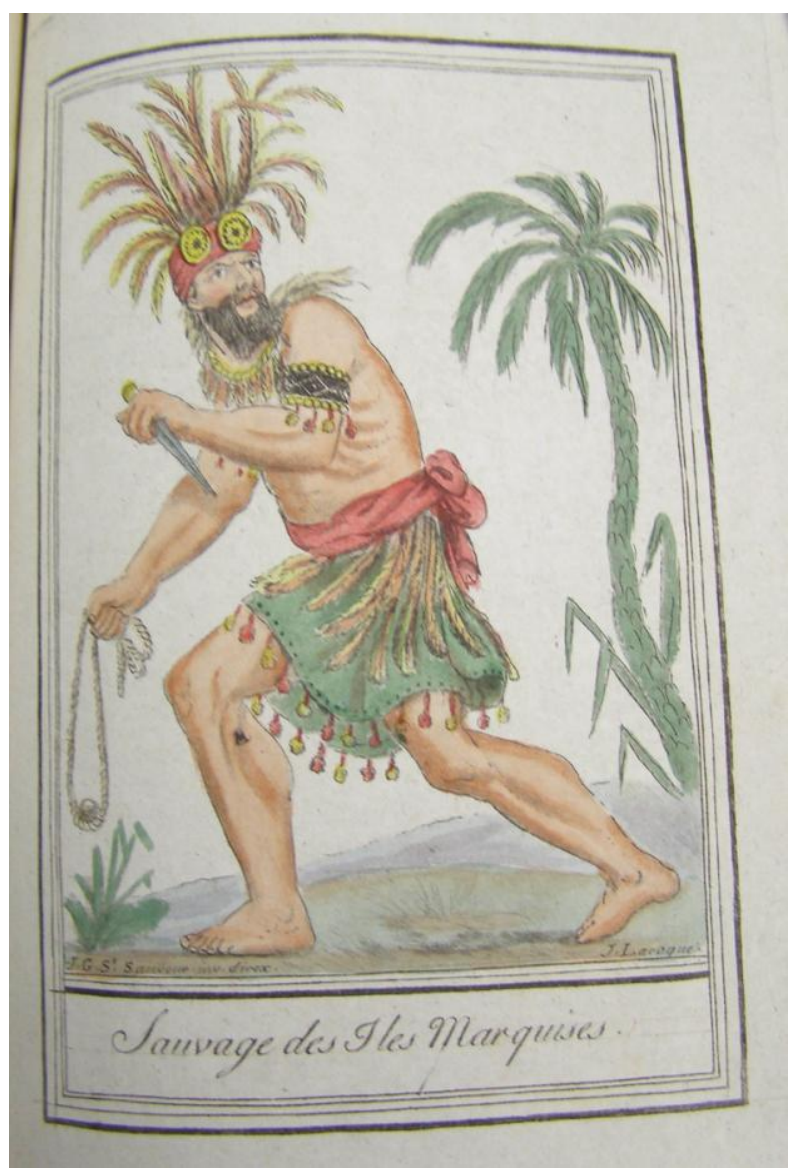

Fig 55 


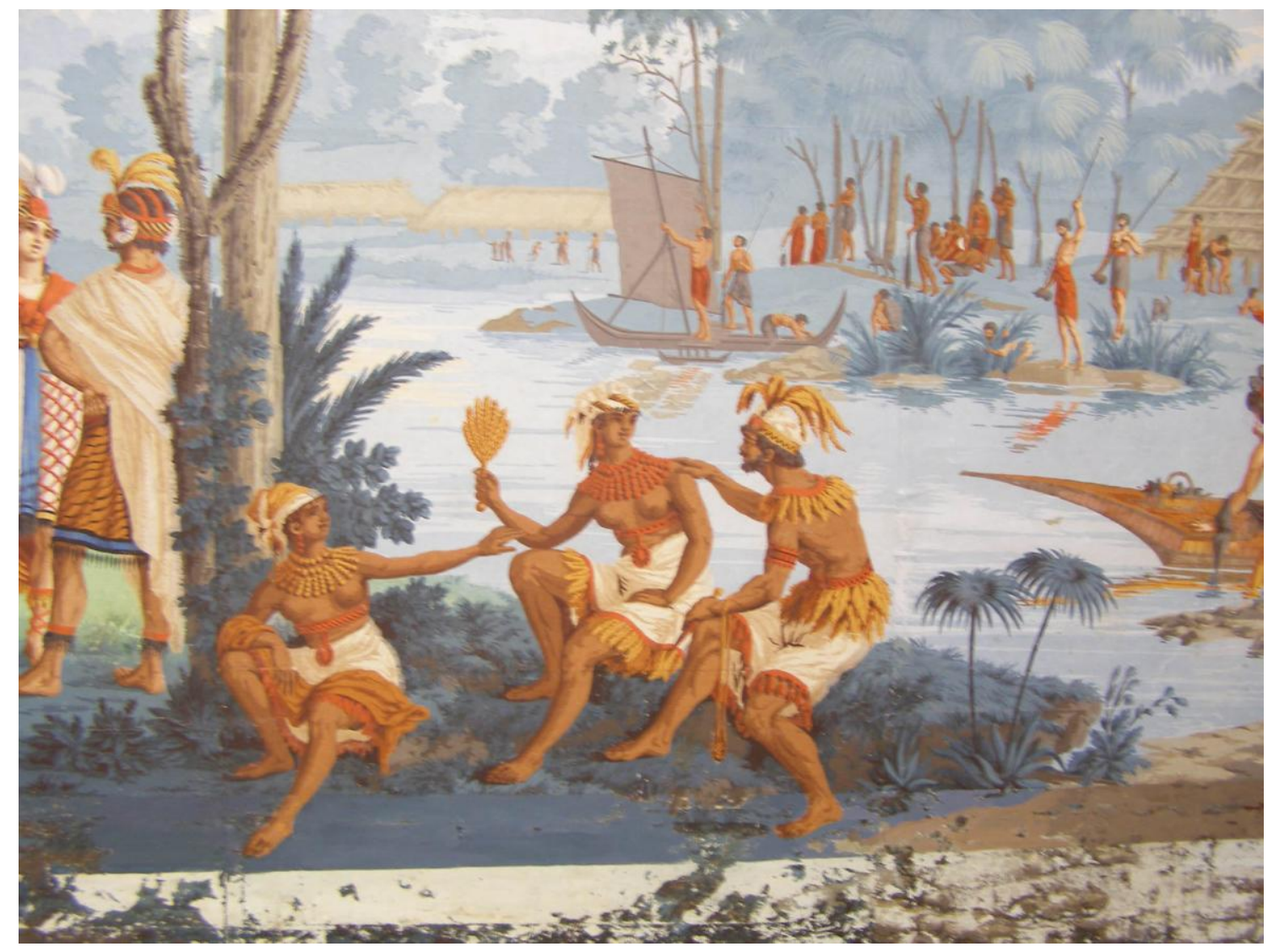

Fig 56
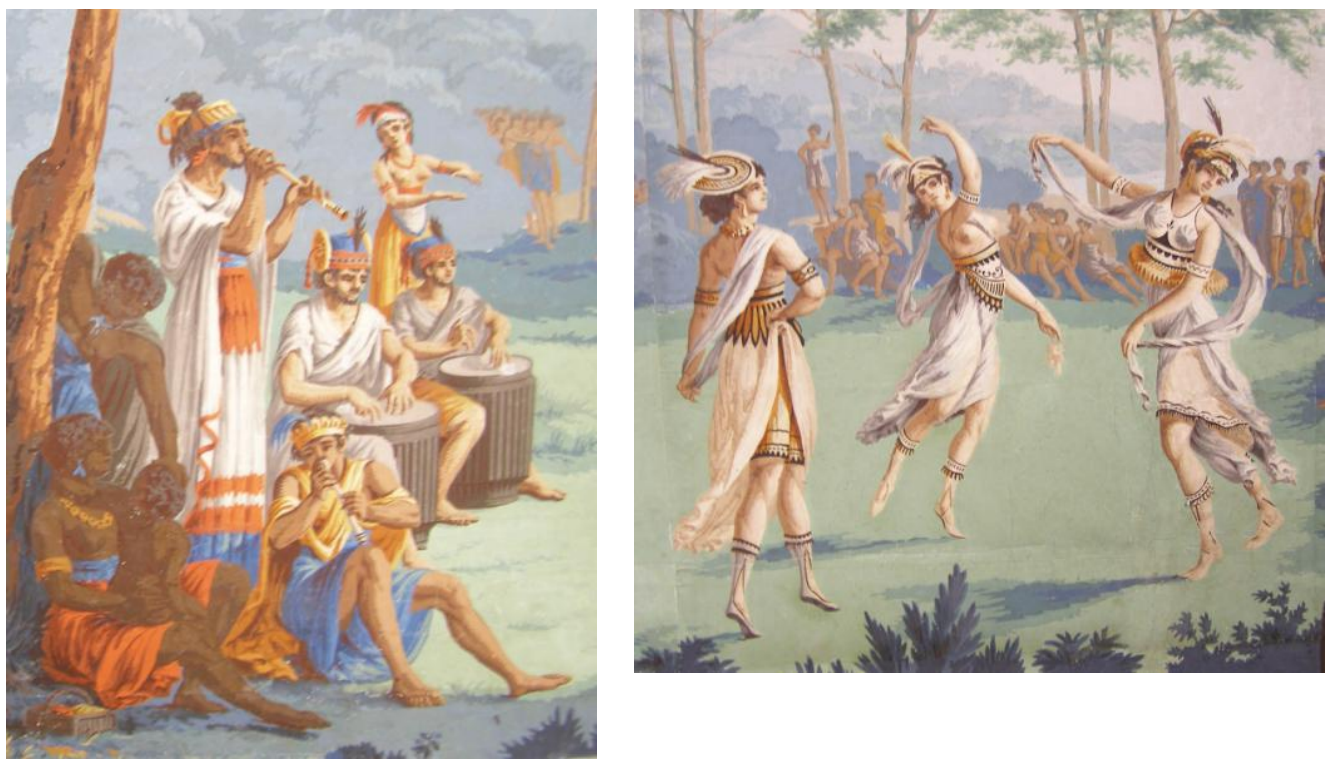

Fig 57 


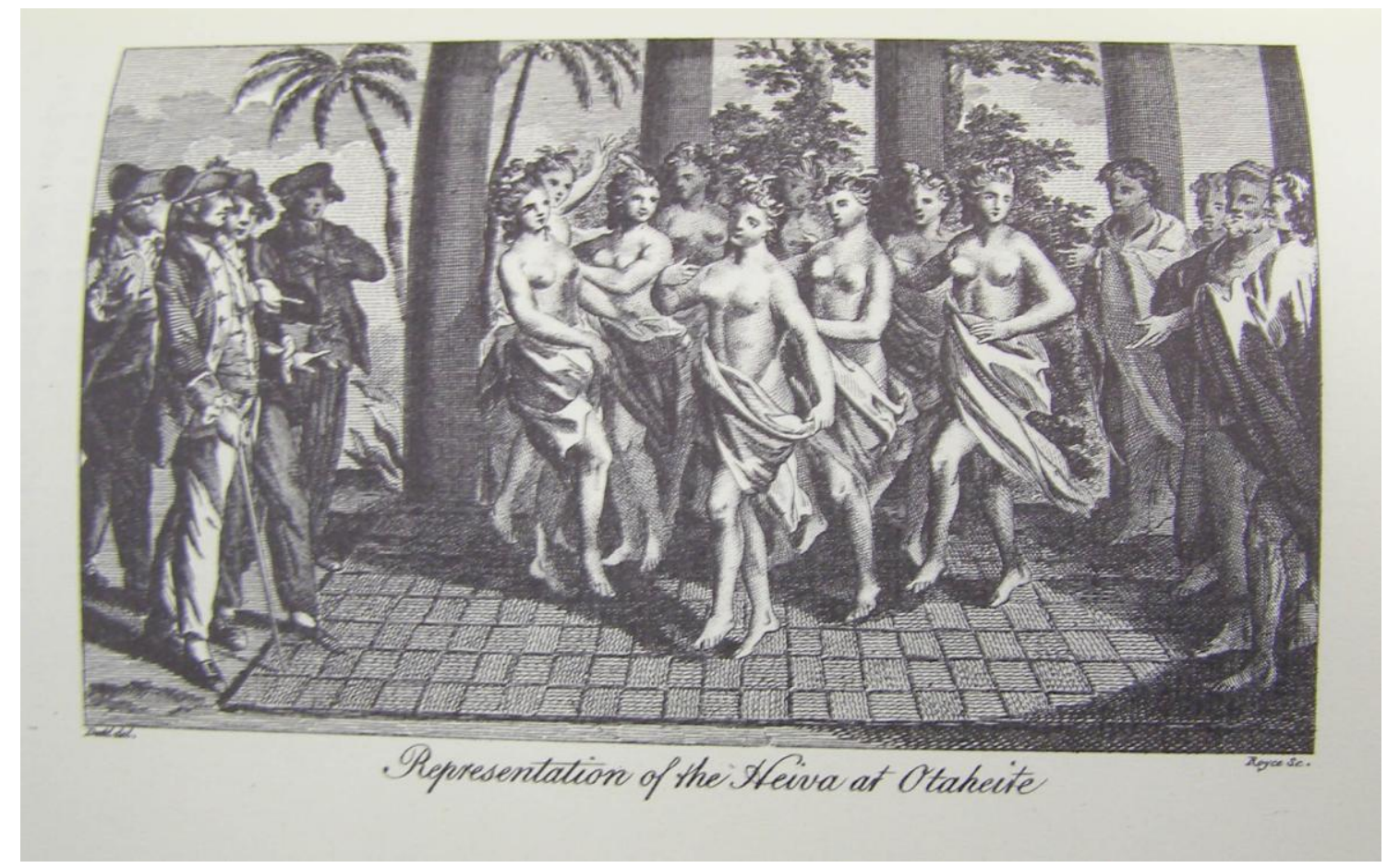

Fig 58

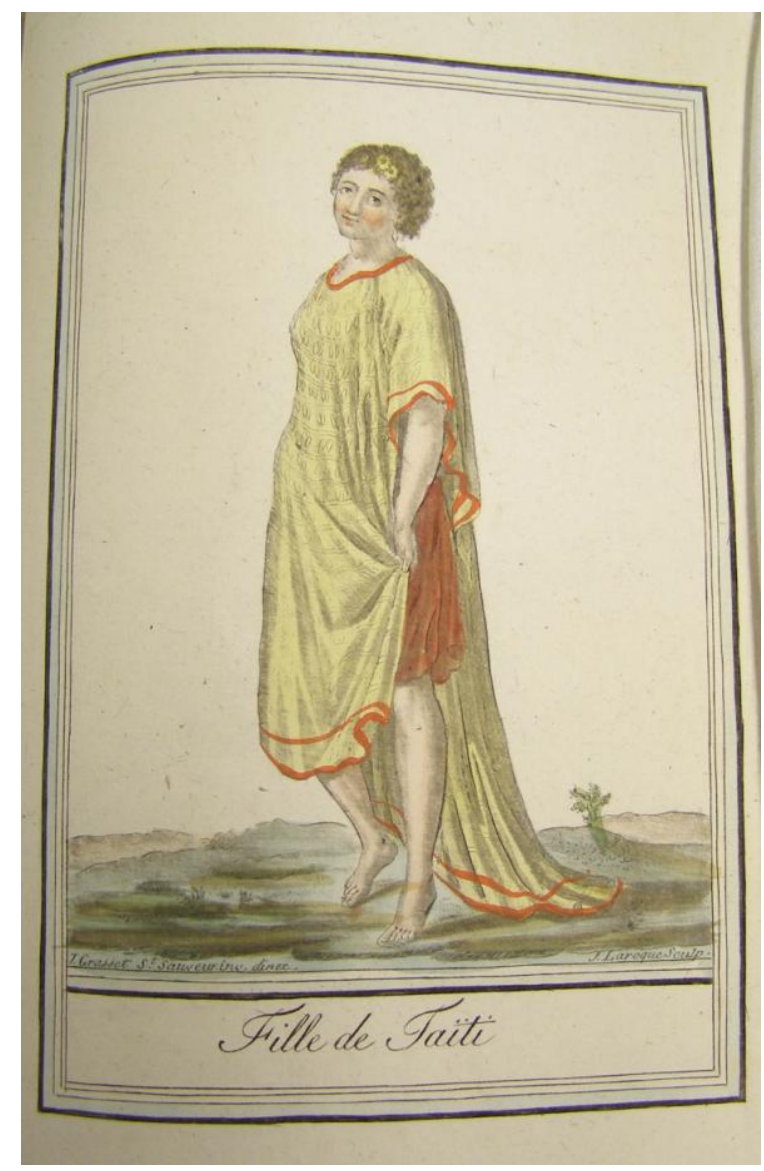

Fig 59 


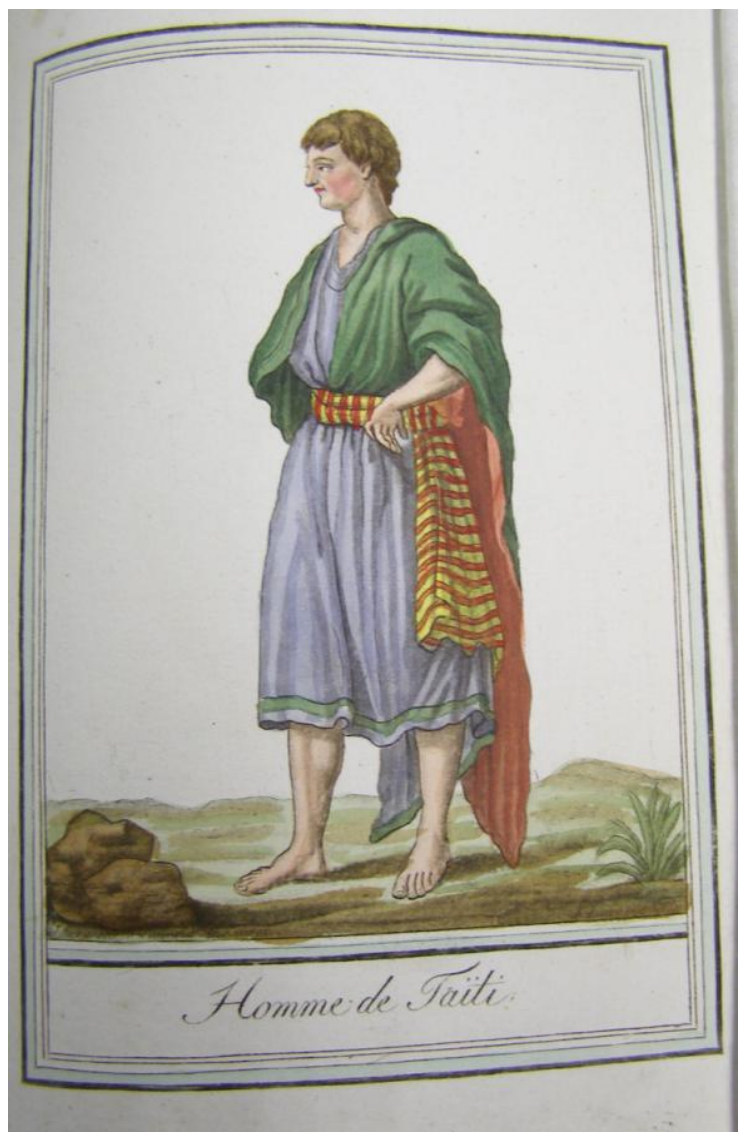

Fig 60

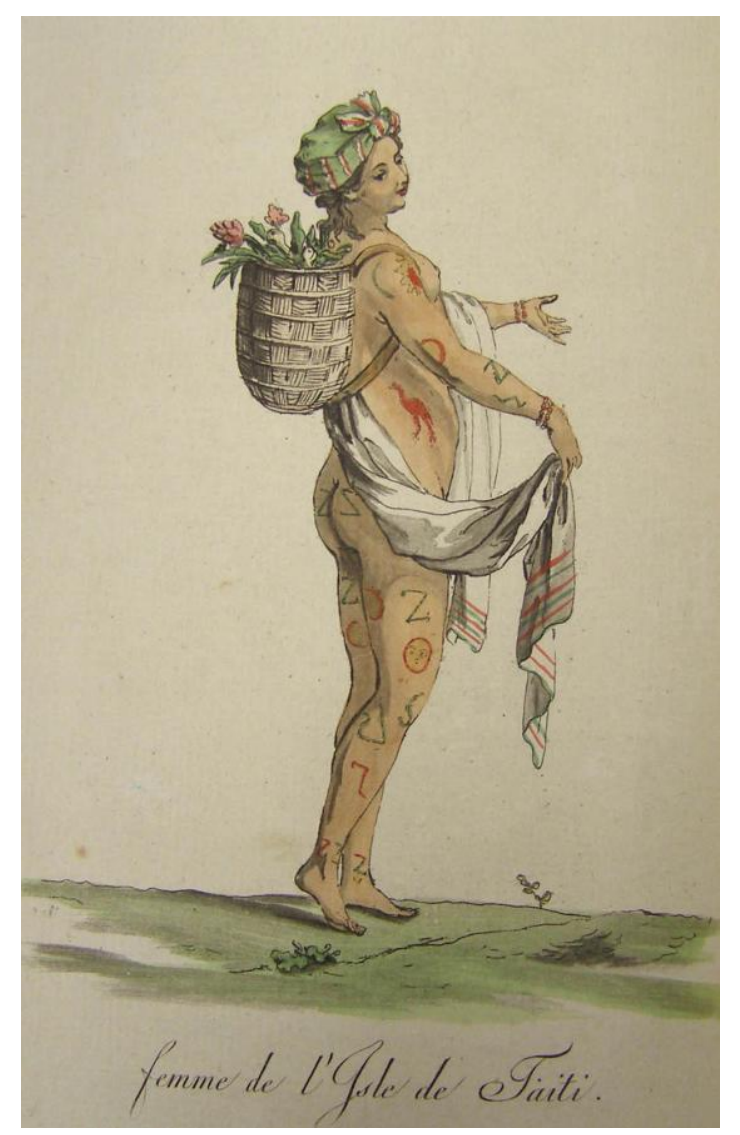

Fig 61 


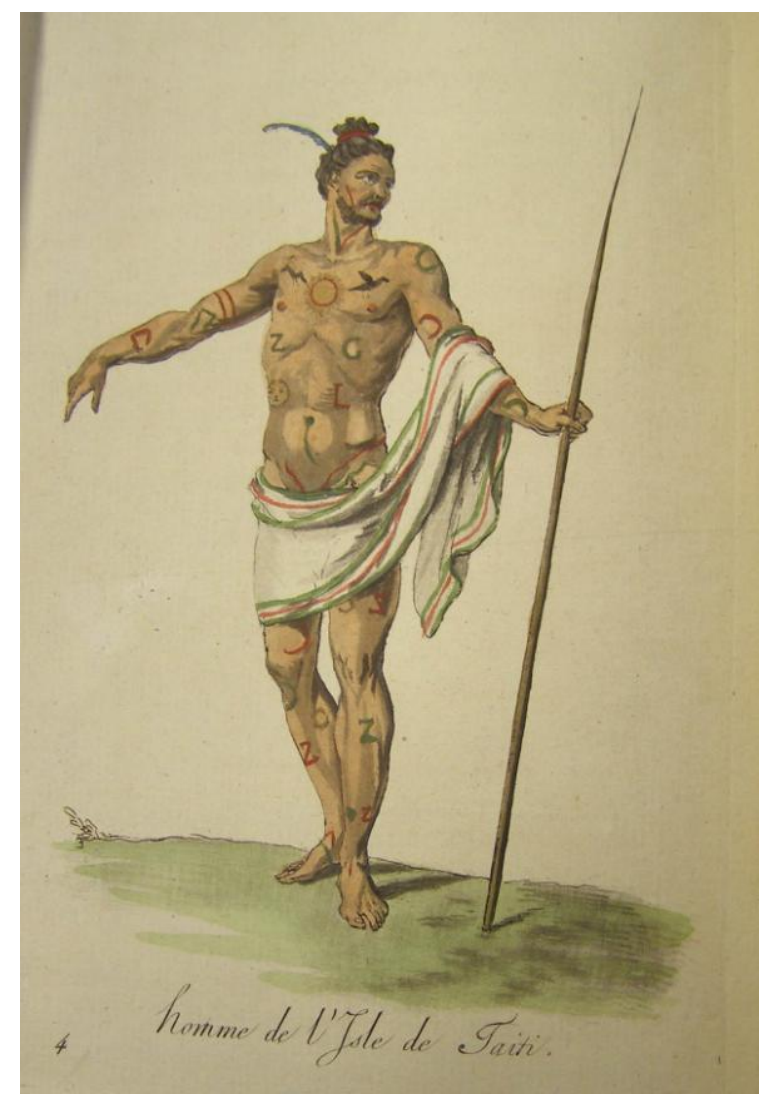

Fig 62

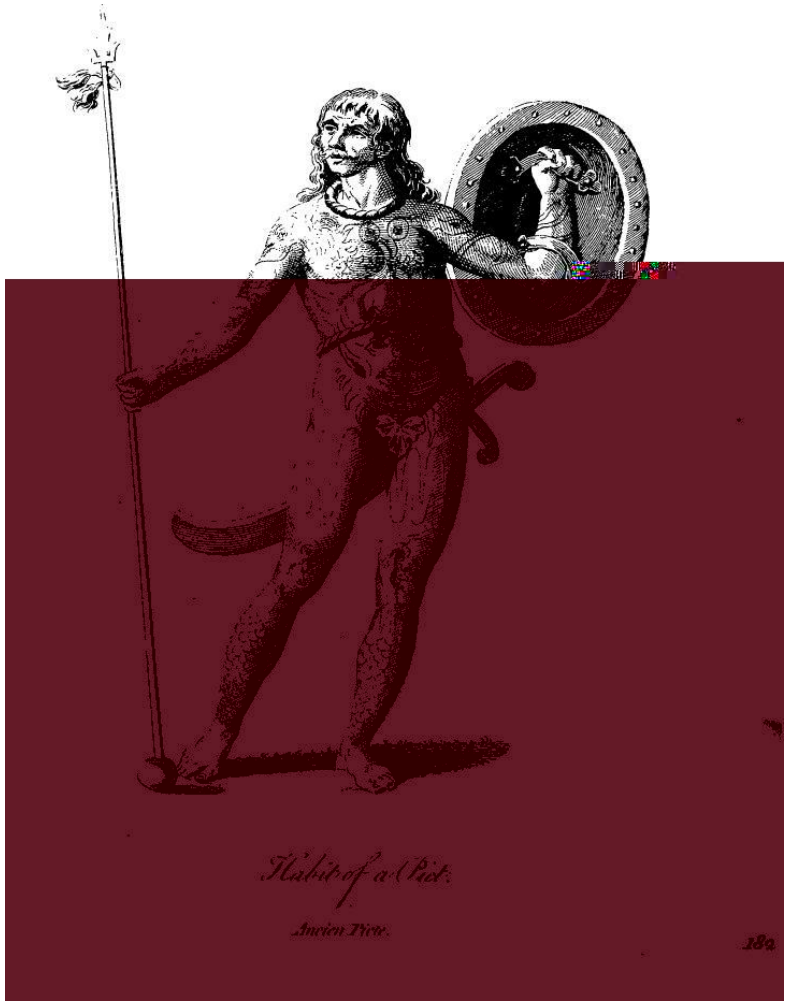

Fig 63 


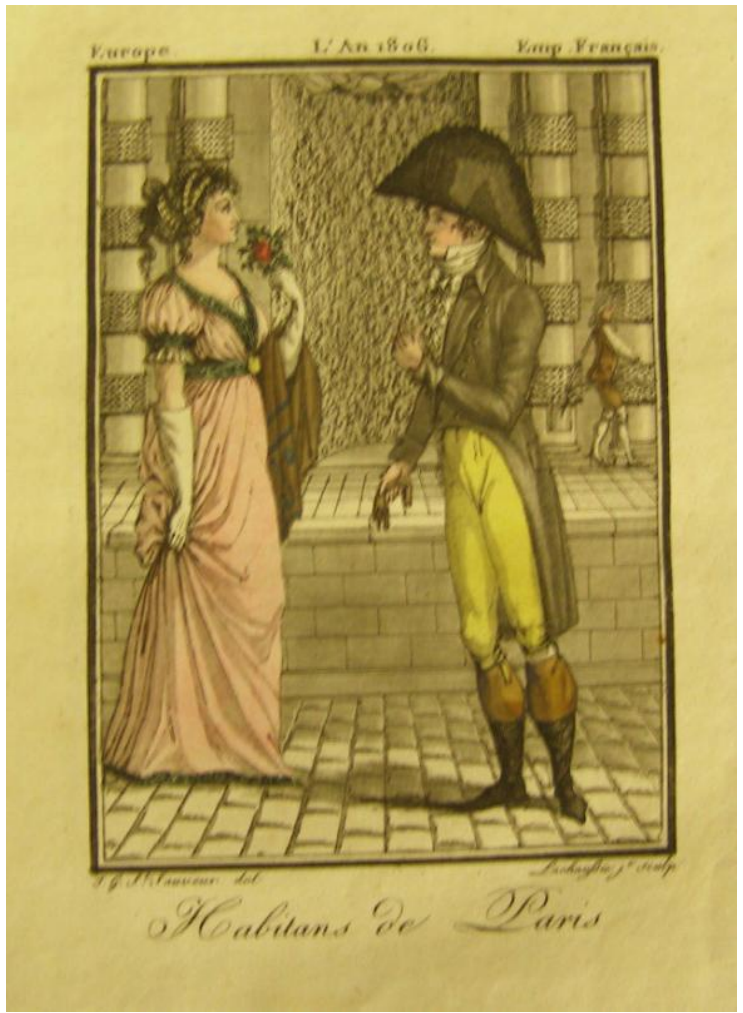

Fig 64

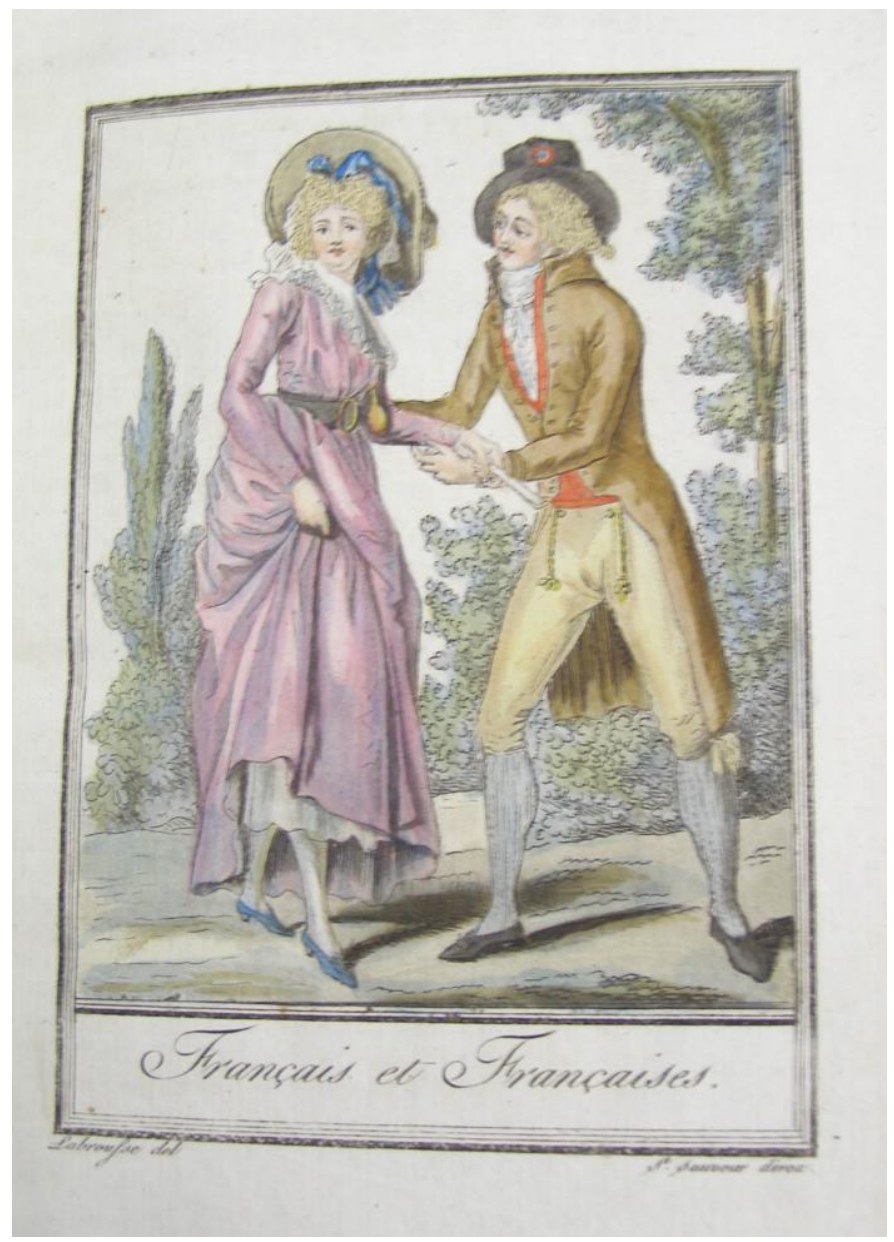

Fig 65 


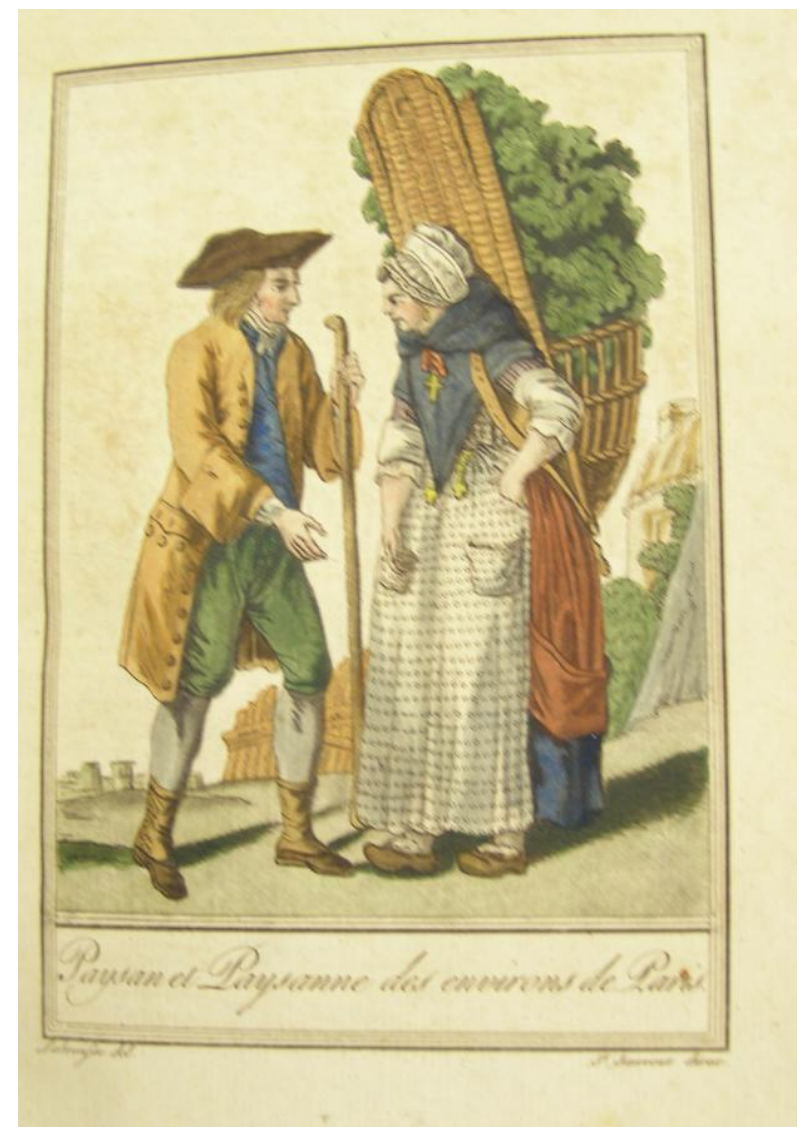

Fig 66

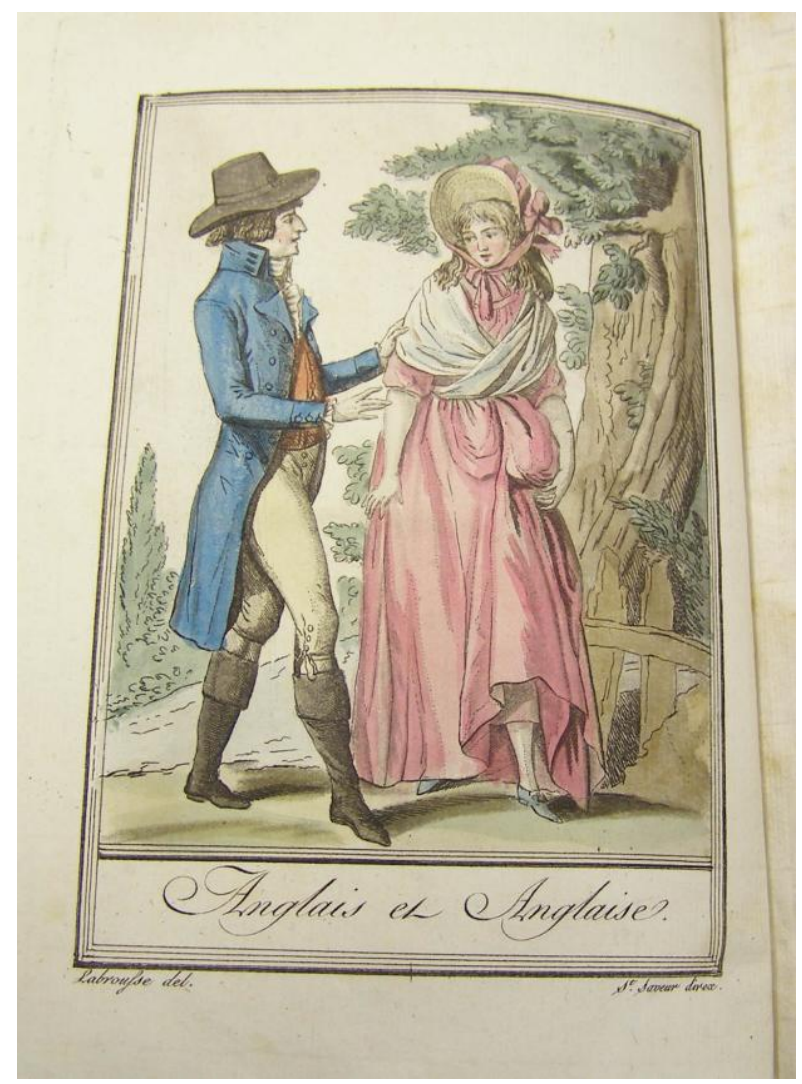

Fig 67 


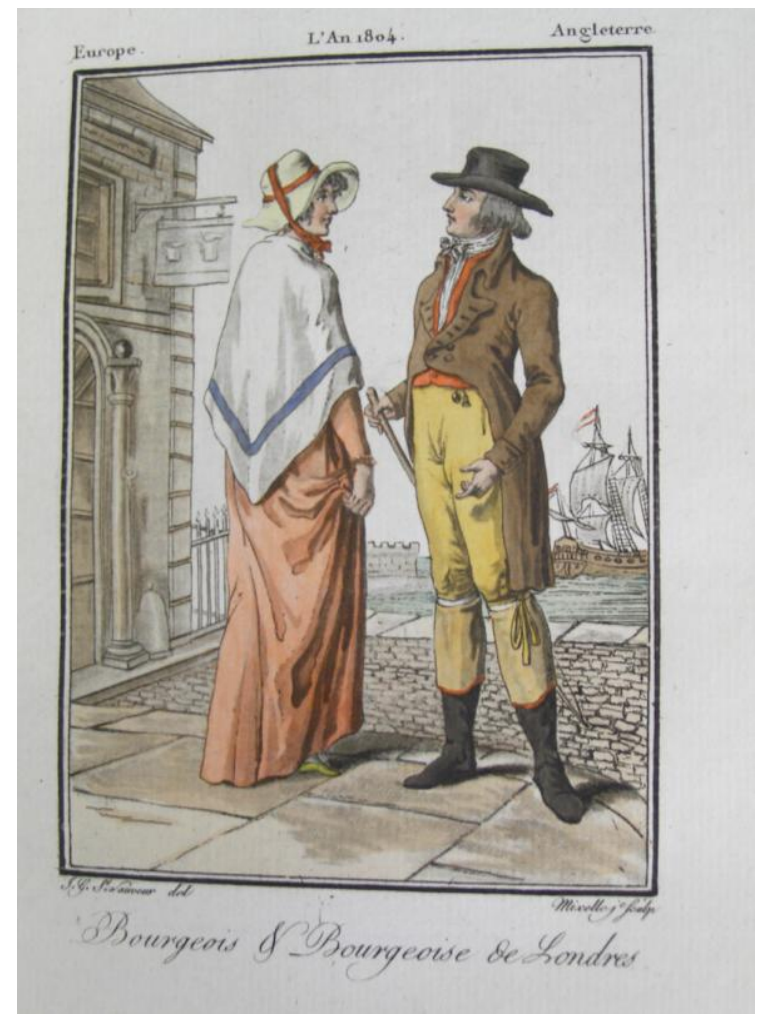

Fig 68

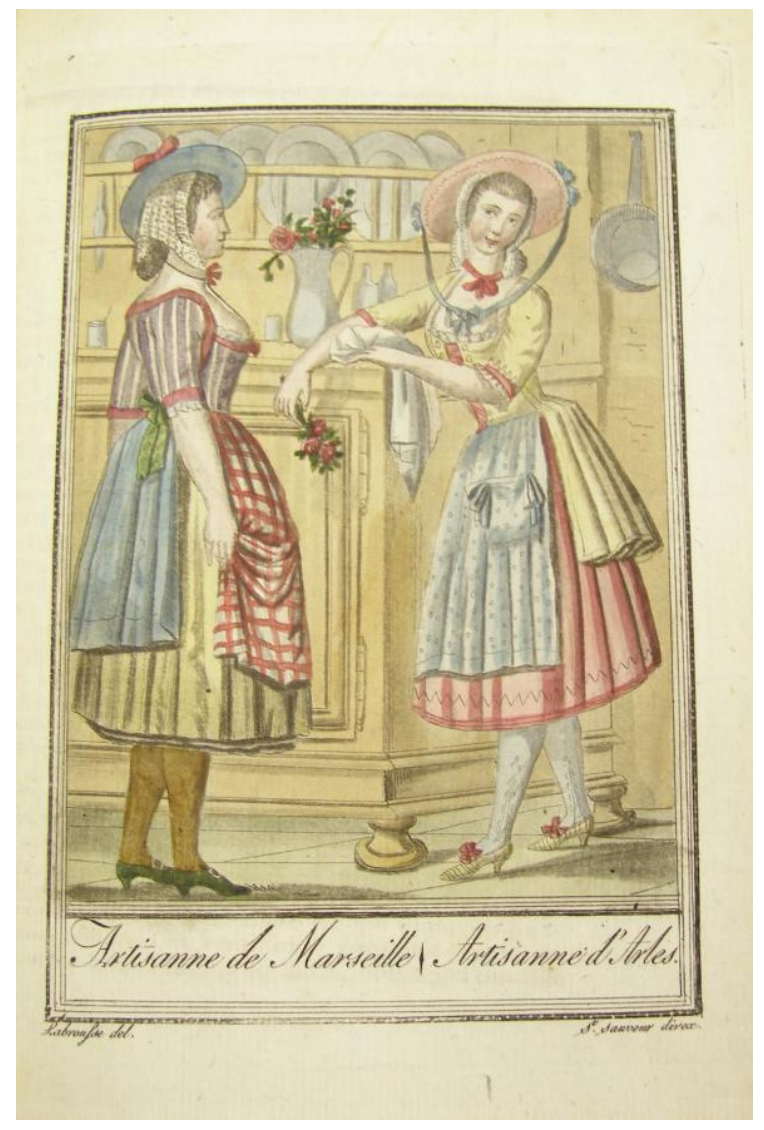

Fig 69 


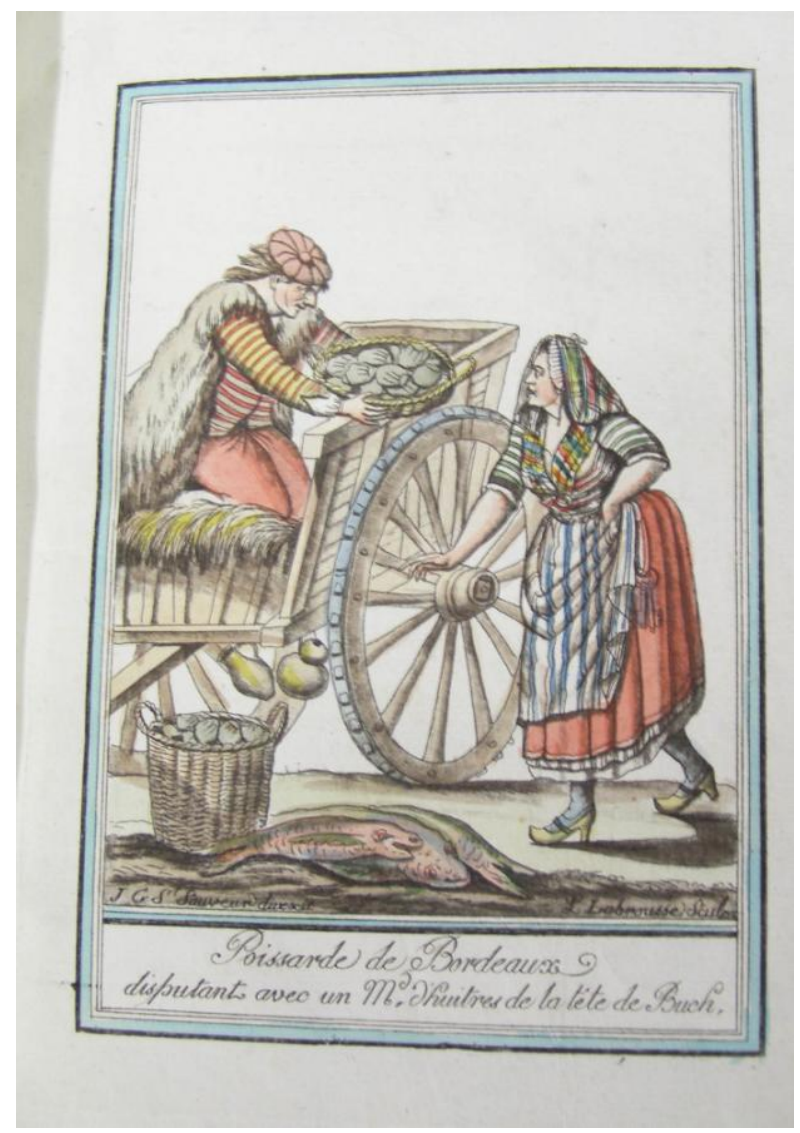

Fig 70

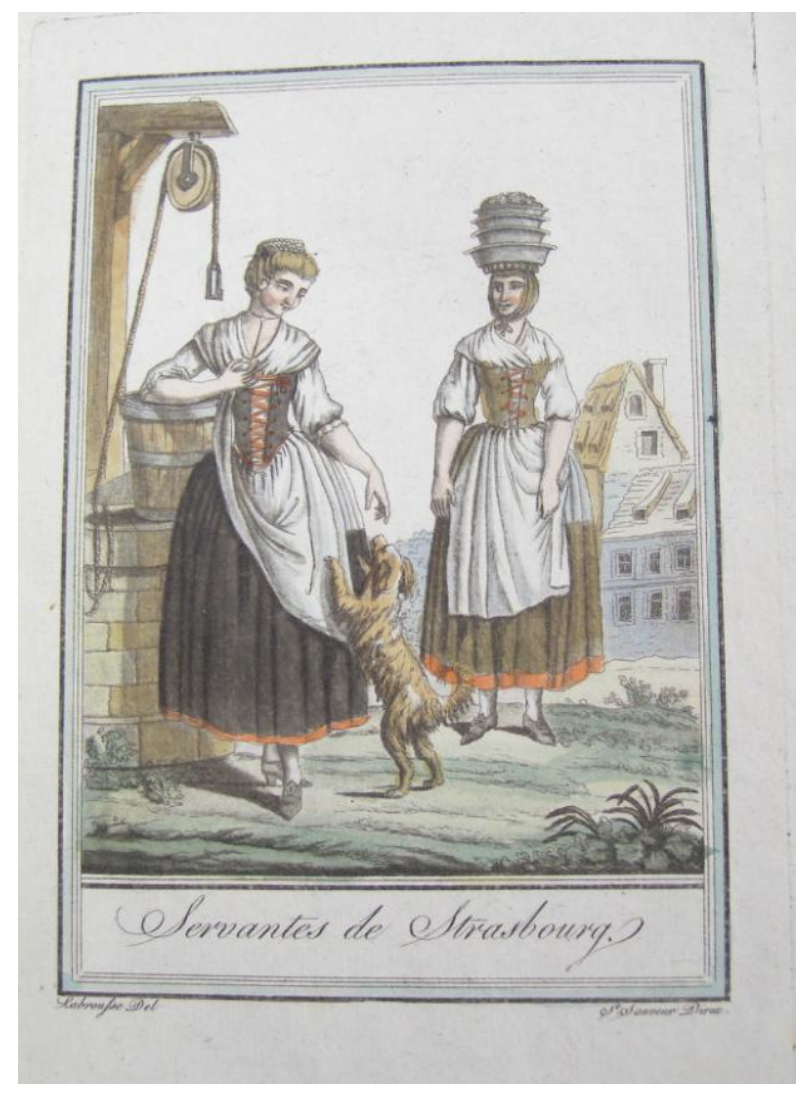

Fig 71 


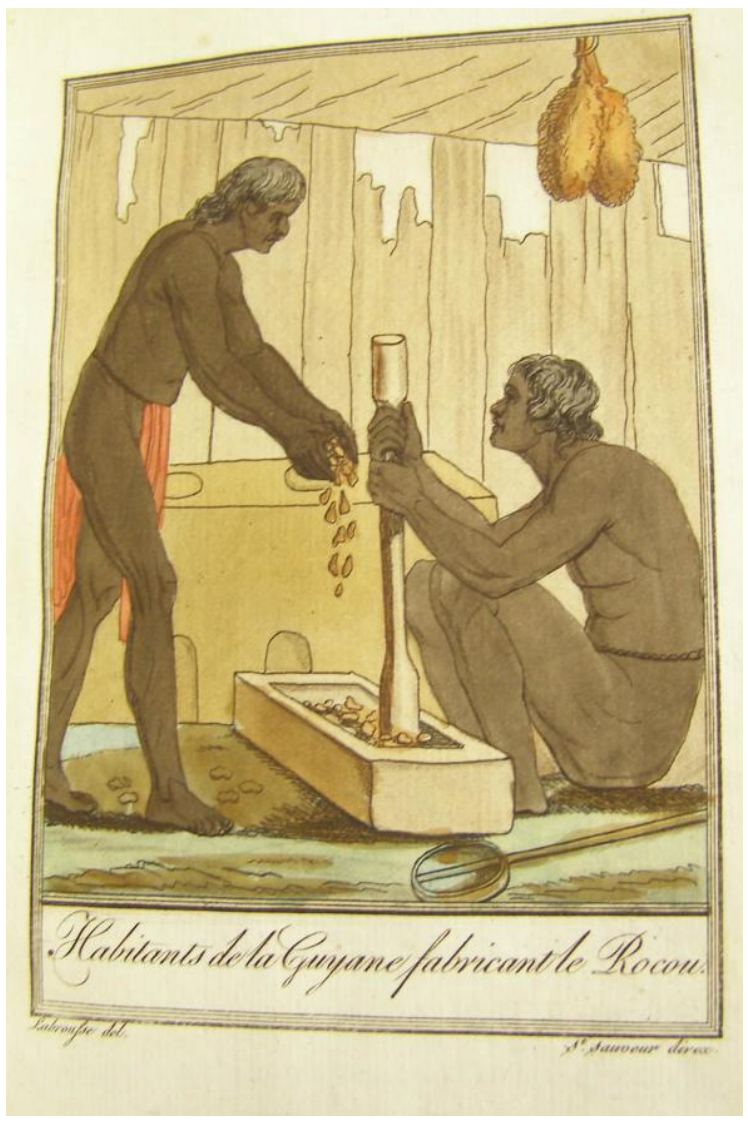

Fig 72

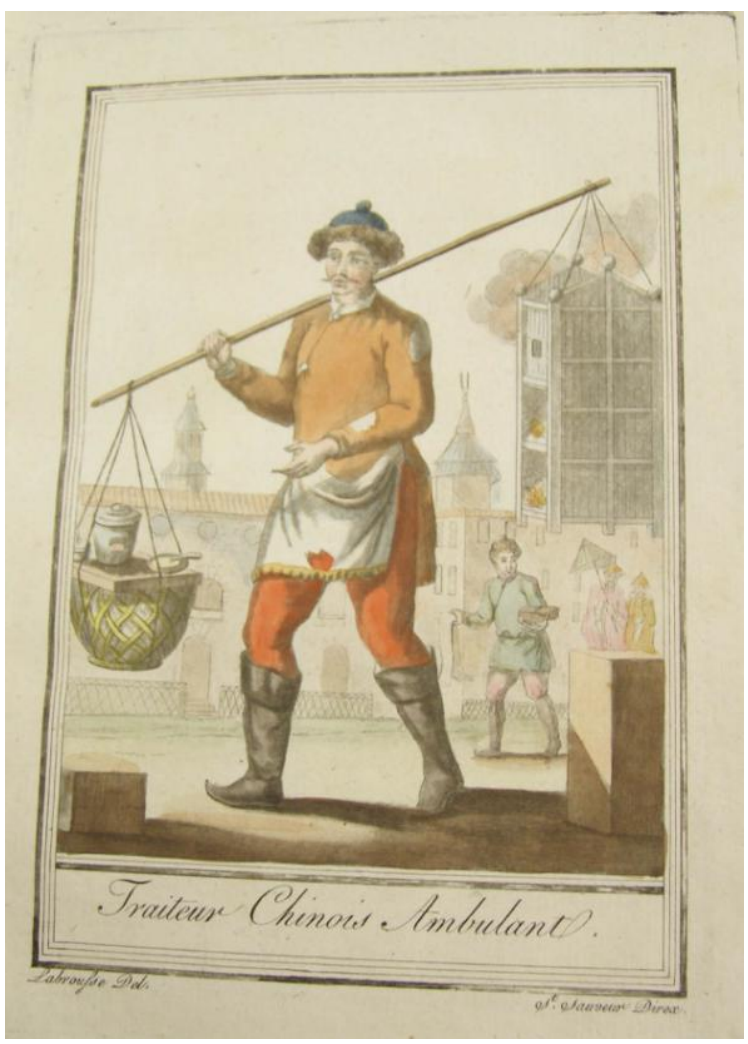

Fig 73 


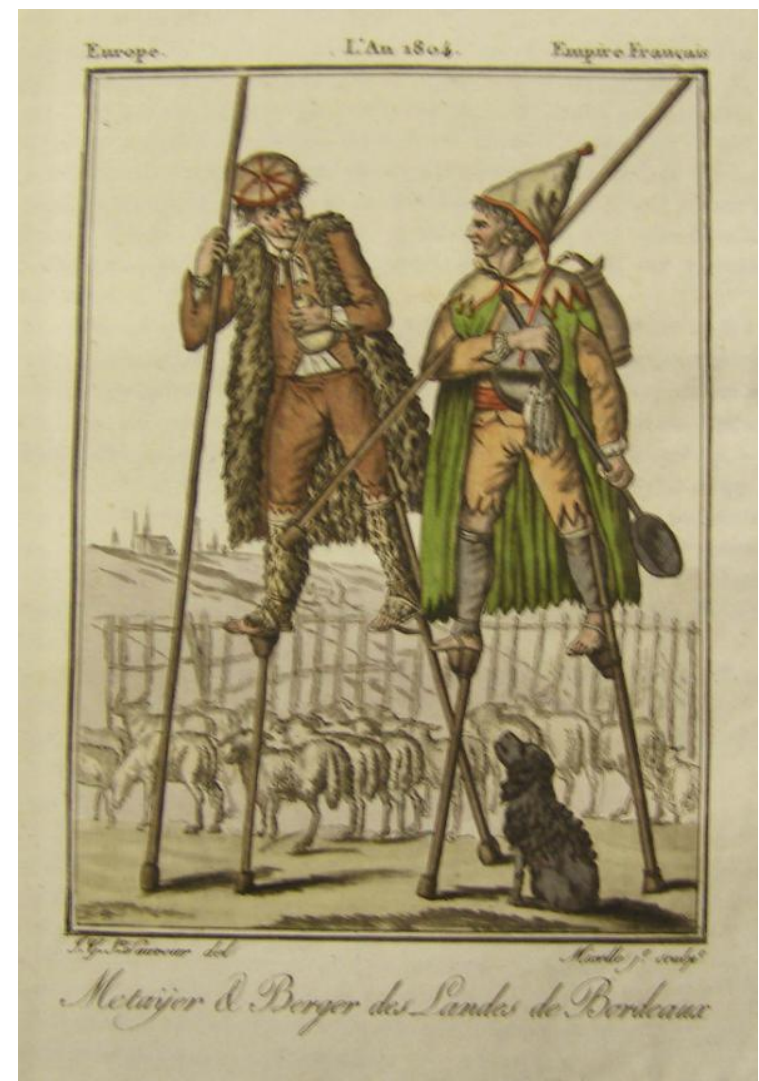

Fig 74

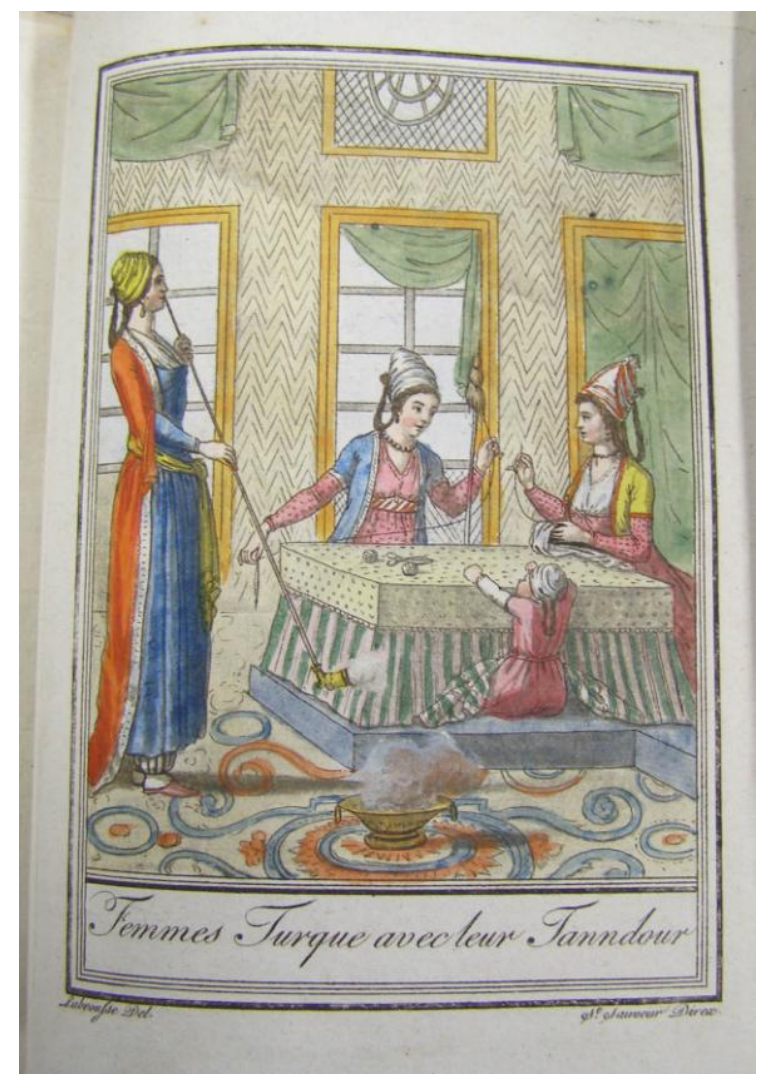

Fig 75. 


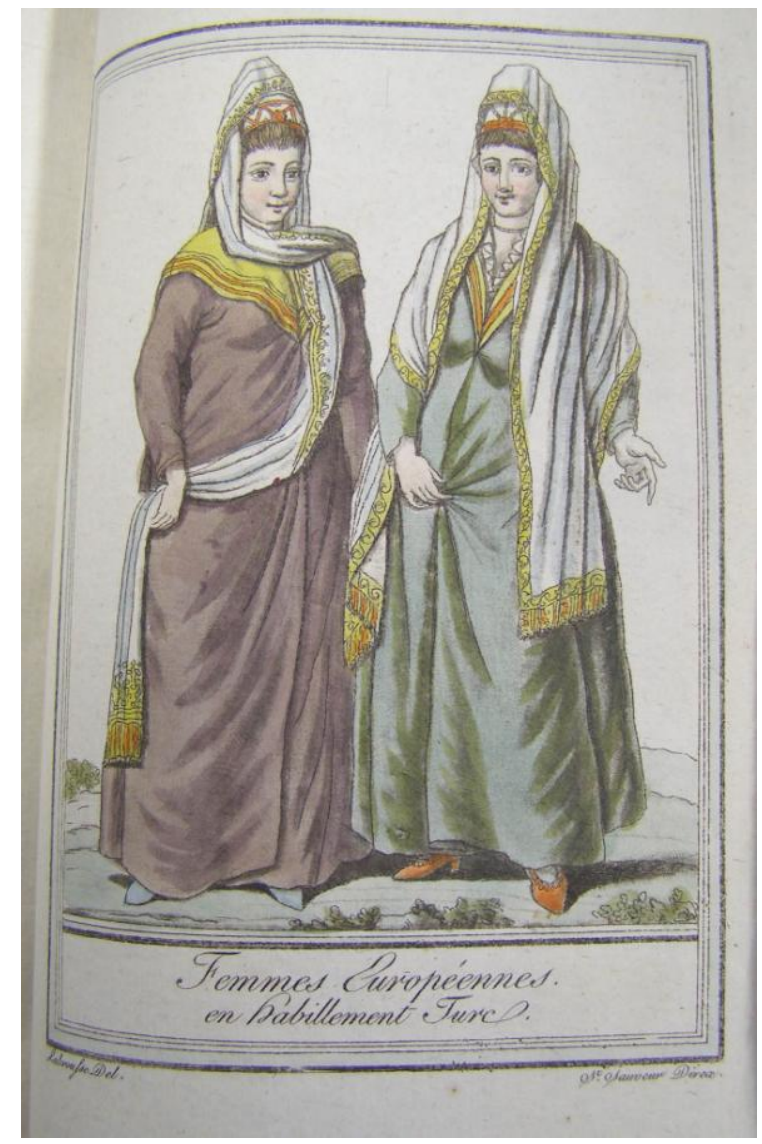

Fig 76

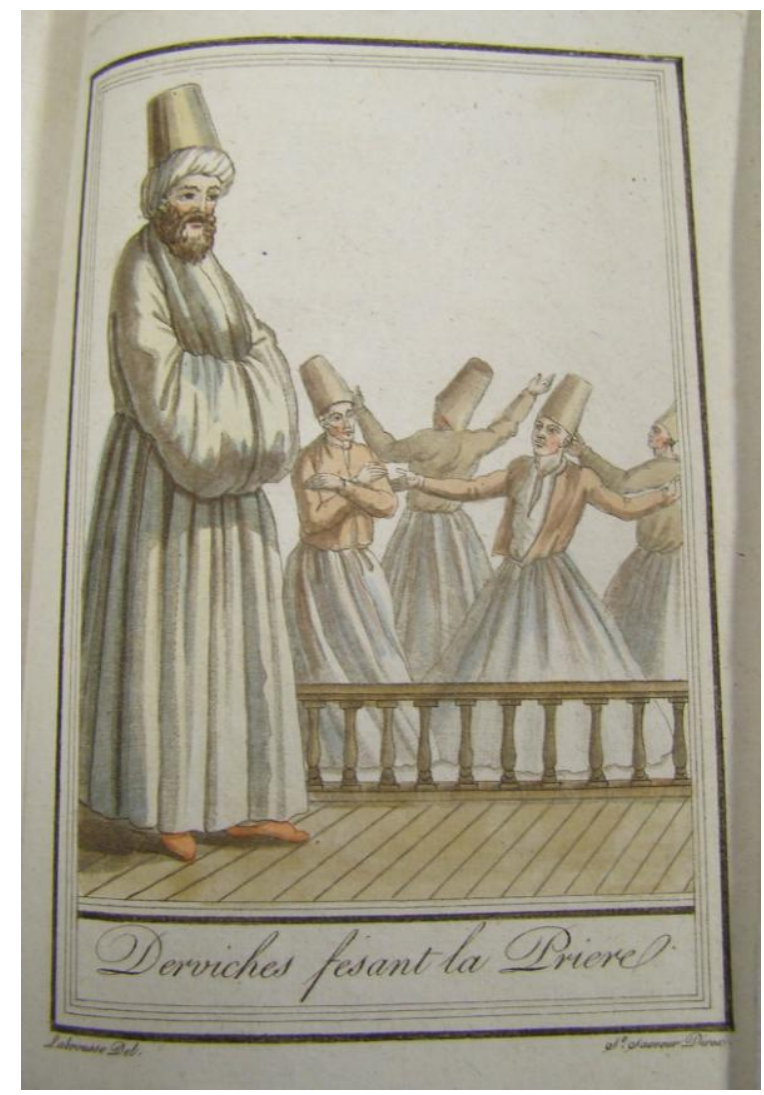

Fig 77 


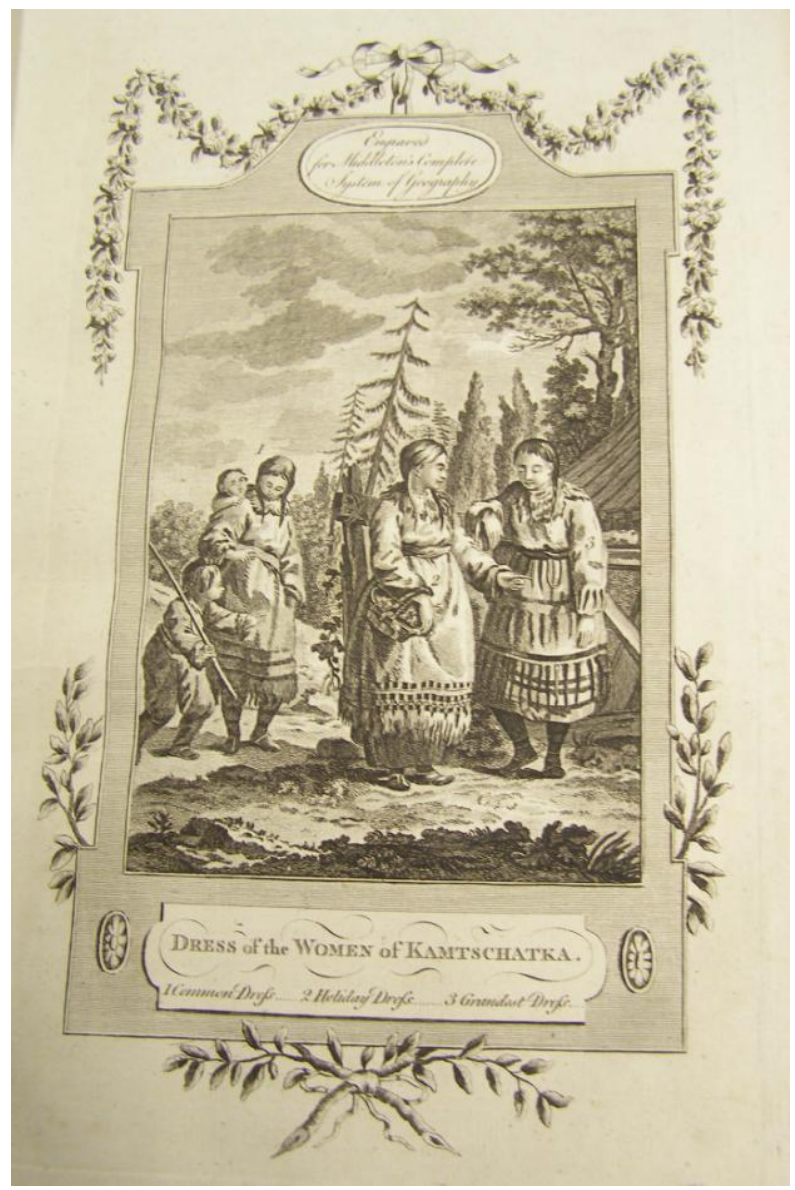

Fig 78

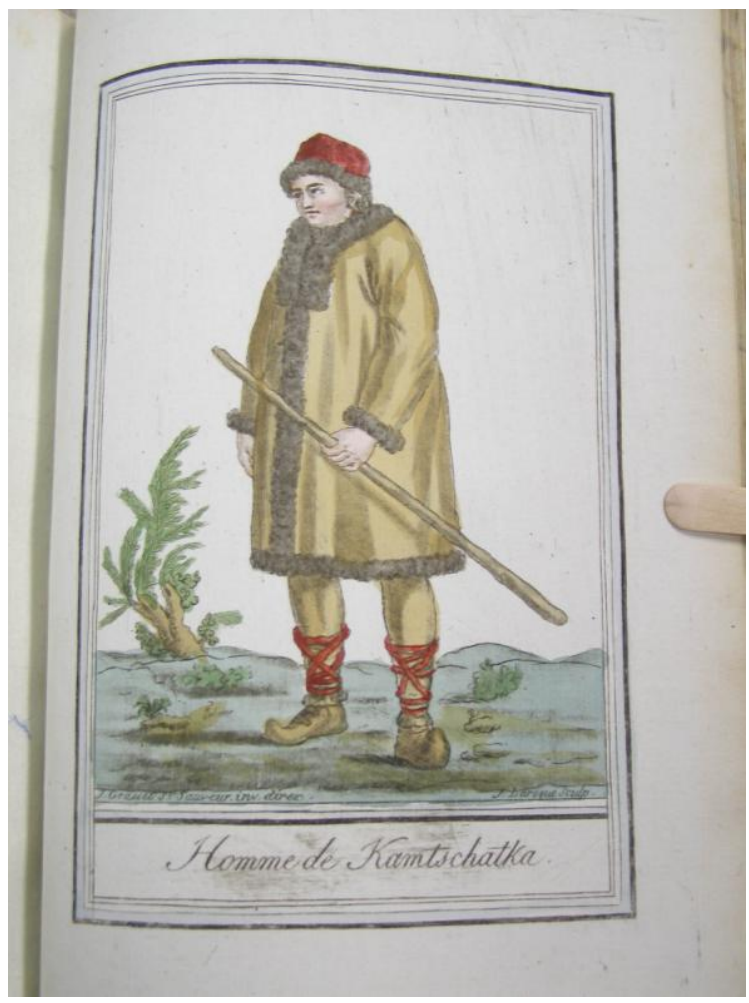

Fig 79 


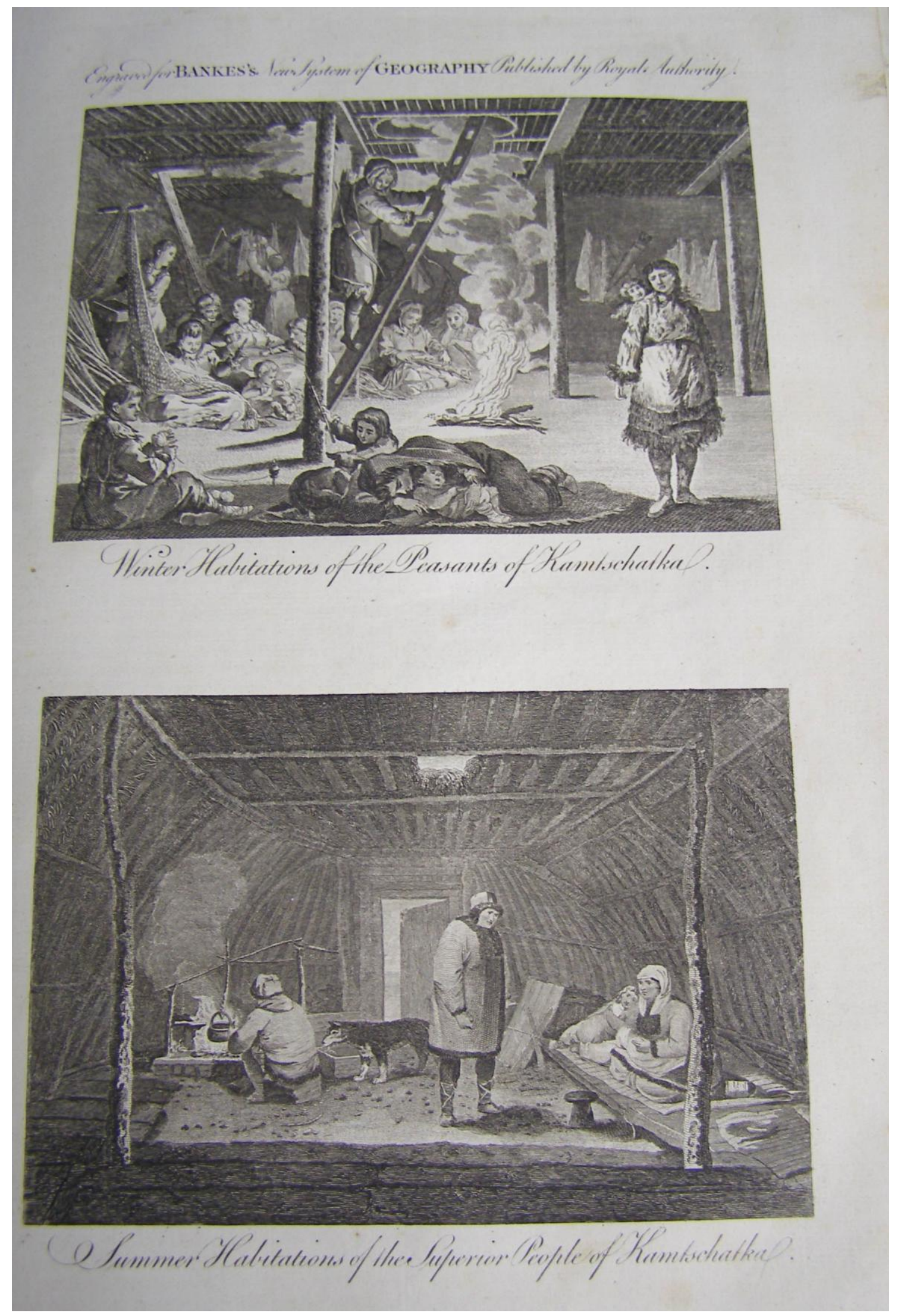

Fig 80 


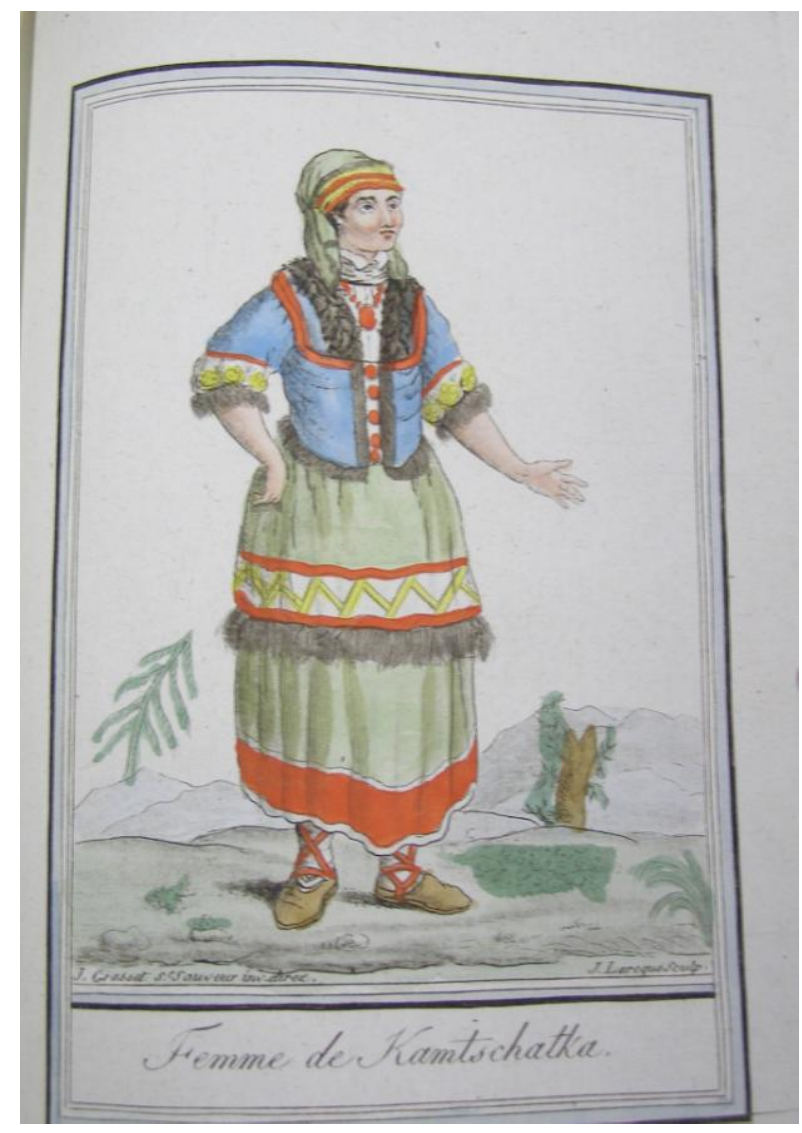

Fig 81

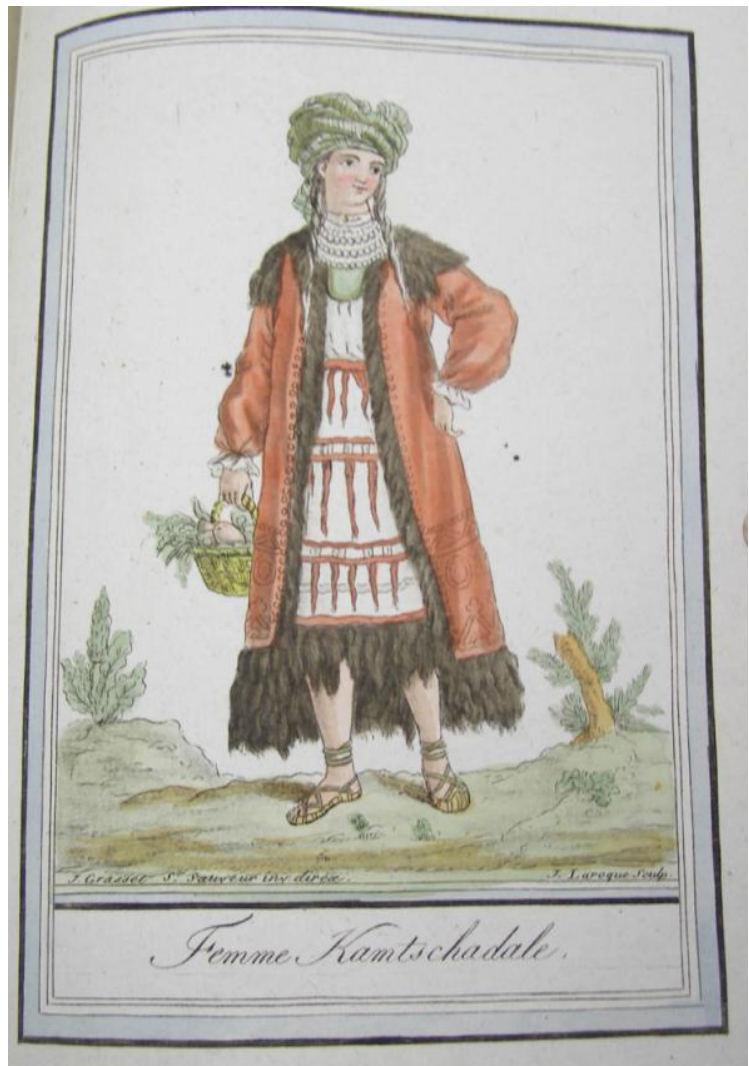

Fig 82 


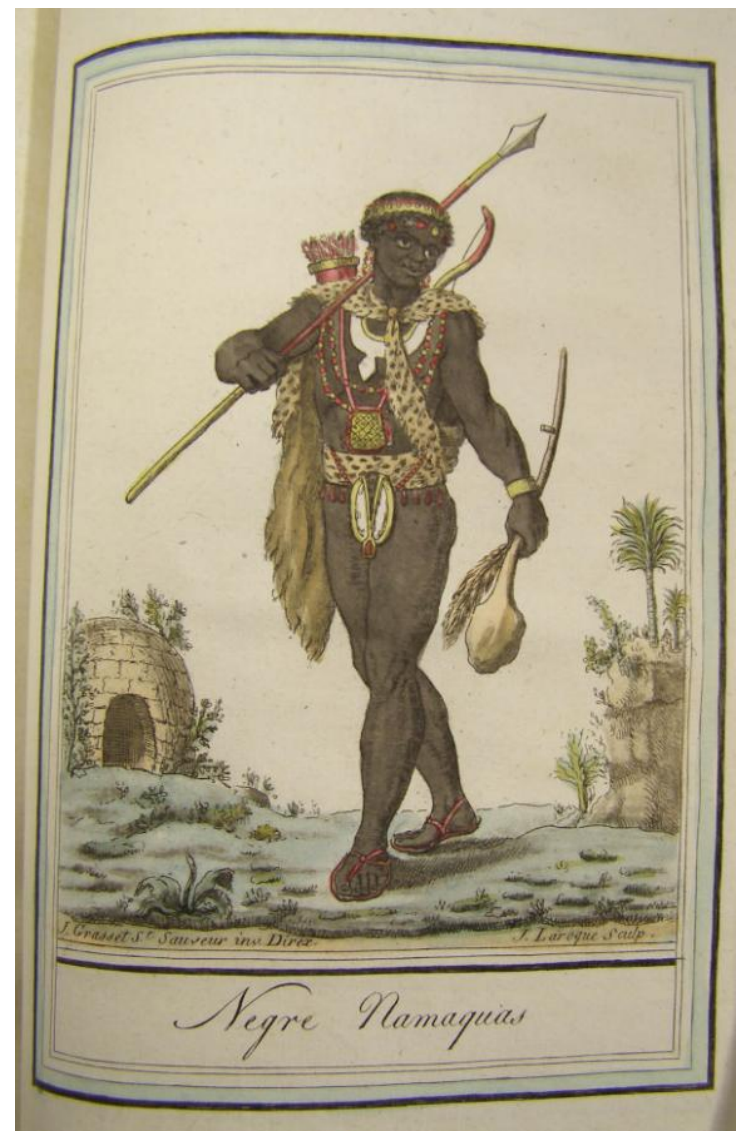

Fig 83

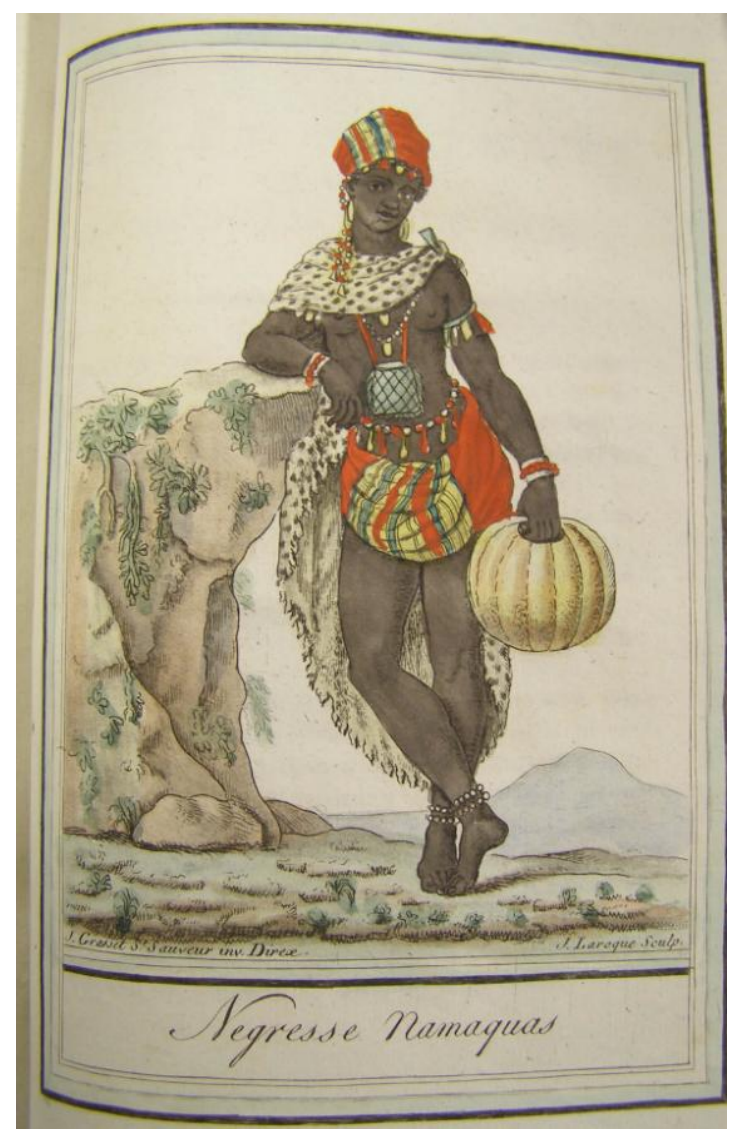

Fig 84 


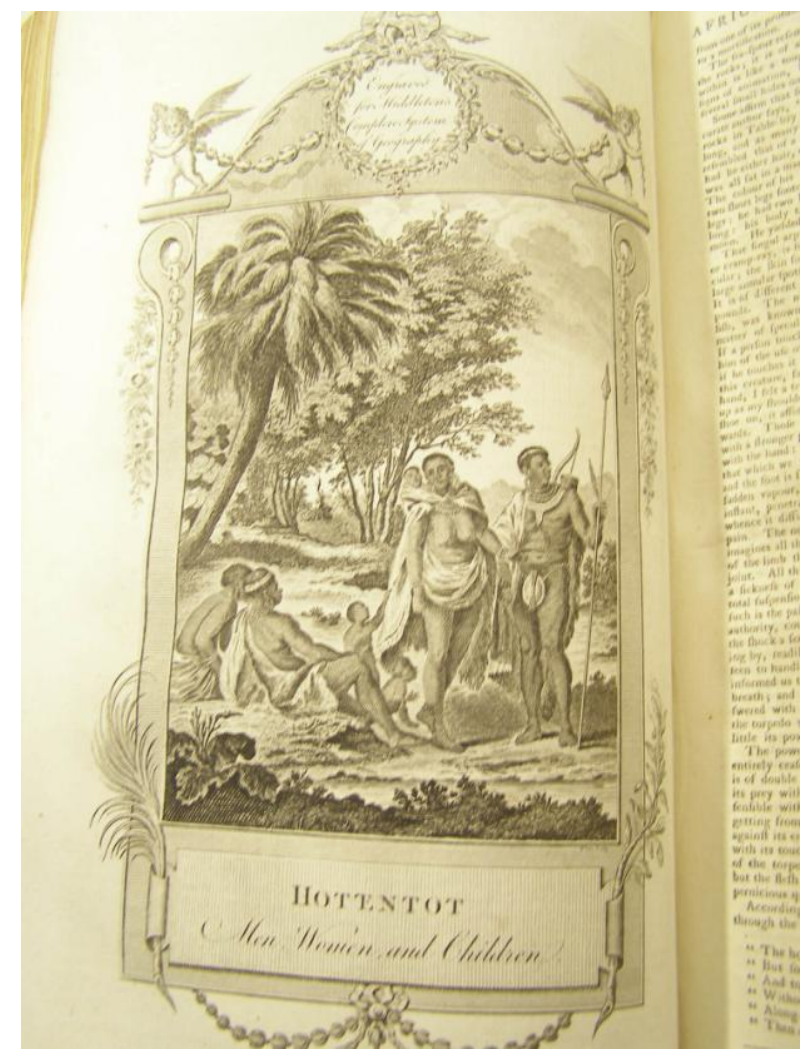

Fig 85

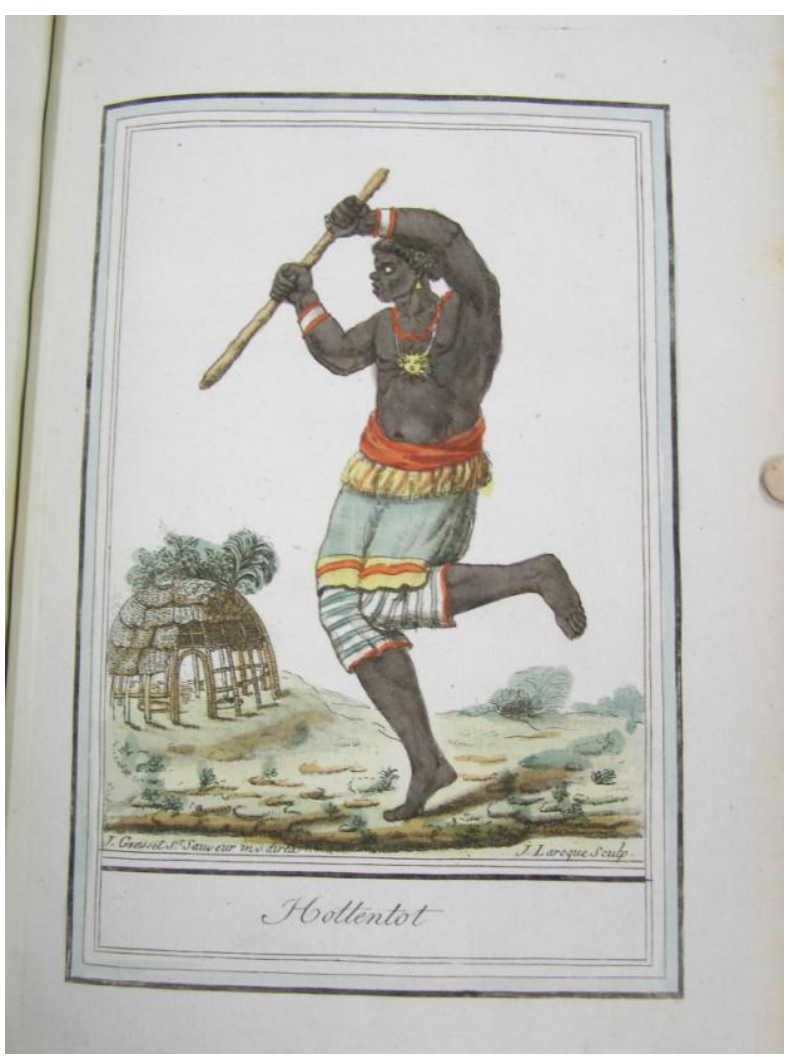

Fig 86 


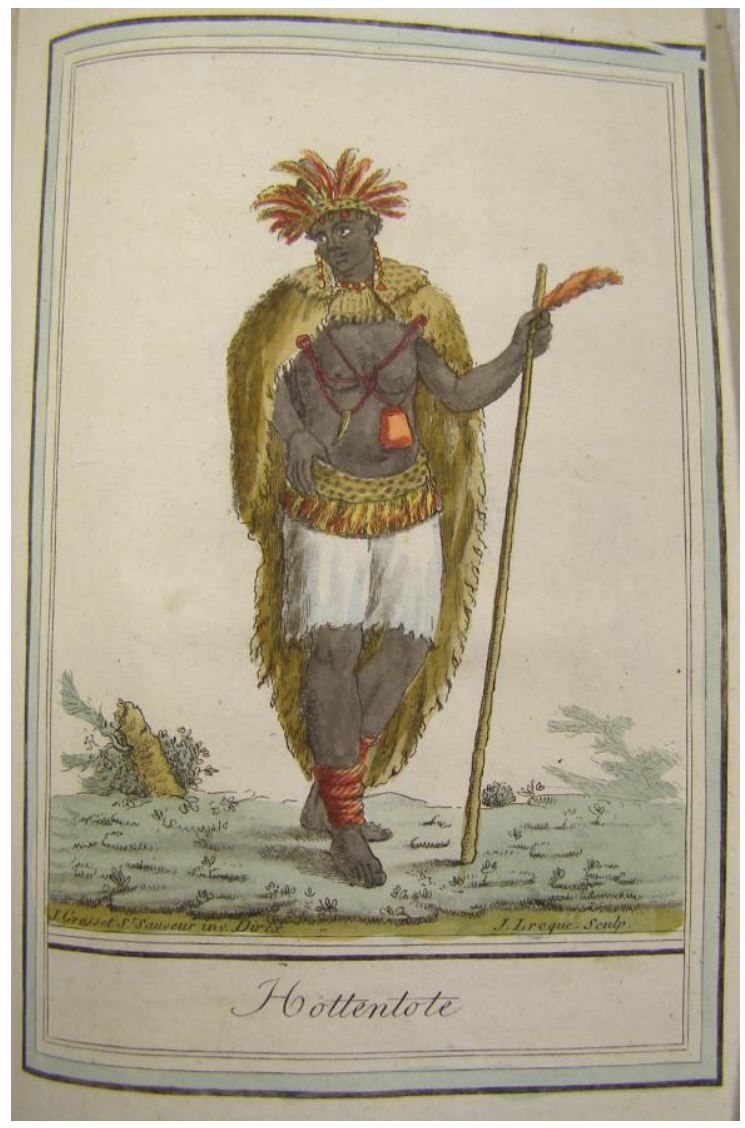

Fig 87

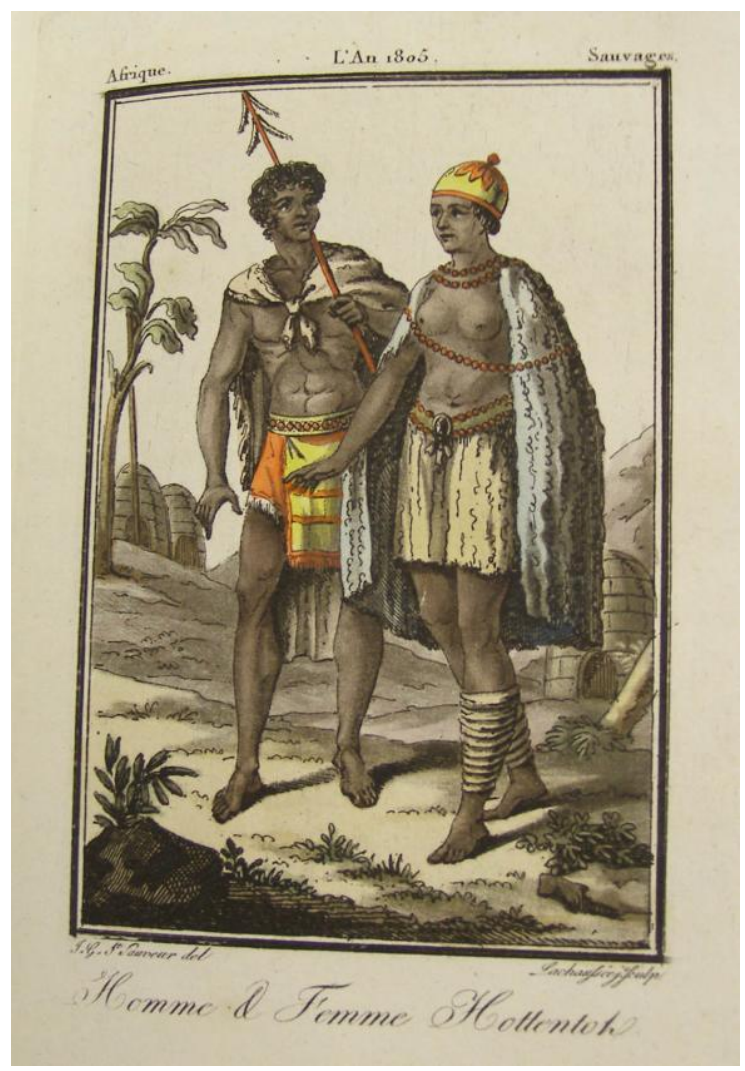

Fig 88 


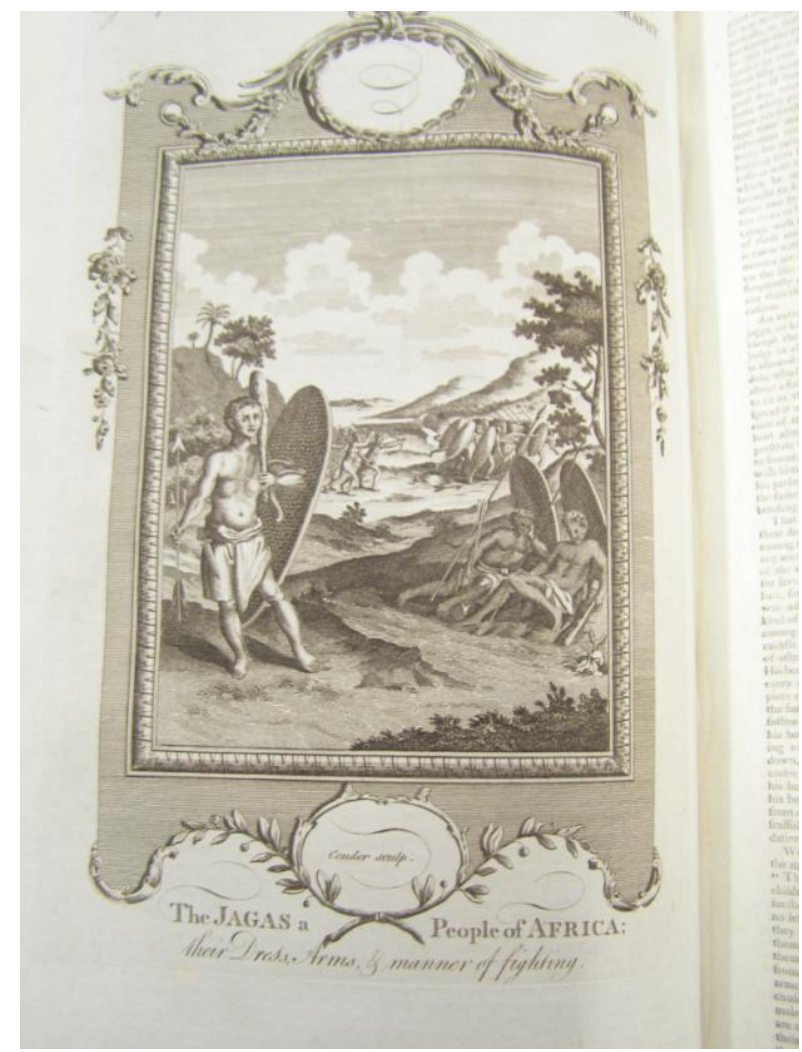

Fig 89

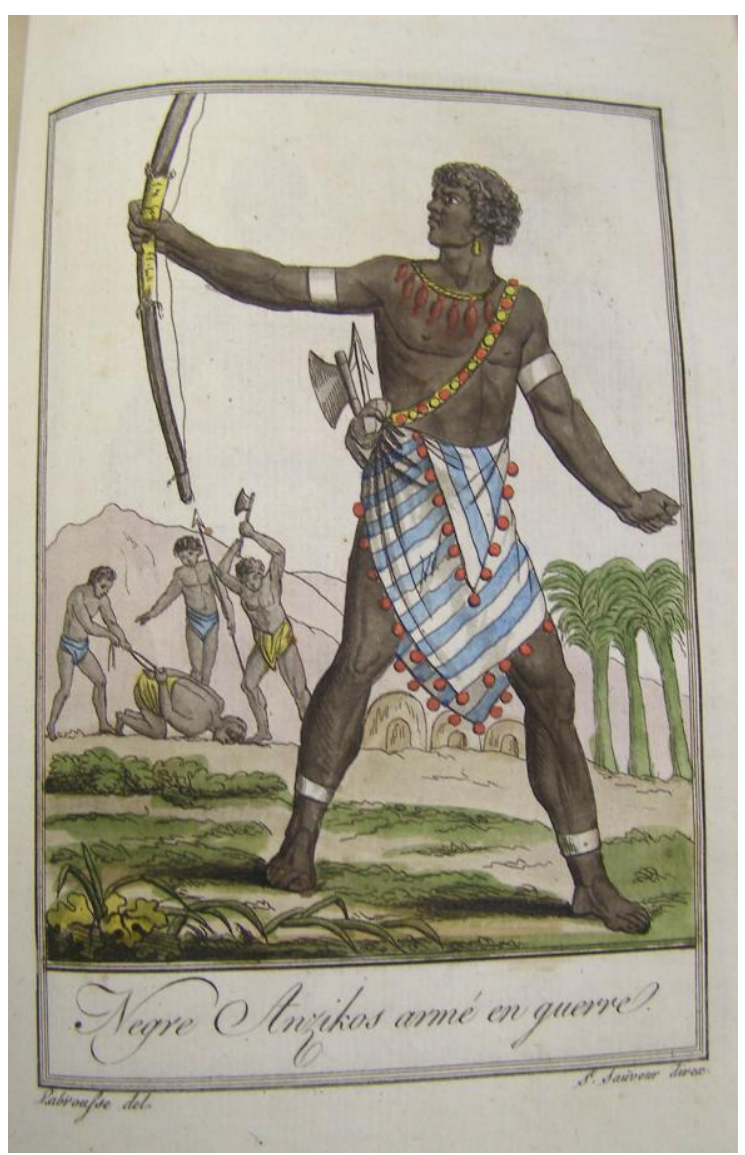

Fig 90 


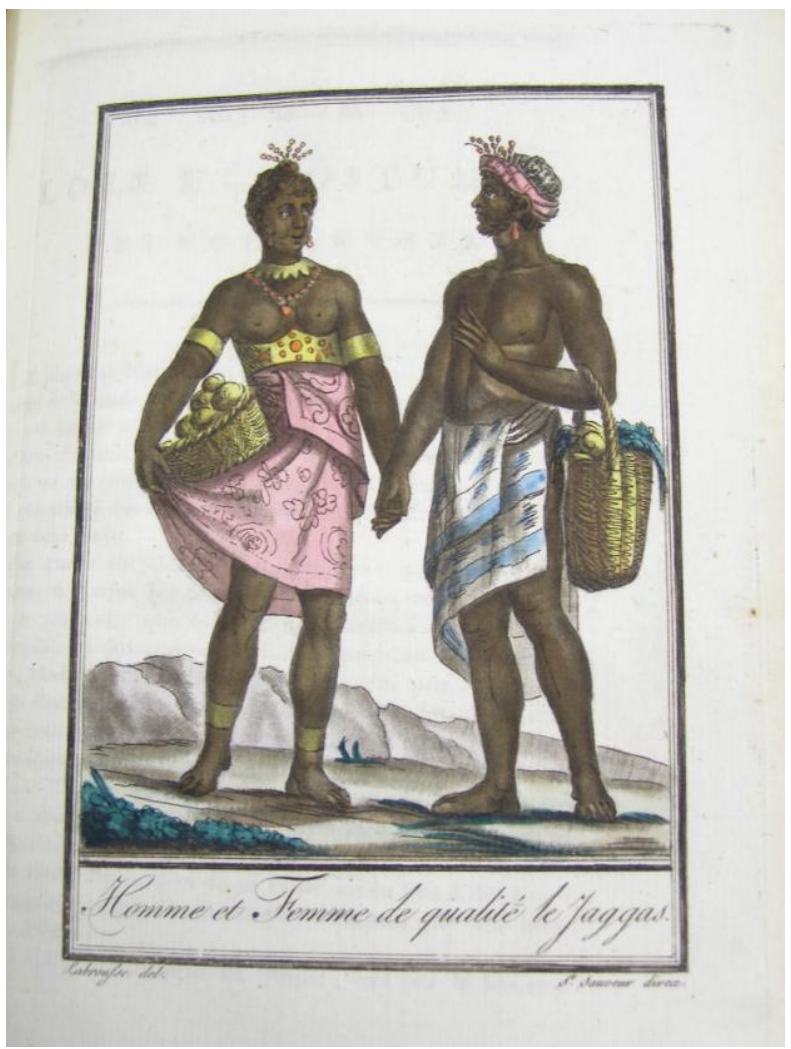

Fig 91

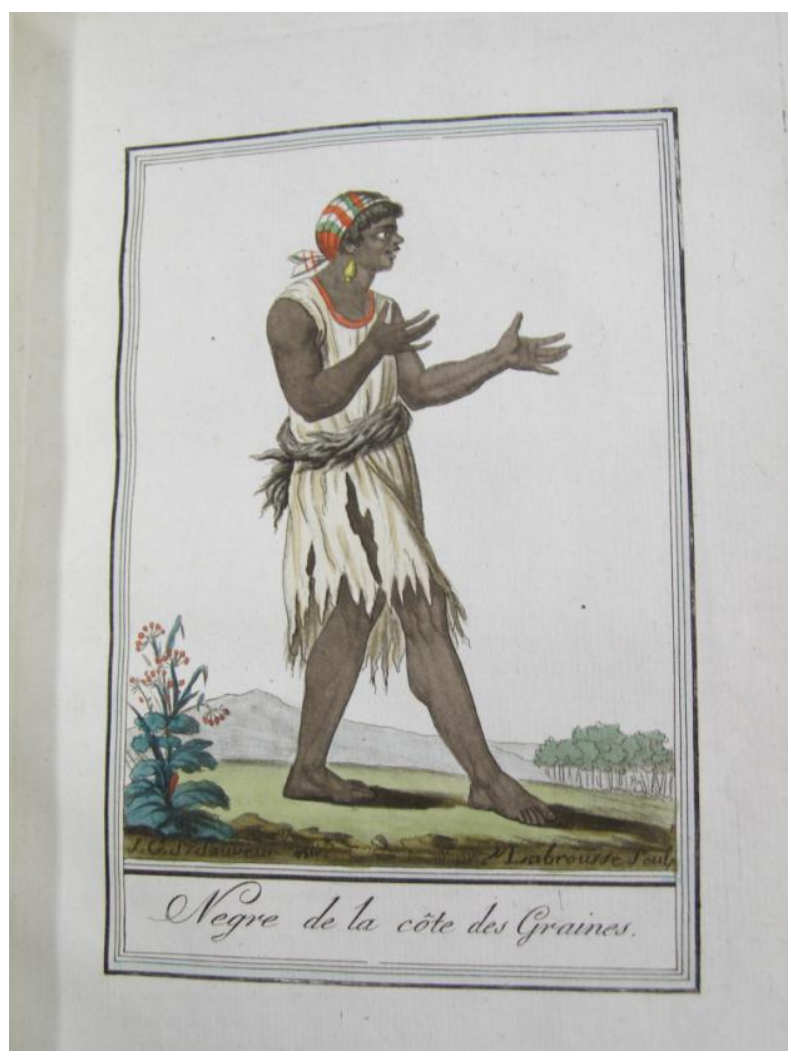

Fig 92 


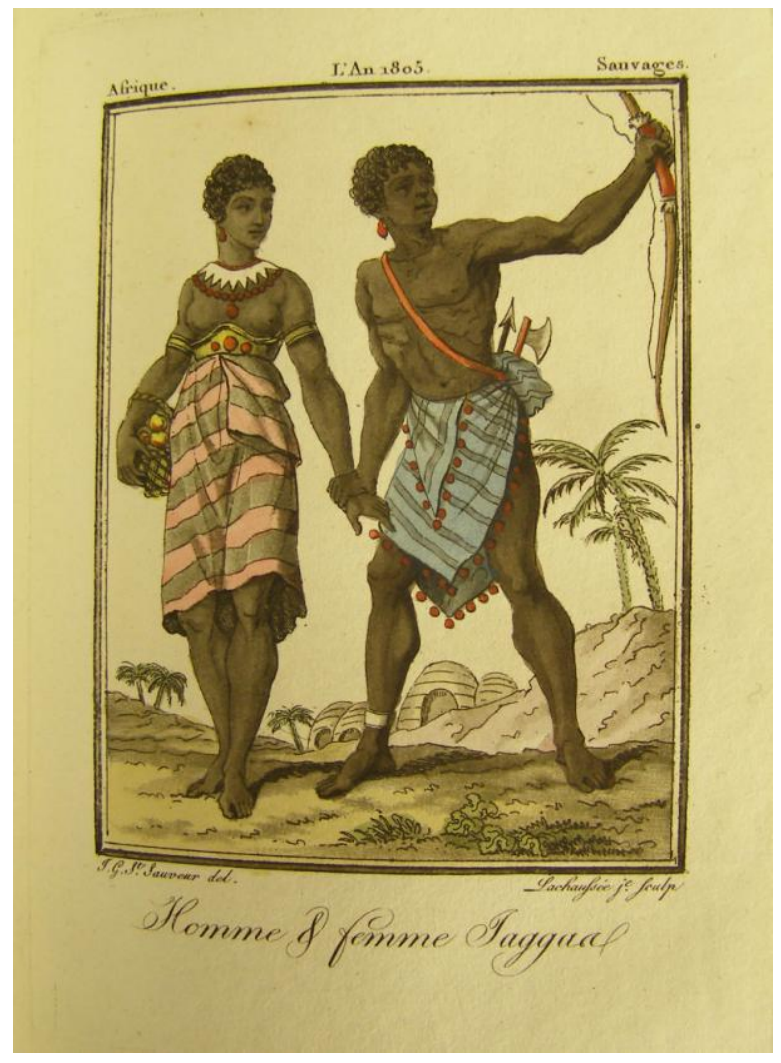

Fig 93

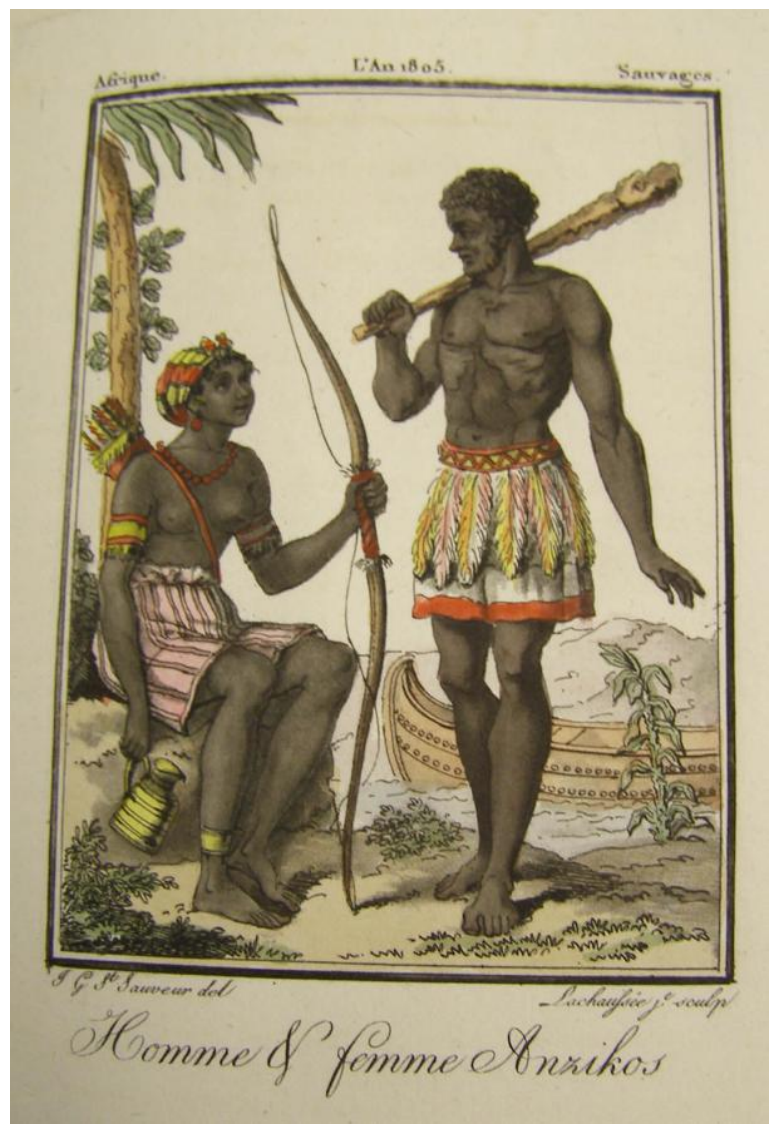

Fig 94 


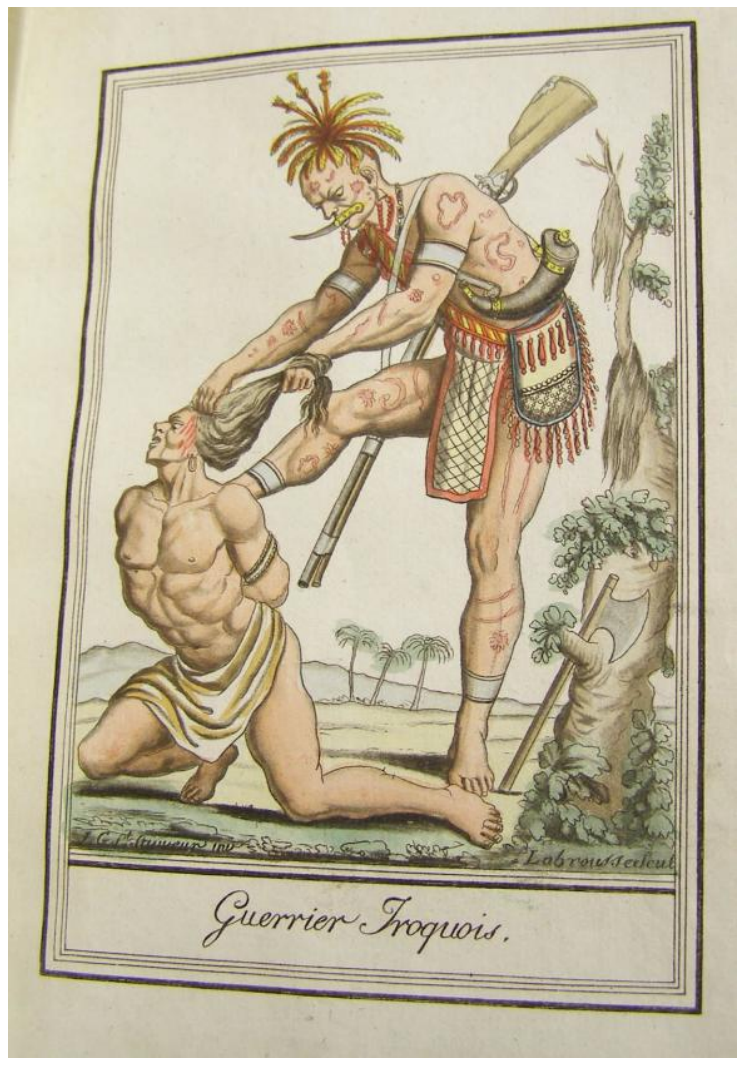

Fig 95

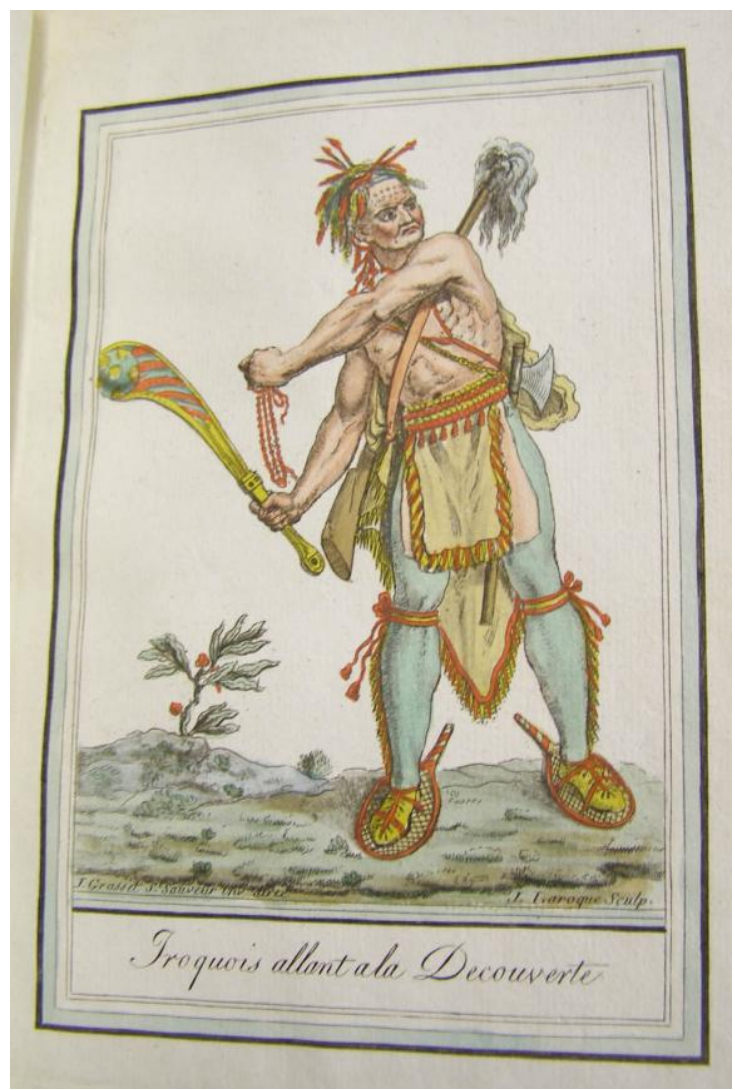

Fig 96 


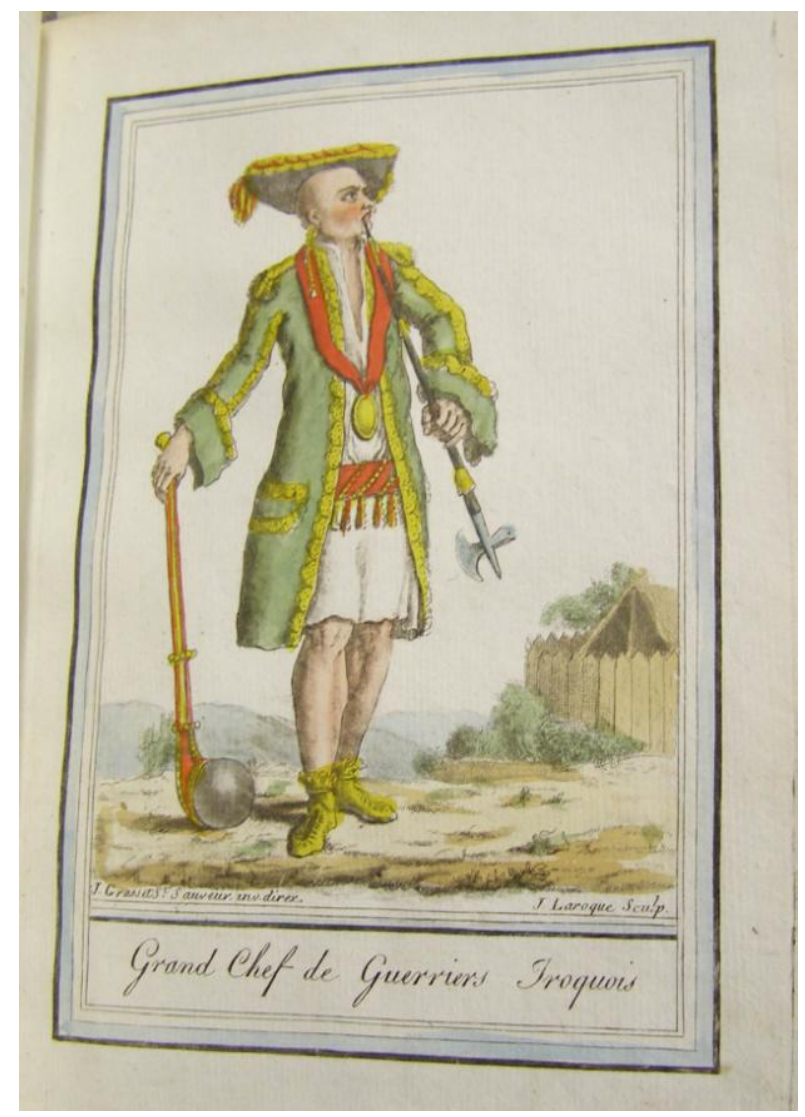

Fig 97

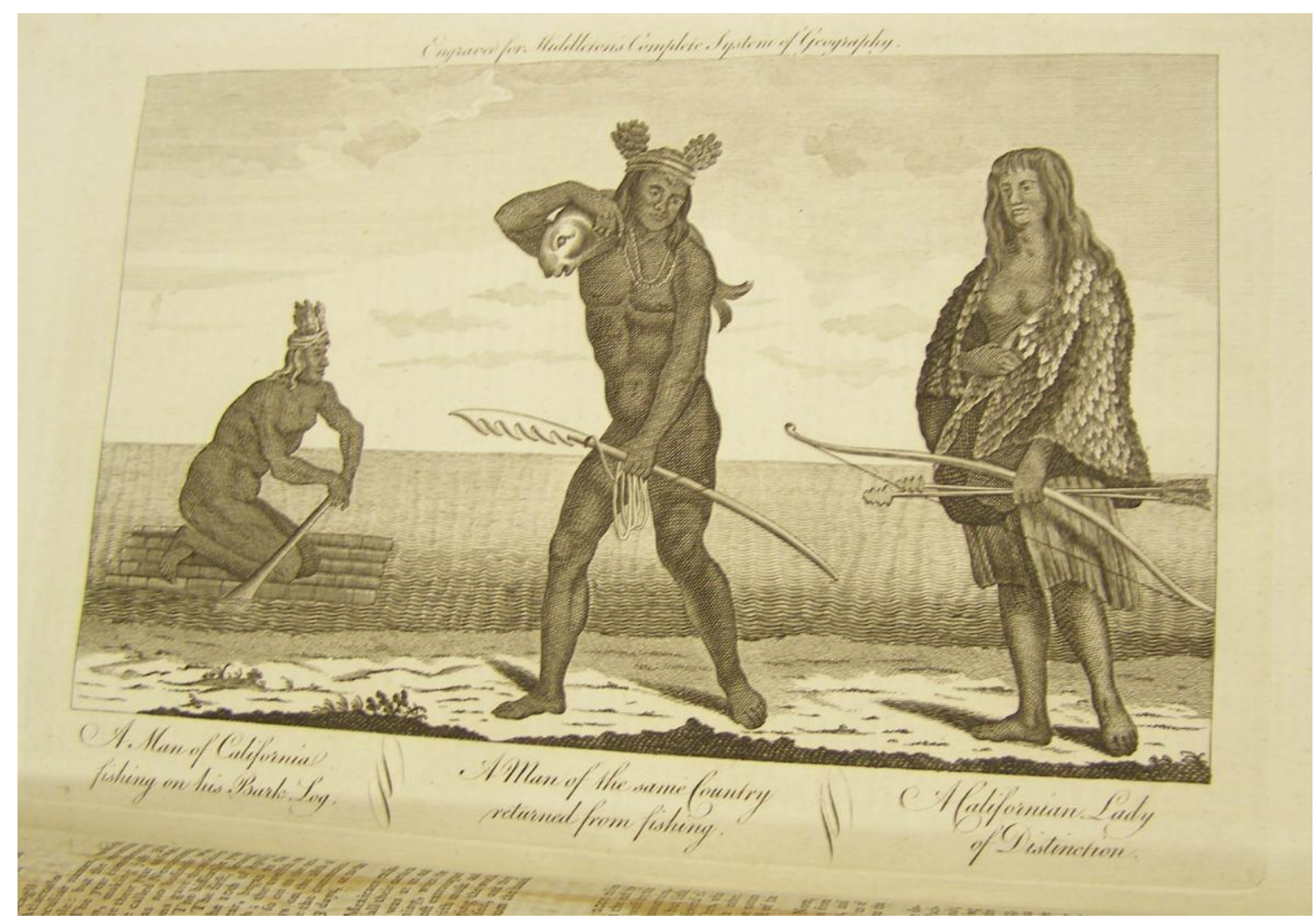

Fig 98 


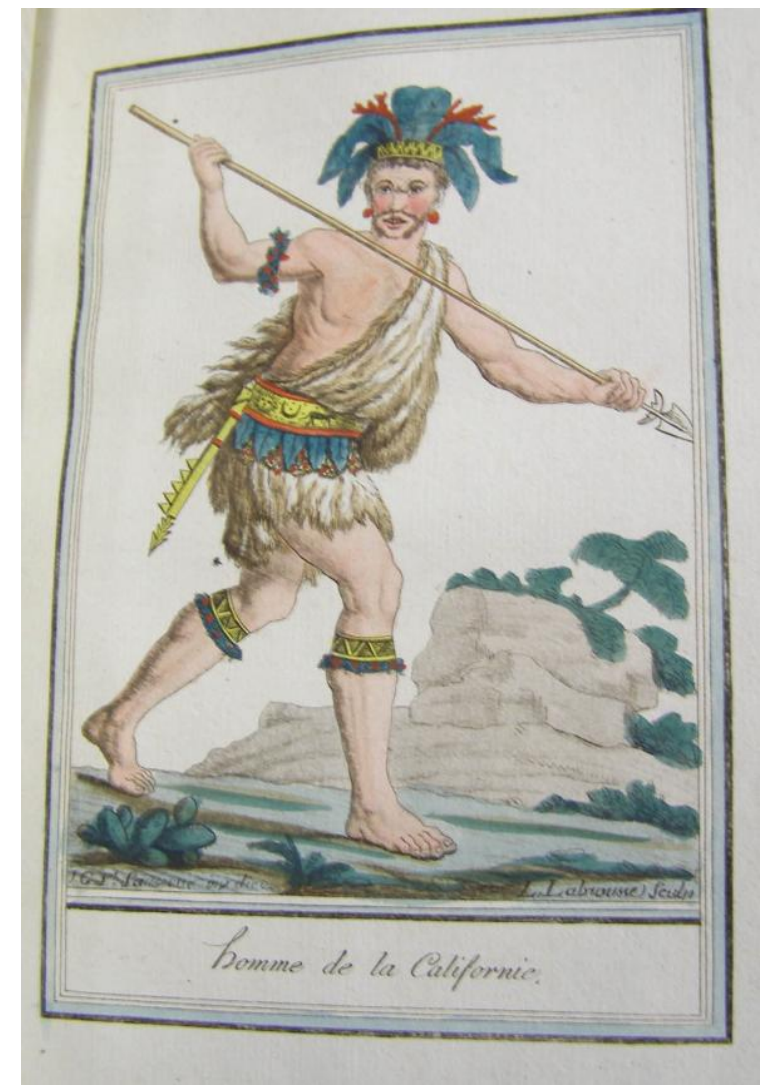

Fig 99

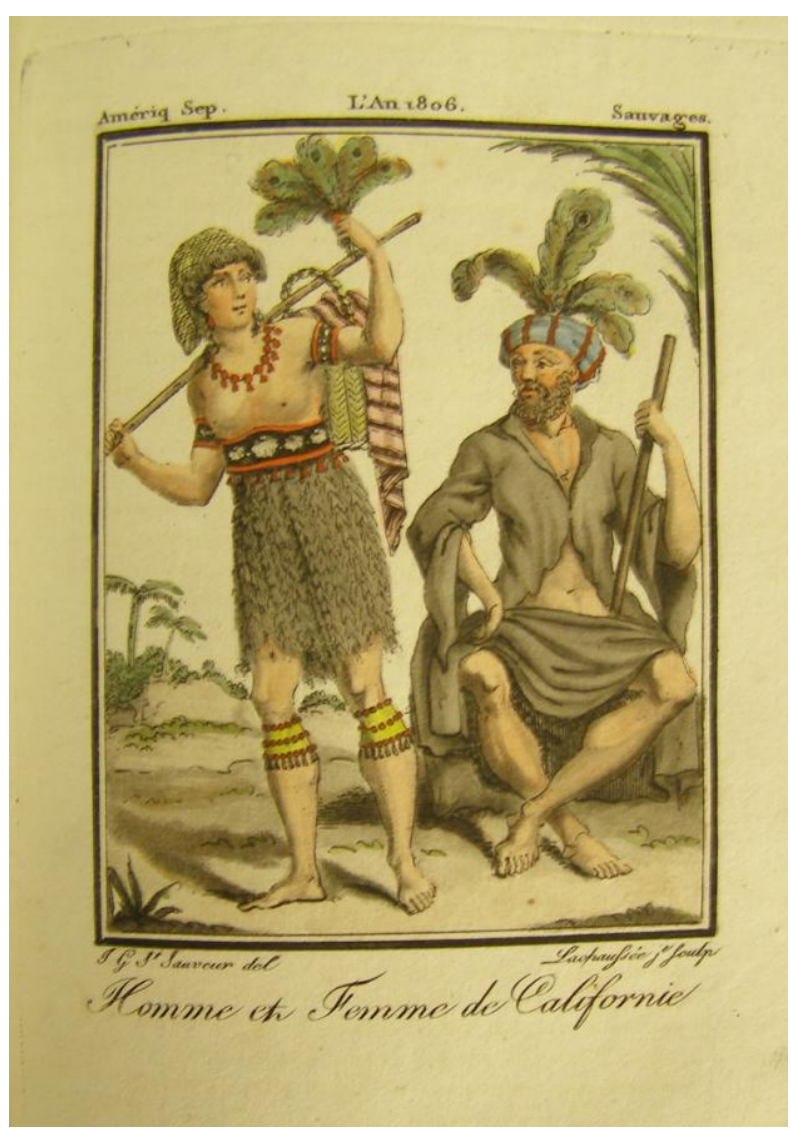

Fig 100 


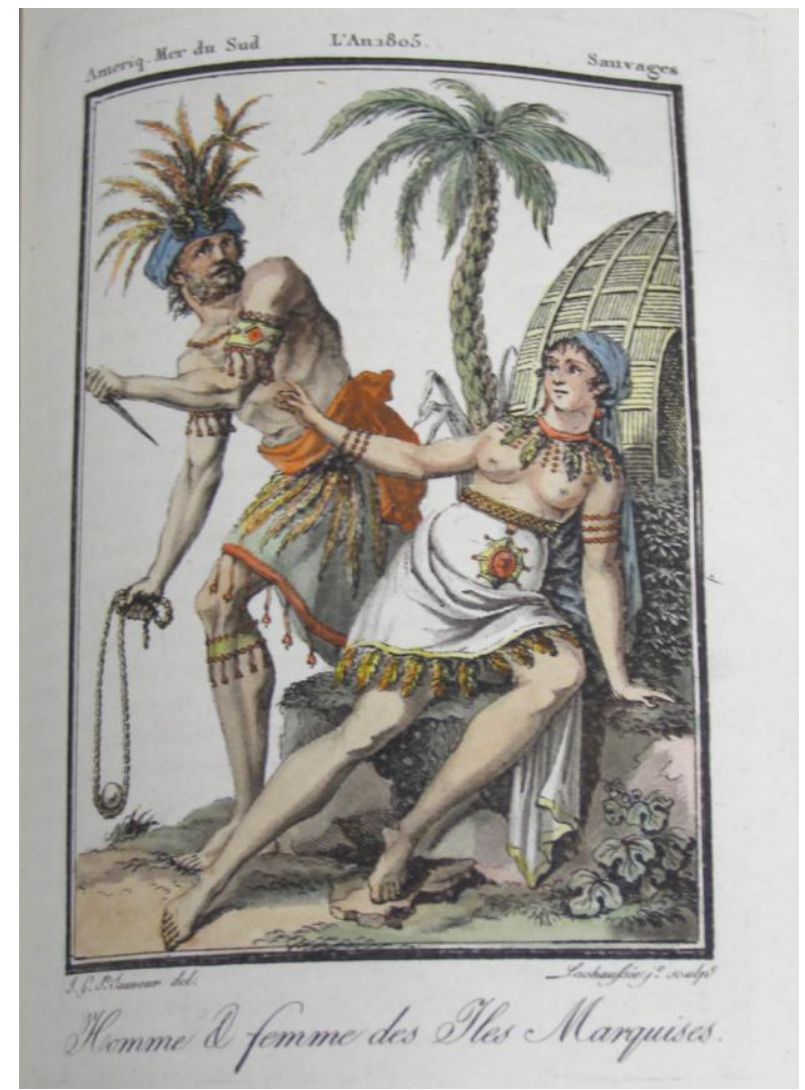

Fig 101

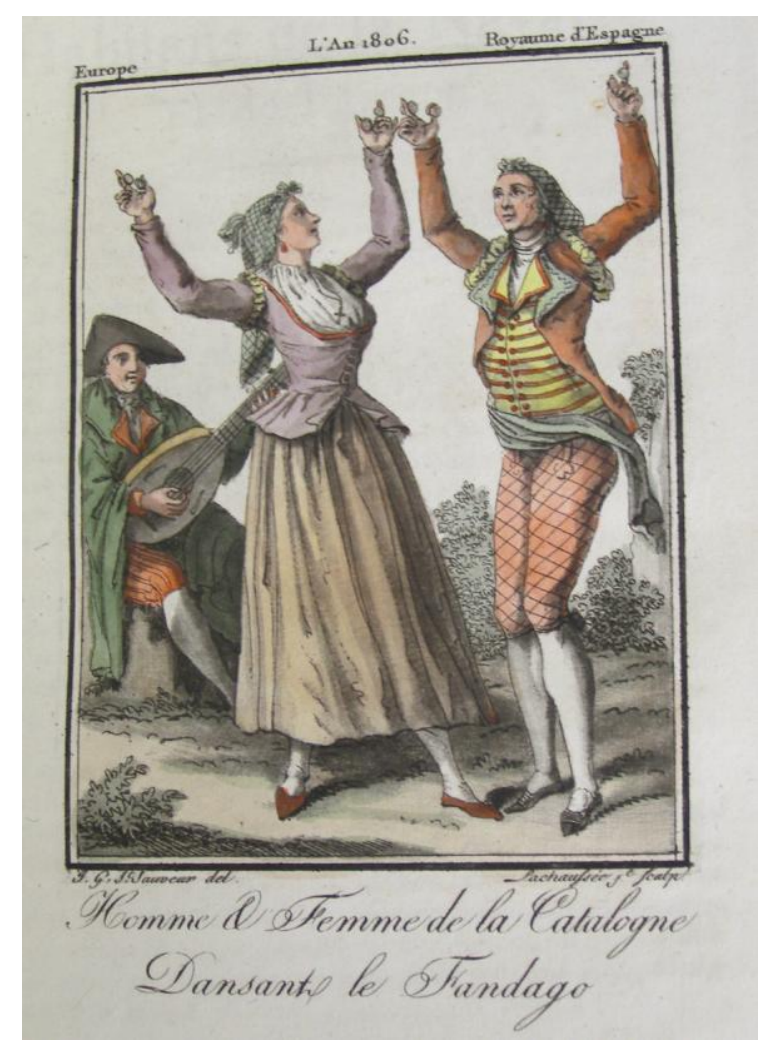

Fig 102 


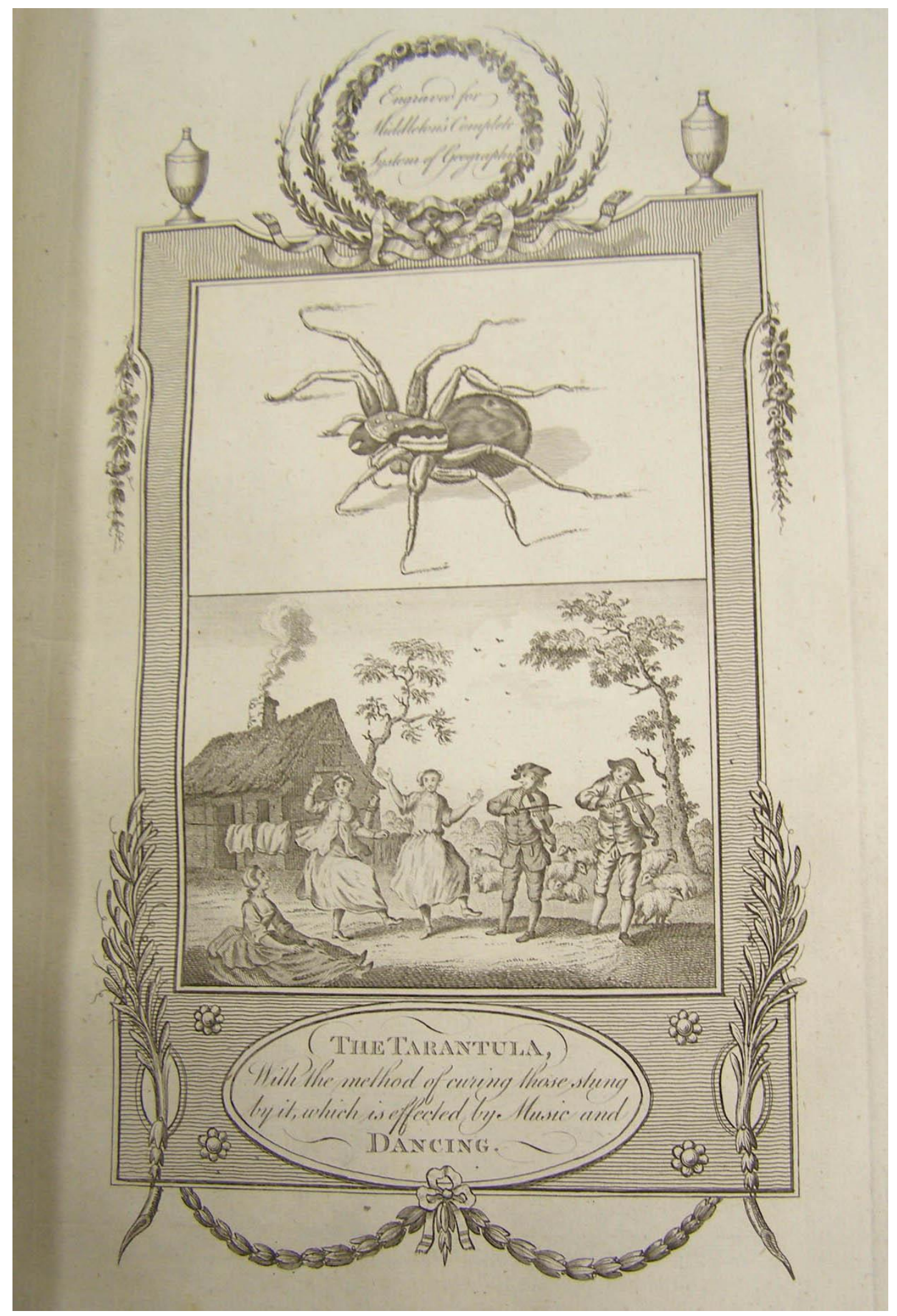

Fig 103 


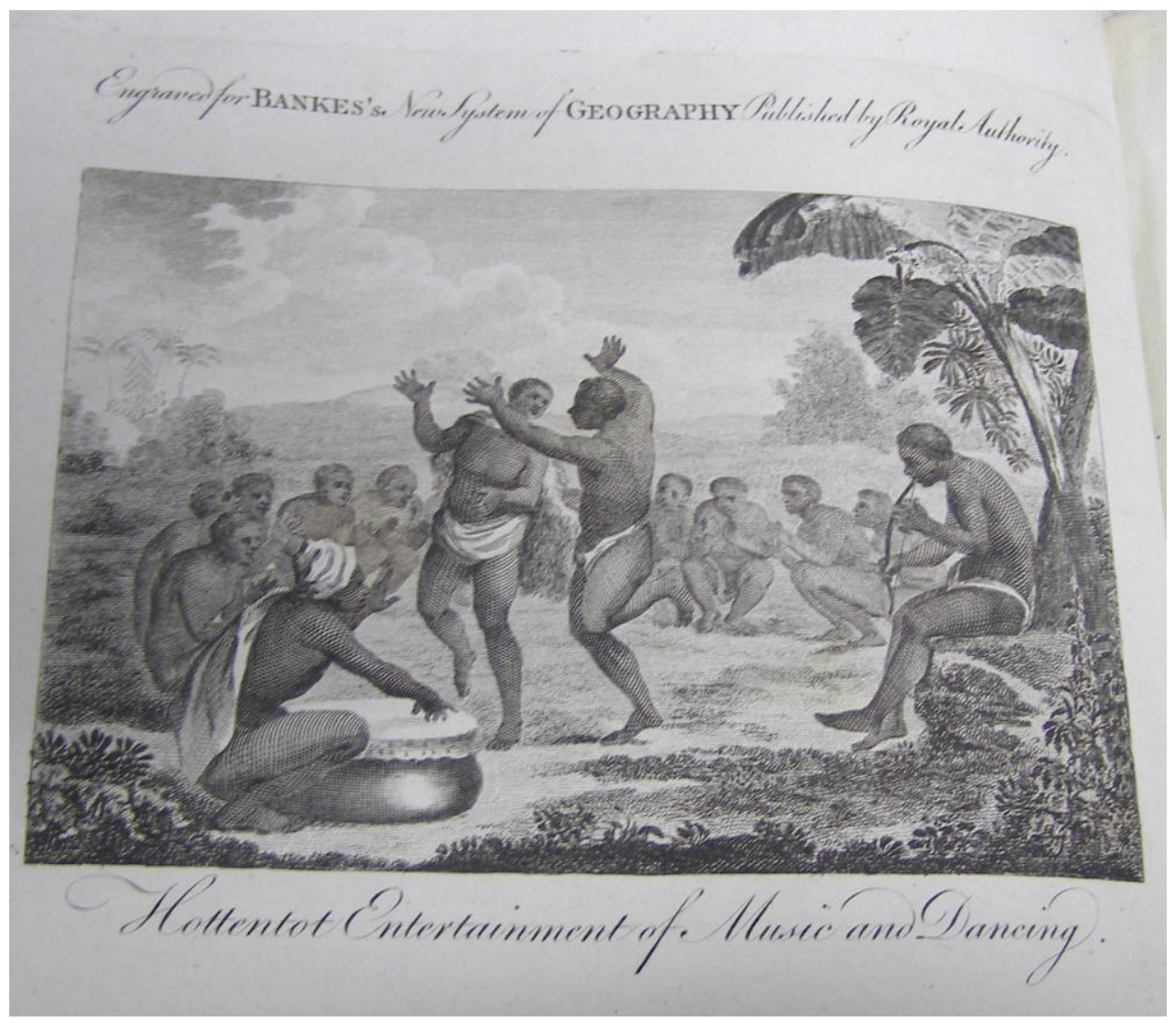

Fig 104

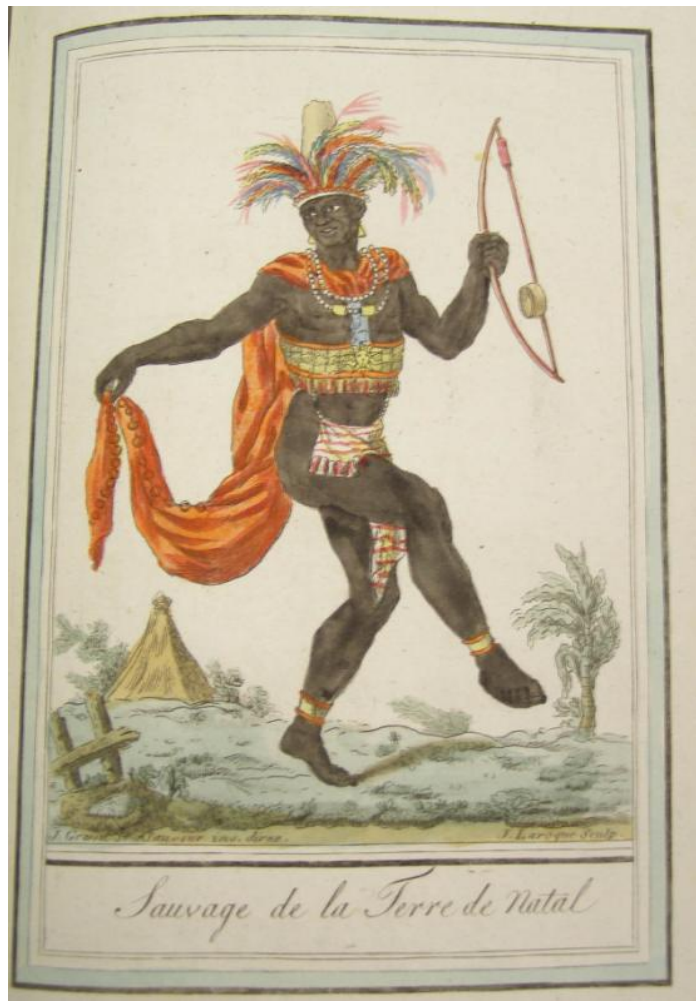

Fig 105 


\section{Bibliography}

\section{Primary sources}

Austen, Jane, [1813] Pride and prejudice, Oxford: Oxford University Press, 1957.

Bankes, Thomas, Rev., with Blake, E., Cook, A. and Lloyd T, New, royal and authentic system of universal geography ... Europe, Asia, Africa and America ... [and] collection of voyages and travels, London: C. Cooke, 17 Paternoster Row; 1790, ATL.

Burke, Edmund, [1757] A philosophical enquiry into the origin of our ideas of the sublime and beautiful, $2^{\text {nd }}$ ed. 1759, Eighteenth-century collections online, VUW library, accessed 12 October 2009.

A collection of the dresses of different nations, antient and modern. Particularly old English dresses, 4 vols, London: Thomas Jefferys, 1757-72, Eighteenth-century collections online, VUW library, accessed 4 September 2008 and 20 April 2009.

Commerson, Philibert, Mercure de France, November 1769, Geneva: Slatkine Reprints, 1968, vol. 97.

Cornu, Jean Francois [and Grasset de Saint-Sauveur, Jacques], Moeurs, loix et costumes des sauvages de la Nouvelle Zélande et de la Baye Hudson, accompagnés de six figures dessinees caractéristiquement représentant les costumes, gravées avec soin \& peintes dans les couleurs adoptées par chaque nation, toutes ornées de filets d'or, \&c. (Part of Grasset \& Maréchal's La Mythologie ... de tous le Monde, 12 vols) Paris? 1793? ATL.

Fordyce, James, Rev., Sermons to young women, (a new edition), 2 vols, 1775, Eighteenthcentury collections online, VUW library, accessed 21 August 2008.

Forster, Johann Reinhold, [1778] Observations made during a voyage round the world, Nicholas Thomas, Harriet Guest, and Michael Dettelbach (eds), Honolulu: University of Hawai'i Press, 1996.

La Géographie en estampes ou moeurs et costumes des différens peuples de la terre, Paris: chez Lecerf, graveur, et $\mathrm{P}^{\mathrm{re}}$ Blanchard, 1825, ATL.

Grasset de Saint-Sauveur, Jacques, Moeurs, usages et costumes d'Otahiti ou Taiti, Moeurs et coutumes des habitans des Isles Maquises, Moeurs, usages, lois et costumes des habitans de Sainte-Christine, Paris: 1784, ATL.

Grasset de Saint-Sauveur, Jacques, Moeurs et costumes des insulaires Nouvelle Zélande, (1788 text?) 1796 (plates), NLA, Rex Nan Kivell collection.

Grasset de Saint-Sauveur, Jacques, Encyclopédie des voyages: contenant l'abrégé historique des mours, usages, habitudes domestiques, religions, fêtes, supplices, funérailles, sciences, arts, et commerce de tous les peuples : et la collection complette de leurs habillemens civils, militaires, religieux et dignitaires, dessinés d'après nature, gravés avec soin et coloriés à l'aquarelle, 4 vols, 1795, State Library of New South Wales, Sydney. 
Grasset de Saint-Sauveur, Jacques, Encyclopédie des voyages: contenant l'abrégé historique des moeurs, usages, habitudes domestiques, religions, fêtes supplices, funérailles, sciences, arts, et commerce de tous les peuples: et la collection complette de leurs habillemens civils, militaires, religieux et dignitaires, dessines d'après nature, graves avec soin et colories a l'aquarelle. 432 coloured plates. 5 vols, Paris: se trouve chez l'Auteur, rue Nicaise, maison de la Section des Tuileries; chez Deroy, libraire, rue du Cimitière-Andre no. 15; et chez les principaux libraires de la République, 1796, ATL.

Grasset de Saint-Sauveur, Jacques, Dresses of the representatives of the people, members of the two councils, and of the executive directory... Printed for E \& S Harding, Pall-Mall, London, 1796, translated from 1795 French edition, Eighteenth-century collections online, VUW library, accessed 4 June 2008.

Grasset de Saint-Sauveur, Jacques, Histoire abrégée des découvertes des Capitaines Cook, Wilson, La Pérouse, etc. etc. ... accompagnée d'un tableau représentant les diffèrens peuples de cette partie du monde, chacun dans le costume et l'attitude qui lui et propre ... Paris and Bordeaux: chez l'Auteur ...et les principaux libraries, 1798/99 (Year 7), State Library of New South Wales, Sydney. (This is the booklet which accompanied the tableau print of the Discoveries of Cook and La Pérouse.)

Grasset de Saint-Sauveur, Jacques, Voyages pittoresques dans les quatre parties du monde, ou troisième édition de l'encyclopédie des voyages: contenant les costumes des principaux peuples de l'Europe, de l'Asie, de l'Afrique, de l'Amérique et des sauvages de la mer du sud, gravés et coloriés avec soin ... 2 vols, Paris: chez Madame veuve Hocquart, 1806, ATL.

Hogarth, William, Analysis of beauty, 1753, London, Eighteenth-century collections online, VUW library, accessed 5 August 2009.

Lery, Jean de, History of a voyage to the land of Brazil (1580)... translated by Janet Whatley, University of California Press, ACLS Humanities e-book, VUW library.

Maréchal, P. Sylvain [and Jacques Grasset de Saint-Sauveur] Moeurs et costumes des habitans de l'Isle Taiti, from Costumes civils actuels de tous les peuples connus, dessinés d'après nature, gravés et coloriés ... Paris: chez Pavard, 1788, ATL. Copy also contains the frontispiece for 'Amérique'. Complete copy (4 vols) of Costumes civils ... on microfilm at NLA.

Middleton, Charles, A new and complete system of geography containing a full, accurate, authentic and interesting account and description of Europe, Asia, Africa and America ... including the essence of all the most remarkable voyages and travels ..., 2 vols, London: J. Cooke, 17 Paternoster Row, 1777, ATL.

Millar, George, The new and universal system of geography: being a complete history and description of the whole world ..., London: Alexander Hogg, 16 Paternoster Row, 1782, ATL.

Montesquieu, Baron de, [1721] The Persian letters, edited, translated and introduced by J. Robert Loy, New York: Meridian Books, 1961. 
Moore, John, A new and complete collection of voyages and travels ... describing, in the most accurate manner, every place worthy of notice in Europe, Asia, Africa, and America, 2 vols, London: Alexander Hogg, 1790, ATL.

New discoveries concerning the world and its inhabitants, 2 vols, London, 1778, ATL.

Picart, Bernard, The ceremonies and religious customs of the various nations of the known world: together with historical annotations, and several curious discourse s equally instructive and entertaining. Written originally in French and illustrated by Mr Bernard Picart, translated into English by a gentleman, 7 vols, London 1733-39, Eighteenthcentury collections online, VUW library, accessed 1 July 2009.

Richardson, Jonathan, An essay on the theory of painting, London, 1715, Eighteenthcentury collections online, VUW library, accessed 16 August 2008.

Rickman, John, Journal of Captain Cook's last voyage to the Pacific Ocean, on Discovery; performed in the years 1776, 1777, 1778, 1779, illustrated with cuts, and a chart, shewing the tracts of the ships employed in this expedition, London: Printed for E. Newbery, 1781, ATL.

Rousseau, Jean-Jacques, The basic political writings ... discourse on the origins of inequality, [1755] translated and edited by Donald Cress, Indianapolis \& Cambridge:

Hackett Publishing, 1987.

Shelvocke, George, A voyage around the world by way of the great South Sea... London, 1726, Eighteenth-century collections online, VUW library, accessed 8 July 2009.

Stuart, Martinus and Kuypers, Jacques, De mensch, zoo als hij voorkomt op den bekenden aardbol, 6 vols, Amsterdam: Johannes Allart, 1802-1807, ATL.

Vecellio, Cesare, [1590] Vecellio's Renaissance costume book, New York: Dover Publications, 1977.

Winckelmann, Johann Joachim, [1766] Writings on art, David Irwin (ed), London: Phaidon, 1972.

\section{Secondary sources}

Alpers, Svetlana and Baxandall, Michael, Tiepolo and the pictorial intelligence, New Haven \& London: Yale University Press, 1994.

Art Gallery New South Wales and National Gallery of Australia, Les sauvages de la mer pacifique: manufactured by Joseph Dufour et cie 1804-05 after a design by Jean-Gabriel Charvet, Sydney \& Canberra: AGNSW \& NGA, 2000.

Ashton, Mark, 'Allegory, fact, and meaning in Giambattista Tiepolo's four continents in Würzburg', The art bulletin, 60(1), March 1978, pp. 109-125. 
Bassani, Ezio and Tedeschi, Letizia, 'The image of the Hottentot in the seventeenth and eighteenth centuries', Journal of the history of collections, 2(2), pp. 157-86.

Benedict, Barbara M, Curiosity: a cultural history of early modern inquiry, Chicago \& London: Chicago University Press, 2001.

Bewell, Alan, 'Constructed places, constructed peoples: charting the improvement of the female body in the Pacific', in Jonathan Lamb, Robert Maccubbin and David Morrill (eds), 'The South Pacific in the eighteenth century: narratives and myths. Papers from the ninth David Nicol Smith memorial seminar', Eighteenth-century life, 18(3), Nov 1994, pp. 3754.

Bradshaw, Lael Ely, 'Ephraim Chambers' Cyclopaedia' in Frank Kafker (ed), 'Notable encyclopedias of the seventeenth and eighteenth centuries: nine predecessors of the Encyclopédie', Studies in Voltaire and the eighteenth century, 194, 1981, pp. 123-140.

Bravo, Michael, 'Precision and curiosity in scientific travel: James Rennell and the orientalist geography of the new imperial age (1760-1830)', in Jas Elsner and Joan-Pau Rubiés (eds), Voyages and visions: towards a cultural history of travel, London: Reaktion Books, 1999, pp. 162-183.

Bucher, Bernadette, Icon and conquest: a structural analysis of the illustrations of de Bry's great voyages, translated by Basia Miller Gulati, Chicago: Chicago University Press, 1981.

Burke, John, 'The wild man's pedigree: scientific method and racial anthropology', in Edward Dudley and Maximillian Novak (eds), The wild man within: an image in Western thought from the Renaissance to Romanticism, Pittsburgh: University of Pittsburgh Press, 1972, pp. 259-280.

Célestin, Roger, From cannibals to radicals: figures and limits of exoticism, Minneapolis \& London: University of Minnesota Press, 1996.

Cohen, Sarah, Art, dance and the body in French culture of the Ancien Regime, Cambridge: Cambridge University Press, 2000.

Cohen, William, The French encounter with Africans: white response to blacks, 1530 1880, Bloomington \& London: Indiana University Press, 1980.

Collins, Roger, 'Jacques Grasset de Saint-Sauveur', Turnbull Library Record, 17(1), May 1984, pp. 28-41.

Collins, Roger, 'An inside story: Dufour and Charvet's wallpaper of the South Seas', Bulletin of New Zealand art history, 9, 1985, pp. 5-13.

Cosgrove, Denis, Apollo's eye: a cartographic genealogy of the earth in the Western imagination, Baltimore \& London: The Johns Hopkins University Press, 2001.

Culpin, David J. 'The exotic and the creative imagination in the 1690s: Charles Perrault's Les hommes illustres', Eighteenth-century life, 26(3), Fall 2002, pp. 31-44. 
Currie, Noel Elizabeth, Constructing colonial discourse: Captain Cook at Nootka Sound, 1778, Montreal: McGill-Queen's University Press, 2005.

Darnton, Robert, 'Philosophers trim the tree of knowledge: the epistemological strategy of the Encyclopédie' in The great cat massacre and other episodes in French cultural history, London: Penguin, 1984, pp. 188-208.

Daston, Lorraine and Park, Katharine, Wonders and the order of nature 1150-1750, New York: Zone Books, 2001.

De Baecque, Antoine, 'The allegorical image of France 1750-1800: a political crisis of representation', Representations, 47, Summer 1994, pp. 111-143.

Dickason, Olive P., The myth of the savage and the beginnings of French colonialism in the Americas, Edmonton: University of Alberta Press, 1984.

Dobie, Madeleine, Foreign bodies: gender, language, and culture in French orientalism, Stanford: Stanford University Press, 2001.

Downes, Alan, 'The bibliographic dinosaurs of Georgian geography (1714-1830)', The geographical journal, 137(3), Sept 1971, pp.379-387.

D'un regard l'autre: histoire des regards européens sur l'Afrique, l'Amérique et l'Océanie, Paris: Musée du Quai Branly, exhibition catalogue under the direction of Yves Le Fur, 2006.

Edmond, Rod, Representing the South Pacific: colonial discourse from Cook to Gauguin, Cambridge: Cambridge University Press, 1997.

Ellingson, Ter, The myth of the noble savage, Berkeley \& London: University of California Press, 2001.

Elliott, Jane, 'The choosers or the dispossessed? Aspects of the work of some French eighteenth century Pacific explorers', in Annick Foucrier (ed), The French and the Pacific world, $17^{\text {th }} 19^{\text {th }}$ centuries, Aldershot \& Burlington: Ashgate, 2005.

Fullagar, Katharine, 'Savages and moderns: the new world in Britain, 1710-c1800', PhD thesis, University of California, Berkeley, 2004, ProQuest Dissertations and Theses, partial access, VUW library, accessed 24 May 2008.

Garofalo, Silvano, 'Gianfrancesco Pivati’s Nuovo dizionario', in Frank Kafker (ed), 'Notable encyclopedias of the seventeenth and eighteenth centuries: nine predecessors of the Encyclopédie', Studies in Voltaire and the eighteenth century, 194, 1981, pp. 197-219.

Garrioch, David, 'Reading in eighteenth-century Paris' in The culture of the book: essays from two hemispheres in honour of Wallace Kirsop, Melbourne: Bibliographical Society of Australia and New Zealand, 1999, pp. 288-299.

Gaudio, Michael, Engraving the savage: the new world and techniques of civilization, Minneapolis: University of Minnesota, 2008. 
Griffiths, Antony, Prints for books: book illustration in France, 1760-1800, Panizzi lectures 2003, London: The British Library, 2004.

Guest, Harriet, 'The great distinction: figures of the exotic in the work of William Hodges', Oxford art journal, 12(2), 1989, pp. 36-58.

Guest, Harriet, Empire, barbarism, and civilisation: James Cook, William Hodges, and the return to the Pacific, Cambridge: Cambridge University Press, 2007.

Hamell, George, (1989) 'Mohawks abroad: the 1764 Amsterdam etching of Sychnecta' in Christian Feest (ed), Indians and Europe: an interdisciplinary collection of essays, $2^{\text {nd }}$ ed., Lincoln \& London: University of Nebraska Press, 1999, pp. 175-191.

Harrison, Peter, 'Curiosity, forbidden knowledge, and the reformation of natural philosophy in early modern England', Isis, 92(2), June 2001, pp. 265-290.

Hiler, Hilaire and Hiler, Meyer, [1939], Bibliography of costume; a dictionary catalog of about eight thousand books and periodicals, Adah V. Morris (ed), New York: B. Blom, 1967 (reprinted).

Honour, Hugh, The new golden land: European images of America from the discoveries to the present time, New York: Pantheon Books, 1975.

Hudson, Nicholas, "From "nation" to "race": the origin of racial classification in eighteenth-century thought', Eighteenth-century studies, 29(3), 1996, pp. 247-264.

Hulme, Peter and Jordanova, Ludmilla (eds), The Enlightenment and its shadows, London \& NY: Routledge, 1990.

Hunt, Margaret 'Racism, imperialism, and the traveler's gaze in eighteenth-century England', The Journal of British studies, 32(4), October 1993, pp. 333-357.

Jacques, T. Carlos, 'From savages and barbarians to primitives: Africa, social typologies, and history in eighteenth-century French philosophy', History and theory, 36(2), May 1997, pp. 190-215.

Jaenen, Cornelius, "Les sauvages Ameriquains": persistence into the $18^{\text {th }}$ century of traditional French concepts and constructs for comprehending Amerindians', Ethnohistory, 29(1), 1982, pp. 43-56.

Joppien, Rüdiger, 'The artistic bequest of Captain Cook's voyages: popular imagery in European costume books of the late eighteenth and early nineteenth centuries', in Robin Fisher \& Hugh Johnston (eds), Captain Cook and his times, Vancouver \& London: Douglas \& McIntyre/ Croom Helm, 1979, pp. 187-210.

Joppien, Rüdiger and Smith, Bernard, The art of Captain Cook's voyages, Melbourne: Oxford University Press, 1985-7 [Vol 1 - The voyage of the Endeavour; Vol 2 - The voyage of the Resolution and Adventure, Vol 3 Catalogue - The voyage of the Resolution 
and Discovery, 1776-1780; Vol 3 - Text - The voyage of the Resolution and Discovery, 1776-1780.]

Joubin, Rebecca, 'Islam and Arabs through the eyes of the Encyclopédie: the "other" as a case of French cultural self-criticism', International journal of Middle East studies, 32, 2000, pp. 197-217.

Kahn, Miriam, 'Tahiti intertwined: ancestral land, tourist postcard, and nuclear test site', American anthropologist, new series, 102(1), March 2000, pp. 7-26.

Kenny, Neil, The uses of curiosity in early modern France and Germany, Oxford \& NY: Oxford University Press, 2004.

Kenny, Neil, 'The metaphorical collecting of curiosities in early modern France and Germany', in R. J. W. Evans and Alexander Marr (eds), Curiosity and wonder from the Renaissance to the Enlightenment, Aldershot \& Burlington: Ashgate, 2006, pp. 43-62.

Knellwolf, Christa, 'The exotic frontier of the imperial imagination', Eighteenth-century life, 26(3), Fall 2002, pp.10-30.

Knellwolf, Christa and McCalman, Iain, 'Introduction', Eighteenth-century life, 26(3), Fall 2002, pp. 1-9.

Le Corbeiller, Clare, 'Miss America and her sisters: personifications of the four parts of the world', The Metropolitan Museum of Art Bulletin, 19(8), April 1961, pp. 209-223.

Liebersohn, Harry, The travelers' world: Europe to the Pacific, Cambridge, Mass. \& London: Harvard University Press, 2006.

Lovejoy, Arthur and Boas, George [1935] Primitivism and related ideas in antiquity, New York: Octagon Books, 1965.

McClung Fleming, E., 'The American image as Indian princess 1765-1783', Winterthur portfolio, 2, 1965, pp. 65-81.

MacKenzie, John, Orientalism: history, theory and the arts, Manchester \& NY: Manchester University Press, 1995.

Mansel, Philip, Dressed to rule: royal and court costume from Louis XIV to Elizabeth II, New Haven \& London: Yale University Press, 2005.

Marshall, Peter J. and Williams, Glyndwr, The great map of mankind: British perceptions of the world in the age of Enlightenment, London, Melbourne \& Toronto: J M Dent \& Sons, 1982.

Mason, Peter, 'From presentation to representation: Americana in Europe', Journal of the history of collections, 6(1), 1994, pp. 1-20.

Mason, Peter, Infelicities: representations of the exotic, Baltimore \& London: Johns Hopkins University Press, 1998. 
Mason, Peter, 'Ethnographic portraiture in the eighteenth century: George Psalmanaazaar's drawings of Formosans', Eighteenth-century life, 23(3), 1999, pp. 58-76.

Mayor, Hyatt A, 'Renaissance costume books', Bulletin of the Metropolitan Museum of Art, 37(6), June 1942, pp. 158-9.

Meglin, Joellen, 'Sauvages, sex roles, and semiotics: representations of Native Americans in the French ballet, 1736-1837, part one: the eighteenth century', Dance chronicle, 23(2), 2000, pp. 87-132.

Miller, Arnold, 'Louis Moréri's grand dictionnaire historique', in Frank Kafker (ed) 'Notable Encyclopedias of the Seventeenth and Eighteenth Centuries: Nine Predecessors of the Encyclopédie', Studies in Voltaire and the eighteenth century, 194, 1981, pp. 13-47.

National Library of Australia, Paradise possessed: the Rex Nan Kivell collection, Canberra: NLA, 1998.

Nochlin, Linda, The politics of vision: essays on nineteenth century art and society, London: Thames and Hudson, 1991.

Nouvel-Kammerer, Odile, [1994] 'Wide horizons: French scenic papers', in Lesley Hoskins (ed), The papered wall: history, pattern, technique, $2^{\text {nd }}$ ed., New York: Thames \& Hudson, 2005.

Pagden, Anthony, European encounters with the new world: from Renaissance to Romanticism, New Haven \& London: Yale University Press, 1993.

Pocock, J. G. A. (John Greville Agard), 'Nature and history; self and other: European perceptions of world history in the age of encounter' in Alex Calder, Jonathan Lamb and Bridget Orr (eds), Voyages and beaches: Pacific encounters, 1769-1840, Honolulu: University of Hawai'i Press, 1999 (Essays originated as papers to the $9^{\text {th }}$ David Nichol Smith Memorial Seminar, 1993.)

Portalis, Roger, Les dessinateurs d'illustrations au dix-huitième siècle, 2 vols, Paris: Morgand \& Fatout, 1877.

Ribeiro, Aileen, Dress in eighteenth-century Europe, New Haven \& London: Yale University Press, 2002.

Robb, Graham, The discovery of France, London: Picador, 2007.

Roche, Daniel, [1989] The culture of clothing: dress and fashion in the Ancien Regime, Cambridge: Cambridge University Press, translated by Jean Birrell, 1994.

Rousseau, George and Porter, Roy (eds), Exoticism in the Enlightenment, Manchester: Manchester University Press, 1990.

Rubiés, Joan-Pau, 'Instructions for travellers: teaching the eye to see', History and anthropology, 9(2-3), pp. 139-190. 
Ryan, Tom, "'Les president des terres Australes": Charles de Brosses and the French Enlightenment beginnings of Oceanic anthropology', The journal of Pacific history, 37(2) September 2002, pp. 157-186.

Said, Edward, Orientalism, New York: Vintage Books, 1978.

Salmond, Anne, Aphrodite's island: the European discovery of Tahiti, NZ: Penguin / Viking, 2009.

Shannon, Timothy J., 'Dressing for success on the Mohawk frontier: Hendrick, William Johnson, and the Indian fashion' The William and Mary quarterly, $3^{\text {rd }}$ series, 53(1), January 1996, pp. 13-42.

Shapiro, H. A. (Harvey Alan), Personifications in Greek art, Zurich: Akanthus, 1993.

Smith, Bernard, European vision and the South Pacific 1768-1850: a study in the history of art and ideas, London, Oxford, NY: Oxford University Press, 1960.

Smith, Bernard, 'Cook's posthumous reputation', in Robin Fisher and Hugh Johnston (eds), Captain Cook and his times, Vancouver \& London: Douglas \& McIntyre/ Croom Helm, 1979.

Smith, Bernard, European vision and the South Pacific, New Haven \& London: Yale University Press, $2^{\text {nd }}$ ed., 1984.

Smith, Bernard, Imagining the Pacific: in the wake of the Cook voyages, Melbourne: Melbourne University Press at the Miegunyah Press, 1992.

Stagl, Justin, A history of curiosity: the theory of travel 1550-1800, Chur, Switzerland: Harwood Academic Publishers, 1995.

Stein, Perrin 'Amédée Van Loo's costume turc: the French sultana', The art bulletin, 78(3), Sept. 1996, pp. 417-438.

Stein, Perrin, 'Exoticism as metaphor: turquerie in eighteenth-century French art', $\mathrm{PhD}$ thesis, New York University, 1997.

Strong, Roy, Gloriana: the portraits of Queen Elizabeth I, London: Pimlico, 2003.

Terry, Martin, 'The voyages of Captain Cook: a Pacific theme in French decorative arts', The French-Australian cultural connection: papers from a symposium held at the University of New South Wales, 16-17 September 1983, School of French, University of NSW and CEEFA, 1984.

Thomas, Nicholas, 'Discovering voyages: researching the Rex Nan Kivell collection', in National Library of Australia, Paradise Possessed: the Rex Nan Kivell collection, Canberra: NLA, 1998, pp. 59-64. 
Thomas, Nicholas, 'Licensed curiosity: Cook's Pacific voyages', in John Elsner and Roger Cardinal (eds), The cultures of collecting, Melbourne \& London: Melbourne University Press, 1994, pp. 116-136.

Thomas, Nicholas, Cole, Anna and Douglas, Bronwen (eds), Tattoo: bodies, art and exchange in the Pacific and the West, London: Reaktion Books, 2005.

Todorov, Tzvetan, On human diversity: nationalism, racism, and exoticism in French thought, translated by Catherine Porter, Cambridge, Mass \& London: Harvard University Press, 1993.

Withers, Charles, 'Encyclopaedism, modernism and the classification of geographical knowledge', Transactions of the Institute of British Geographers, new series 21(1), 1996, pp. 275-298.

Womack, William, 'Guillaume Raynal and the eighteenth-century cult of the noble savage', Bulletin of the Rocky Mountain Modern Language Association, 26(3), Autumn 1972, pp. 98-107.

Yeo, Richard, Encyclopaedic visions: scientific dictionaries and Enlightenment culture, Cambridge: Cambridge University Press, 2001. 